Karine Zuccolan Carvas

\title{
DIQUES MESOZOICOS SUBALCALINOS DE BAIXO TITÂNIO DA REGIÃO DOS LAGOS (RJ): GEOQUÍMICA E GEOCRONOLOGIA ${ }^{40} \mathrm{Ar} /{ }^{39} \mathrm{Ar}$
}

Instituto de Astronomia, Geofísica e Ciências Atmosféricas

Universidade de São Paulo

São Paulo

$-2016-$ 
Karine Zuccolan Carvas

\section{Diques mesozoicos subalcalinos de baixo titânio da} Região dos Lagos (RJ): geoquímica e geocronologia ${ }^{40} \mathrm{Ar} /{ }^{39} \mathrm{Ar}$

Dissertação apresentada ao Departamento de Geofísica do Instituto de Astronomia, Geofísica e Ciências Atmosféricas da Universidade de São Paulo como requisito parcial para obtenção do título de Mestre em Ciências.

Versão corrigida. O original encontra-se disponível na Unidade.

Área de concentração: Geofísica

Orientadora: Prof. a Dr. a Leila Soares Marques

São Paulo

$-2016-$ 
À minha avó paterna, Maria Rosa, e ao meu avô materno, Antônio Zuccolan, guerreiros que, no alto de seus oitenta e alguns anos, apadrinham os momentos mais definitivos deste trabalho. 


\section{RESUMO}

Os diques da Região dos Lagos, localizados entre os municípios de Arraial do Cabo, Cabo Frio e Armação dos Búzios (RJ), integram o Enxame de Diques da Serra do Mar (ESM) e apresentam particularidades geoquímicas e geocronológicas que fazem com que seu papel na abertura do Atlântico Sul ainda seja pouco compreendido. Este estudo apresenta os resultados da investigação detalhada sobre a gênese e a idade dessas intrusões, através novas análises de elementos maiores, menores, traços, razões isotópicas ( $\mathrm{Sr}, \mathrm{Nd}$ e $\mathrm{Pb}$ ) e datações ${ }^{40} \mathrm{Ar} /{ }^{39} \mathrm{Ar}$.

Os diques são quimicamente representados por basaltos toleíticos, andesibasaltos toleíticos e basaltos transicionais, com teores de $\mathrm{TiO}_{2}$, em sua maioria, inferiores a $2 \%(\mathrm{BTi})$. Os dados de geoquímica elemental permitem identificar dois grupos, um mais primitivo e empobrecido em elementos incompatíveis (grupo A), e outro mais evoluído e enriquecido nesses elementos (grupo B). Os dados sugerem pouca ou nenhuma influência de contaminação crustal durante a evolução e apontam semelhanças do grupo A com os basaltos BTi (Esmeralda) da Província Magmática do Paraná (PMP). O grupo B, por sua vez, apresenta características distintas dos derrames BTi da PMP. O grupo A possui composições isotópicas pouco radiogênicas em Sr e mais radiogênicas em $\mathrm{Pb}$ que o grupo $\mathrm{B}$, assemelhando-se àquelas dos diques Horingbaai da Namíbia. As razões isotópicas de $\mathrm{Pb}$ sugerem que os dois grupos foram originados por fontes mantélicas distintas, as quais são também menos radiogênicas que os derrames BTi da PMP. Os dados não se adequam à diferenciação por cristalização fracionada com assimilação concomitante ou por mistura envolvendo os reservatórios mantélicos clássicos. Este comportamento pode estar relacionado a heterogeneidades do manto litosférico, causadas por longos processos de subducção durante a amalgamação do Gondwana ocidental.

As análises ${ }^{40} \mathrm{Ar} /{ }^{39} \mathrm{Ar}$ mostram que a presença de sericitização e albitização nos plagioclásios pode imprimir as idades desses processos nos espectros. Plagioclásios sericitizados do grupo A forneceram idades de 106-108 Ma, e também um provável evento de albitização em 96 Ma. Tais idades discordam tanto das de plagioclásios frescos (idades máximas de 125-140 Ma), afetados por excesso de Ar em decorrência de 
inclusões de piroxênio e apatita, como daquelas de 132 Ma obtidas em anfibólio-biotita. Estas últimas devem marcar a intrusão dos diques do grupo $A$, confirmando sua associação com a PMP. A análise em rocha total de um dique do grupo B apresentou idade máxima de cerca de $108 \mathrm{Ma}$, sugerindo que a intrusão dos grupos A e B podem não ser contemporâneas. A similaridade entre a idade do grupo B e aquela de soerguimento da costa sudeste sugere que estes diques possam ter sido originados durante esse evento, que também teria causado a alteração (sericitização) dos plagioclásios do grupo $A$.

PALAVRAS CHAVE: Enxame da Serra do Mar, Província Magmática do Paraná, Magmatismo toleítico da Região dos Lagos, Enxames de Diques Máficos 


\section{ABSTRACT}

The Região dos Lagos tholeiitic dykes, located in Rio de Janeiro State, encompass the Arraial do Cabo, Cabo Frio and Armação de Búzios towns and integrate the Serra do Mar Dyke Swarm. Their role in the South Atlantic opening processes is still poorly defined because of their peculiar geochemical and geochronological features. In this work, the petrogenesis and the geochronology of these intrusions were investigated in detail based on new data of elemental (major, minor and trace elements) and isotope ( $\mathrm{Sr}, \mathrm{Nd}$ and $\mathrm{Pb}$ ) geochemistry along with a careful ${ }^{40} \mathrm{Ar} /{ }^{39} \mathrm{Ar}$ dating.

The dykes are chemically represented by tholeiitic basalts, andesi tholeiitic basalts and transitional basalts, usually presenting $\mathrm{TiO}_{2}$ contents lower than $2 \%$ (LTi). The elemental geochemistry allows the recognition of two magmatic groups; one of them is more primitive and depleted in incompatible elements (group A), whereas the other one is more evolved and enriched in these elements (group B). The data also indicate that crustal assimilation, if existed, had a small role in the magmatic evolution of both groups, and point out similarities between group A and the LTi flows (Esmeralda) from the Paraná Magmatic Province (PMP). Group B, in turn, displays geochemical features very different from those of the LTi basalts from PMP.

The Sr isotope compositions of group $A$ are less radiogenic than those of the $B$ one, but the opposite occurs with $\mathrm{Pb}$, which makes the first group similar to the Horingbaai dykes from Namibia. The $\mathrm{Pb}$ isotope ratios indicate that $\mathrm{A}$ and $\mathrm{B}$ were originated from distinct mantle sources, which also differ from those related to PMP LTi flows. The isotope data are not compatible with assimilation-fractional crystallization processes or simple mixtures involving the classic mantle reservoirs. This behavior suggests origin in heterogeneous lithospheric subcontinental mantle, probably affected by long subduction periods during Western Gondwana amalgamation.

The ${ }^{40} \mathrm{Ar} /{ }^{39} \mathrm{Ar}$ geochronological data point out that the presence of plagioclase sericitization and albitization in their rims may imprint the age of these events in the age spectra. Sericitized plagioclase grains of group A displayed ages of 106-108 Ma, while the albitized fractions provided ages of $96 \mathrm{Ma}$. Such results disagree with both the fresh plagioclase grains (maximum ages of $125-140 \mathrm{Ma}$ ), very affected by excess Ar due to 
pyroxene and apatite inclusions, and the $132 \mathrm{Ma}$ age of the amphibole-biotite aliquots. This last result very probably corresponds to the dyke emplacement event, confirming the genetic relationship between group A and the PMP. Whole rock dating in a sericitefree group $B$ dyke provided maximum age of $108 \mathrm{Ma}$, which would imply that $A$ and $B$ groups are not coeval. The similarity between the last age and the uplifting event of Southwestern Brazilian coast suggests that the dykes of group B could have been generated during such process, which also altered (sericitized) the plagioclases of the group A dykes.

KEY-WORDS: Serra do Mar Dyke Swarm, Paraná Magmatic Province, Tholeiitic magmatism of the Região dos Lagos; Mafic Dyke Swarms 


\section{AGRADECIMENTOS}

Entre os ipês da Universidade de São Paulo e as Bottle-Tree's de Brisbane, minha gratidão estende-se por mais de 14 mil quilômetros.

Inicialmente, agradeço à Fundação de Amparo à Pesquisa do Estado de São Paulo e à Comissão de Aperfeiçoamento de Pessoal de Nível Superior pelo financiamento de trabalho de campo e análises, de meu estágio no exterior e de minha bolsa, os quais tornaram possível a execução do projeto (processos 2012/06082-6, 2014/22948-9 e 2015/23624-5).

Agradeço à minha orientadora, Leila Soares Marques, pelo apoio e dedicação incansáveis e perenes, pela paciência quando me perdi em meio a tantos diagramas, pelo otimismo quando achei que nada daria certo, pelas críticas científicas necessárias quando estive otimista demais. E, acima de tudo, pela força e generosidade delicadamente alternadas, que sempre impressionam.

Agradeço ao meu supervisor em Brisbane, Paulo Vasconcelos, pela abertura em conversar com uma estudante perdida no SSAGI, pelo apoio à estudante perdida em Brisbane, pela incrível paciência com a estudante perdida no Argon Lab. E, em todos estes momentos, por não admitir que eu me permitisse permanecer perdida.

Também tenho muito a agradecer ao pessoal de todos os laboratórios pelos quais passei. No laboratório de Geofísica Nuclear, do IAG-USP, ao técnico Roberto Keiji, pela prontidão em esclarecer e re-esclarecer reações químicas. No Centro de Pesquisas Geocronológicas, do IGc-USP, a todo o corpo técnico, e em especial à Liliane Petronilho, que me acompanha desde a graduação e confia às minhas mãos tantas colunas delicadas. A todo pessoal envolvido no Argon Geochronology Laboratory (School of Earth Sciences - UQ), em especial ao David Thiede, pelo apoio e pela paciência com minhas muitas perguntas, inseguranças e alíquotas de anfibólios e biotitas, e às colegas de sala e laboratório Hevelyn Monteiro e Zhe Ren pela incansável ajuda, e pela prontidão em me acalmar e me fazer rir nas vezes em que achei que tinha diminuído a vida útil do espectrômetro.

Eu sou muito grata também aos colegas envolvidos na amostragem dos diques, que compartilharam das dúvidas, broncas de fiscais ambientais, belas vistas para o mar 
e praias de nudismo em Búzios, Cabo Frio e Arraial do Cabo: à professora Marcia Ernesto, que tanto contribuiu com o projeto como um todo, desde o seu início, ao professor Fábio Machado, por tantos esclarecimentos importantes e pelas técnicas especiais com a marreta, e ao Caio Vicentini, por ser sempre tão prestativo e doce, e por contribuir com as discussões, em qualquer situação.

Agradeço também a todo o corpo docente e técnico-administrativo do IAG-USP, em especial aos professores Naomi Ussami e Ricardo Trindade, sempre disponíveis, prestativos e abertos a discussões científicas, e ao professor Marcelo Bianchi, pela insistência em que eu fizesse meus próprios programas e coordenasse melhor meu banco de dados. Também agradeço à Isabela Carmo (Cenpes-Petrobrás) pela orientação e auxílio nos meus primeiros passos na petrografia. Na UQ, não posso deixar de citar Indira Jones, sempre tão rápida a resolver meus maiores e menores problemas de estudante e estrangeira.

Por fim, agradeço àqueles que não estiveram diretamente envolvidos no trabalho, mas ainda assim lhe foram fundamentais. Aos meus amigos de graduação e pósgraduação, dentre eles Wil, Grá, Plinio, Janine, Cabelo, Dani e Aline, tão importantes dentro e fora da sala E208. Do lado de fora, Adriano, Sônia, Karine Verde, Lais, Fernanda, Caio Carvas, Carla e Vitor, sempre tão inspiradores e presentes quando estive em conflito com a pós, e todo o resto. Ao Rafa, por me fazer sair da USP, e me ensinar a gostar de sorvete - e, por vezes, por questionar toda validade científica do meu projeto enquanto eu tomava sorvete. À minha mãe, de quem eu tenho tanto orgulho, por todo apoio, compreensão e dedicação, tão grandes que me parecem intangíveis. Ao meu pai, por me mostrar como é bom que o mundo tenha tantos mistérios. 


\section{SUMÁRIO}

1. INTRODUÇÃO

2. CONTEXTO TECTÔNICO E GEOLÓGICO ........................................................4

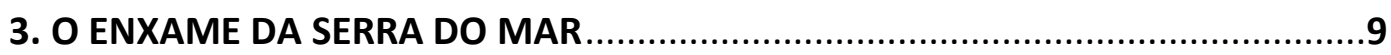

3.1. Aspectos geoquímicos dos diques BTi do ESM na Região dos Lagos (RJ) ...12

3.2. Geocronologia ${ }^{40} \mathrm{Ar} /{ }^{39} \mathrm{Ar}$ dos corpos intrusivos do ESM ............................13

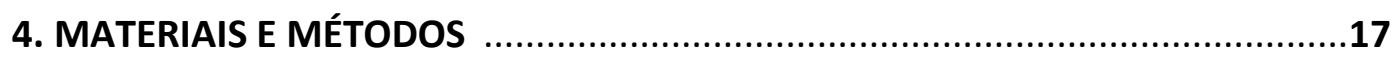

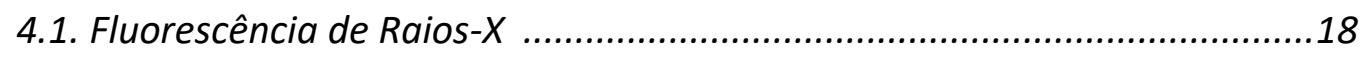

4.2. Espectrometria de massa por plasma acoplado indutivamente ................20

4.3. Isótopos de Sr, Nd e Pb e Espectrometria de Massa Termoiônica .............21

4.4. Microscopia Eletrônica de Varredura e Espectroscopia Dispersiva de

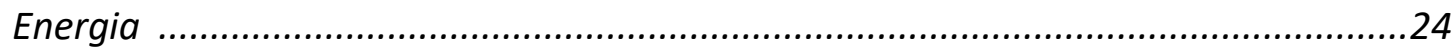

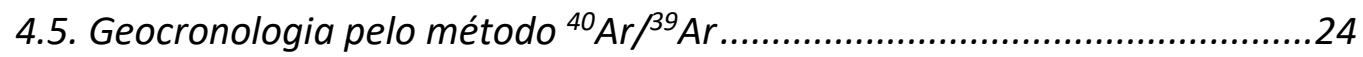

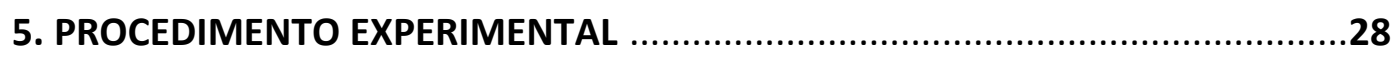

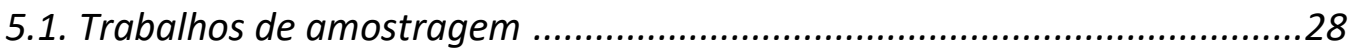

5.2. Preparação das amostras para análises geoquímicas e isotópicas ............28

5.2.1 Protocolo de preparação de amostras para análises de $\mathrm{Pb}$..................30

5.2.2 Preparação das amostras da Região dos Lagos ...................................30

5.3. Preparação de amostras para datação ${ }^{40} \mathrm{Ar} /{ }^{\beta 9} \mathrm{Ar}$......................................35

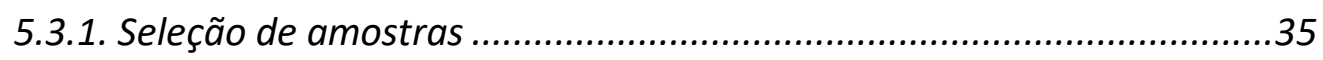

5.3.2. Separação de plagioclásio ................................................................36

5.3.3. Seleção de grãos, encapsulação para monitoramento de recuo,

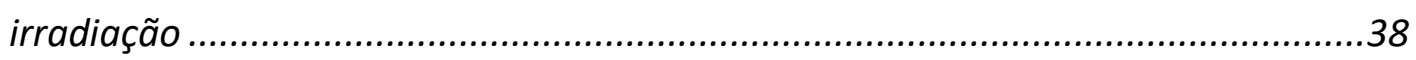

5.3.4. Análise por aquecimento em etapas e espectrometria de massa........39

5.3.5. Correções e processamento dos dados..............................................41

5.3.6. Análise petrográfica por microscópio óptico, MEV e EDE...................41

6. RESULTADOS E DISCUSSÕES ............................................................ 42

6.1. Caracterização geoquímica dos diques investigados ..............................42

6.1.1. Elementos maiores e menores .....................................................42

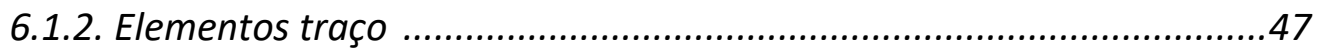


6.1.3. Comparações com diques BTi aflorantes na serra e basaltos da PMP 55

6.2. Análises de isótopos de $\mathrm{Sr}, \mathrm{Nd}$ e Pb e aspectos petrogenéticos .................57

6.3. Algumas considerações petrográficas e análise por MEV e EDE ...............65

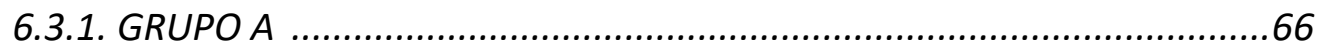

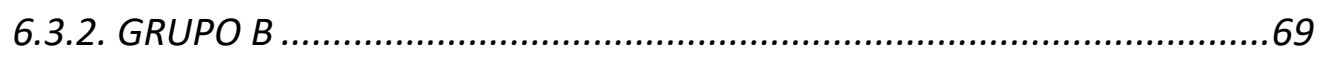

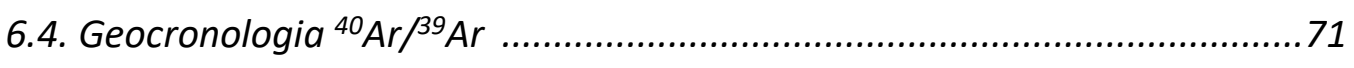

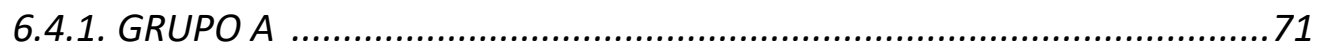

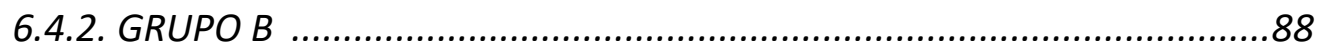

6.5. Resumo dos principais resultados geocronológicos e integração com as

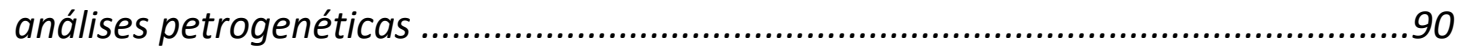

7. CONSIDERAÇÕES FINAIS ............................................................. 94

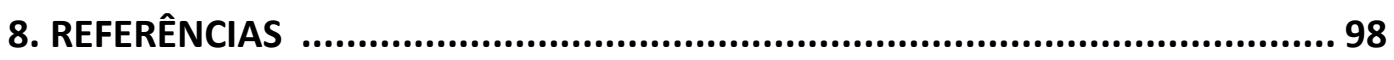

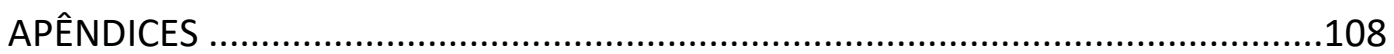

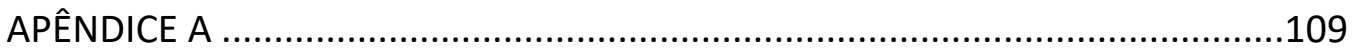

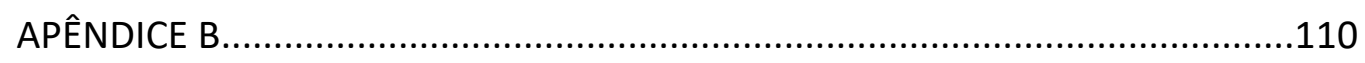

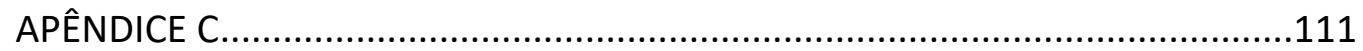




\section{V. ÍNDICE DE FIGURAS}

Figura 2.1: Sistema Orogênico Mantiqueira e seus principais orógenos, agrupados nos segmentos Setentrional, Central e Meridional. O Terreno Apiaí encontra-se na extremidade sul do Orógeno Brasília. Retirado de Heilbron et al., 2004.

Figura 2.2: Modelo de seção geológica do Orógeno Ribeira, modificado de Schmitt et al. (2016), com estimativa de localização da linha de ruptura continental no Terreno Cabo Frio.

Figura 3.1: A Província Magmática do Paraná e seus principais conjuntos de diques: (1) embasamento cristalino; (2) rochas sedimentares pré-vulcânicas (paleozoicos); (3) rochas vulcânicas básicas a intermediárias da Província Magmática do Paraná; (4) rochas ácidas do tipo Palmas da Província Magmática do Paraná; (5) rochas ácidas do tipo Chapecó da Província Magmática do Paraná; (6) enxames de diques da Província Magmática do Paraná; (7) rochas sedimentares pós-vulcânicas (principalmente do Cretáceo Superior); (8) alinhamentos tectônicos e/ou magnéticos. Em vermelho, o Enxame da Serra do Mar. Adaptado de Marques (2001).

Figura 5.1: Mapa geológico da Região dos Lagos (RJ) e localização dos diques amostrados. 1-(LM-DA-)200; 2-206; 3-203; 4-204; 5-205; 6-BZ-4R; 7-BZ-5R; 8-6R; 9-BZ-15N; 10-207; 11-208; 12-158; 13-161; 14-209; 15-210; 16-183; 17-182; 18211; 19-155; 20-212; 21-152; 22-150. I (Qha) - Depósito Colúvio-Aluvionar arenosíltico-argiloso (Quaternário); II (Qphr) - Depósito Marinho e Flúvio-Marinho síltico-areno-argiloso (Quaternário); III (Qphm) - Depósito de Restinga de areias quartzosas (Quaternário); IV (Tb) - Grupo Barreiras, depósito detrítico de cascalhos, argilo-arenoso (Terciário); $\mathrm{V}(\mathrm{KT} \lambda)$ - Rochas alcalinas (Cretácio/Terciário); VI (MNb) - Complexo Búzios, com cianita-sillimanitagranada-biotita xistos e gnaisses quartzo-feldspáticos (Meso/Neoproterozoico); VII (MNps) - Complexo Paraíba do Sul, com cianita-sillimanita-granada-biotita xistos (Meso/Neoproterozoico); VIII (P $\lambda 1 \mathrm{rl}$ ) - Complexo Região dos Lagos, com hornblenda-biotita ortognaisses calci-alcalinos (Paleoproterozoico). Fonte: "Mapa Geológico do Estado do Rio de Janeiro" (CPRM e DRM-R, 2000). .29

Figura 6.1: Diagrama TAS dos 22 diques coletados. As amostras do grupo $A$, mais primitivo, estão representadas em verde; as do grupo $B$, mais evoluído, em laranja. As amostras em azul foram descartadas devido a processos de alteração. A linha roxa separa os campos das rochas alcalinas e subalcalinas (Irvine \& Baragar, 1971), enquanto a preta tracejada separa os basaltos alcalinos dos toleíticos de acordo com Zanettin (1984).

Figura 6.2: Diagrama R1-R2 de nomenclatura química dos diques coletados. $O$ padrão de cores dos símbolos obedece aos critérios da figura 5.1. A amostra LMDA-183 está assinalada com um asterisco $\left({ }^{*}\right)$. 
Figura 6.3: Diagrama AFM de investigação de evolução magmática, com as curvas de diferenciação e de separação das séries toleíticas e alcalinas propostas por Kuno (1968) e Irvine \& Baragar (1971).

Figura 6.4: Diagramas de variação de elementos maiores (\%) em função da concentração de $\mathrm{MgO}$ (\%). Grupo A: verde; grupo B: laranja. 46

Figura 6.5: Diagramas de elementos traço compatíveis e incompatíveis em função dos teores de Th. Grupo A: verde; grupo B: Iaranja.

Figura 6.6: Padrões de abundância dos elementos terras raras do grupo A (a) e B (b), juntamente aos dados de Bennio et al. (2003; linhas tracejadas). No canto superior direito, padrão de abundância para as rochas dos dois grupos

Figura 6.7: Diagramas de razões de elementos terras raras normalizados pelo condrito $\mathrm{Cl}$ dos grupos A (verde) e B (laranja). Os círculos com um ponto central correspondem aos dados de Bennio et al. (2003).

Figura 6.8: Padrões de abundância dos elementos incompatíveis do grupo $A(A)$ e B (B), juntamente aos dados de Bennio et al. (2003; linha tracejada). No canto superior direito, padrão de abundância para as rochas dos dois grupos. .54

Figura 6.9: Diagramas de razões de elementos traço incompatíveis em função das concentrações de Th. Grupo A: verde; grupo B: laranja. Os dados de A e B representados com círculos com pontos centrais correspondem às amostras de Bennio et al. (2003), enquanto os círculos vazados azuis às de Corval (2009). ....56

Figura 6.10: Diagramas de elementos traço compatíveis e incompatíveis dos diques estudados, juntamente aos derrames e intrusões BTi da PMP. Dados do grupo A e B representados com um círculo com um ponto central foram retirados de Bennio et al. (2003)

Figura 6.11: Diagramas de razões isotópicas iniciais de $\mathrm{Sr}$ e $\mathrm{Nd}$ dos grupos $\mathrm{A} \mathrm{e} \mathrm{B}$, juntamente aos derrames BTi da PMP e diques primitivos da Namíbia. Os círculos com um ponto central representam os dados de Bennio et al. (2003). .60

Figura 6.12: Diagramas de razões isotópicas iniciais de $\mathrm{Sr}, \mathrm{Nd}$ e $\mathrm{Pb}$ dos grupos $\mathrm{A}$ e B, juntamente aos derrames BTi da PMP e diques primitivos da Namíbia. Os dados representados com um círculo vazado apresentam comportamento anômalo nas razões isotópicas de $\mathrm{Pb}$.

Figura 6.13: Diagramas de razões isotópicas iniciais de $\mathrm{Pb}$ em função de $1 / \mathrm{Pb}$ dos grupos A e B, juntamente aos derrames BTi da PMP e diques primitivos da Namíbia. Os dados representados com um círculo vazado apresentam comportamento anômalo nas razões isotópicas de $\mathrm{Pb}$.

Figura 6.14: Modelos AFC para média de diques Horingbaai (Namíbia), gnaisse da Praia das Conchas (caso do Sr e Nd; Fonseca, 1993) e granitos da suíte Paulo Lopes 
(caso do Pb; Florisbal, 2011). As concentrações de Pb estão em $\mu \mathrm{g} / \mathrm{g} ; \mathrm{D}_{\mathrm{Nd}}=0.09$; $D_{\mathrm{Sr}}=0.68 ; D_{\mathrm{Pb}}=0.52 ; \mathrm{r}=0.15$.

Figura 6.15: Diagramas de razões de elementos incompatíveis normalizados pelo manto primitivo em função de $\mathrm{MgO}(\%)$ e $\mathrm{La}(\mu \mathrm{g} / \mathrm{g})$ dos grupos A (verde) e B (laranja). .65

Figura 6.16: Concentrações de elementos traço $(\mu \mathrm{g} / \mathrm{g})$ em função das razões isotópicas iniciais ${ }^{87} \mathrm{Sr} /{ }^{86} \mathrm{Sr}$.

Figura 6.17: (a) Fotomicrografia com polarizador cruzado de plagioclásio (PI) altamente sericitizado em sua porção anortítica (An); as bordas albíticas (Ab) permanecem frescas. (b) Fotomicrografia com polarizador cruzado de anfibólio (Anf) em meio a cristais de plagioclásio e piroxênio ( $P x)$, além de argilominerais (Arg). (c) Inclusões de apatita (Ap) em fenocristal de plagioclásio, associadas a zonas de fratura (imagem de MEV). (d) Padrão irregular de zoneamento de fenocristal de plagioclásio (imagem de MEV)

Figura 6.18: (a) Inclusões de apatita e piroxênio em fenocristal de plagioclásio (imagem de MEV). (b) Inclusões de sulfeto (Sf) e piroxênio em cristal de plagioclásio da matriz, o qual também apresenta forte zoneamento composicional (imagem de MEV). (c) Fotomicrografia com polarizador cruzado mostrando zoneamento de fenocristal de plagioclásio, com região central sericitizada. .68

Figura 6.19: (a) Fotomicrografia com polarizador cruzado de fenocristal de plagioclásio livre de sericitização em meio à matriz de plagioclásios e clinopiroxênios. (b) Fotomicrografia com polarizador cruzado mostrando forte padrão de zoneamento de fenocristal de plagioclásio, com pequenas ocorrências de sericita. (c) Fotomicrografia sob luz polarizada mostrando a ocorrência de acentuada sericitização em fenocristais de plagioclásio.

Figura 6.20: (a) Fotomicrografia sob luz polarizada mostrando fenocristal de plagioclásio com reabsorção na parte central, e apresentando argilominerais nas bordas. (b) Fotomicrografia com polarizador cruzado mostrando fenocristal de plagioclásio zonado e livre de sericita. (c) Padrão de zoneamento de fenocristais de plagioclásio (imagem de MEV)......

Figura 6.21: Espectro de idade das alíquotas de plagioclásio sericitizado da amostra LM-DA-203.

Figura 6.22: Isócrona das alíquotas de plagioclásio sericitizado da amostra LM-DA203.

Figura 6.23: Diagrama de probabilidade de idade das alíquotas de plagioclásio sericitizado da amostra LM-DA-203.

Figura 6.24: Espectro de idade da alíquota de plagioclásio fresco da amostra LMDA-203. 
Figura 6.25: Isócrona das alíquotas de plagioclásio fresco da amostra LM-DA-203.

Figura 6.26: Diagrama de probabilidade de idade da alíquota de plagioclásio fresco da amostra LM-DA-203. .77

Figura 6.27: Espectro de idade da alíquota de anfibólio e biotita da amostra LMDA-203.

Figura 6.28: Isócrona das alíquotas de anfibólio e biotita da amostra LM-DA-203.

Figura 6.29: Diagrama de probabilidade de idade da alíquota de anfibólio e biotita da amostra LM-DA-203.

Figura 6.30: Espectro de idade da alíquota de plagioclásio sericitizado da amostra LM-DA-150.

Figura 6.31: Isócrona da alíquota de plagioclásio sericitizado da amostra LM-DA150.

Figura 6.32: Diagrama de probabilidade de idade da alíquota de plagioclásio sericitizado da amostra LM-DA-150.

Figura 6.33: Espectro de idade da alíquota de plagioclásio fresco da amostra LMDA-150.

Figura 6.34: Isócrona da alíquota de plagioclásio fresco da amostra LM-DA-150.

Figura 6.35: Diagrama de probabilidade de idade da alíquota de plagioclásio fresco da amostra LM-DA-150.

Figura 6.36: Espectro de idade de rocha total da amostra LM-BZ-5R. .86

Figura 6.37: Espectro de idade de plagioclásio fresco da amostra LM-BZ-5R......86

Figura 6.38: Espectro de idade de plagioclásio sericitizado da amostra LM-BZ-5R.

Figura 6.39: Espectro de idade de outra alíquota de plagioclásio sericitizado da amostra LM-BZ-5R

Figura 6.40: Espectro de idade de rocha total da amostra LM-DA-161. .89

Figura 6.41: Isócrona de rocha total da amostra LM-DA-161. .89 
Figura 6.42: Diagrama de probabilidade de idade de rocha total da amostra LMDA-161. .90

Figura C.1: Espectro de idades obtido para o padrão GA-1550, utilizado nas datações ${ }^{40} \mathrm{Ar} /{ }^{39} \mathrm{Ar}$.

Figura C.2: Isócrona obtida para o padrão GA-1550, utilizado nas datações ${ }^{40} \mathrm{Ar} /{ }^{39} \mathrm{Ar}$.

Figura C.3: Diagrama de probabilidade de idades obtido para o padrão GA-1550, utilizado nas datações ${ }^{40} \mathrm{Ar} /{ }^{39} \mathrm{Ar}$. 


\section{V. ÍNDICE DE TABELAS}

Tabela 5.1: Etapas do protocolo de preparação utilizado no CPGeo-USP.

.30

Tabela 6.1: Concentrações de elementos maiores e menores (\%) determinados por Fluorescência de Raios-X

Tabela 6.2: Concentrações $(\mu \mathrm{g} / \mathrm{g}$ ) de elementos traço obtidos por ICP-MS.

Tabela 6.3: Razões isotópicas de $\mathrm{Sr}, \mathrm{Nd}$ e $\mathrm{Pb}$ medidas e recalculadas, juntamente às concentrações de $\mathrm{Rb}(\mathrm{FRX}), \mathrm{Sr}(\mathrm{FRX}), \mathrm{Nd}, \mathrm{U}$, Th e $\mathrm{Pb}$ (ICP-MS; em $\mu \mathrm{g} / \mathrm{g}$ ). As incertezas associadas aos valores medidos são fornecidas entre parênteses, e correspondem às últimas casas decimais. .59

Tabela 6.4: Resumo dos resultados de geocronologia ${ }^{40} \mathrm{Ar} /{ }^{39} \mathrm{Ar}$ para cada uma das amostras analisadas.

Tabela A.1: Determinações de elementos traço $(\mu \mathrm{g} / \mathrm{g})$ via FRX. 109

Tabela B.1: Valores de concentração de elementos traço $(\mu \mathrm{g} / \mathrm{g})$ obtidos e certificados para o padrão BRP-1 nas análises de ICP-MS. 


\section{INTRODUÇÃO}

A porção meridional do Brasil foi alvo de um dos maiores eventos de vulcanismo intracontinental do mundo, com a extrusão de mais de $600.000 \mathrm{~km}^{3}$ de lavas sobre a Bacia do Paraná (e.g. Piccirillo \& Melfi, 1988; Peate, 1997). Esse vulcanismo de natureza toleítica, juntamente com as rochas intrusivas associadas, forma a Província Magmática do Paraná (PMP), que precedeu a abertura do Atlântico Sul e alastrou-se também pelos territórios da Argentina, Paraguai e Uruguai, além de apresentar uma correspondente menor no continente africano, dentro dos territórios da Namíbia e de Angola, a chamada Província Etendeka. Embora muitos estudos já tenham se dedicado a essas rochas extrusivas e intrusivas, existem ainda muitas questões acerca dos processos petrogenéticos e fontes mantélicas envolvidos, e também sobre a sequência de processos tectônicos causadores da ruptura continental (e.g. Milner \& Le Roex; 1996; Ewart et al., 1998, 2004; Comin- Chiaramonti et al., 1997; Gibson et al., 1999; Peate et al., 1999; Marques et al., 1999; Ernesto et al., 2002; Valente et al., 2007; Rocha Jr. et al., 2012, 2013; Ussami et al., 2012; Almeida et al., 2013).

A PMP está associada a uma quantidade significativa de atividade ígnea intrusiva, que abrange sills, situados principalmente na região nordeste da província, e enxames de diques. Dentre os últimos, destacam-se os de Ponta Grossa (Paraná), Florianópolis (Santa Catarina) e Serra do Mar (ESM; na região do Vale do Paraíba e na costa dos Estados de São Paulo e Rio de Janeiro; Almeida, 1986; Piccirillo \& Melfi, 1988; Piccirillo et al., 1990; Peate, 1997; Raposo et al., 1998; Marques \& Ernesto, 2004; Guedes et al., 2005, 2016; Valente et al., 2007; Corval, 2009). Muitos trabalhos têm se esforçado em estabelecer relações entre os diques e os diferentes estágios de abertura do Atlântico Sul, propondo geralmente que sua colocação está relacionada a processos de soerguimento térmico, acomodação tectônica, e à desestabilização prévia da litosfera (Chang et al., 1992; Ernst \& Buchan, 1997, Coutinho, 2008; Guedes, 2007; Guedes et al., 2016; Almeida et al., 2013). Os enxames costeiros estão geralmente associados a zonas paleozoicas de sutura, ligadas à amalgamação do Gondwana, e suas direções seguem aquelas do embasamento (Almeida, 1986; Thompson et al., 2001; Marques, 2001; Almeida et al., 2013; Florisbal, 2014). 
O ESM, em particular, destaca-se ao longo do litoral do Sudeste do Brasil, estendendo-se do Estado do Rio de Janeiro ao Estado de São Paulo, e adentrando o continente até o Vale do Paraíba. Trata-se de um grande enxame de diques toleíticos de direção preferencial NE, sendo intermediário em extensão e quantidade de corpos entre o Enxame de Ponta Grossa e o Enxame de Florianópolis. Suas centenas de diques subverticais, no geral, apresentam espessuras de centímetros a dezenas de metros, além de extensões amplamente variáveis, que chegam aos 15 km (Almeida, 1986).

Majoritariamente, tais diques apresentam teores de $\mathrm{TiO}_{2}$ acima de 3\%, e abrangem litotipos básicos e intermediários (Garda \& Scorscher, 1996; Valente et al., 1997; Marques, 2001; Corval et al., 2008; Corval, 2009; Vicentini, 2015). Datações K-Ar, ${ }^{40} \mathrm{Ar} /{ }^{39} \mathrm{Ar}$ e dados paleomagnéticos mostram predomínio de idades em torno de 130$133 \mathrm{Ma}$, com ocorrências mais raras de idades mais recentes, em torno de 125 Ma (Renne et al., 1993; Turner et al., 1994; Deckart et al., 1998; Corval, 2009), e também mais antigas, entre 193-144 Ma, na região de Volta Redonda e Resende (Guedes et al., 2005; Marques et al., 2005; Guedes et al., 2016).

Entretanto, embora de modo subordinado e concentrado, o ESM apresenta também diques básicos de baixos teores de titânio $\left(\mathrm{BTi} ; \mathrm{TiO}_{2}<2 \%\right)$, os quais são quimicamente representados por basaltos toleíticos e andesi basaltos toleíticos (Marques, 2001; Corval, 2009). Estas intrusões ocorrem na região serrana do Estado do Rio de Janeiro e no litoral, na Região dos Lagos (Bennio, 2003; Corval, 2009). Os dois grupos apresentam características geoquímicas e isotópicas muito distintas, sendo que os da região serrana possuem maiores influências de componentes crustais, de modo semelhante aos derrames do tipo Gramado da PMP (Marques, 2001; Marques \& Ernesto, 2004).

Os diques da região costeira entre Arraial do Cabo, Cabo Frio e Armação dos Búzios, da Região dos Lagos, por sua vez, carregam particularidades consideráveis. Suas concentrações de elementos traços incompatíveis são marcadamente inferiores àquelas encontradas no restante do enxame, assim como as razões isotópicas de $\mathrm{Sr}$ (Bennio et al., 2003; Corval, 2009). Bennio et al. (2003) assinalaram também a presença de duas suítes magmáticas distintas na região. Em termos geocronológicos, determinações ${ }^{40} \mathrm{Ar} /{ }^{39} \mathrm{Ar}$ marcaram idades em torno de 50-60 Ma nos trabalhos de Bennio et al. (2003) e Corval (2009), ainda que com espectros de idade muito afetados por excesso de Ar. 
Embora Corval (2009) tenha relacionado tal comportamento ao reaquecimento regional sofrido durante o magmatismo intrusivo alcalino, o estudo paleomagnético mais recente realizado por Ernesto et al. (2014) identificou três pulsos magnéticos distintos, compatíveis com polaridades de cerca de 50, 100 e 130 Ma.

Tantas questões em aberto e particularidades acerca da litogeoquímica e das idades disponíveis fazem com que o papel do magmatismo intrusivo BTi do eixo da Região dos Lagos seja pouco compreendido no contexto da abertura do Atlântico Sul. O presente estudo teve por objetivo investigar amostras representativas de diques toleíticos de Arraial do Cabo, Cabo Frio e Búzios, procurando definir se, de fato, existiram pulsos magmáticos mais recentes, quais foram os processos petrogenéticos envolvidos na formação dessas intrusões, e sua associação com as diferentes fases de ruptura do paleocontinente Gondwana.

Este trabalho oferece novos resultados de elementos maiores e menores, obtidos por meio de Fluorescência de Raios-X, e elementos traço, determinados via ICP-MS, para 22 diques. Também foram realizadas análises das razões isotópicas de $\mathrm{Sr}, \mathrm{Nd}$ e $\mathrm{Pb}$ para 9 amostras. Os novos resultados foram utilizados para obter informações mais detalhadas acerca da gênese dos diques da Região dos Lagos, com ênfase na investigação da possibilidade de ocorrência de diversos pulsos magmáticos nessa área.

Para atingir esse objetivo, a obtenção de dados geocronológicos bastante confiáveis foi de fundamental importância. Desta forma, a datação ${ }^{40} \mathrm{Ar} /{ }^{39} \mathrm{Ar}$ buscou investigar efeitos de recuo durante a irradiação via encapsulação de alíquotas, procurando também detalhar possíveis perturbações nos espectros de idade que poderiam estar associadas a processos de alteração envolvendo sericitização e albitização presentes no plagioclásio. A presença de inclusões em grãos deste mesmo mineral foi ainda cuidadosamente analisada por meio de microscopia eletrônica de varredura, auxiliando na interpretação dos espectros de idade. Além de plagioclásios, foram analisados também anfibólios presentes em uma das amostras, conferindo maior robustez aos resultados obtidos. 


\section{CONTEXTO TECTÔNICO E GEOLÓGICO}

As rochas encaixantes do ESM integram o orógeno Faixa Ribeira, o qual, por sua vez, compõe um dos blocos que constituem a Província Mantiqueira, um grande sistema orogênico paralelo à costa Atlântica das regiões Sudeste e Sul do Brasil. Seus limites encontram as Províncias Tocantins, São Francisco e Paraná a Oeste, e as Bacias do Espírito Santo, Campos, Santos e Pelotas a Leste (Almeida et al., 1981). O sistema como um todo se estende do Sul da Bahia ao Uruguai, e é composto pelos orógenos Araçuaí, Ribeira, Dom Feliciano e São Gabriel. A Zona de Interferência entre os orógenos Brasília e Ribeira (terreno Apiaí na figura 2.1; Heilbron et al., 2004), usualmente, também é incluída na Província Mantiqueira como um componente à parte.

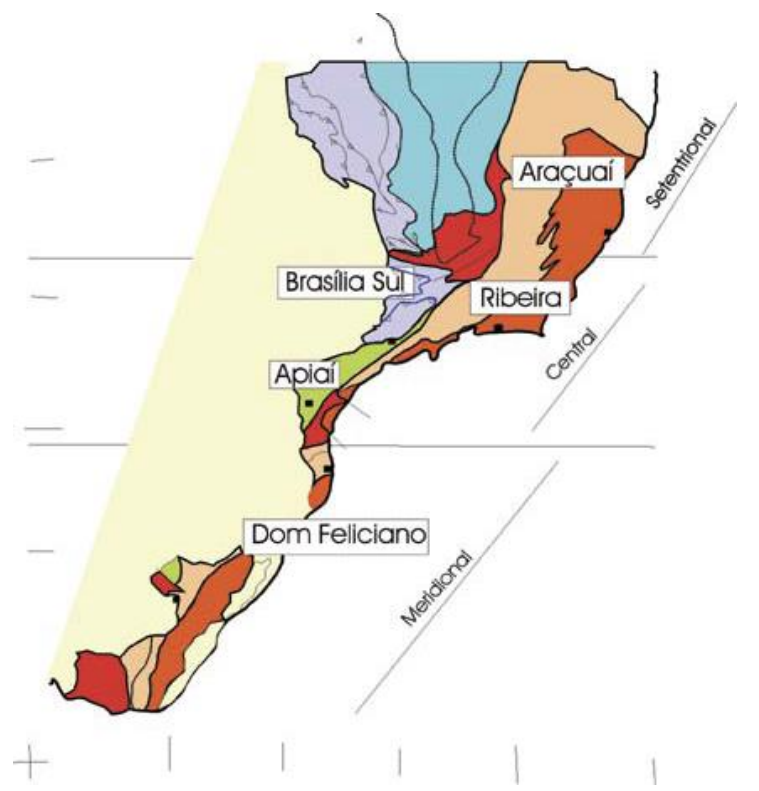

Figura 2.1: Sistema Orogênico Mantiqueira e seus principais orógenos, agrupados nos segmentos Setentrional, Central e Meridional. O Terreno Apiaí encontra-se na extremidade sul do Orógeno Brasília. Retirado de Heilbron et al., 2004.

O sistema orogênico da Província Mantiqueira remonta do NeoproterozoicoCambriano, e está intimamente ligado à amalgamação do paleocontinente Gondwana. Neste contexto, diversos crátons Arqueanos e Paleoproterozoicos e suas bacias marginais (São Francisco, Congo, Angola, Luis Alves, Rio de La Plata e Kalahari) aglutinaram-se, formando cadeias orogênicas (Araçuaí, Ribeira, Congo, Kaoko, Damara, Gariep e Dom Feliciano) e grandes zonas de cisalhamento (Heilbron et al., 2004; Almeida et al., 2013). A Orogênese Brasiliana, que compõe a amalgamação do Gondwana e que 
abrange uma série de colagens que estruturaram o embasamento da Plataforma SulAmericana atual (seguindo a definição de Brito-Neves et al., 1999), estendeu-se, no contexto da Província Mantiqueira, de 880 Ma até cerca de 480 Ma. Tal orogênese compreendeu tanto orógenos acrescionários quanto colisionais, dentre os quais se inclui o Orógeno Ribeira.

De modo geral, a Província Mantiqueira é dividida em três porções distintas, como forma de facilitar seu estudo: segmento setentrional, com o Orógeno Araçuaí; segmento central, com o Orógeno Ribeira, a Zona de Interferência, e terrenos Apiaí e Embu; e o segmento meridional, com os Orógenos Dom Feliciano e São Gabriel (Heilbron et al., 2004). O segmento central da Província Mantiqueira resultou da interação entre diversos blocos com a Placa São Francisco-Congo. Tanto na Orogenia Ribeira, quanto no sul do Cinturão Brasília, houve subducção de litosfera oceânica e geração de arcos magmáticos (Campos-Neto, 2000), ainda que o estágio colisional tenha causado a maior parte da deformação e metamorfismo. Este último, no Orógeno Ribeira, ocorreu entre 580 e 560 Ma, e teve grande influência nos processos colisionais do Orógeno Brasília há $630 \mathrm{Ma}$.

O Orógeno Ribeira apresenta, majoritariamente, tendências estruturais na direção NE-SW resultantes da colisão do Cráton do São Francisco com placas, microplacas e arcos de ilhas a Sudeste, em diversos estágios colisionais. Suas deformações se caracterizam por encurtamentos frontais (empurrões de mergulho íngreme) e zonas de transpressão destral (cisalhamento oblíquo), que resultam das múltiplas colisões oblíquas. O Orógeno divide-se em cinco terrenos principais, sendo eles Ocidental, Paraíba do Sul, Embu, Oriental e Cabo Frio; todos amalgamados em estágios colisionais (580 a 560 Ma), com exceção do último, que integrou o Orógeno numa colisão tardia, entre 520 e 510 Ma (Heilbron et al., 2004; Schmitt et al., 2004), e que constitui a encaixante dos diques investigados neste trabalho.

A colisão tardia, geralmente denominada Orogenia Búzios (Heilbron et al., 2004; Heilbron \& Machado, 2003), foi responsável não apenas pela deformação de baixo ângulo ao longo do Terreno Cabo Frio, com metamorfismo de pressão média a alta (Schmitt et al., 2004), mas também por processos de metamorfismo e deformação nos terrenos previamente amalgamados, os quais deram origem a novas zonas de cisalhamento (Heilbron et al., 2004). Após um processo de subducção, a orogênese 
desenvolveu-se por colisão e espessamento crustais, até que a borda do Terreno Oriental foi parcialmente sobreposta pelo Terreno Cabo Frio por meio de dobramentos inclinados, com falhas inversas associadas. Após o período colisional, uma zona de cisalhamento de direção NE-SW desenvolveu-se na região Oeste do Terreno Cabo Frio, finalizando a Orogenia Búzios em cerca de 495 Ma. O colapso orogênico posterior estendeu-se até $440 \mathrm{Ma}$, idade indicada por datações em pegmatitos associados (U-Pb em grãos de zircão; Schmitt et al., 2004; figura 2.2).

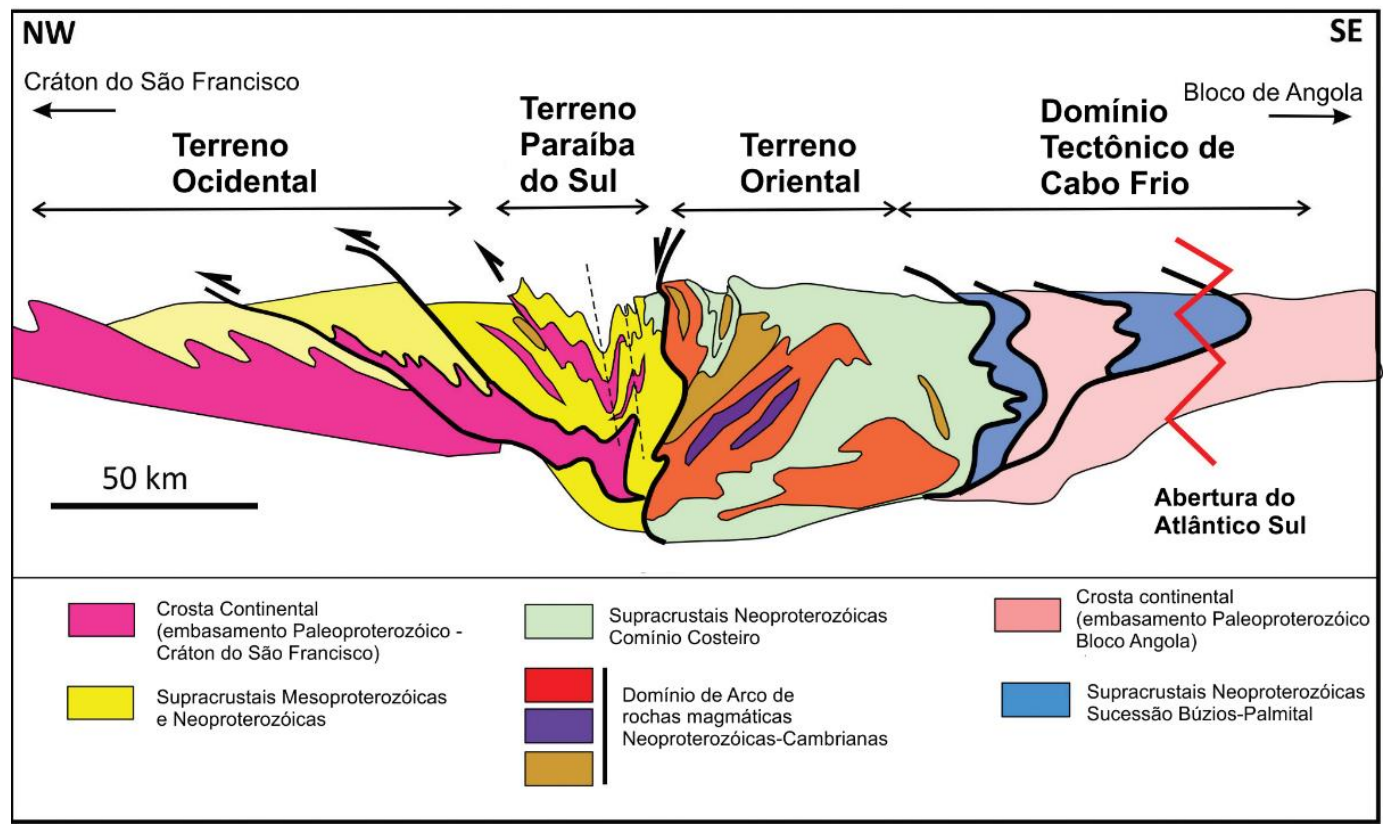

Figura 2.2: Modelo de seção geológica do Orógeno Ribeira, modificado de Schmitt et al. (2016), com estimativa de localização da linha de ruptura continental no Terreno Cabo Frio.

A complexidade das rochas que compõe o Terreno Cabo Frio reflete sua história tectônica. Os tipos litológicos encontrados abarcam, basicamente, rochas Neoproterozoico-Cambrianas, intercaladas em baixo ângulo por embasamento Paleoproterozoico retrabalhado, e que podem ser divididas entre as Unidades Região dos Lagos, Forte de São Mateus, Búzios e Palmital. Estudos mais recentes têm interpretado a porção aflorada do Terreno Cabo Frio como parte de sua região de sutura com o Terreno Oriental, cujo limite encontra-se no contato entre as unidades ortognáissicas e metassedimentares (Schmitt et al., 2016). A outra extremidade da Orogenia Búzios estaria localizada em Angola, onde encontra-se um cinturão cambriano similar (Monié et al., 2012; Schmitt et al., 2016). 
A Unidade Região dos Lagos apresenta composição félsica, compreendendo metagranitóides intercalados por dioritos, e gnaisses migmatíticos em regiões de maior deformação; datações U-Pb em zircões indicam idades de cerca de 1970 Ma para a cristalização dos protólitos, e de 520 Ma para seu retrabalhamento. A Unidade Forte de São Mateus, por sua vez, compreende gnaisses anfibolíticos bandados, que por vezes cortam a Unidade Região dos Lagos na forma de diques máficos boudinados (Schmitt et al., 2004). Tais unidades compõe o embasamento ortognáissico. As unidades Búzios e Palmital, por sua vez, constituem um pacote de rochas metassedimentares de provável deposição oceânica, associada ao início da Orogenia Búzios. Ambas apresentam composição anfibolítica, cálcio-silicática e quartzo-feldspática, e são interpretadas como variações laterais de uma mesma bacia. Nessa hipótese, as sucessões de predomínio de quartzo-feldspatos da Unidade Palmital representariam depósitos da porção central do leque, enquanto as sucessões da Unidade Búzios corresponderiam às suas porções pelágicas (Schmitt et al., 2004).

A abertura do Atlântico Sul iniciou-se com processos de rifteamento nas proximidades de onde hoje localiza-se a Província Magmática do Karoo (África) e na Patagônia (Argentina) (Jurássico Inferior, cerca de 190 a 178 Ma; Riley et al., 2005), após um longo período de aquiescência tectônica. À medida que antigas zonas de fraqueza foram reativadas, intrusões de diques desestabilizaram a litosfera por meio da reativação de zonas de falhamento ao longo do Jurássico (Almeida et al., 2013). No Mesozoico, as regiões orogênicas foram as mais afetadas durante o rifteamento do paleocontinente Gondwana em função de sua estrutura, demasiadamente complexa em comparação àquela dos crátons. A separação dos blocos São Francisco e Congo, seguindo este padrão, se deu na zona de colagem do Gondwana.

O processo de abertura também poderia ter ocorrido em meio a outras orogenias regionais, como, por exemplo, a zona de sutura com o Terreno Oriental. Sua ocorrência dentro do Terreno Cabo Frio sugere que a presença de magmatismo pode ter influenciado drasticamente o processo de rifteamento (Schmitt et al., 2016). Tal hipótese é corroborada por modelagens como a de Corti et al. (2003), a qual indica que intrusões magmáticas em zonas de deformação diminuem o esforço requerido em processos distensivos. Em modelagem termoreológica mais recente, Lavecchia et al. (2016) também aborda os efeitos significativos do magmatismo intrusivo na resistência 
crustal, e a geração de maiores ou menores zonas de fragilidade, de acordo com a litologia regional e com a velocidade de ascensão dos corpos magmáticos.

As intrusões do ESM presentes no Terreno Cabo Frio colocam-se, predominantemente seguindo a direção NE-SW (Bennio et al., 2003; Corval, 2009; Chang et al., 1992). A subida do magma originado por fusão parcial do manto durante o início da ruptura continental pode ter sido guiada por diferenças de espessura crustal, herdadas da amalgamação do Gondwana ou, ainda, do posterior processo de distensão. Schmitt et al. (2016) destaca a presença de uma zona de afinamento crustal através da faixa Ribeira, até o Terreno Cabo Frio, detectável no mapeamento de Assumpção et al. (2002); tal anomalia pode ter influenciado a mobilização magmática e facilitado a subida das intrusões.

Todas essas particularidades estruturais e reológicas do Terreno Cabo Frio podem ter influenciado o padrão de ruptura da margem continental sudeste brasileira já em seus estágios iniciais, muito previamente ao grande vulcanismo gerador da Província Paraná-Etendeka (132-134 Ma; Thiede \& Vasconcelos, 2010), o qual também pode ter ocorrido ao longo de descontinuidades crustais (Almeida, 1986; Ernesto et al., 2002). Outros levantamentos geofísicos também têm endossado esta hipótese, como a continuidade do alto sinal magnético e gravimétrico que se inicia na região de Cabo Frio e se estende até a Bacia de Santos, seguindo as tendências direcionais do ESM e das estruturas do embasamento. Estes dados geofísicos sugerem inclusive o prolongamento das intrusões magmáticas offshore (Stanton et al., 2010; Stanton \& Schmitt, 2015), o que as associaria diretamente à fase rifte. 


\section{O ENXAME DA SERRA DO MAR}

O Enxame da Serra do Mar (ESM) está presente em toda a zona costeira do Sudeste do Brasil, de Santos (SP) à Armação dos Búzios (RJ), onde se estende pelo interior até atingir o Vale do Paraíba e o Planalto Sul-Mineiro (figura 3.1). Seus corpos verticais a subverticais podem chegar a mais de $15 \mathrm{~km}$ de extensão, e apresentam uma ampla gama de espessuras (Almeida, 1986). A direção predominante NE-SW das intrusões é coincidente com aquela do embasamento cristalino (Marques, 2001; Almeida et al., 2013; Schmitt et al., 2016). A maior parte do enxame é constituída por litotipos básicos $\mathrm{ATi}\left(\mathrm{TiO}_{2}>3 \mathrm{wt} \%\right)$, quimicamente representados por basaltos andesíticos, lati-basaltos e lati-andesitos; no entanto, litotipos intermediários e ácidos (lati-andesitos, dacitos e riodacitos) ocorrem de maneira subordinada na região costeira do Estado de São Paulo (Comin-Chiaramonti et al., 1983; Piccirillo et al. 1988; Hawkesworth et al., 1992; Garda \& Schorcher, 1996; Marques, 2001; Corval, 2009; Vicentini, 2015). Diques contendo baixas concentrações de titânio (BTi; $\left.\mathrm{TiO}_{2}<3 w t \%\right)$ têm ocorrência em áreas restritas do enxame, e também apresentam grande variabilidade composicional (Marques, 2001; Bennio et al., 2003; Valente et al., 2007; Corval, 2009).

Estudos petrográficos dos diques do ESM atestam a ocorrência de texturas holocristalinas e hipocristalinas, de matriz equigranular ou inequigranular seriada, que apresentam variações de acordo com a região de amostragem dentro do dique (Garda \& Schorscher, 1996; Dutra, 2006; Corval, 2009). Texturas seriadas, porfiríticas, ofíticas e intersticiais são as mais comuns (Corval, 2009). A composição mineralógica essencial dos diques consiste em plagioclásio e clinopiroxênio (augita e, em menor quantidade, pigeonita); ambos se apresentam com granulometria fina a média. Além disso, em grãos de plagioclásio, é comum a ocorrência de sericitização, principalmente em zonas centrais. Subordinadamente, minerais opacos como a titano-magnetita e ilmenita (no geral, na forma de espinha-de-peixe) ocorrem com granulometria mais fina em regiões de contato dos minerais essenciais, ou ainda como inclusões. Quartzo, biotita, uralita, hornblenda e apatita apresentam-se como minerais acessórios; os grãos de biotita e uralita são produtos de alteração de piroxênios, e, muitas vezes, localizam-se nas regiões de borda, e podem ser acompanhados por grãos de hornblenda. Os grãos de apatita, por sua vez, ocorrem como inclusões em plagioclásios ou piroxênios. Nas porções 
oriental e central do ESM, há ocorrência de fenocristais de olivina (Dutra, 2006; Corval, 2009). Estimativas para a assembleia de fenocristais dos diques giram em torno de $10 \%$ de olivina, $40 \%$ de augita, e $50 \%$ de plagioclásio (Corval, 2009).

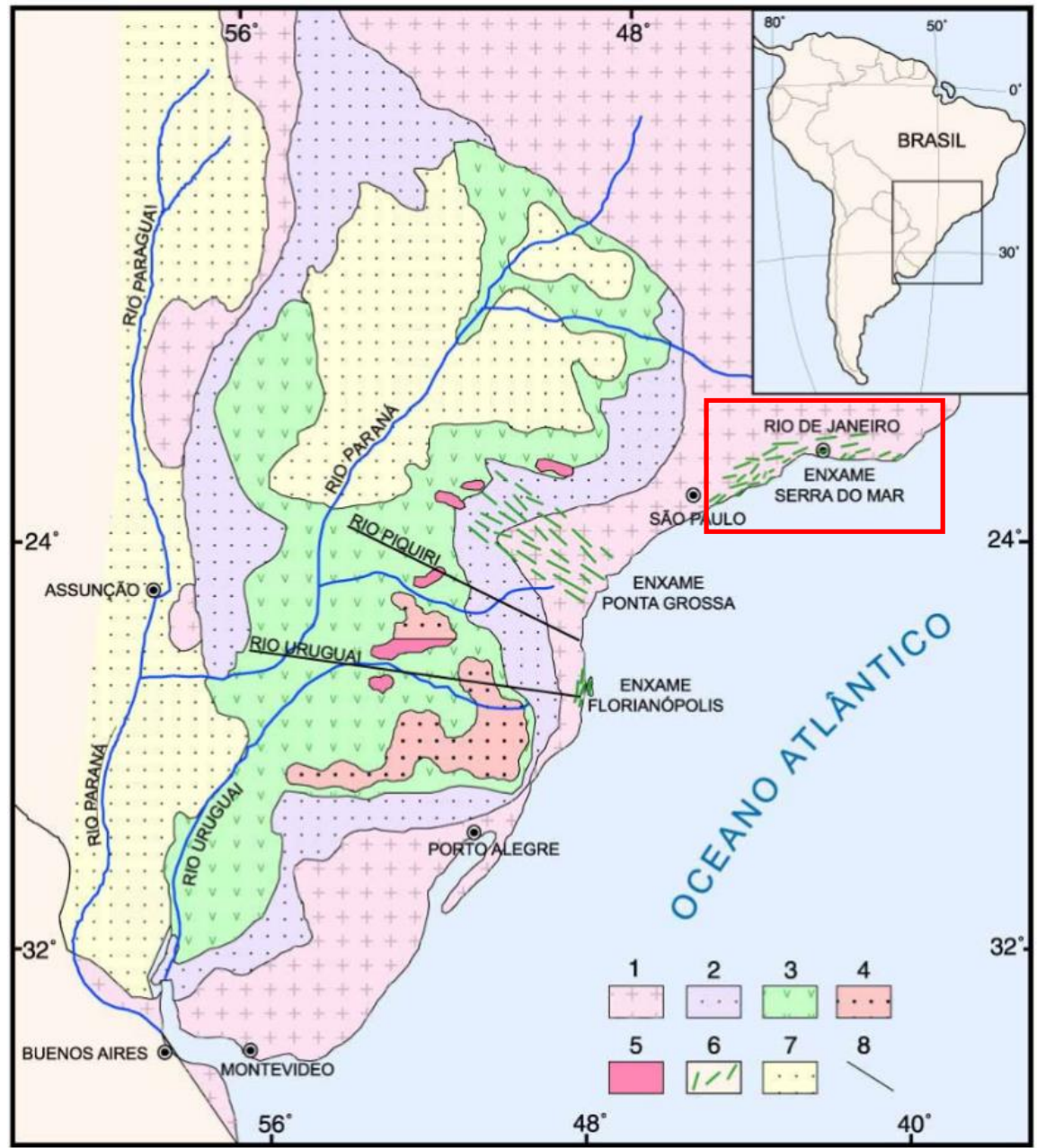

Figura 3.1: A Província Magmática do Paraná e seus principais conjuntos de diques. (1) embasamento cristalino; (2) rochas sedimentares pré-vulcânicas (paleozoicos); (3) rochas vulcânicas básicas a intermediárias da Província Magmática do Paraná; (4) rochas ácidas do tipo Palmas da Província Magmática do Paraná; (5) rochas ácidas do tipo Chapecó da Província Magmática do Paraná; (6) enxames de diques da Província Magmática do Paraná; (7) rochas sedimentares pós-vulcânicas (principalmente do Cretáceo Superior); (8) alinhamentos tectônicos e/ou magnéticos. Em vermelho, o Enxame da Serra do Mar. Adaptado de Marques (2001).

O ESM apresenta, assim como a PMP, rochas do tipo ATi e BTi. Cerca de $85 \%$ dos afloramentos apresentam $\mathrm{TiO}_{2}>3 \mathrm{wt} \%$, e maiores teores de elementos incompatíveis; os diques $\mathrm{BTi}$, por sua vez, são mais raros, sendo que sua maioria apresenta $\mathrm{TiO}_{2}<2 \mathrm{wt} \%$ (cerca de 10\% de todo o enxame; Comin-Chiaramonti et al., 1983; Marques, 2001; 
Marques \& Ernesto, 2004; Corval, 2009). As intrusões BTi localizam-se em regiões específicas da parte oriental do enxame, notadamente na Região dos Lagos e na região Serrana do Estado do Rio de Janeiro, denominadas, respectivamente, de Suíte Costa Azul e Suíte Serrana (Dutra , 2006).

Os diques de composição básica ATi apresentam teores de MgO entre 6-2\%, e podem ser discriminados em dois grupos distintos (conforme descrito em Marques, 2001): ATi-P ( $\mathrm{Sr}<550 \mu \mathrm{g} / \mathrm{g}$; semelhante aos basaltos do tipo Pitanga da PMP), ATi-M ( $\mathrm{S} r>550 \mu \mathrm{g} / \mathrm{g}$ e Ti/Y<500; representado por lati-andesitos), e ATi-U (Sr>550 $\mu \mathrm{g} / \mathrm{g}$ e $\mathrm{Ti} / Y>500$; semelhante ao tipo Urubici, e representado por basaltos andesíticos toleíticos), em ordem decrescente de abundância. O grupo ATi-M diferencia-se de derrames ATi conhecidos da PMP por ter sofrido intensos processos de contaminação crustal, indicados em suas razões de $\operatorname{Sr}\left(0,7062 \leq{ }^{87} \mathrm{Sr} /{ }^{86} \mathrm{Sr} \leq 0,7070\right)$, e por apresentar tendências levemente alcalinas, que podem resultar de fusão parcial de menor grau de fonte similar àquela que originou o grupo ATi-U (Marques, 2001). Além disso, o grupo também apresenta maiores concentrações de $\mathrm{SiO}_{2}, \mathrm{~K}_{2} \mathrm{O}, \mathrm{P}_{2} \mathrm{O}_{5}$ e elementos incompatíveis. As razões isotópicas dos diques ATi como um todo apontam a participação de fontes heterogêneas do manto sub-litosférico, e assimilação de material crustal: $0,70531 \leq{ }^{87} \mathrm{Sr} /{ }^{86} \mathrm{Sr}_{\mathrm{i}} \leq 0,70710 ; 0,51220 \leq{ }^{143} \mathrm{Nd} /{ }^{144} \mathrm{Nd}_{i} \leq 0,51260 ; 16,6 \leq$ ${ }^{206} \mathrm{~Pb} /{ }^{204} \mathrm{~Pb}_{\mathrm{i}} \leq 18,37 ; 15,51 \leq{ }^{207} \mathrm{~Pb} /{ }^{204} \mathrm{~Pb}_{\mathrm{i}} \leq 15,60 ; 35,90 \leq{ }^{208} \mathrm{~Pb} /{ }^{204} \mathrm{~Pb}_{\mathrm{i}} \leq 38,77$ (Garda, 1995; Marques, 2001; Corval, 2009; Carvas, 2014; Vicentini, 2015).

As intrusões BTi do ESM ocorrem em duas regiões distintas, com características geoquímicas e isotópicas particulares. O primeiro grupo, localizado na região serrana do Rio de Janeiro, apresenta comportamentos de elementos maiores, menores e traços e razões isotópicas de $\mathrm{Sr}\left({ }^{87} \mathrm{Sr} /{ }^{86} \mathrm{Sr} \geq 0,7060\right)$ similares àqueles dos basaltos $\mathrm{BTi}$ do sul da PMP (notadamente, do tipo Gramado; Peate et al., 1992; Marques, 2001). Heterogeneidades nas fontes envolvidas podem ser identificadas, assim como fortes indícios de assimilação crustal (enriquecimento em $\mathrm{Rb}, \mathrm{Ba}, \mathrm{K}, \mathrm{Ta}$ e ETR leves), de modo análogo aos diques BTi existentes nos Enxames de Ponta Grossa e Florianópolis (Marques, 2001; Marques \& Ernesto, 2004). Algumas semelhanças foram encontradas por Marques (2001) e Marques \& Ernesto (2004) ao comparar tais rochas com derrames e intrusões básicas toleíticas BTi da Bacia de Kwanza, no oeste de Angola, que estaria adjacente ao ESM antes da ruptura continental. Os diques angolanos, no entanto, não 
apresentam influências crustais significativas (Marzoli et al., 1999). Nos mesmos trabalhos, semelhanças entre os diques BTi serranos e os basaltos da Bacia de Campos, na plataforma continental do sudeste brasileiro, também foram identificadas.

Posteriormente, Corval (2009) descartou a possibilidade de que as suítes ATi e BTi serrana do ESM fossem cogenéticas baseando-se em modelagens de fusão mantélica, e sugeriu a existência de heterogeneidades em escala local. Componentes enriquecidas do tipo EMI, e empobrecidas como MORB e DMM foram sugeridas como participantes na petrogênese dessas rochas, em variados graus, com base em padrões de elementos traço e dados isotópicos de $\mathrm{Sr}, \mathrm{Nd}$ e $\mathrm{Pb}$.

O segundo grupo de intrusões BTI presente no ESM localiza-se na Região dos Lagos, nos arredores das cidades de Arraial do Cabo, Cabo Frio e Armação dos Búzios, e consiste no conjunto de maior interesse neste trabalho. Suas características serão mais detalhadamente descritas a seguir.

\subsection{Aspectos geoquímicos dos diques BTi do ESM na Região dos Lagos (RJ)}

Os diques BTi localizados na Região dos Lagos (RJ) mostram-se mais empobrecidos em álcalis, e apresentam, de acordo com Corval (2009), padrões de elementos traço semelhantes àqueles encontrados nos derrames do tipo Esmeralda da PMP. Neste trabalho, o comportamento das razões La/Yb e La/Nb sugeriu evolução por cristalização fracionada com assimilação de material crustal (AFC; Assimilation and Fractional Crystallization), sem mudanças de assembleia fracionante. Elementos traço incompatíveis mostraram que, ao contrário dos diques BTi da região serrana, tais intrusões apresentam características geoquímicas diferentes daquelas dos basaltos da Bacia de Campos (Corval et al., 2008; Corval, 2009).

Baseando-se em dados isotópicos de Sr e Nd, Dutra (2006) sugeriu que uma componente mantélica empobrecida poderia estar envolvida na petrogênese dos diques da Região dos Lagos. Essa tendência difere do padrão encontrado em diques BTi de outras porções do ESM, mais radiogênicos em Sr e com maiores contribuições de componentes crustais. Comparando as razões $\mathrm{La} / \mathrm{Yb}$ e La/Nb de intrusões BTi de todo o ESM, Dutra (2006) e Corval (2009) definiram duas suítes magmáticas BTi distintas, com limites nos valores $\mathrm{La} / \mathrm{Yb}=5,5$ e $\mathrm{La} / \mathrm{Nb}=1,5$. 
Em estudo prévio, focado nos diques toleíticos BTi de Cabo Frio, na Região dos Lagos, Bennio et al. (2003) também realizaram análises em diques BTi e discriminaram dois grupos magmáticos com base em concentrações de $\mathrm{Zr}, \mathrm{Al}_{2} \mathrm{O}_{3}, \mathrm{Fe}_{2} \mathrm{O}_{3} \mathrm{t}, \mathrm{MnO}$, $\mathrm{V}$ e $\mathrm{Y}$ : $\mathrm{O}$ primeiro deles, mais primitivo e denominado $\mathrm{A}\left(66 \leq[\mathrm{Zr}] \leq 114 \mu \mathrm{g} / \mathrm{g} ; \mathrm{Al}_{2} \mathrm{O}_{3}<15 \mathrm{wt} \%\right.$; $\mathrm{SiO}_{2}<52 \mathrm{wt} \% ; 145 \leq[\mathrm{Sr}] \leq 229 \mu \mathrm{g} / \mathrm{g} ; \mathrm{MgO}>5,5 \mathrm{wt} \%$ e $[\mathrm{V}]<540 \mu \mathrm{g} / \mathrm{g}$ ), e o segundo mais evoluído, denominado $\mathrm{B} \quad\left(93 \leq[\mathrm{Zr}] \leq 154 \mu \mathrm{g} / \mathrm{g} ; 14 \leq \mathrm{Al}_{2} \mathrm{O}_{3} \leq 16\right.$ wt\%; $\mathrm{SiO}_{2}>52$ wt\%; $227 \leq[\mathrm{Sr}] \leq 264 \mu \mathrm{g} / \mathrm{g} ; \mathrm{MgO}<6 \mathrm{wt} \%$ e $[\mathrm{V}]<350 \mu \mathrm{g} / \mathrm{g}$ ). Os dois grupos também foram distinguíveis por meio de razões e padrões de elementos traço incompatíveis, e apresentam razões isotópicas iniciais de $\mathrm{Sr}$ e $\mathrm{Nd}$ nitidamente distintas $\left(0,70426 \leq^{87} \mathrm{Sr} /{ }^{86} \mathrm{Sr}_{i} \leq 0,70434\right.$ e $+3,8 \leq \varepsilon \mathrm{Nd}_{i} \leq+2,3$ para A, e $0,70548 \leq{ }^{87} \mathrm{Sr} /{ }^{86} \mathrm{Sr}_{i} \leq 0,70613$ e $1,8 \leq \varepsilon \mathrm{Nd}_{i} \leq-2,2$ para $\left.\mathrm{B}\right)$; no entanto, nenhuma separação geográfica clara foi identificada. Cálculos de balanço de massa não permitiram estabelecer uma relação genética entre as rochas dos dois grupos magmáticos. Modelagens AFC e de mistura simples, assumindo contaminação crustal dos diques do grupo $B$, mostraram-se pouco prováveis por conta dos valores de coeficiente de partição e de porcentagem de assimilação aplicados.

Utilizando diagramas Ti/Y-Ti/Zr, Bennio et al. (2003) identificaram semelhanças entre os diques estudados e os basaltos Esmeralda da PMP. O grupo A aproximou-se de campos ocupados por amostras do tipo MORB, assim como os diques Horingbaai da Namíbia (parte da Província Etendeka), enquanto o grupo B aproximou-se parcialmente do campo dos basaltos BTi do tipo Ribeira. Diagramas de elementos incompatíveis mostraram que os diques da Região dos Lagos não se relacionam com as intrusões ATi do restante do ESM, assim como os basaltos da Bacia de Campos e os diques de seus vizinhos imediatos, em Angola (que se apresentam mais diferenciados). Os autores também ressaltaram que as assinaturas isotópicas não exibiram similaridades significativas com aquelas características da pluma de Tristão da Cunha.

\subsection{Geocronologia ${ }^{40} \mathrm{Ar} /{ }^{\beta 9} \mathrm{Ar}$ dos corpos intrusivos do ESM}

Embora muitas das datações ${ }^{40} \mathrm{Ar} /{ }^{39} \mathrm{Ar}$ tenham indicado idades entre 133-130 Ma para o magmatismo intrusivo do ESM (Turner et al., 1994; Deckart et al., 1998; Corval, 2009), alguns estudos geocronológicos e paleomagnéticos mais recentes sugerem que o magmatismo toleítico pode ter se estendido do período Jurássico (Guedes et al., 2005; 
Guedes et al., 2016) ao Paleogeno (Bennio et al., 2003; Ernesto et al., 2014). Isto implicaria assumir que o magmatismo intrusivo ocorreu em pulsos de idades que abrangem um período de tempo muito maior do que o vulcanismo da PMP (132-134 Ma; Renne et al. 1996; Ernesto et al., 1999; Thiede \& Vasconcelos, 2010; Florisbal et al., 2014).

A datação das rochas toleíticas intrusivas do ESM pelo método ${ }^{40} \mathrm{Ar} /{ }^{39} \mathrm{Ar}$, no geral, impõe muitos desafios. Os seus minerais portadores de $\mathrm{K}$, como o plagioclásio, apresentam baixos teores do elemento, o que resulta em baixos conteúdos de ${ }^{40} \mathrm{Ar}$ radiogênico após a irradiação, e diminui razões sinal/ruído durante a espectrometria de massa. Esse problema é intensificado pelas altas concentrações de Ca dos plagioclásios, que implicam maiores quantidades de ${ }^{37} \mathrm{Ar}$ radioativo nas análises, e consequente aumento do ruído de fundo no espectrômetro de massa. Além disso, a maioria dos diques é afetada por sericitização em grãos de plagioclásio e alterações em minerais máficos, o que pode dificultar a interpretação dos espectros de idades aparentes, os quais, não raramente, também são influenciados por excesso de Ar.

Todas as tentativas anteriores de datação dos diques toleíticos do ESM foram afetadas pelas dificuldades descritas. Turner et al. (1994) reportou idades entre $133,3 \pm 1,7$ e 129,4 $\pm 0,6$ Ma na região meridional do enxame, no Estado de São Paulo; tais valores foram obtidos por meio de análise step-heating via laser em grãos de plagioclásio e rocha-total. Os primeiros, no geral, resultaram em valores menores que os últimos, tendência que, segundo os autores, pode estar relacionada às fraturas e alterações associadas presentes nos plagioclásios. Posteriormente, Deckart et al. (1998) realizou análises em quatro grãos de plagioclásio provenientes de diques toleíticos $\mathrm{ATi}$, próximos à cidade do Rio de Janeiro. Os espectros de idade obtidos foram extremamente perturbados por excesso de Ar e pela presença de inclusões ricas em K, e pequenos platôs (máximo de $34 \%$ de $\%{ }^{39} \mathrm{Ar}$ liberado) foram definidos, simultaneamente, em baixas e altas temperaturas, atingindo valores entre $134,5 \pm 0,4 \mathrm{e}$ 129,8 $\pm 0,2$ Ma. Baseando-se nesses resultados e em análises geoquímicas, ambos os trabalhos atestaram relação direta entre o ESM e o vulcanismo na porção norte da PMP.

As datações ${ }^{40} \mathrm{Ar} /{ }^{39} \mathrm{Ar}$ do Jurássico foram detectadas pela primeira vez em Guedes (2007), por meio de análises em grãos de plagioclásio e rocha-total de diques da região central do ESM. Os espectros resultantes apresentaram grande influência de excesso de 
Ar, e as idades máximas se estenderam de $157 \pm 0,16 \mathrm{Ma}$ a $125,1 \pm 2,3 \mathrm{Ma}$. Os valores mais elevados foram obtidos em amostras das cidades de Volta Redonda e Resende. Recentemente, sete diques da mesma região e de Ilha Grande foram selecionados novamente por Guedes et al. (2016) com base em dados de campo, petrografia e geoquímica. As análises foram efetuadas em grãos de rocha-total, e definiram platôs com idades entre $155,4 \pm 3,4\left(65,5 \%\right.$ de $\left.\%{ }^{39} \mathrm{Ar}\right)$ e $149,8 \pm 3,3 \mathrm{Ma}\left(46,2 \%\right.$ de $\left.\%{ }^{39} \mathrm{Ar}\right)$, cujo comportamento, na maioria das vezes, indica excesso de $\operatorname{Ar}$ em baixas e altas temperaturas. Tal padrão foi atribuído às diferentes fases minerais portadoras de $\mathrm{Ar}$ existentes e a processos de intemperismo. Baseando-se em valores integrados das idades aparentes e excluindo resultados pouco confiáveis, os autores defendem que as intrusões da região de Resende-Ilha Grande datam do intervalo entre 156,5 $\pm 7,4$ e $144 \pm 3,2 \mathrm{Ma}$.

As idades mais recentes do ESM obtidas pelo método ${ }^{40} \mathrm{Ar} /{ }^{39} \mathrm{Ar}$ concentram-se na Região dos Lagos. Bennio et al. (2003) separou grãos de plagioclásio de três diques distintos das proximidades de Arraial do Cabo (RJ); todos eles possuíam impurezas e pequenas inclusões de piroxênios, sericita e clorita. Os espectros de idades obtidos foram marcados por excesso de Ar, que foi interpretado como resultante de incorporação da rocha encaixante. A presença das inclusões ricas em $\mathrm{K}$ nos grãos analisados não foi considerada significativa pelos autores para que exercesse influência nas idades. Idades máximas foram estabelecidas com base nos valores obtidos em temperaturas intermediárias: $77 \pm 7 \mathrm{Ma}\left(57 \%\right.$ do total de $\left.{ }^{39} \mathrm{Ar}\right), 54,8 \pm 0,3 \mathrm{Ma}(18,3 \%$ do ${ }^{39} \mathrm{Ar}$ ), e $55,2 \mathrm{Ma}$ (valor médio de quatro idades aparentes que compreendem $31 \%$ do $\left.{ }^{39} \mathrm{Ar}\right)$.

Em estudo mais recente, Corval (2009) selecionou grãos de plagioclásio pouco alterados de diques de diferentes regiões do ESM; em casos onde tal seleção não foi possível, foram separados grãos de rocha-total. As análises em plagioclásio foram muito perturbadas por excesso de Ar, e apenas a fração de rocha-total obedeceu ao critério de MSWD ("Mean Square of Wheight Deviates") proposto por Turner et al. (1994). Um deles, proveniente de Cabo Frio (RJ), apresentou a idade de $60,7 \pm 4,6 \mathrm{Ma}$, similar aos resultados encontrados por Bennio et al. (2003); esta idade, no entanto, foi considerada pouco confiável por ter sido possivelmente influenciada pelo reaquecimento regional 
promovido pelo magmatismo alcalino mais recente. Outra fração de rocha total, de um dique de Niterói (RJ), apresentou isócronas de 128,9₫1,3 Ma.

Recentemente, os resultados mais jovens de amostras da Região dos Lagos foram reiterados por Ernesto et al. (2014), por meio de dados paleomagnéticos. Os pólos detectados foram semelhantes aos de rochas vulcânicas da América do Sul de cerca de $50 \mathrm{Ma}$ (polaridade normal), $100 \mathrm{Ma}$ (reversa), e $130 \mathrm{Ma}$ (normal), o que sugere que o magmatismo toleítico intrusivo da região pode ter ocorrido em diferentes pulsos. Uma das motivações do presente trabalho foi estabelecer se, de fato, tais pulsos magmáticos podem ser confirmados pela geocronologia ${ }^{40} \mathrm{Ar} /{ }^{39} \mathrm{Ar}$, e se eles correspondem às duas suítes magmáticas discriminadas por Bennio et al. (2003) na mesma região. 


\section{MATERIAIS E MÉTODOS}

Para o estudo da petrogênese e da geocronologia dos diques investigados, diferentes metodologias foram selecionadas. Apresentamos, a seguir, os princípios básicos de cada um dos aspectos da geoquímica elemental e isotópica aplicados, seguidos de uma breve descrição de cada um dos métodos de análise utilizados, e de uma descrição teórica resumida acerca do método de datação ${ }^{40} \mathrm{Ar} /{ }^{39} \mathrm{Ar}$.

Os elementos maiores consistem nos dez principais óxidos constituintes dos minerais formadores das rochas, e definem a classificação geoquímica das amostras estudadas e sua nomenclatura. Além disso, importantes processos geoquímicos, como o fracionamento de minerais, podem ser inferidos das relações encontradas entre os diferentes óxidos em diagramas de duas ou mais variáveis. Para as amostras analisadas neste trabalho, a concentração dos elementos maiores e menores foi determinada por espectrometria por fluorescência de raios-X (FRX).

As concentrações de elementos traço em uma rocha, por sua vez, são inferiores a 0,1 wt\%; no entanto, o seu comportamento pode discriminar processos petrogenéticos de forma muito mais eficiente do que elementos maiores (Rollinson, 1993). Durante eventos de fusão parcial ou cristalização fracionada, cada elemento apresenta tendência particular de se concentrar na fase líquida ou sólida, de acordo com as condições de composição, temperatura, pressão, oxidação e estrutura cristalina do sistema. Tal tendência é expressa pelo coeficiente de partição:

$$
K d=C_{\text {elemento }_{i}}^{\text {mineral }} / C_{\text {elemento }_{i}}^{\text {líuido }}
$$

Onde $C_{\text {elemento }}$ é a concentração do elemento $i$ na fase mineral/líquida.

A partir dos valores de $K d$ de cada um dos minerais presentes na fase sólida fracionada durante um processo de cristalização do magma, ou ainda no sólido que está sofrendo fusão parcial, o coeficiente de partição global do elemento $i$ é dado por:

$$
D_{i}=x_{1} K d_{1}+x_{2} K d_{2}+\cdots+x_{n} K d_{n}
$$

Onde os valores $x_{m}$ indicam as proporções do mineral $m$ no sólido, e os fatores $K d_{m}$ são os coeficientes de partição do elemento $i$ para cada um dos minerais considerados (Wilson, 1989; Rollinson, 1993). 
Outra característica importante dos elementos traço é sua mobilidade, a qual define seu comportamento durante processos de hidrotermalismo ou metamorfismo. No geral, alta mobilidade está ligada a grandes raios iônicos e/ou pequena carga, o que dificulta a colocação de íons em estruturas cristalinas (Rollinson, 1993). Tanto o coeficiente de partição quanto a mobilidade dos elementos traço imprimem padrões comportamentais durante processos petrogenéticos, auxiliando o reconhecimento de fusão parcial ou cristalização fracionada, processos de assimilação, reconhecimento de fases minerais fracionadas, diferenciação de suítes magmáticas, dentre outros. Neste estudo, a análise de elementos traço foi realizada por fluorescência de raios $\mathrm{X}$ e espectrometria de massa por plasma acoplado indutivamente ("Inductively coupled plasma mass spectrometry" - ICP-MS).

Diferentemente das concentrações totais dos elementos traço, as razões isotópicas usualmente não sofrem fracionamentos durante processos de fusão e cristalização magmática. Sendo assim, o estudo dos isótopos radiogênicos é de grande importância na compreensão de processos petrogenéticos em rochas ígneas, uma vez que podem caracterizar a fonte mantélica envolvida na geração do magma e permitir o reconhecimento de suítes cogenéticas, desde que nenhum processo de metassomatismo, mistura entre magmas de fontes distintas ou assimilação de material crustal tenha ocorrido durante a formação da rocha (Wilson, 1989). Além disso, a influência de cada um desses processos pode ser reconhecida e quantificada por meio do estudo das razões isotópicas. Na presente investigação foram determinadas as razões isotópicas de $\mathrm{Sr}, \mathrm{Nd}$ e $\mathrm{Pb}$ por espectrometria de massa termoiônica.

As características microtexturais e mineralógicas gerais de cada um dos diques, por sua vez, foram analisadas no microscópio óptico, enquanto que fases muito finas ou não identificadas foram melhor investigadas em microscópio eletrônico de varredura (MEV), acoplado a um espectrômetro de energia dispersiva (EDE). Essas análises foram essenciais para a interpretação dos dados de datação de alguns diques, efetuada pelo método ${ }^{40} \mathrm{Ar} /{ }^{39} \mathrm{Ar}$.

\subsection{Fluorescência de Raios-X}

A FRX é utilizada não apenas na determinação de concentrações de elementos maiores, mas também de elementos menores, uma vez que as análises atingem boa 
precisão desde altas concentrações (da ordem de 100\%), até a ordem de $\mu \mathrm{g} / \mathrm{g}$. O método é vantajoso por conta de sua rapidez, sensibilidade, acurácia e baixos custos em comparação a outros métodos de análise geoquímica. A técnica, não-destrutiva, tem como base o princípio de que, quando expostos a feixes de raios- $\mathrm{X}$, átomos de diferentes elementos químicos emitem feixes secundários com comprimentos de onda característicos (Rollinson, 1993; Al-Merey et al., 2005).

Raios- $X$ consistem em radiações eletromagnéticas de comprimento de onda entre 0,005 e $10 \mathrm{~nm}$, as quais são capazes de interagir com elétrons da eletrosfera dos átomos e afetar as propriedades elétricas de gases, líquidos e sólidos. As fontes de raios-X precisam garantir fluxos contínuos de fótons em um amplo intervalo de frequências, com baixas razões sinal/ruído, e consistem geralmente em tubos de raios-X. Neste caso, elétrons provenientes de metais como Ródio, Molibdênio, Cobre e Tungstênio são acelerados via aplicação de alta voltagem entre um cátodo e um ânodo, e emitem radiação ao colidirem com o último. O tipo de material envolvido, a voltagem, a corrente no tubo e a interferência do espectro do ânodo precisam ser bem conhecidos para a aplicação de correções nas medidas finais (Al-Merey et al., 2005).

A emissão de radiações características de raios-X secundários nas amostras investigadas está associada a transições de elétrons nos orbitais atômicos após a ejeção de elétrons dos níveis mais internos ( $\mathrm{K}$ e $\mathrm{L}$ ), devido à radiação primária incidida. As vacâncias resultantes são preenchidas por elétrons de níveis superiores, e a emissão de radiação secundária é necessária para equilibrar a energia do elétron em trânsito ao novo orbital. O espectro de comprimentos de onda de cada elemento químico exposto a esse processo é característico, uma vez que a disposição de seus elétrons é específica (Markowicz, 2002).

A intensidade de cada um dos comprimentos de onda é detectada e utilizada no cálculo das concentrações dos elementos presentes no material analisado. As correções em função de deriva do equipamento e da influência da composição da amostra são efetuadas através de calibrações que utilizam materiais de referência. Nesse contexto, é importante garantir a homogeneidade do material analisado, o que é atingido via fusão em boratos para elementos maiores; este processo, no entanto, promove diluição da amostra. Por esta razão, a fusão não pode ser empregada na determinação de elementos traço; neste caso são confeccionadas pastilhas prensadas, utilizando a 
amostra pulverizada misturada com um pouco de cera para dar liga (Nardy, 1996; AlMerey et al., 2005).

\subsection{Espectrometria de massa por plasma acoplado indutivamente}

A comercialização da técnica foi iniciada em 1983 e rapidamente alastrou-se por diversos laboratórios do mundo em função de sua capacidade em realizar medições de concentrações de diversos elementos simultaneamente, além de executar análises isotópicas rapidamente. O método atinge alta precisão e acurácia em um grande espectro de concentrações, que podem chegar a valores tão pequenos quanto pg/g. As amostras podem ser analisadas em estado sólido, líquido (mais comum) ou gasoso e, apesar de existirem diversas configurações para a aplicação do método, de maneira geral, a seqüência mais comum de componentes necessários consiste em nebulizador, câmara pulverizadora, tocha de quartzo, e detector (Thomas, 2004).

Para o caso de análises em estado líquido (utilizadas neste estudo), a amostra é dissolvida em meio ácido de acordo com metodologias padrão de dissolução de silicatos, e é introduzida no nebulizador em fluxo da ordem de $1 \mathrm{~mL} /$ minuto, juntamente com gás argônio, onde é convertida em aerossol via aplicação de baixas pressões. Nesse estágio, cerca de 1-2\% da amostra fica contida na porção mais fina do aerossol, e é esta porção que deve ser selecionada na câmara pulverizadora, onde as gotículas maiores ficam retidas por serem inadequadas à ionização via plasma (Rollinson, 1993; Thomas, 2004). Dentro da tocha horizontal de quartzo, o plasma é gerado por meio de um fluxo tangencial de argônio (cerca de $15 \mathrm{~L} / \mathrm{min}$ ) submetido a um campo magnético produzido continuamente por bobinas de cobre com correntes de radiofrequências de 27 ou 40 MHz. A injeção de descargas elétricas inicia a liberação de elétrons internos do próprio fluxo de argônio, e acarreta ionização em cadeia de diversos átomos, gerando plasma de alta temperatura (até $10000 \mathrm{~K}$ ). A colisão entre tais partículas eletricamente carregadas e os átomos das amostras inseridas é responsável pela produção de íons, geralmente de carga positiva (Thomas, 2004).

Todo o processo descrito anteriormente é realizado sob pressão atmosférica. A transição para o espectrômetro precisa ser cuidadosamente efetuada, uma vez que as contagens de íons discretizados pela razão massa/carga precisam ser efetuadas em ambiente de alto vácuo. Após a ionização, as partículas da amostra são encaminhadas a 
uma interface de vácuo intermediário, e, finalmente, por meio da aplicação de uma série de lentes eletrostáticas, são introduzidas na linha do espectrômetro, cujo funcionamento será descrito na seção a seguir.

\subsection{Isótopos de $\mathrm{Sr}, \mathrm{Nd}$ e Pb e Espectrometria de Massa Termoiônica}

O sistema isotópico $\mathrm{Rb}$-Sr foi um dos aplicados neste trabalho. O Rb, um metal alcalino (grupo IA) de raio iônico semelhante ao do K (o que permite sua inclusão em redes cristalinas portadoras do último), apresenta comportamento incompatível durante processos de cristalização fracionada. Seu isótopo radioativo, $0{ }^{87} \mathrm{Rb}$, decai para 0 ${ }^{87} \mathrm{Sr}$ pela emissão de uma partícula $\beta$ negativa:

$$
{ }_{37}^{87} R b \rightarrow{ }_{38}^{87} \mathrm{Sr}+\beta^{-}+\bar{v}+Q
$$

Onde $\beta^{-}$é a partícula $\beta, \bar{v}$ um antineutrino e $Q$ a energia de decaimento (Wilson, 1989; Faure \& Mensing, 2005).

O Sr, por sua vez, é um elemento do grupo dos metais alcalinos terrosos (IIA), e todos os seus isótopos são estáveis. Seu raio iônico é semelhante ao do $\mathrm{Ca}$, o que faz com que, durante a cristalização fracionada, seu comportamento seja mais compatível. Desta forma, durante a evolução magmática, a razão $\mathrm{Rb} / \mathrm{Sr}$ de rochas cogenéticas tende a aumentar, ainda que suas razões iniciais de $\mathrm{Sr}$ sejam iguais se o sistema tiver permanecido fechado (Wilson, 1989). As razões isotópicas atuais ("present-day") de Sr de uma rocha são influenciadas pela sua idade de cristalização (fechamento do sistema) e por sua razão $\mathrm{Rb} / \mathrm{Sr}$, de acordo com a relação:

$$
{ }^{87} \mathrm{Sr} /{ }^{86} \mathrm{Sr}=\left({ }^{87} \mathrm{Sr} /{ }^{86} \mathrm{Sr}\right) \text { inicial }+{ }^{87} \mathrm{Rb} /{ }^{86} \mathrm{Sr}\left(e^{\lambda t}-1\right)
$$

Onde $t$ é a idade da amostra considerada e $\lambda$ a constante de decaimento do ${ }^{87} \mathrm{Rb}$, sendo que as razões ${ }^{87} \mathrm{Sr} /{ }^{86} \mathrm{Sr}$ e ${ }^{87} \mathrm{Rb} /{ }^{86} \mathrm{Sr}$ são medidas em laboratório. (Faure \& Mensing, 2005).

O sistema isotópico $\mathrm{Sm}-\mathrm{Nd}$ das amostras também foi analisado. Ambos os elementos são da série dos lantanídeos (elementos terras raras) e, embora tenham comportamento incompatível, o coeficiente de partição global do $\mathrm{Nd}$ é ainda menor que o do Sm em processos de evolução magmática, o que torna seu padrão oposto àquele do sistema $\mathrm{Rb}-\mathrm{Sr}$, ou seja, quanto mais diferenciadas forem as rochas, menores serão 
suas razões $\mathrm{Sm} / \mathrm{Nd}$. O isótopo ${ }^{147} \mathrm{Sm}$ é radioativo, e decai para o isótopo ${ }^{143} \mathrm{Nd}$ pela emissão de partícula $\alpha$ :

$$
{ }_{62}^{147} \mathrm{Sm} \rightarrow{ }_{60}^{143} \mathrm{Nd}+{ }_{2}^{4} \mathrm{He}+\mathrm{Q}
$$

Onde ${ }_{2}^{4} \mathrm{He}$ representa a partícula $\alpha$ liberada e Q é a energia de decaimento (Wilson, 1989; Faure \& Mensing, 2005).

De modo semelhante ao caso anterior, a abundância do isótopo radiogênico ${ }^{143} \mathrm{Nd}$ depende da idade da amostra e de sua razão $\mathrm{Sm} / \mathrm{Nd}$ :

${ }^{143} N d /{ }^{144} N d=\left({ }^{143} N d / 144 N d\right)$ inicial $+{ }^{147} S m / 144 N d\left(e^{\lambda t}-1\right)$

Onde $\lambda$, no caso, é a constante de decaimento do isótopo ${ }^{147} \mathrm{Sm}$ (Faure \& Mensing, 2005).

Por fim, análises de isótopos de $\mathrm{Pb}$ também foram efetuadas. Sua composição isotópica é influenciada por três séries de decaimento distintas, provenientes de isótopos de $\mathrm{U}$ e Th:

$$
\begin{aligned}
& { }_{92}^{238} \mathrm{U} \rightarrow{ }_{82}^{206} \mathrm{~Pb}+8_{2}^{4} \mathrm{He}+6 \beta^{-}+Q_{206} \\
& { }_{92}^{235} \mathrm{U} \rightarrow{ }_{82}^{207} \mathrm{~Pb}+7{ }_{2}^{4} \mathrm{He}+4 \beta^{-}+Q_{207} \\
& { }_{92}^{232} \mathrm{Th} \rightarrow{ }_{82}^{208} \mathrm{~Pb}+6{ }_{2}^{4} \mathrm{He}+4 \beta^{-}+Q_{208}
\end{aligned}
$$

Nas quais $Q$ representa as energias de decaimento totais de cada uma das séries. As relações entre as razões isotópicas são descritas por:

$$
\begin{gathered}
{ }^{206} \mathrm{~Pb} /{ }_{204} \mathrm{~Pb}=\left({ }^{206} \mathrm{~Pb} / 204 \mathrm{~Pb}\right)_{\text {inicial }}+{ }^{238} \mathrm{U} / 204 \mathrm{~Pb}\left(e^{\lambda_{206} t}-1\right) \\
{ }^{207} \mathrm{~Pb} /{ }^{204} \mathrm{~Pb}=\left({ }^{207} \mathrm{~Pb} /{ }^{204} \mathrm{~Pb}\right)_{\text {inicial }}+{ }^{235} \mathrm{U} / 204 \mathrm{~Pb}\left(e^{\lambda_{207} t}-1\right) \\
{ }^{208} \mathrm{~Pb} /{ }^{204} \mathrm{~Pb}=\left({ }^{208} \mathrm{~Pb} /{ }^{204} \mathrm{~Pb}\right)_{\text {inicial }}+{ }^{232} \mathrm{Th} / 204 \mathrm{~Pb} \\
\end{gathered}
$$

Nas quais $\lambda$ representa a constante de decaimento de cada um dos isótopos radioativos ${ }^{238} \mathrm{U},{ }^{235} \mathrm{U}$ e ${ }^{232} \mathrm{Th}$; Faure \& Mensing, 2005).

Tanto o U quanto o Th são elementos da série dos actinídeos, e possuem configurações eletrônicas, propriedades químicas e raios iônicos semelhantes, ainda que a mobilidade do primeiro seja maior em ambientes oxidantes. $U$, Th e $\mathrm{Pb}$ são elementos incompatíveis e tendem a se concentrar nas fases líquidas envolvendo fusão parcial e cristalização fracionada. 
Neste trabalho, as análises isotópicas foram realizadas por meio de espectrometria de massa termoiônica (TIMS). Neste método, é necessário que as amostras sejam previamente pulverizadas, de modo a aumentar sua superfície de contato e, portanto, possibilitar sua dissolução em meio ácido. Tal processo, também denominado "ataque químico", consiste na quebra das estruturas silicáticas dos minerais constituintes da rocha, e permite a separação individual dos elementos de interesse para análise em espectrômetro de massa. Essa separação é realizada por cromatografia de troca iônica (Kawashita, 1972; Sato, 1995), e o material coletado é depositado em filamentos de Re e Ta. No interior do TIMS, a ionização dos átomos depositados ocorre por conta do aquecimento do filamento e pelo efeito termoiônico resultante.

Todo o procedimento de medição no espectrômetro precisa ser realizado em condições de ultra vácuo, de modo a evitar que as trajetórias das partículas provenientes das amostras sejam perturbadas por moléculas externas e se tornem, portanto, imprevisíveis (Renne, 2000). No interior do tubo do espectrômetro, os íons provenientes do filamento são acelerados por meio da aplicação de uma diferença de potencial, e seguem para uma região curva onde atua um campo magnético perpendicular à trajetória das partículas. A força resultante da interação entre campo e íons em movimento é descrita pela força de Lorentz, e sua ação desvia as trajetórias de acordo com a razão massa/carga de cada partícula, imprimindo-lhes um raio de desvio característico. Dessa maneira, formam-se feixes de partículas discretizados (Vanhaecke, 2012).

Após deixarem a região afetada pelo campo, os feixes são sucessivamente focados e atingem os coletores responsáveis pela medição das correntes. Geralmente, os coletores consistem em Copos de Faraday e Multiplicadores de Elétrons. No primeiro, a corrente de íons é medida por meio da queda de potencial observada ao longo de uma resistência, enquanto no segundo a contagem baseia-se nos elétrons secundários emitidos quando os íons positivos atingem a superfície do multiplicador (McDougall \& Harrison, 1999; Vasconcelos, 2002). 


\subsection{Microscopia Eletrônica de Varredura e Espectroscopia Dispersiva de Energia}

No MEV, as imagens são produzidas pela interação entre as amostras e um feixe de elétrons, que ocasiona emissão de elétrons retroespalhados. Tais emissões secundárias permitem a investigação de diferentes fases minerais, já que suas intensidades são influenciadas pelo número atômico e distribuição espacial dos elementos presentes nas redes cristalinas (altos valores de número atômico estão associados a um retroespalhamento de elétrons mais eficiente do que baixos valores). Essas diferenças de comportamento geram contrastes entre minerais e entre regiões de minerais zonados.

A análise por EDE, por sua vez, permite investigação ainda mais detalhada de fases minerais e variações internas de composição, e consiste na detecção do espectro de raios-X gerado pela excitação dos elétrons nas amostras. Tal excitação é promovida por choques inelásticos entre os elétrons do feixe e os componentes atômicos. A colisão entre elétrons e núcleons ocasiona emissão de raios-X denominados "contínuos", enquanto que ejeções e substituições de elétrons de camadas internas da eletrosfera são responsáveis pelos raios- $X$ "característicos", relacionados às diferenças energéticas entre orbitais. Cada elemento químico apresenta um padrão particular para as emissões de raios- $X$, apresentando picos de contagens em quantidades específicas de energia, acima do ruído de baixas amplitudes composto pelos raios-X contínuos. Por meio dessa propriedade, torna-se possível a identificação da composição de uma zona selecionada para investigação (Hafner, 2007).

\subsection{Geocronologia pelo método ${ }^{40} \mathrm{Ar} /{ }^{\beta 9} \mathrm{Ar}$}

A datação ${ }^{40} \mathrm{Ar} /{ }^{39} \mathrm{Ar}$ foi desenvolvida a partir do método $\mathrm{K}-\mathrm{Ar}$; ambos os métodos baseiam-se no mesmo decaimento radioativo e requerem as mesmas condições para que seus resultados sejam válidos. O isótopo ${ }^{40} \mathrm{~K}$ apresenta meia-vida de $1250 \mathrm{Ma}$, e decai para os isótopos ${ }^{40} \mathrm{Ca}$ e ${ }^{39} \mathrm{Ar}$ :

$$
\begin{gathered}
{ }^{40} \mathrm{~K} \stackrel{\text { Eletrônica }}{\stackrel{\text { Elura }}{\longrightarrow}}{ }^{40} \mathrm{Ar} \\
{ }^{40} \mathrm{~K} \stackrel{\beta^{-}}{\rightarrow}{ }^{40} \mathrm{Ca}
\end{gathered}
$$

Um aspecto importante do comportamento dos átomos de Ar em magmas de alta temperatura é a sua tendência a equilibrar-se com valores atmosféricos - em geral, 
através da exposição do magma a fluidos hidrotermais em equilíbrio ou próximos dos valores encontrados na atmosfera. Isto implica que a composição isotópica inicial de $\mathrm{Ar}$ em minerais de rochas ígneas deve se aproximar destes mesmos valores, desde que total equilíbrio tenha sido alcançado, e que todo conteúdo prévio de ${ }^{40} \mathrm{Ar}$ radiogênico tenha sido liberado. A acumulação deste último em materiais geológicos se inicia após o resfriamento e cristalização dos minerais, e consiste no princípio básico das datações K-Ar e ${ }^{40} \mathrm{Ar} /{ }^{39} \mathrm{Ar}$.

Em baixas profundidades, as baixas temperaturas permitem que o Ar radiogênico permaneça aprisionado na estrutura cristalina dos minerais portadores de $\mathrm{K}$ em decorrência de seu grande raio iônico e, uma vez que a taxa de decaimento do ${ }^{40} \mathrm{~K}$ e as concentrações de ${ }^{40} \mathrm{~K}$ e ${ }^{40} \mathrm{Ar}$ de um mineral ou rocha são conhecidas, é possível calcular a sua idade (McDougall \& Harrison, 1999). O valor calculado será equivalente ao tempo desde a temperatura de bloqueio do mineral ou conjunto de minerais analisado, desde que nenhum processo de transporte de Ar tenha atuado no sistema (regime fechado). Ambos os métodos $\mathrm{K}-\mathrm{Ar}$ e ${ }^{40} \mathrm{Ar} /{ }^{39} \mathrm{Ar}$ são muito versáteis por conta da presença de minerais portadores de $\mathrm{K}$ em vários tipos de rocha, e também pela alta sensibilidade de equipamentos modernos para a detecção de Ar radiogênico, o que permite a datação tanto de amostras muito jovens (poucos milhões de anos), quanto muito antigas (McDougall \& Harrison, 1999; Renne, 2000).

A relação de proporcionalidade entre a taxa de decaimento de um elemento radioativo e seu número de átomos permite chegar à seguinte relação entre os conteúdos de ${ }^{40} \mathrm{Ar},{ }^{40} \mathrm{~K}$ e o tempo desde o fechamento do sistema:

$$
t=1 / \lambda_{\lambda} \ln \left[1+\left(\lambda_{\text {Ar }} / \lambda_{\text {total }}\right)^{40} A r^{*} /{ }^{40} K\right]
$$

Onde ${ }^{40} A r^{*}$ é o conteúdo de ${ }^{40} \mathrm{Ar}$ radiogênico, $\lambda_{A r}$ é a constante de decaimento do isótopo ${ }^{40} \mathrm{~K}$ para o isótopo ${ }^{40} \mathrm{Ar}$, $\lambda_{\text {total }}$ é a constante de decaimento total do isótopo ${ }^{40} \mathrm{~K}$, e $t$ o tempo desde o fechamento do sistema.

Tanto o método K-Ar quanto o ${ }^{40} \mathrm{Ar} /{ }^{39} \mathrm{Ar}$ pressupõem que as seguintes condições sejam satisfeitas:

I. A taxa de decaimento do K é constante e não é afetada por mudanças de pressão ou temperatura;

II. A composição isotópica do $\mathrm{K}$ na natureza é constante em qualquer época; 
III. O conteúdo de ${ }^{40} \mathrm{Ar}$ foi originado in situ a partir do decaimento do ${ }^{40} \mathrm{~K}$ desde a cristalização;

IV. Em rochas terrestres, o Ar presente antes da cristalização esteve em equilíbrio com a composição atmosférica de Ar, o que permite correções para o ${ }^{40} \mathrm{Ar}$ não radiogênico;

V. O sistema permaneceu fechado desde o resfriamento do evento termal cuja idade é investigada (não ocorreu difusão de K ou de Ar desde então).

Tais suposições são melhor examinadas quando diferentes fases minerais são investigadas. Além disso, a datação ${ }^{40} \mathrm{Ar} /{ }^{39} \mathrm{Ar}$ pode fornecer informações adicionais a essa investigação (McDougall \& Harrison, 1999).

$\mathrm{O}$ método ${ }^{40} \mathrm{Ar} /{ }^{39} \mathrm{Ar}$ é baseado na interação entre feixes de nêutrons rápidos $(>1 \mathrm{MeV})$ e o isótopo ${ }^{39} \mathrm{~K}$ em reatores nucleares, através da qual átomos do isótopo ${ }^{39} \mathrm{Ar}$ são gerados por meio da emissão de prótons, de acordo com a reação:

$$
{ }_{19}^{39} \mathrm{~K}+{ }_{0}^{1} n={ }_{18}^{39} \mathrm{Ar}+{ }_{1}^{1} \mathrm{H}+0.22 \mathrm{MeV} \text {, ou }{ }^{39} \mathrm{~K}(n, p){ }^{39} \mathrm{Ar}
$$

Sendo assim, o conteúdo de ${ }^{39} \mathrm{Ar}$ de uma amostra irradiada reflete seus teores iniciais de ${ }^{39} \mathrm{~K}$, e, consequentemente, de ${ }^{40} \mathrm{~K}$, ou seja, a razão ${ }^{40} \mathrm{Ar} * /{ }^{39}$ Aré proporcional à razão ${ }^{40} \mathrm{Ar}^{*} /{ }^{40} \mathrm{~K}$ da amostra e pode, assim, ser usada no cálculo de sua idade. A interação entre nêutrons e isótopos ${ }^{39} \mathrm{~K}$ durante a irradiação precisa ser incluída no cálculo das idades aparentes, e é expressa pelo parâmetro J:

$$
t=\frac{1}{\lambda} \ln \left(1+J \frac{{ }^{40} A r^{*}}{{ }^{39} A r}\right)
$$

O valor de J pode ser obtido a partir do uso de minerais de monitoramento de fluxo, ou seja, padrões cuja idade foi previamente bem determinada e que são irradiados simultaneamente às amostras de interesse. Como sua idade é conhecida, o valor de J pode ser determinado após a medição de suas razões ${ }^{40} \mathrm{Ar} * /{ }^{39} \mathrm{Ar}$ (Mitchell, 1968; Alexander \& Davis, 1974; McDougall\& Harrison, 1999; Vasconcelos, 2002). O valor J obtido é, posteriormente, utilizado para o cálculo de idades aparentes/integradas das outras amostras da mesma irradiação.

Uma das vantagens desta metodologia em relação à datação K-Ar é que tal razão isotópica é determinada em uma única medição por espectrometria de massa, a partir de uma única alíquota da amostra, o que diminui fontes de incertezas e riscos de heterogeneidades. Além disso, este tipo de análise exige quantidades muito menores 
de material por conta de sua alta sensibilidade, alcançando precisão muito maior. Outra grande vantagem do método é a possibilidade de aquecimento gradual da amostra durante a liberação do gás em ambiente de ultra vácuo, o que permite que a análise da razão ${ }^{40} \mathrm{Ar} * /{ }^{39} \mathrm{Ar}$ ocorra em cada um dos níveis de temperatura - técnica denominada de aquecimento por etapas ("incremental step heating"). A série de idades aparentes obtidas para cada passo costuma ser plotada em função da porcentagem de ${ }^{39} \mathrm{Ar}_{\mathrm{K}}$ liberado, o que gera o diagrama de espectro de idades característico da amostra, uma ferramenta essencial na análise da confiabilidade da idade integrada obtida, da validade das premissas do método, e também na investigação da história térmica da amostra (McDougall \& Harrison, 1999; Renne, 2000; Vasconcelos, 2002).

A principal limitação do método ${ }^{40} \mathrm{Ar} /{ }^{39} \mathrm{Ar}$ é a necessidade de uma quantidade mínima de gás para que as idades aparentes sejam calculadas de maneira precisa; essa quantidade depende da sensibilidade do espectrômetro de massa e da razão sinal/ruído da análise. $\mathrm{O}$ aquecimento da amostra pode ser realizado por diferentes técnicas; uma das mais comuns é a irradiação por feixes contínuos de laser. Tal metodologia permite análises em um único grão ou em agregados, e sua eficácia depende da absorbância característica da fase mineral (ou fases minerais) analisada, e da densidade de intensidade incidente do laser. Por tais fatores, torna-se necessário escolher tipos de laser e níveis de intensidade particulares para cada análise (McDougall \& Harrison, 1999).

Átomos de $\operatorname{Ar}$ e outros componentes voláteis dos minerais analisados são liberados gradualmente via processos de difusão conforme a intensidade do feixe de laser é aumentada, até que o material seja totalmente fundido. Antes das análises dos isótopos de Ar por meio de espectrometria de massa, é importante isolá-los de outros gases ativos, de modo a evitar efeitos de dispersão dentro da linha do espectrômetro, o que geralmente é alcançado por meio da indução de reações que incorporam tais gases. O Ar e os gases nobres restantes são direcionados ao filamento emissor de elétrons para ionização via bombardeamento. A retirada de gases ativos também é importante para evitar a oxidação deste filamento. 


\section{PROCEDIMENTO EXPERIMENTAL}

\subsection{Trabalhos de amostragem}

As amostras dos diques investigados foram coletadas ao longo da zona litorânea da Região dos Lagos, no Estado do Rio de Janeiro, passando pelos municípios de Arraial do Cabo, Cabo Frio e Armação dos Búzios. Vinte e dois diques foram amostrados, sendo que doze deles haviam sido previamente investigados em estudos de paleomagnetismo; os dez corpos novos também foram amostrados para estudos paleomagnéticos nos trabalhos de campo. Durante a seleção dos diques, procurou-se privilegiar corpos de maior espessura (acima de 1 metro) e com pouco ou nenhum sinal de intemperização. A amostragem foi realizada na região central dos diques, de modo ao evitar contaminação com as rochas encaixantes. A localização das amostras é indicada no mapa da figura 4.1.

\subsection{Preparação das amostras para análises geoquímicas e isotópicas}

O trabalho de preparação das amostras do presente estudo foi precedido de um estudo comparativo de protocolos de preparação de rochas para análises de $\mathrm{Pb}$. Tal teste experimental mostrou-se necessário em função das muitas variantes metodológicas encontradas na literatura que trata do magmatismo Paraná-Etendeka. Dados de concentração e de razões isotópicas de $\mathrm{Pb}$ são fundamentais no entendimento e modelagem de processos petrogenéticos, envolvendo a caracterização de fontes mantélicas, como também na identificação e quantificação de processos de assimilação/contaminação crustal e mistura de magmas. Entretanto, a falta de informações sobre os métodos de preparação das amostras dificultava a seleção e comparação de dados de diferentes laboratórios e grupos de pesquisa, já que pouco se conhecia acerca dos efeitos da inclusão ou ausência de cada etapa da preparação.

O teste experimental encontra-se descrito a seguir e também em Marques et al. (2016). 


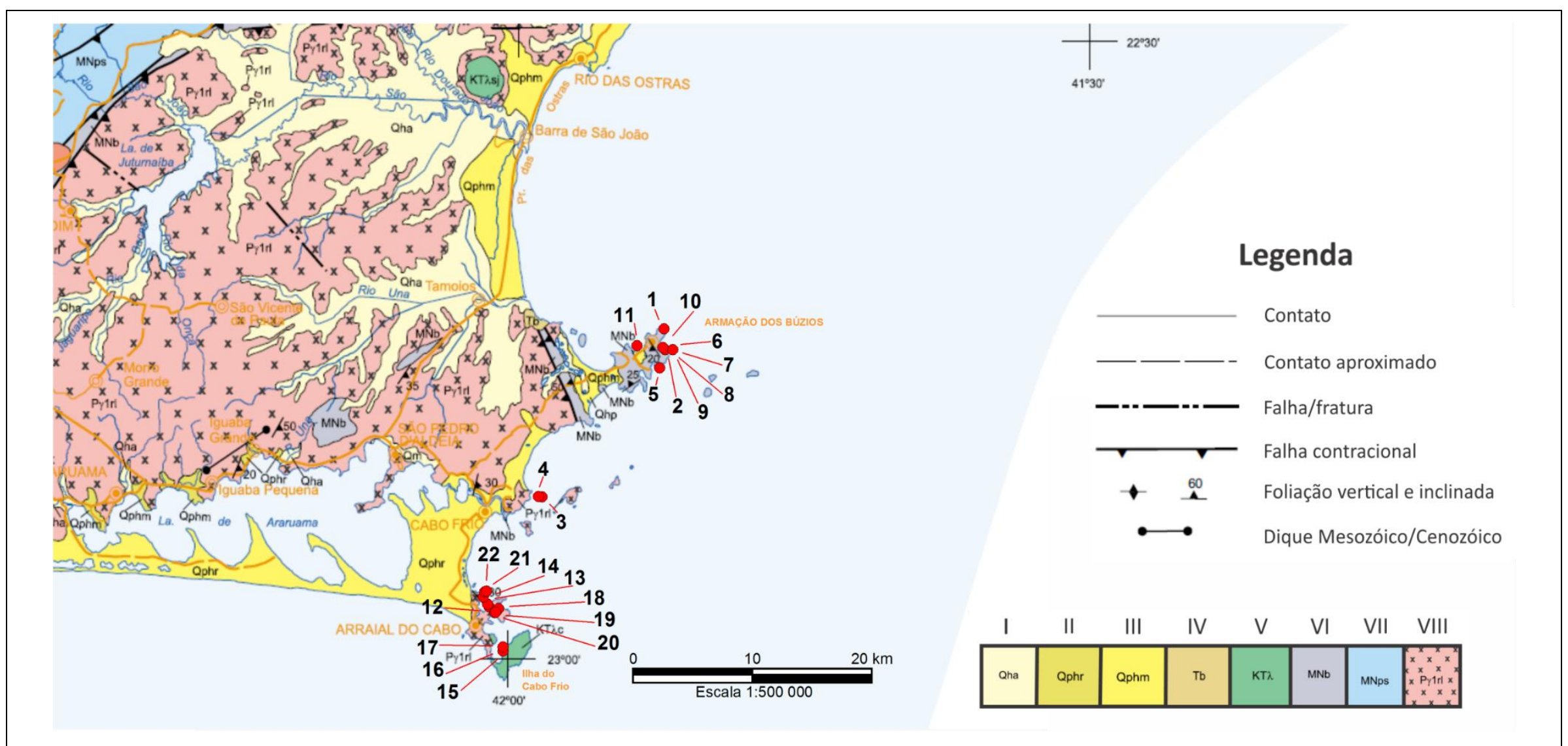

Figura 5.1: Mapa geológico da Região dos Lagos (RJ) e localização dos diques amostrados. 1-(LM-DA-)200; 2-206; 3-203; 4-204; 5-205; 6-BZ-4R; 7-BZ-5R; 8-6R; 9-BZ15N; 10-207; 11-208; 12-158; 13-161; 14-209; 15-210; 16-183; 17-182; 18-211; 19-155; 20-212; 21-152; 22-150. I (Qha) - Depósito Colúvio-Aluvionar areno-sílticoargiloso (Quaternário); II (Qphr) - Depósito Marinho e Flúvio-Marinho síltico-areno-argiloso (Quaternário); III (Qphm) - Depósito de Restinga de areias quartzosas (Quaternário); IV (Tb) - Grupo Barreiras, depósito detrítico de cascalhos, argilo-arenoso (Terciário); V (KT $\lambda$ ) - Rochas alcalinas (Cretáceo/Terciário); VI (MNb) - Complexo Búzios, com cianita-sillimanita-granada-biotita xistos e gnaisses quartzo-feldspáticos (Meso/Neoproterozoico); VII (MNps) - Complexo Paraíba do Sul, com cianitasillimanita-granada-biotita xistos (Meso/Neoproterozoico); VIII (P 1 rl) - Complexo Região dos Lagos, com hornblenda-biotita ortognaisses calci-alcalinos (Paleoproterozoico). Fonte: “Mapa Geológico do Estado do Rio de Janeiro” (CPRM e DRM-R, 2000). 


\subsubsection{Protocolo de preparação de amostras para análises de $P b$}

Análises de $\mathrm{Pb}$ exigem cautela, já que podem ser afetadas por contaminações com $\mathrm{Pb}$ presente nos materiais usados na pulverização e entre amostras (contaminação cruzada; Marques et al., 1999). O protocolo de preparação aplicado no Centro de Pesquisas Geocronológicas da Universidade de São Paulo (CPGeo-USP), onde todas as análises isotópicas deste trabalho foram realizadas, foi trazido do Institut de Physique du Globe de Paris (IPGP), e consiste nas etapas descritas na tabela 5.1.

Tabela 5.1: Etapas do protocolo de preparação utilizado no CPGeo-USP.

\begin{tabular}{|c|c|}
\hline Etapa & Descrição \\
\hline I & Remoção de superfícies serradas e alteradas e britagem. \\
\hline II & Lavagem em água destilada e quarteamento. \\
\hline III & Lavagem em ácido nítrico purificado (0,1M) e água deionizada (milli-Q) em \\
IV & ultrassom. \\
\hline
\end{tabular}

Durante as etapas I e IV, após a limpeza dos utensílios necessários, uma alíquota minoritária da amostra trabalhada foi descartada, e a alíquota restante, utilizada nas análises, foi preparada após nova limpeza de todos os apetrechos. Este procedimento tem como objetivo evitar contaminações cruzadas entre amostras preparadas em sequência.

O primeiro objetivo do teste experimental consistiu na avaliação da necessidade de lavagem dos fragmentos com ácido nítrico diluído (etapa III). Originalmente, o protocolo descrito acima era destinado à análise de basaltos oceânicos, nos quais incrustações carbonáticas e de sulfetos são muito comuns e exigem a lixiviação dos fragmentos. Em amostras de ambiente próximo à linha da costa, como as deste trabalho, a real necessidade deste procedimento era pouco avaliada.

Já na última etapa (IV), durante o procedimento de pulverização, a fricção entre o material que compõe o moinho e as amostras pode ocasionar contaminações significativas. O WC é atualmente utilizado no CPGeo por sua dureza, e por não ocasionar contaminações de $\mathrm{Pb}$; entretanto, ele altera expressivamente concentrações 
de elementos como o Os, W, Ta e Co e, assim, não pode ser utilizado para análises de elementos-traço. Nestas, usualmente, o material mais utilizado é ágata, que, além de não interferir nas concentrações dos elementos supracitados, é de mais fácil manuseio. O segundo objetivo do teste experimental consistiu em quantificar a real influência do uso de moinhos de ágata em amostras com variadas concentrações de $\mathrm{Pb}$, de modo a definir se seu uso poderia ser generalizado à preparação de amostras para análises geoquímicas e isotópicas.

O estudo comparativo foi realizado em duas etapas. Um teste inicial foi realizado em Carvas (2013), com base em uma amostra de teor relativamente alto de $\mathrm{Pb}$ $([\mathrm{Pb}] \approx 8 \mu \mathrm{g} / \mathrm{g})$, no qual as análises de alíquotas pulverizadas em ágata, com e sem lixiviação (lavagem com ácido nítrico diluído), foram comparadas àquelas obtidas usando o protocolo de preparação padrão. Todos os resultados foram compatíveis, dentro dos limites das incertezas analíticas; no entanto, ainda era incerto se a alta concentração de $\mathrm{Pb}$ da amostra escolhida, um dique subalcalino com alto Ti do Enxame da Serra do Mar, seria capaz de mascarar pequenas contaminações relacionadas às modificações de protocolo.

Dessa forma, neste trabalho, foram realizados testes adicionais em 3 amostras de derrames da PMP, cuja localização e análises geoquímicas encontram-se em Piccirillo \& Melfi (1988) e Marques et al. (1989): BCP-512 (de concentrações de Pb inicialmente

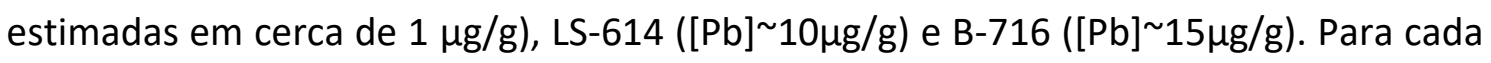
uma das amostras, foram preparadas alíquotas seguindo os seguintes procedimentos: protocolo padrão, com lixiviação e pulverização em moinho de WC do CPGeo-USP (P); lixiviação e pulverização em moinho de WC do IAG-USP (CL-C); lixiviação e pulverização em moinho de ágata do IAG-USP (CL-A); apenas pulverização em moinho de WC do IAGUSP (SL-C); apenas pulverização em moinho de ágata do IAG-USP (SL-A). As alíquotas preparadas com o moinho de WC do laboratório de Geofísica Nuclear do IAG-USP tiveram como intuito comparar resultados de ambos os laboratórios de preparação.

Todos os procedimentos foram realizados no laboratório de Geofísica Nuclear do IAG-USP, com exceção da lavagem em ácido nítrico e água milli-Q em ultrassom e parte das pulverizações em WC, que foram realizadas no CPGeo-USP. Por conta dos altos custos das análises, apenas a amostra $\mathrm{B}-512$, de menor teor de $\mathrm{Pb}$, teve todas as alíquotas analisadas. Para a amostra LS-614, foram analisadas as alíquotas P, CL-A, e SL- 
A, enquanto para a B-716, foram selecionadas somente as alíquotas $P$ e SL-A. Posteriormente, foi realizado o processamento químico das alíquotas selecionadas no laboratório limpo do CPGeo-USP, com base nos procedimentos descritos em Marques et al. (1999; 2003; 2016). Todos os ácidos utilizados durante os procedimentos foram previamente purificados. A primeira etapa consistiu em ataque químico (dissolução) de $100 \mathrm{mg}$ da amostra pulverizada com ácido nítrico e ácido fluorídrico concentrados em chapa clean-box $\left(110^{\circ} \mathrm{C}\right)$, por cerca de 10 dias, para promover a quebra total das estruturas silicáticas. Após esse período, as amostras foram submetidas à secagem e à adição posterior de ácido clorídrico $6 \mathrm{M}$, voltando a ser aquecidas em chapa $\left(110^{\circ} \mathrm{C}\right)$ por um dia. Seguiu-se com nova dissolução em $\mathrm{HBr}$ 0,7M e nova evaporação.

Anteriormente à passagem das amostras nas colunas aniônicas, para separação de $\mathrm{Pb}$, seus resíduos de secagem foram novamente diluídos em $\mathrm{HBr} 0,7 \mathrm{M}$, o mesmo ácido empregado no condicionamento da resina utilizada, a AG1-X8. A eluição final (coleta dos átomos de $\mathrm{Pb}$ ) foi promovida pela adição de $\mathrm{HCl} 6 \mathrm{M}$. Todo este procedimento foi realizado duas vezes, buscando purificar ao máximo o material final da eluição; após esse processo as amostras foram submetidas à secagem. Em seguida, foram preparados filamentos de Re para deposição, a qual foi realizada após a diluição dos resíduos em $\mathrm{H}_{3} \mathrm{PO}_{4}$ 0,7M.

Por fim, a análise foi realizada em Espectrômetro de Massa de Termoionização (TIMS), modelo Finnigan MAT 262, juntamente à análise em duplicata do padrão NBS981, destinada aos cálculos de discriminação de massa. Medições realizadas em espectrômetros de massa precisam passar por tal correção, já que estão sujeitas a diferenças de sensibilidade de deteç̧ão para diferentes íons (resultantes de variações de eficiência de ionização e transmissão em função do equipamento e do tempo; McDougall \& Harrison, 1999). As razões isotópicas foram corrigidas para fracionamento de massa de 0,095\% /u.m.a, e cerca de 60 medidas foram realizadas por alíquota, de forma a garantir uma boa estatística de dados. O branco analítico obtido foi de 100 pg.

Os resultados do teste descrito atestaram a importância da lavagem em ácido nítrico e água Milli-Q em amostras de baixo teor de $\mathrm{Pb}$, e evidenciaram que o uso de moinhos de ágata não acarreta contaminações nos valores de concentração e razões isotópicas, conforme reportado em Marques et al. (2016). De acordo com trabalhos anteriores (Bennio et al., 2003; Corval, 2007), os diques investigados neste trabalho 
apresentam características semelhantes à amostra BCP-512 (basalto com concentrações relativamente baixas de $\mathrm{Ti}$ e elementos traço incompatíveis), altamente susceptível a contaminações. Tendo isto em vista, a preparação dos fragmentos dos diques para as análises foi guiada pelos resultados deste teste, e incluiu, assim, a pulverização em moinho de ágata e lixiviação.

\subsubsection{Preparação das amostras da Região dos Lagos}

A preparação dos 22 diques coletados foi destinada às análises de elementos maiores, menores e traços (FRX e ICP-MS), e razões isotópicas de $\mathrm{Sr}, \mathrm{Nd}$ e $\mathrm{Pb}$ (espectrometria de massa termoiônica). Durante a britagem inicial, foi utilizada a prensa hidráulica (EMIC - PCM100C), de forma a atingir fragmentos de dimensões não maiores do que $10 \mathrm{~cm}$. Para cada amostra, a prensa foi previamente limpa com pano úmido; além disso, os blocos de rocha foram envolvidos em filme plástico, de modo a evitar demasiado contado com o equipamento. Posteriormente, a britagem mais fina foi realizada por meio do britador Pulverisette1 (Model II classic - Fritsch), previamente descontaminado com diabásio de um dique do Enxame de Ponta Grossa e cuidadosamente higienizado com jato de ar, esponjas de aço, água destilada e álcool entre cada uma das amostras. Como na preparação dos basaltos do teste experimental, a primeira fração de cada dique passada pelo britador foi descartada para a prevenção contra contaminações cruzadas. Os fragmentos foram reduzidos até atingirem dimensões menores que $0,5 \mathrm{~cm}$.

Após quarteamento, uma fração de cerca de $15 \mathrm{~g}$ de cada amostra foi encaminhada para o Laboratório de Fluorescência de Raios-X do Departamento de Petrologia e Metalogenia da UNESP de Rio Claro, onde foi realizada pulverização em moinho de WC, segundo o protocolo interno. As amostras foram analisadas juntamente aos padrões BHVO-2 e BE-N, obtendo valores de exatidão inferiores a 7,2\% (para os materiais de referência BHVO-2 e BE-N) para os óxidos.

Para as análises de elementos traços por ICP-MS e determinações das razões isotópicas, foram quarteadas cerca de 200 gramas de cada amostra britada, cujos fragmentos foram submetidos à lavagem em ácido nítrico 0,1M (Synth) em ultrassom no Laboratório de Geofísica Nuclear do IAG-USP e, posteriormente, em água deionizada no CPGeo-USP. Após a secagem dos fragmentos em chapa (clean-box) do CPGeo, foram iniciados os trabalhos de pulverização no moinho de anéis de ágata do Laboratório de 
Geofísica Nuclear do IAG-USP, seguindo os resultados do teste experimental. A panela e os anéis foram previamente descontaminados com sílica, lavados com água e detergente, seguido por banho em água destilada sob ultrassom e, finalmente, enxague em álcool. O mesmo procedimento de descarte da fração inicial de pó também foi realizado a cada moagem para evitar a contaminação cruzada. Após o descarte o moinho foi submetido a nova limpeza.

O pó resultante de todo esse procedimento teve parte encaminhada ao Laboratório de Geoquímica do Departamento de Geologia e Recursos Naturais do Instituto de Geociências da UNICAMP, para realização de análise de elementos traço por ICP-MS. O padrão utilizado nas medições foi o BRP-1, e a grande maioria dos resultados atingiu valores de exatidão inferiores ou iguais a $10 \%$ ( 0 - 10\%; valores disponíveis no apêndice B). Exceções a esse comportamento ocorreram com o V (10.2\%), Rb (26.4\%) e $\mathrm{Cr}(46.5 \%)$, motivo pelo qual foram privilegiadas as análises realizadas via FRX (tabela disponível no apêndice A). O mesmo foi realizado para as análises de Sr, que atingem melhor exatidão na metodologia de FRX (Azzone, R. G.; comunicação pessoal). Os valores de branco obtidos para todos os elementos investigados foram inferiores a $3 \%$, ou abaixo do limite de detecção (maioria).

Nove alíquotas, selecionadas com base nos dados de elementos maiores, menores e traços, também foram encaminhadas ao CPGeo-USP para realização das análises de isótopos de $\mathrm{Sr}, \mathrm{Nd}$ e $\mathrm{Pb}$. A seleção procurou compreender amostras representativas dos dois grupos geoquímicos detectados (descritos no capítulo 6). Para estas amostras, todo o processamento químico, deposição e análise no espectrômetro foram realizados pelo corpo técnico do CPGeo-USP. As medições das razões isotópicas de Sr foram realizadas no TIMS - Triton, e normalizadas para o valor de ${ }^{86} \mathrm{Sr} /{ }^{88} \mathrm{Sr}=0,1194$, com branco em 119 pg. O resultado obtido para o padrão NBS-987 foi de 0,710237 \pm 0.000024 (exatidão de 0,0015\%). As de Nd, por sua vez, foram efetuadas no ICP-MS-Thermo Neptune, e normalizadas para ${ }^{146} \mathrm{Nd} /{ }^{144} \mathrm{Nd}=0,7219$ (de acordo com De Paolo, 1981a). O branco atingiu o valor de 40 pg, e o padrão aplicado foi o JNdi-1 (0,512086 $\pm 0,000006$; exatidão de 0,0012\%). Finalmente, para as análises isotópicas de Pb, foi utilizado o TIMS-Finnigan MAT 262, com branco de 142 pg. O padrão empregado foi o NBS-981 $\left({ }^{206} \mathrm{~Pb} /{ }^{204} \mathrm{~Pb}=\right.$ $16,894 \pm 0,006 ;{ }^{207} \mathrm{~Pb} /{ }^{204} \mathrm{~Pb}=15,433 \pm 0,008 ;$ e ${ }^{208} \mathrm{~Pb} /{ }^{204} \mathrm{~Pb}=36,519 \pm 0,024$; exatidões 
de $0,246 \%, 0,362 \%$, e 3,220\%, respectivamente). As razões isotópicas foram corrigidas para fracionamento de 0,13\%/u.m.a.

\subsection{Preparação de amostras para datação ${ }^{40} \mathrm{Ar} /{ }^{39} \mathrm{Ar}$}

\subsubsection{Seleção de amostras}

A seleção de amostras para datação ${ }^{40} \mathrm{Ar} /{ }^{39} \mathrm{Ar}$ baseou-se em análise petrográfica com enfoque no estado de alteração dos minerais, e em dados paleomagnéticos de estudos anteriores (Ernesto et al., 2014). Em função dessas informações preliminares, decidiu-se realizar a datação nos cristais da matriz e em fenocristais de plagioclásio frescos, nas bordas frescas de fenocristais de plagioclásio sericitizados e também nos núcleos sericitizados dos fenocristais. A análise destes últimos destinou-se à investigação da influência da sericita nas idades dos plagioclásios (efeito negligenciado na maior parte dos estudos anteriores), bem como determinar a idade do evento de alteração.

Foram privilegiados, portanto, os diques cujas lâminas apresentaram grande quantidade de fenocristais de plagioclásio frescos ou sericitizados na região central, mas com bordas frescas e, em ambos os casos, com plagioclásios da matriz muito frescos. Amostras que apresentaram plagioclásios com considerável quantidade de fraturas e alterações em piroxênios foram automaticamente descartadas. Finalmente, dentre os diques selecionados, foram privilegiados aqueles cuja polaridade paleomagnética já era conhecida. Quatro das vinte e duas amostras foram selecionadas:

LM-DA-150 - dique de cerca de 2,5 metros de espessura, e polaridade paleomagnética reversa. Seus fenocristais de plagioclásio são afetados por sericitização na zona central, enquanto os cristais da matriz apresentam-se frescos.

LM-DA-161 - dique com 1 metro de espessura e polaridade paleomagnética normal. Os fenocristais de plagioclásio encontram-se, em sua maior parte, frescos, assim como os cristais da matriz.

LM-BZ-5R - dique de cerca de 3 metros de espessura, com diversos diques menores associados, e polaridade reversa. Os fenocristais apresentam-se ora sericitizados, ora frescos, enquanto os plagioclásios da matriz estão, na maior parte das vezes, bem preservados. 
LM-DA-203 - dique de cerca de 20 metros de espessura. Este corpo ainda não possui determinação do polo paleomagnético. A análise petrográfica permitiu identificar cristais de plagioclásio, na maioria das vezes, muito frescos e adequados à datação ${ }^{40} \mathrm{Ar} /{ }^{39} \mathrm{Ar}$.

\subsubsection{Separação de plagioclásio}

Em função das dificuldades em separar a borda fresca dos fenocristais de seu núcleo sericitizado, apenas duas das quatro amostras foram trabalhadas no CPGeo-USP (LM-DA-150 e LM-DA-203), em caráter de teste.

As primeiras etapas de redução granulométrica foram realizadas no Laboratório de Geofísica Nuclear do IAG-USP. Fragmentos dos diques de dimensões não maiores do que $10 \mathrm{~cm}$ foram separados via marreta e prensa hidráulica (EMIC - PCM100C). As superfícies alteradas por intemperismo foram retiradas com o auxílio de mini retífica de alumina $\left(\mathrm{Al}_{2} \mathrm{O}_{3}\right)$. Em seguida, os pedaços foram reduzidos até que os grãos atingissem dimensões de cerca de 0,5 cm, por meio do uso do britador Pulverisette 1 (Model II classic - Fritsch). A descontaminação foi realizada por meio de jato de ar, água destilada e álcool, com descarte da porção inicial de cada amostra passada no britador.

No laboratório de preparação do CPGeo-USP, foi realizada redução granulométrica com pilão de aço inoxidável, e seleção de duas frações utilizando peneiras: 80-150 Mesh (para seleção de fenocristais e cristais da matriz de plagioclásio frescos) e 150-250 Mesh (para seleção de núcleos sericitizados e bordas frescas dos fenocristais de plagioclásio alterados). Em seguida, os grãos foram lavados em ultrassom com água de torneira, e secados sob lâmpadas. Para cada uma das amostras, as duas frações granulométricas foram submetidas à passagem de ímã de mão para retirada de magnetita, seguida de passagem em Frantz em corrente de 0,5 A para retirada da maior parte dos minerais de alta resposta magnética, como os piroxênios. Para realizar a separação dos minerais densos presentes na fração não magnética, foi realizada separação gravimétrica em colunas com bromofórmio puro $\left(2810 \mathrm{~kg} / \mathrm{m}^{3}\right)$, recolhendose o material flutuante (onde o plagioclásio ficou contido). Cabe aqui salientar que todo o material restante de cada separação foi armazenado, com exceção dos grãos de magnetita, que foram desprezados.

O fato de que na maioria dos casos a sericitização ocorre em zonas internas dos grãos de plagioclásio sugere que ela esteja relacionada ao zoneamento composicional. 
De maneira geral, em rochas basálticas, núcleos de fenocristais de plagioclásio são ricos em $\mathrm{Ca}$, enquanto as bordas sofrem enriquecimento progressivo em $\mathrm{Na}$ (Nemec, 1966). A sericitização seletiva, neste caso, pode estar relacionada a processos magmáticos ou pós-magmáticos que envolvem a percolação de fluidos sódico-potássicos, reagentes com as fases mais cálcicas.

A tentativa de separação dos núcleos sericitizados (fração 150-250 Mesh) foi realizada em duas etapas: a) separação gravimétrica em líquido de densidade entre $2650 \mathrm{~kg} / \mathrm{m}^{3}$ e $2670 \mathrm{~kg} / \mathrm{m}^{3}$ (fases sódicas são menos densas que cálcicas, e flutuariam nessa faixa de densidade); b) separação de grãos de sericita dos de plagioclásio cálcico (fase mais densa) por meio do Frantz. A grande dificuldade do processo consistiu na preparação do líquido de separação: a tentativa de diluição do bromofórmio com álcool etílico (96\%; densidade aproximada de $810 \mathrm{~kg} / \mathrm{m}^{3}$ ) mostrou-se ineficaz, uma vez que a água presente no álcool formava aglomerados com as frações finas das amostras e alterava seu comportamento na coluna. Uma segunda tentativa foi realizada utilizando acetona (densidade $790 \mathrm{~kg} / \mathrm{m}^{3}$ ) como solvente, e a densidade da solução precisou ser monitorada constantemente, dada sua alta volatilidade. Ainda que uma fração mais densa tenha colapsado rapidamente, o restante dos grãos permaneceu muito instável dentro das colunas. Os grãos mais densos foram armazenados separadamente, assim como os pouco densos, e os de comportamento intermediário. As três frações de cada uma das duas amostras foram, então, passadas no Frantz com corrente de $1 \mathrm{~A}$.

Durante a análise dos grãos de cada fração em microscópio ótico, verificou-se que muitos plagioclásios contendo sericita, de fato, colapsaram nas colunas de separação; no entanto, as três frações mostraram-se pouco distintas, possuindo tanto plagioclásios frescos quanto alterados. A passagem pelo Frantz a 1 A mostrou-se efetiva na separação de agregados com piroxênios (contidos na fração magnética). Todas as frações discriminadas foram encaminhadas ao Laboratório de Geocronologia de Argônio da Universidade de Queensland (UQ-AGES), Austrália, para a realização das próximas etapas, juntamente a fragmentos das outras duas amostras selecionadas, a LM-DA-161 e a LM-BZ-5R.

5.3.3. Seleção de grãos, encapsulação para monitoramento de recuo e irradiação. No UQ-AGES, grãos de plagioclásio fresco e de plagioclásio sericitizado da fração de 80-150 Mesh das amostras LM-DA-203 e LM-DA-150 foram selecionados em 
microscópio e coletados pela equipe técnica por meio de catação com pinça. Dado que os grãos coletados eram muito pequenos, foi realizada encapsulação das alíquotas em invólucros de sílica de alto vácuo para monitoramento de efeitos de recuo (recoil) de Argônio, efeito diretamente relacionado à interação entre o feixe de nêutrons e os isótopos ${ }^{39} \mathrm{~K}$ durante a irradiação. Tal interação é descrita por:

$$
{ }^{39} A r_{K}={ }^{39} K \Delta \int \phi(E) \sigma(E) d E
$$

Onde $\Delta$ é a duração da irradiação, $\phi(E)$ o fluxo de nêutrons de energia $\mathrm{E}$, e $\sigma(E)$ a secção de choque para captura de nêutrons de energia $E$ (Mitchell et al., 1968). O parâmetro J, calculado por meio da análise de padrões, é definido pela seguinte relação:

$$
J=\frac{{ }^{39} K}{{ }^{40} K}\left(\lambda_{\text {total }} / \lambda_{A r}\right) \Delta \int \phi(E) \sigma(E) d E
$$

A distribuição de energia durante a irradiação das amostras atinge valores entre 0 e $400 \mathrm{KeV}$, e ocasiona recuo médio de $0,08 \mu \mathrm{m}$ dos átomos de ${ }^{39} \mathrm{Ar}$ durante a reação ${ }^{39} \mathrm{~K}(\mathrm{n}, \mathrm{p}){ }^{39} \mathrm{Ar}$ (Turner \& Cadogan, 1974; McDougall \& Harrison, 1999). Este efeito pode alterar consideravelmente a distribuição dos átomos de ${ }^{39} \mathrm{Ar}$ em amostras de granulometria fina e, portanto, anular a premissa de que estes localizam-se em posições equivalentes às originais dos átomos de ${ }^{39} \mathrm{~K}$. Átomos de ${ }^{39} \mathrm{Ar}$ podem não apenas ser deslocados, mas ejetados dos grãos, perturbando o comportamento do espectro de idades e falseando valores de idades aparentes (McDougall \& Harrison, 1999). Nestes casos, a encapsulação dos grãos é uma maneira bastante efetiva de monitoramento dos efeitos de recuo, já que os átomos ejetados permanecem dentro dos invólucros, e podem ser analisados anteriormente ao processo de aquecimento por etapas (Dong et al., 1995; McDougall \& Harrison, 1999).

Para evitar problemas causados pela baixa concentração de $\mathrm{K}$ das rochas, cerca de 100 mg de grãos foram inseridos em cada uma das cápsulas para as amostras LM-DA150 e LM-DA-203 (em duplicata). Para esta última, além das alíquotas de plagioclásios frescos e sericitizados, uma mistura de grãos de anfibólio e biotita também foi encapsulada. O fragmento da amostra LM-BZ-5R que havia sido encaminhado para o Laboratório de Argônio foi britado e grãos de plagioclásio fresco e plagioclásio sericitizado, além de rocha total, foram selecionados pela equipe técnica para análise individual (fora de cápsulas). Por fim, a amostra LM-DA-161 teve apenas grãos de rocha total selecionados, por conta de sua textura mais fina. 
O processo de encapsulação das alíquotas das amostras LM-DA-203 e LM-DA-150 foi realizado previamente à irradiação por meio de um Clay Extraction Line. Cada uma das cápsulas de sílica foi selada por meio de um maçarico. Todo o material foi depositado em discos de cobre apropriados e enviado ao reator TRIGA da Universidade do Estado de Oregon (EUA), de combustível híbrido composto por U e Zr.

Durante a irradiação, além da reação principal ${ }^{39} \mathrm{~K}(\mathrm{n}, \mathrm{p}){ }^{39} \mathrm{Ar}$, outros isótopos de $\mathrm{Ar}$ podem ser produzidos e influenciar as medições de razões isotópicas. Alguns exemplos comuns são:

$$
\begin{gathered}
{ }^{40} \mathrm{Ca}(n, n \alpha){ }^{36} \mathrm{Ar}(5.3) \\
{ }^{40} \mathrm{Ca}(n, \alpha){ }^{37} \mathrm{Ar}(5.4) \\
{ }^{42} \mathrm{Ca}(n, \alpha){ }^{39} \mathrm{Ar}(5.5) \\
{ }^{40} \mathrm{~K}(n, p){ }^{40} \mathrm{Ar}(5.6)
\end{gathered}
$$

Onde $\alpha$ é a partícula alfa $\left(H e^{2+}\right)$.

Correções dos efeitos de irradiação são importantes para obter valores de idade precisos e geralmente são realizadas com o uso de padrões. Detalhes podem ser conferidos em McDougall \& Harrison (1999). Para as amostras deste estudo, a reação mais importante a ser monitorada é a 5.4 , já que os teores de Ca das rochas analisadas são elevados (9.22 $\leq \mathrm{CaO} \leq 13.53$ wt.\%). $\mathrm{O}$ isótopo ${ }^{37} \mathrm{Ar}$ resultante é radioativo (meia-vida de cerca de 35 dias), e aumenta significativamente o ruído de fundo dentro do espectrômetro, o que pode prejudicar a qualidade das análises.

\subsubsection{Análise por aquecimento em etapas e Espectrometria de Massa}

Toda a análise em espectrômetro de massa e posterior processamento dos dados foram realizados pela aluna durante o estágio realizado na Universidade de Queensland. Este trabalho foi efetuado em duas etapas principais: a primeira destinou-se às medições do gás contido no interior das cápsulas das amostras LM-DA-203 e LM-DA150; a segunda, à análise por aquecimento em etapas (step-heating) propriamente dita do material do interior das mesmas cápsulas, e também das frações das amostras LMDA-161 e LM-BZ-5R que não foram encapsuladas.

Nas duas etapas, o gás liberado foi analisado pelo Espectrômetro de Massa MAP215-50, equipado com um multiplicador eletrônico de sinal Balzers TM 217, e com duas câmaras de purificação (cleanup) de gases ativos, uma sob temperatura ambiente (responsável pela retenção de hidrogênio) e outra sob cerca de $400^{\circ} \mathrm{C}$ (oxigênio, 
nitrogênio e outros ativos). As amostras foram constantemente monitoradas via câmera SonyTM CCD. A perfuração das cápsulas de sílica foi realizada por meio do uso de um Excimer KrF Laser (Lambdaphysik MINex), enquanto o aquecimento foi realizado por um Laser de Diodo (Coherent VERDI G10).

Algumas correções são essenciais nas análises de $\mathrm{Ar}$, e precisam ser constantemente monitoradas durante a espectrometria de massa. A primeira delas é a discriminação de massa, já descrita anteriormente. No caso das datações ${ }^{40} \mathrm{Ar} /{ }^{39} \mathrm{Ar}$, geralmente, o padrão utilizado é o Ar atmosférico (Air-Pipette), já que sua composição isotópica é considerada constante e bem conhecida (Nier, 1950). O valor adotado para a razão ${ }^{40} \mathrm{Ar} /{ }^{36} \mathrm{Ar}$ (recomendado por Steiger \& Jäger, 1977), empregado neste estudo, é de 295,5 . Outro efeito a ser considerado é o ruído de fundo (baseline), causado por átomos radioativos incorporados às paredes do espectrômetro (como o ${ }^{37} \mathrm{Ar}$ ) e vazamentos, e que precisa ser determinado em todos os ciclos de medição e subtraído de todos os picos obtidos. Além destas, existe a correção dos valores de Branco, superiores ao ruído de fundo, e que consistem nos sinais detectados pelo equipamento na ausência de amostras (Renne, 2000; McDougall \& Harrison, 1999).

Neste estudo, entre amostras, foram efetuadas sequências de Branco-Air-PipetteBranco-Branco (BABB). As duplicatas foram analisadas apenas quando necessário, procurando evitar o aumento do ruído de fundo do equipamento em função dos altos teores de Ca dos diques. Para cada etapa de temperatura, 9 medições foram realizadas para garantir boa estatística nas correções do efeito de memória, característico de espectrômetros operados estaticamente, ou seja, onde o tubo principal é isolado das bombas de vácuo, como forma de atingir maior sensibilidade (McDougall \& Harrison, 1999; Vasconcelos, 2002). Finalmente, o padrão utilizado para o cálculo do parâmetro J foi a biotita GA1550, cuja idade estabelecida é de $98,8 \pm 0,5 \mathrm{Ma}$ (Renne et al., 1998). Os dados do padrão estão disponíveis no apêndice $C$.

\subsubsection{Correções e processamento dos dados}

Todos os dados obtidos na espectrometria de massa foram manipulados por meio do software "Mass Spec" (por Alan Deino, do Centro de Geocronologia de Berkeley). As correções foram efetuadas por meio dos dados de irradiação, sensibilidade do equipamento, discriminação de massa, padrões, brancos, ruído de fundo e efeitos de memória. Outra importante correção aplicada pelo software foi a de Ar atmosférico, 
que pode estar presente nas amostras e no interior do espectrômetro como contaminante. Tal correção é aplicada com base nos picos de ${ }^{36} \mathrm{Ar}$ detectados, e sua descrição detalhada pode ser encontrada em McDougall \& Harrison (1999).

Após a confecção dos espectros de idades aparentes, os platôs foram definidos seguindo os critérios de McDougall \& Harrison (1999). As incertezas das idades, por sua vez, foram calculadas pelo software por meio de propagação de diversos fatores envolvidos na análise, como as incertezas dos valores de pico, regressões lineares aplicadas aos ciclos de medição, ruídos de fundo, valores de discriminação, dados de irradiação e parâmetro J.

\subsubsection{Análise petrográfica por microscópio óptico, MEV e EDE}

Buscando investigar melhor a composição mineral das amostras, o padrão de zoneamento dos plagioclásios e os graus de alteração das diferentes fases minerais, lâminas delgadas foram confeccionadas para análise em microscópio óptico (Nikon Eclipse E400 POL). Também foram confeccionadas lâminas adicionais para as 4 amostras datadas, sem lamínula, para análise em MEV (Hitachi Tabletop Microscope TM3030), acoplado a um sistema EDE (Bruker) durante o período de trabalho na Escola de Ciências da Terra da Universidade de Queensland, paralelamente às análises de espectrometria de massa. As características microtexturais e mineralógicas gerais de cada um dos diques foram analisadas no microscópio óptico, enquanto fases muito pequenas ou não identificadas foram investigadas no MEV. Praticamente todas as análises neste último foram realizadas por meio de feixe de elétrons de $15 \mathrm{kV}$, e as concentrações aproximadas de minerais traços, alterações em grãos de piroxênio, plagioclásio e magnetita e zoneamentos foram investigadas por meio do sinal de retro espalhamento eletrônico. 


\section{RESULTADOS E DISCUSSÕES}

\subsection{Caracterização geoquímica dos diques investigados}

A caracterização dos diques iniciou-se com a análise de elementos maiores, menores e alguns traço das 22 amostras coletadas por FRX. Em seguida, 19 das 22 amostras foram selecionadas para análise de elementos traço em ICP-MS. Os resultados e suas implicações são apresentados a seguir.

\subsubsection{Elementos maiores e menores}

Os resultados das análises de elementos maiores e menores dos diques coletados encontram-se na tabela 6.1. Os diques LM-DA-207, LM-DA-210 e LM-DA-183 (representados em azul nos diagramas das figuras 6.1, 6.2 e 6.3), apesar de apresentarem baixos valores de perda ao fogo (de $0,31 \%$ a $0,46 \%$ ), mostraram-se muito alterados por processos de cloritização na análise petrográfica, e foram excluídos das análises posteriores.

Com base em seus teores de $\mathrm{SiO}_{2}$ e álcalis $\left(\mathrm{Na}_{2} \mathrm{O}\right.$ e $\left.\mathrm{K}_{2} \mathrm{O}\right)$, as amostras são classificadas como basaltos (20) e basaltos andesíticos (2), por meio do diagrama TAS (figura 6.1; Le Bas et al., 1986), e se situam abaixo da linha de separação entre rochas

alcalinas e subalcalinas definida por Irvine \& Baragar (1971). Neste e nos próximos diagramas apresentados, as amostras foram separadas em dois grupos que apresentam características geoquímicas distintas, sendo que em verde estão representadas as rochas mais primitivas (grupo A) e em laranja as mais evoluídas (grupo B). 


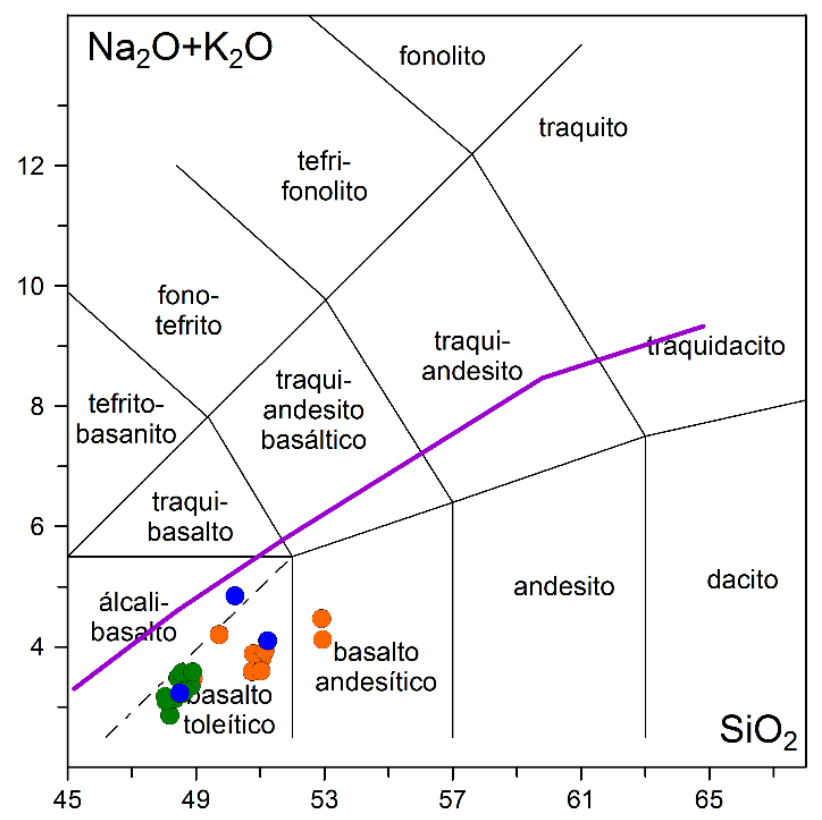

Figura 6.1: Diagrama TAS dos 22 diques coletados. As amostras do grupo A, mais primitivo, estão representadas em verde; as do grupo B, mais evoluído, em laranja. As amostras em azul foram descartadas devido a processos de alteração. A linha roxa separa os campos das rochas alcalinas e subalcalinas (Irvine \& Baragar, 1971), enquanto a preta tracejada separa os basaltos alcalinos dos toleíticos de acordo com Zanettin (1984).

De acordo com a nomenclatura proposta por De La Roche (R1-R2, figura 6.2; De La Roche et al., 1980), que leva em conta também os teores de $\mathrm{Fe}, \mathrm{Ti}, \mathrm{Al}, \mathrm{Mg}$ e Ca das rochas, verifica-se que 4 dos diques são basaltos andesíticos toleíticos, 6 são basaltos toleíticos e 12 são basaltos transicionais. É interessante destacar que todas as amostras do grupo $A$ são basaltos transicionais, enquanto as do grupo $B$ são toleíticas. A amostra LM-DA-183, proveniente de Arraial-do-Cabo, apresenta características distintas das demais nos diagramas TAS e DLR, aproximando-se mais do campo alcalino. Todos os diques apresentaram porcentagens de perda ao fogo dentro do intervalo de 0,11-1,42\%, um bom indicativo de que são foram afetados por processos significativos de alteração intempérica, capazes de prejudicar a confiabilidade dos dados. Conforme esperado, a maior parte das amostras apresenta teores de $\mathrm{TiO}_{2}$ menores que $2 \%$, sendo que 4 delas apresentam $2 \leq \mathrm{TiO}_{2} \leq 2,5 \%$ e pertencem ao grupo $\mathrm{B}$ (mais evoluído). 
Figura 6.2: Diagrama R1-R2 de nomenclatura química dos diques coletados. O padrão de cores dos símbolos obedece aos critérios da figura 5.1. A amostra LM-DA-183 está assinalada com um asterisco

$(*)$.

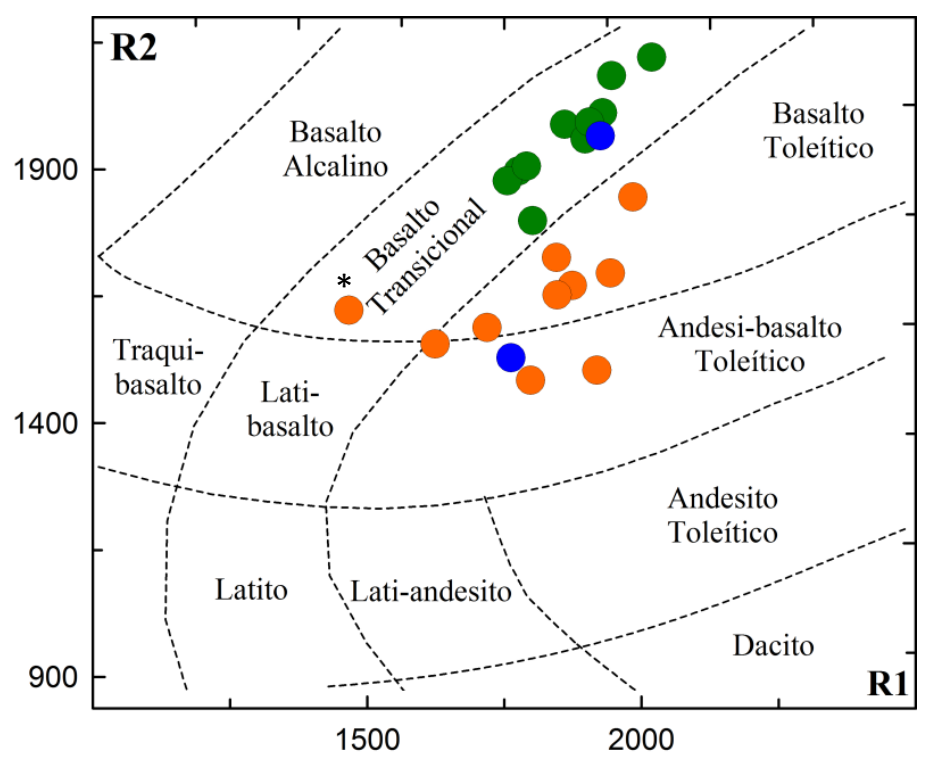

O diagrama triangular AFM também foi utilizado para investigar a qual série magmática pertencem os diques do conjunto estudado e as tendências de diferenciação magmática. As amostras encontram-se no campo das séries toleíticas de acordo com as divisões propostas por Kuno (1968) e por Irvine \& Baragar (1971), exibindo aumento dos teores de óxidos de Fe ao longo da evolução (diminuição de $\mathrm{MgO}$ ). Esse comportamento é típico dos estágios iniciais de séries toleíticas, nas quais o fracionamento significativo de magnetita não se iniciou (Wilson, 1989).

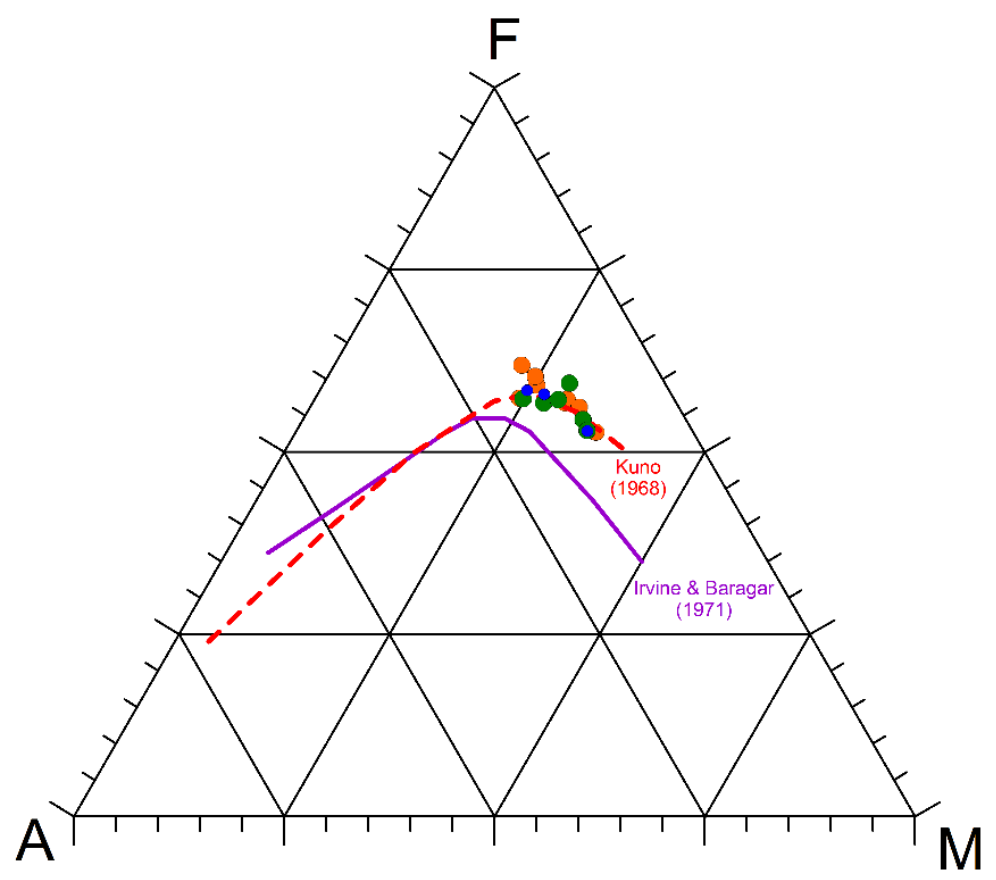

Figura 6.3: Diagrama AFM de investigação de evolução magmática, com as curvas de diferenciação e de separação das séries toleíticas e alcalinas propostas por Kuno (1968) e Irvine \& Baragar (1971). 
Tabela 6.1: Concentrações de elementos maiores e menores (\%) determinados por Fluorescência de Raios-X.

\begin{tabular}{|c|c|c|c|c|c|c|c|c|c|c|c|c|c|c|}
\hline Amostra & Localização & $\mathrm{SiO}_{2}$ & $\mathrm{TiO}_{2}$ & $\mathrm{Al}_{2} \mathrm{O}_{3}$ & $\mathrm{Fe}_{2} \mathrm{O}_{3}$ & $\mathrm{FeO}_{\mathrm{t}}$ & MnO & MgO & $\mathrm{CaO}$ & $\mathrm{Na}_{2} \mathrm{O}$ & $\mathrm{K}_{2} \mathrm{O}$ & $\mathrm{P}_{2} \mathrm{O}_{5}$ & LOI & Soma \\
\hline LM-BZ 6R & Búzios & 51,99 & 2,23 & 13,17 & 13,59 & 12,23 & 0,20 & 5,17 & 9,06 & 2,95 & 0,96 & 0,30 & 0,51 & 100,12 \\
\hline LM-BZ 15 & Búzios & 49,19 & 2,13 & 13,22 & 16,45 & 14,81 & 0,23 & 6,04 & 9,32 & 2,73 & 0,94 & 0,32 & 0,42 & 101,00 \\
\hline LM-DA 211 & Arraial & 51,70 & 2,21 & 13,04 & 13,62 & 12,26 & 0,19 & 5,17 & 9,28 & 2,49 & 1,04 & 0,29 & 0,66 & 99,69 \\
\hline LM-DA 155 & Arraial & 50,19 & 1,66 & 14,63 & 13,38 & 12,04 & 0,18 & 5,83 & 10,75 & 2,79 & 0,56 & 0,19 & 0,33 & 100,50 \\
\hline LM-DA 212 & Arraial & 50,02 & 1,71 & 13,89 & 13,88 & 12,49 & 0,19 & 5,81 & 10,38 & 2,53 & 0,73 & 0,21 & 0,45 & 99,80 \\
\hline LM-DA 200 & Búzios & 50,94 & 1,92 & 13,80 & 14,62 & 13,16 & 0,20 & 5,65 & 10,30 & 2,76 & 0,66 & 0,22 & 0,11 & 101,18 \\
\hline LM-DA 152 & Arraial & 50,04 & 1,35 & 14,79 & 12,05 & 10,84 & 0,17 & 6,82 & 11,38 & 2,48 & 0,57 & 0,16 & 0,41 & 100,23 \\
\hline LM-DA 161 & Arraial & 48,01 & 2,19 & 12,89 & 17,76 & 15,99 & 0,24 & 5,85 & 9,78 & 2,43 & 0,51 & 0,30 & 0,55 & 100,50 \\
\hline LM-DA 209 & Arraial & 50,29 & 1,80 & 13,50 & 14,07 & 12,67 & 0,20 & 6,42 & 10,40 & 2,43 & 0,63 & 0,22 & 0,48 & 100,43 \\
\hline LM-DA 203 & Cabo Frio & 47,62 & 1,12 & 14,12 & 12,90 & 11,61 & 0,19 & 8,34 & 13,37 & 2,11 & 0,23 & 0,13 & 0,56 & 100,70 \\
\hline LM-DA 208 & Búzios & 47,44 & 1,12 & 14,42 & 13,12 & 11,81 & 0,19 & 7,99 & 12,46 & 2,21 & 0,38 & 0,14 & 1,13 & 100,58 \\
\hline LM-DA 206 & Búzios & 46,91 & 1,41 & 14,17 & 13,77 & 12,39 & 0,19 & 7,06 & 12,72 & 2,26 & 0,36 & 0,17 & 1,08 & 100,10 \\
\hline LM-DA 204 & Cabo Frio & 47,46 & 1,54 & 14,30 & 13,16 & 11,85 & 0,19 & 7,24 & 12,34 & 2,26 & 0,40 & 0,18 & 0,79 & 99,86 \\
\hline LM-DA 182 & Arraial & 48,33 & 0,97 & 14,31 & 13,32 & 11,99 & 0,19 & 7,81 & 12,39 & 2,44 & 0,38 & 0,14 & 0,25 & 100,53 \\
\hline LM-DA 158 & Arraial & 47,51 & 1,88 & 12,82 & 15,72 & 14,15 & 0,21 & 6,94 & 11,25 & 2,40 & 0,30 & 0,21 & 1,14 & 100,38 \\
\hline LM-DA 205 & Búzios & 47,51 & 1,33 & 13,87 & 14,64 & 13,17 & 0,21 & 6,92 & 11,98 & 2,50 & 0,43 & 0,17 & 0,63 & 100,19 \\
\hline LM-BZ 4R & Búzios & 47,41 & 1,34 & 14,00 & 14,31 & 12,88 & 0,21 & 6,81 & 11,83 & 2,55 & 0,44 & 0,17 & 1,42 & 100,49 \\
\hline LM-BZ 5R & Búzios & 48,03 & 1,36 & 14,05 & 13,86 & 12,47 & 0,20 & 6,85 & 12,07 & 2,63 & 0,40 & 0,17 & 0,99 & 100,60 \\
\hline LM-DA 150 & Arraial & 47,45 & 1,19 & 14,75 & 12,75 & 11,48 & 0,19 & 7,79 & 13,17 & 2,18 & 0,39 & 0,15 & 0,75 & 100,76 \\
\hline LM-DA 207 & Búzios & 50,17 & 2,43 & 12,82 & 15,40 & 13,86 & 0,22 & 4,98 & 9,63 & 2,54 & 0,99 & 0,28 & 0,31 & 99,78 \\
\hline LM-DA 183 & Arraial & 49,32 & 1,50 & 13,10 & 15,16 & 13,64 & 0,22 & 5,89 & 10,03 & 3,32 & 0,95 & 0,24 & 0,46 & 100,20 \\
\hline LM-DA 210 & Arraial & 47,98 & 1,71 & 15,12 & 12,71 & 11,44 & 0,17 & 7,48 & 12,14 & 2,29 & 0,41 & 0,20 & 0,35 & 100,57 \\
\hline
\end{tabular}


O comportamento das concentrações de elementos maiores e menores das 19 amostras foi investigado utilizando o $\mathrm{MgO}$ como índice de evolução magmática (figura 6.4), uma vez que teores deste óxido diminuem com a diferenciação de suítes basálticas, em função da cristalização fracionada de olivina e piroxênio. De modo geral, a diminuição dos teores de $\mathrm{MgO}$ nas amostras é acompanhada pelo aumento de $\mathrm{SiO}_{2} \mathrm{e}$ diminuição de $\mathrm{CaO}$, o que, de fato, sugere diferenciação magmática com fracionamento de olivina e clinopiroxênio cálcico. A diminuição de MgO é também acompanhada pela diminuição dos teores de $\mathrm{Al}_{2} \mathrm{O}_{3}$, o que, juntamente com o comportamento do $\mathrm{CaO}$, sugere também fracionamento de plagioclásio. A tendência observada no comportamento do $\mathrm{P}_{2} \mathrm{O}_{5}$ não indica fracionamento de apatita, pois existe enriquecimento desse óxido, e o aumento dos teores $\mathrm{TiO}_{2}$, juntamente ao aumento nos de $\mathrm{FeO}_{\mathrm{t}}$ (principalmente no grupo mais primitivo; no grupo evoluído há dispersão), sugerem pouco ou nenhum de fracionamento de magnetita e titanomagnetita, em concordância com o resultado obtido no diagrama AFM.
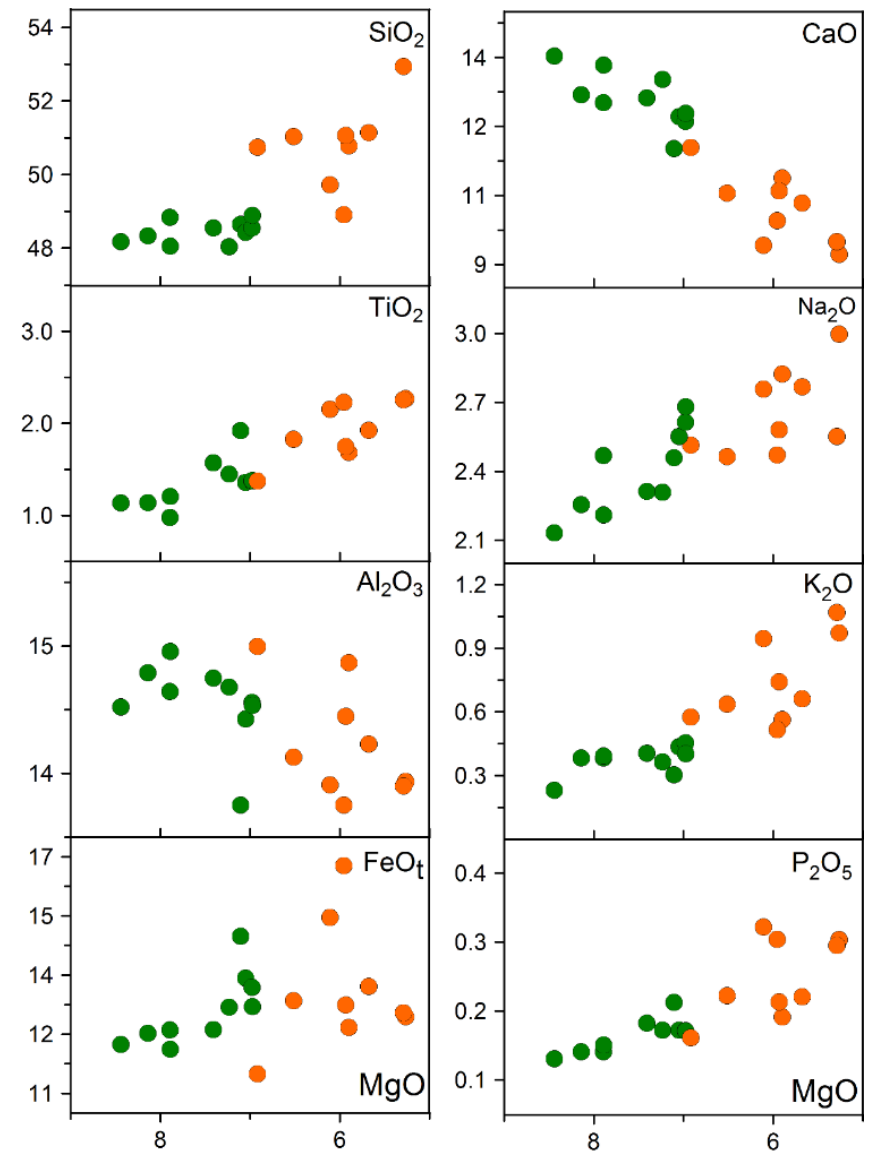

Figura 6.4: Diagramas de variação de elementos maiores (\%) em função da concentração de MgO (\%). Grupo A: verde; grupo B: laranja. 


\subsubsection{Elementos traço}

Os resultados das análises de elementos traço encontram-se na tabela 6.2. No apêndice A encontram-se as determinações dos elementos traço determinados por FRX. A existência de dois conjuntos distintos de rochas neste estudo é bem mais evidenciada no comportamento de elementos traço fortemente incompatíveis, utilizados como índices de evolução, especialmente o Th (o mais incompatível do conjunto; figura 6.5). Tal comportamento coincide com as observações de Bennio et al. (2003), segundo as quais as concentrações de elementos traço como o Zr, Sr e V permitem a identificação de dois grupos magmáticos na Região dos Lagos: um deles mais primitivo, denominado grupo A, com maiores teores de $\mathrm{MgO}(6,98-8,44 \%$ para as amostras do presente trabalho), e o outro mais evoluído, denominado grupo B, com menores teores $(5,27$ $6,92 \%)$.

Elementos traço fortemente incompatíveis apresentam $D_{i} \ll 1$ (Rollinson, 1993), e esta característica os torna bons indicadores de processos de cristalização fracionada dentro de uma mesma suíte. Em sistemas fechados, diagramas de elementos traços fortemente incompatíveis seguem tendência linear, com coeficiente linear igual ou muito próximo de zero.

Nos diagramas da figura 6.5 , o grupo A $(0,73 \leq T h \leq 1,33 \mu \mathrm{g} / \mathrm{g})$ distingue-se claramente de $B(1,55 \leq T h \leq 2,65 \mu \mathrm{g} / \mathrm{g})$, sendo que este último é também mais enriquecido em Ta, Ba, $\mathrm{U}$ e Zr (todos incompatíveis). Ao considerarmos todo o conjunto de amostras, as tendências das concentrações dos elementos fortemente incompatíveis, tais como $\mathrm{Ta}, \mathrm{U}$ e Zr, não coincidem com retas passando pela origem. Isto pode sugerir que a cristalização fracionada não ocorreu em sistema fechado, ou seja, isento de assimilação de material crustal, ou, ainda, que os grupos A e B não são cogenéticos. 
Tabela 6.2: Concentrações ( $\mu \mathrm{g} / \mathrm{g}$ ) de elementos traço obtidos por ICP-MS.

\begin{tabular}{|c|c|c|c|c|c|c|c|c|c|c|c|c|c|c|c|c|c|c|c|c|c|c|c|c|c|c|c|}
\hline Amostra & Sc & $\mathrm{Cr}$ & $\mathrm{Ni}$ & $\mathbf{R b}$ & $\mathrm{Sr}$ & Y & $\mathrm{Zr}$ & $\mathrm{Nb}$ & $\mathrm{Ba}$ & La & $\mathrm{Ce}$ & $\mathrm{Pr}$ & $\mathrm{Nd}$ & $\mathrm{Sm}$ & $\mathrm{Eu}$ & $\mathrm{Gd}$ & $\mathrm{Tb}$ & Dy & Ho & $\mathrm{Er}$ & $\mathrm{Tm}$ & $\mathrm{Yb}$ & Lu & $\mathrm{Ta}$ & $\mathrm{Pb}$ & Th & $u$ \\
\hline LM-BZ 6R & 27,9 & 44,0 & 36,7 & 21,7 & 263 & 30,4 & 158 & 12,8 & 205 & 18,0 & 40,7 & 5,21 & 22,7 & 6,09 & 1,84 & 5,75 & 0,96 & 6,03 & 1,17 & 2,97 & 0,43 & 2,60 & 0,38 & 0,79 & 2,19 & 1,83 & 0,42 \\
\hline LM-BZ 15 & 40,2 & 51,9 & 58,4 & 37,0 & 205 & 40,4 & 42 & 17,3 & 346 & 21,9 & 45,1 & 5,37 & 22,6 & 5,94 & 1,91 & 6,18 & 1,06 & 7,23 & 1,55 & 4,16 & 0,62 & 4,02 & 0,62 & 0,88 & 2,96 & 2,65 & 0,86 \\
\hline $\begin{array}{c}\text { LM-DA } \\
211 \\
\end{array}$ & 30,8 & 52,8 & 40,9 & 40,4 & 288 & 32,7 & 180 & 13,8 & 202 & 19,2 & 44,1 & 5,61 & 24,6 & 6,53 & 1,98 & 6,37 & 1,05 & 6,52 & 1,28 & 3,17 & 0,46 & 2,79 & 0,41 & 0,86 & 1,81 & 1,95 & 0,40 \\
\hline $\begin{array}{c}\text { LM-DA } \\
155 \\
\end{array}$ & 34,5 & 47,8 & 54,2 & 17,2 & 240 & 26,6 & 110 & 9,8 & 190 & 13,3 & 29,6 & 3,71 & 16,0 & 4,29 & 1,46 & 4,29 & 0,76 & 4,89 & 1,03 & 2,66 & 0,39 & 2,46 & 0,37 & 0,59 & 1,60 & 1,53 & 1,37 \\
\hline $\begin{array}{c}\text { LM-DA } \\
212 \\
\end{array}$ & 34,8 & 45,7 & 54,2 & 22,6 & 231 & 28,0 & 116 & 10,5 & 173 & 13,8 & 30,7 & 3,89 & 16,8 & 4,61 & 1,51 & 4,63 & 0,79 & 5,19 & 1,07 & 2,81 & 0,43 & 2,57 & 0,39 & 0,64 & 1,70 & 1,62 & 0,36 \\
\hline $\begin{array}{c}\text { LM-DA } \\
200 \\
\end{array}$ & 36,7 & 41,8 & 48,1 & 19,8 & 231 & 31,0 & 131 & 11,0 & 169 & 14,2 & 32,5 & 4,19 & 18,5 & 5,04 & 1,69 & 5,15 & 0,89 & 5,88 & 1,20 & 3,13 & 0,46 & 2,85 & 0,43 & 0,67 & 1,81 & 1,55 & 0,30 \\
\hline $\begin{array}{c}\text { LM-DA } \\
152 \\
\end{array}$ & 33,2 & 177,8 & 68,6 & 19,3 & 220 & 23,3 & 94 & 7,9 & 142 & 10,4 & 23,0 & 2,94 & 12,8 & 3,64 & 1,25 & 3,73 & 0,65 & 4,35 & 0,88 & 2,33 & 0,34 & 2,18 & 0,33 & 0,5 & 1,72 & 1,57 & 0,61 \\
\hline $\begin{array}{c}\text { LM-DA } \\
161 \\
\end{array}$ & 42,9 & 74,4 & 62,8 & 14,1 & 202 & 41,1 & 140 & 16,3 & 227 & 19,5 & 41,0 & 5,09 & 22,0 & 5,91 & 1,95 & 6,17 & 1,09 & 7,49 & 1,56 & 4,23 & 0,64 & 4,03 & 0,61 & 0,84 & 2,24 & 1,91 & 0,44 \\
\hline $\begin{array}{c}\text { LM-DA } \\
209 \\
\end{array}$ & 35,7 & 133,3 & 69,5 & 21,7 & 188 & 32,6 & 130 & 10,9 & 155 & 13,7 & 31,0 & 3,95 & 17,3 & 4,86 & 1,58 & 5,06 & 0,91 & 6,02 & 1,25 & 3,32 & 0,50 & 3,09 & 0,46 & 0,67 & 3,10 & 1,66 & 0,35 \\
\hline $\begin{array}{c}\text { LM-DA } \\
203 \\
\end{array}$ & 43,5 & 103,8 & 103,5 & 9,7 & 164 & 21,3 & 55 & 6,0 & 83 & 6,4 & 14,0 & 1,84 & 8,6 & 2,77 & 1,02 & 3,12 & 0,58 & 3,96 & 0,84 & 2,19 & 0,33 & 2,02 & 0,30 & 0,35 & 0,63 & 0,73 & 0,16 \\
\hline $\begin{array}{c}\text { LM-DA } \\
208 \\
\end{array}$ & 43,0 & 225,4 & 131,8 & 14,4 & 163 & 23,1 & 60 & 7,5 & 107 & 8,2 & 17,7 & 2,22 & 9,8 & 2,85 & 1,00 & 3,21 & 0,59 & 4,14 & 0,89 & 2,38 & 0,36 & 2,26 & 0,34 & 0,44 & 1,21 & 0,93 & 0,21 \\
\hline $\begin{array}{c}\text { LM-DA } \\
206 \\
\end{array}$ & 47,9 & 96,7 & 103,9 & 15,2 & 219 & 28,6 & 88 & 12,4 & 117 & 11,3 & 25,0 & 3,26 & 14,7 & 4,21 & 1,44 & 4,51 & 0,79 & 5,36 & 1,09 & 2,92 & 0,43 & 2,73 & 0,41 & 0,76 & 0,87 & 1,25 & 0,27 \\
\hline $\begin{array}{c}\text { LM-DA } \\
204 \\
\end{array}$ & 39,0 & 193,6 & 110,6 & 19,5 & 190 & 24,4 & 86 & 10,7 & 116 & 10,5 & 23,4 & 3,01 & 13,5 & 3,90 & 1,29 & 4,01 & 0,70 & 4,60 & 0,95 & 2,54 & 0,37 & 2,29 & 0,35 & 0,72 & 0,90 & 1,28 & 0,25 \\
\hline $\begin{array}{c}\text { LM-DA } \\
182 \\
\end{array}$ & 43,7 & 104,4 & 81,6 & 12,0 & 167 & 25,1 & 47 & 9,3 & 124 & 9,6 & 19,0 & 2,24 & 9,4 & 2,67 & 0,96 & 3,05 & 0,59 & 4,28 & 0,92 & 2,58 & 0,41 & 2,56 & 0,39 & 0,49 & 3,14 & 1,18 & 0,27 \\
\hline $\begin{array}{c}\text { LM-DA } \\
158 \\
\end{array}$ & 42,2 & 67,1 & 81,7 & 18,0 & 193 & 32,8 & 101 & 11,2 & 79 & 11,3 & 25,3 & 3,34 & 15,5 & 4,72 & 1,62 & 5,13 & 0,93 & 6,27 & 1,27 & 3,33 & 0,50 & 3,06 & 0,46 & 0,66 & 1,06 & 1,33 & 0,29 \\
\hline $\begin{array}{c}\text { LM-DA } \\
205 \\
\end{array}$ & 40,8 & 49,2 & 83,3 & 14,8 & 166 & 28,0 & 78 & 10,9 & 125 & 11,1 & 23,4 & 2,88 & 12,6 & 3,49 & 1,22 & 3,91 & 0,71 & 4,96 & 1,07 & 2,90 & 0,45 & 2,78 & 0,43 & 0,62 & 0,96 & 1,29 & 0,28 \\
\hline LM-BZ 4R & 39,5 & 41,1 & 77,6 & 17,4 & 170 & 28,2 & 78 & 10,9 & 159 & 11,1 & 23,7 & 2,94 & 12,6 & 3,53 & 1,23 & 3,98 & 0,72 & 5,09 & 1,09 & 2,94 & 0,45 & 2,84 & 0,43 & 0,63 & 1,05 & 1,32 & 0,28 \\
\hline LM-BZ 5R & 41,2 & 40,3 & 77,3 & 13,9 & 167 & 28,5 & 79 & 11,2 & 122 & 11,2 & 23,8 & 2,98 & 13,0 & 3,56 & 1,25 & 3,91 & 0,72 & 5,09 & 1,08 & 2,93 & 0,45 & 2,80 & 0,43 & 0,63 & 1,04 & 1,26 & 0,36 \\
\hline $\begin{array}{c}\text { LM-DA } \\
150 \\
\end{array}$ & 40,6 & 101,5 & 99,9 & 17,6 & 181 & 20,7 & 63 & 9,6 & 105 & 6 & 18,5 & 2,33 & 10,7 & 2,99 & 1,06 & 3,16 & 0,57 & 3,85 & 0,81 & 2,14 & 0,32 & 2,00 & 0,31 & 0,58 & 1,25 & 1,01 & 0,23 \\
\hline $\begin{array}{c}\text { LM-DA } \\
183 \\
\end{array}$ & 43,2 & 28,9 & 53,2 & 44,4 & 182 & 67,2 & 130 & 14,1 & 255 & 56,6 & 104,1 & 11,27 & 43,7 & 9,43 & 2,64 & 10,01 & 1,62 & 10,83 & 2,30 & 6,22 & 0,91 & 5,65 & 0,82 & 0,67 & 5,87 & 2,28 & 0,60 \\
\hline
\end{tabular}



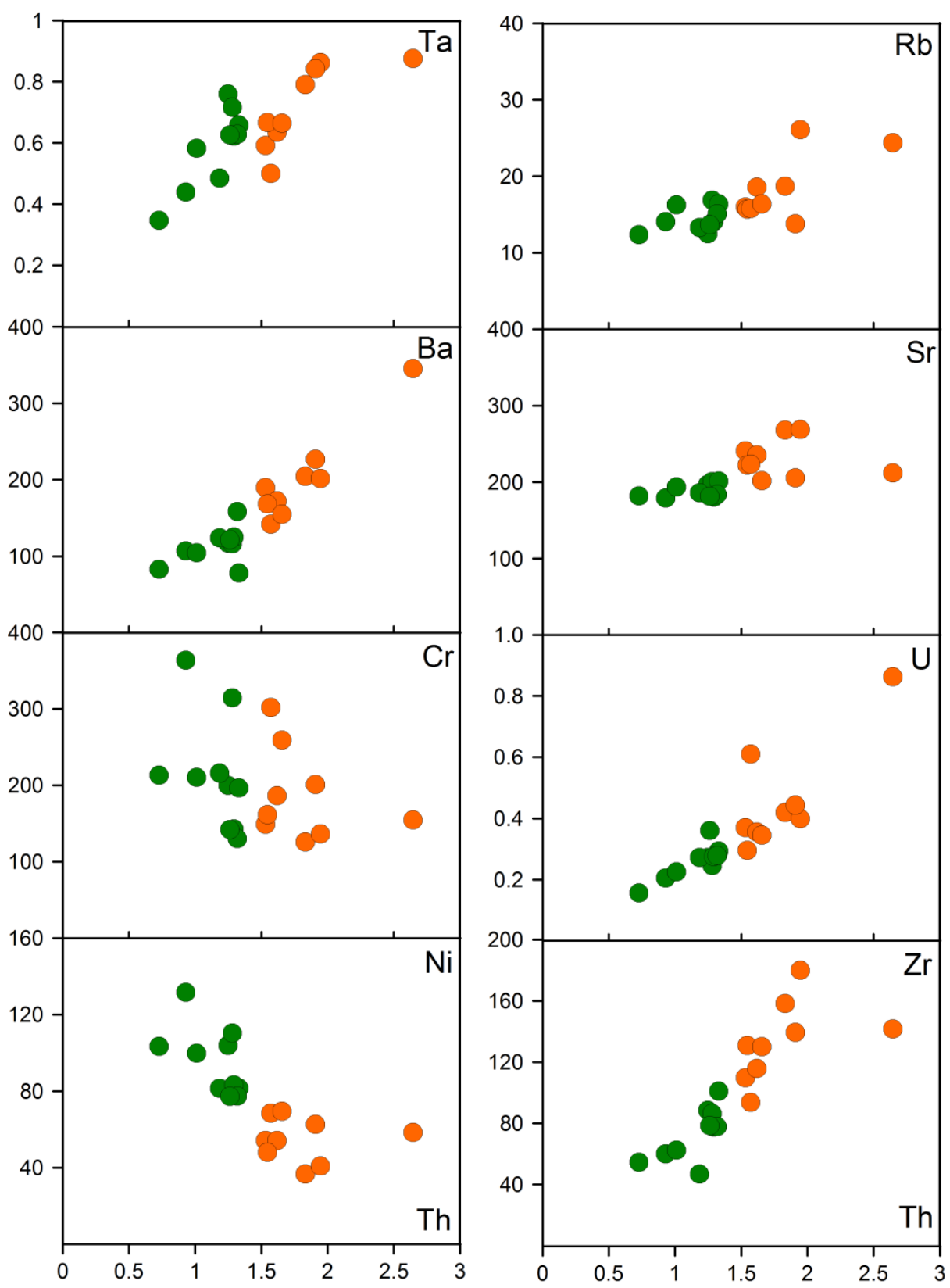

Figura 6.5: Diagramas de elementos traço compatíveis e incompatíveis em função dos teores de Th. Grupo A: verde; grupo B: laranja.

Os grupos A e B também apresentam diferenças no padrão de abundância dos elementos terras raras (ETR), normalizados pelo condrito Cl (McDonough \& Sun, 1995), conforme mostrado na figura 6.6, juntamente aos dados disponíveis em Bennio et al. (2003), também discriminados nos mesmos dois grupos magmáticos. Em ambos os grupos se nota o fracionamento dos leves, mais incompatíveis, em relação aos pesados, 
o que está de acordo com o comportamento esperado para os estágios iniciais de evolução de magmas toleíticos envolvendo a cristalização fracionada de olivina e piroxênios (Rollinson, 1993), o que é também observado nos padrões de abundância e nos gráficos das razões $\mathrm{La} / \mathrm{Sm} \mathrm{Cl}$ vs. La e Tb/Lucı vs. Tb (figura 6.7). O aumento de fracionamento entre ETR leves e pesados pode ser observado dentro de cada um dos dois grupos, por meio do diagrama de razões La/LuCI vs. La (figura 6.7). As rochas do grupo A são mais empobrecidas em ETR leves e intermediários $\left(2,18 \leq \mathrm{La} / \mathrm{Lu}_{\mathrm{CI}} \leq 3,09\right)$ do que as do grupo $B\left(3,07 \leq \mathrm{La} / \mathrm{Lu}_{\mathrm{Cl}} \leq 4,89\right)$. É interessante notar que quatro amostras do conjunto mais evoluído (LM-DA-161, LM-DA-211, LM-BZ-6R e LM-BZ-15) se destacam das demais por apresentarem um enriquecimento significativo em ETR leves e intermediárias, sendo que todas elas apresentam teores de $\mathrm{TiO}_{2}$ superiores a $2 \%$ $\left(2,13 \leq \mathrm{TiO}_{2} \leq 2,23\right)$, os quais são pouco comuns nos diques do Enxame da Serra do Mar.

O elemento Eu contrasta do restante dos ETR por ser compatível durante a cristalização fracionada de feldspato potássico e plagioclásio (Rollinson, 1993; Wilson, 1989). Leves anomalias negativas de Eu, presentes no grupo B e ausentes no grupo $A$ $\left(0,94 \leq \mathrm{Eu} / \mathrm{Eu}^{*} \leq 1,03\right)$, sugerem pouco fracionamento de plagioclásio no processo de evolução magmática, conforme também evidenciado pelas concentrações $\mathrm{Al}_{2} \mathrm{O}_{3}$, as quais são aproximadamente constantes para as rochas do grupo $A$ e com leve diminuição no grupo B (figura 6.4). 

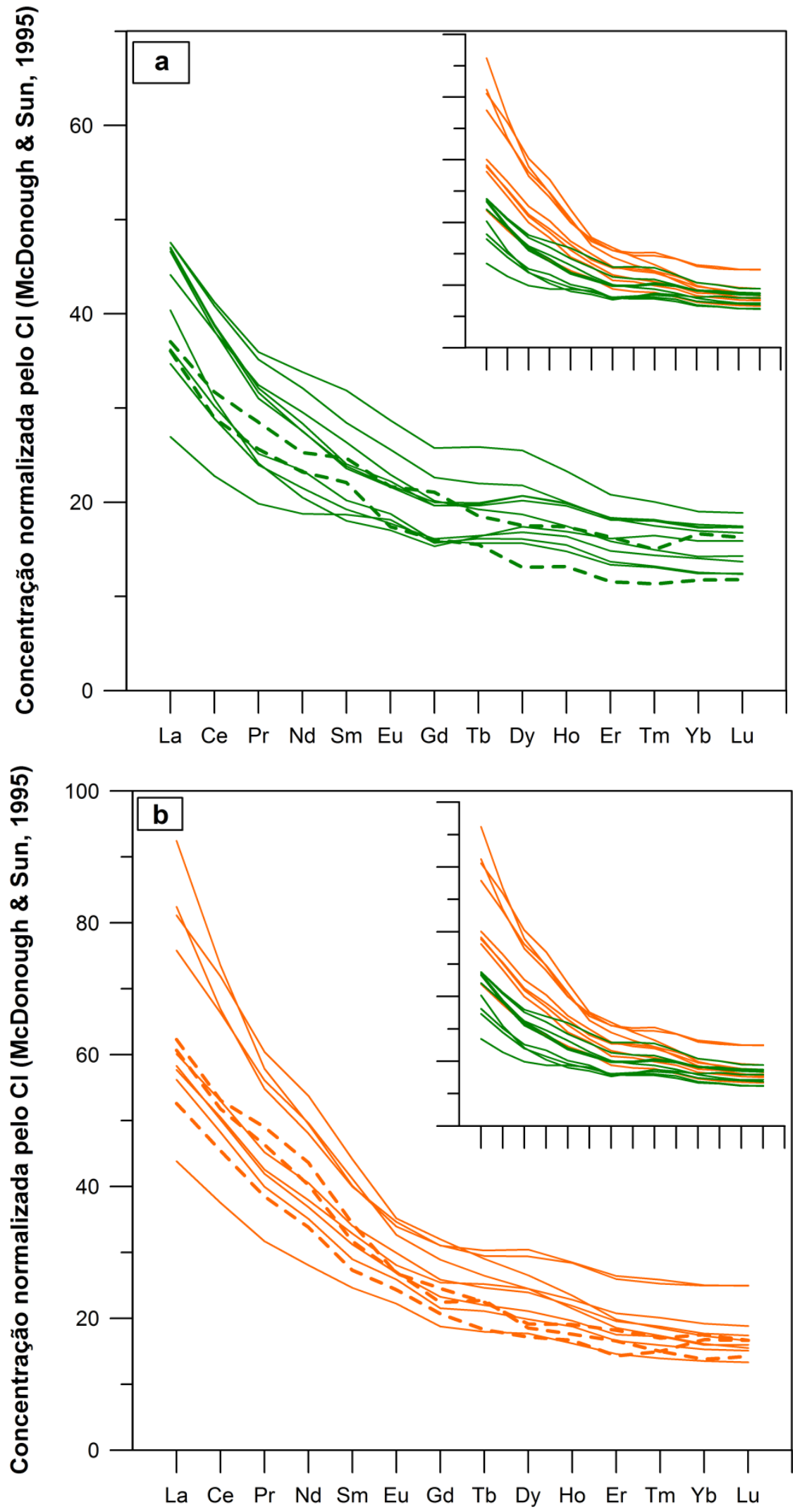

Figura 6.6: Padrões de abundância dos elementos terras raras do grupo A (a) e B (b), juntamente aos dados de Bennio et al. (2003; linhas tracejadas). No canto superior direito, padrão de abundância para as rochas dos dois grupos. 

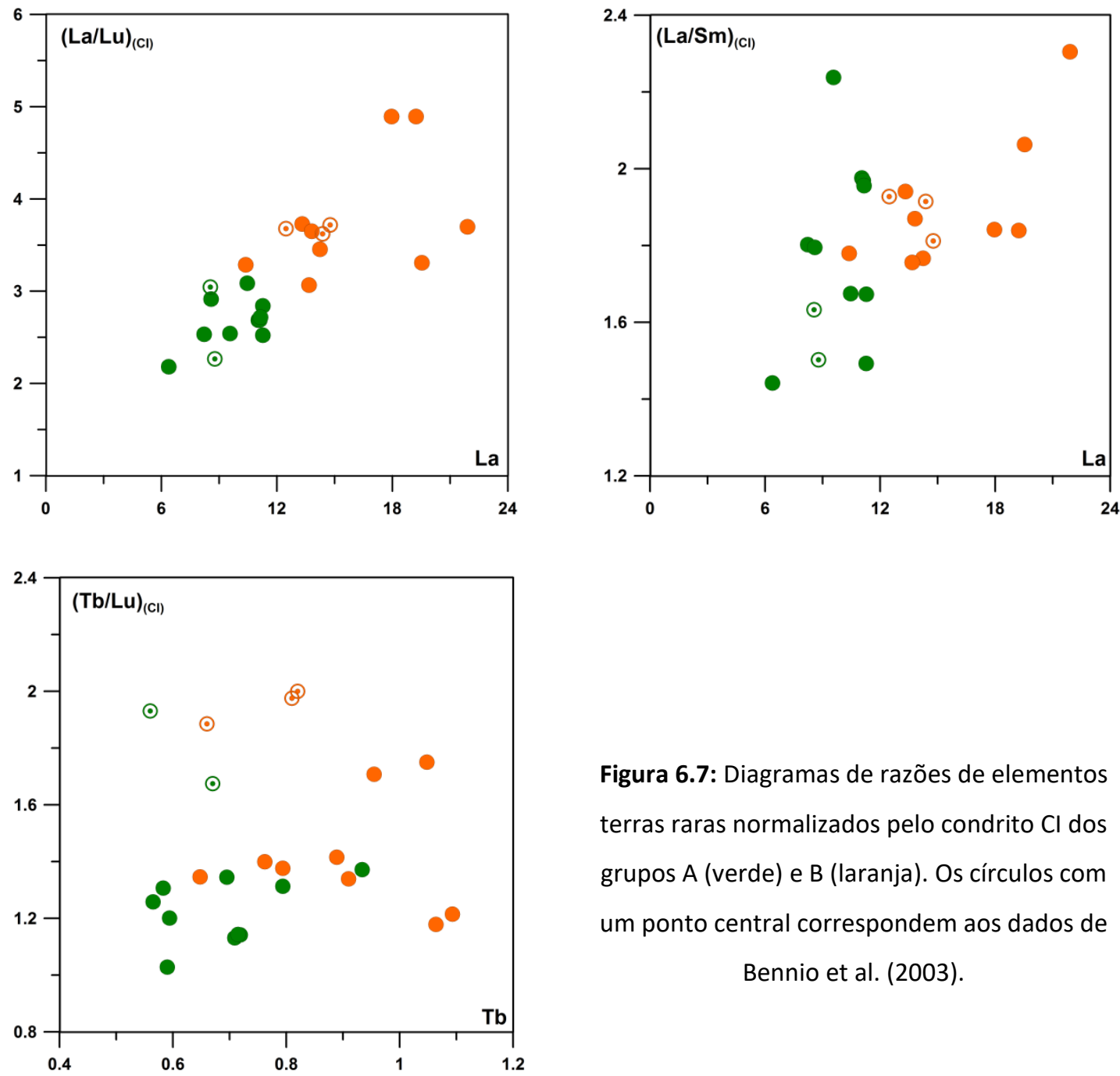

Figura 6.7: Diagramas de razões de elementos terras raras normalizados pelo condrito $\mathrm{Cl}$ dos grupos A (verde) e B (laranja). Os círculos com um ponto central correspondem aos dados de Bennio et al. (2003).

Nos diagramas multielementares de elementos incompatíveis (figura 6.8), embora o comportamento das amostras continue, no geral, condizente com os dados de Bennio et al. (2003) para os dois grupos magmáticos, observam-se algumas diferenças significativas. No grupo A, destacam-se os menores teores de $\mathrm{Pb}$ e a ausência de anomalias positivas de $\mathrm{P}$, reforçando que não houve fracionamento significativo de apatita no processo de diferenciação, contrariamente ao que ocorre com os dados de Bennio et al. (2003). As menores concentrações de $\mathrm{Pb}$ podem estar relacionadas ao cuidadoso processo de preparação das amostras para evitar a contaminação desse elemento, que é muito baixa nessas rochas, embora uma das amostras analisadas ainda tenha concentração muito similar à de Bennio et al. (2003). 
Outro aspecto importante evidenciado no diagrama da figura 6.8 é a diferença nas concentrações de $\mathrm{Nb}$, as quais são menores no estudo de Bennio et al. (2003), e que podem estar relacionadas a diferenças de exatidão entre os métodos de FRX (utilizado em Bennio et al., 2003) e ICP-MS (presente estudo). Por exemplo, para quatro dos diques amostrados (LM-DA-182, LM-BZ-5R, LM-DA-161 e LM-BZ-15), os resultados de concentração de $\mathrm{Nb}$ obtidos por FRX diferem em mais de $20 \%$ dos valores obtidos em ICP-MS (tabela 1 do apêndice A).

Os grandes picos de $U$ presentes em três das amostras do grupo B (LM-BZ-15, LMDA-152 e LM-DA-155) diferem totalmente do comportamento das demais rochas e suas possíveis causas estão sendo investigadas. A amostra LM-BZ-15 também se destaca em função de altas concentrações de Th, Rb e Ba. Além disso, sua concentração de $\mathrm{Pb}$

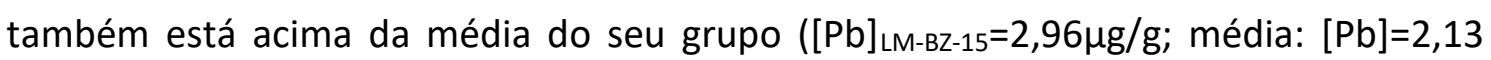
$\mu \mathrm{g} / \mathrm{g})$, apesar de seu teor de $\mathrm{MgO}$ ser apenas um pouco mais elevado em relação à média

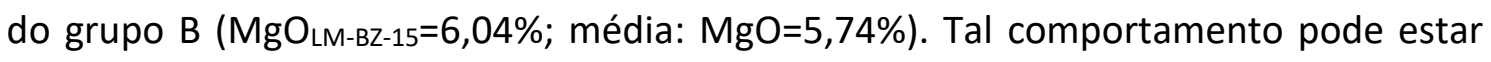
associado com o grande contato deste dique com a água do mar, e à consequente formação de minerais secundários por processos de alteração que podem modificar a concentração de $\mathrm{Pb}$ (Nobre Silva et al., 2009). Cabe também destacar que essas três amostras não possuem composições isotópicas de $\mathrm{Pb}$ muito mais radiogênicas dos que as demais, sugerindo que urânio foi possivelmente introduzido no sistema mais recentemente, talvez por água do mar, conforme indicado por estudos envolvendo desequilíbrio radioativo da série de decaimento do ${ }^{238} \mathrm{U}$ (Condomines et al., 1981). Entretanto, não se pode descartar que essas concentrações anômalas estejam relacionadas a problemas analíticos ou contaminações durante a pulverização das amostras; desta forma, uma nova pulverização para posterior análise por ICP-MS está sendo realizada.

Para as amostras do grupo B, observa-se também a presença de anomalias negativas de $\mathrm{Sr}$, reforçando a possibilidade de fracionamento de plagioclásio, conforme evidenciado nos diagramas de elementos maiores e pelas anomalias de Eu levemente negativas nos diagramas de ETR. 

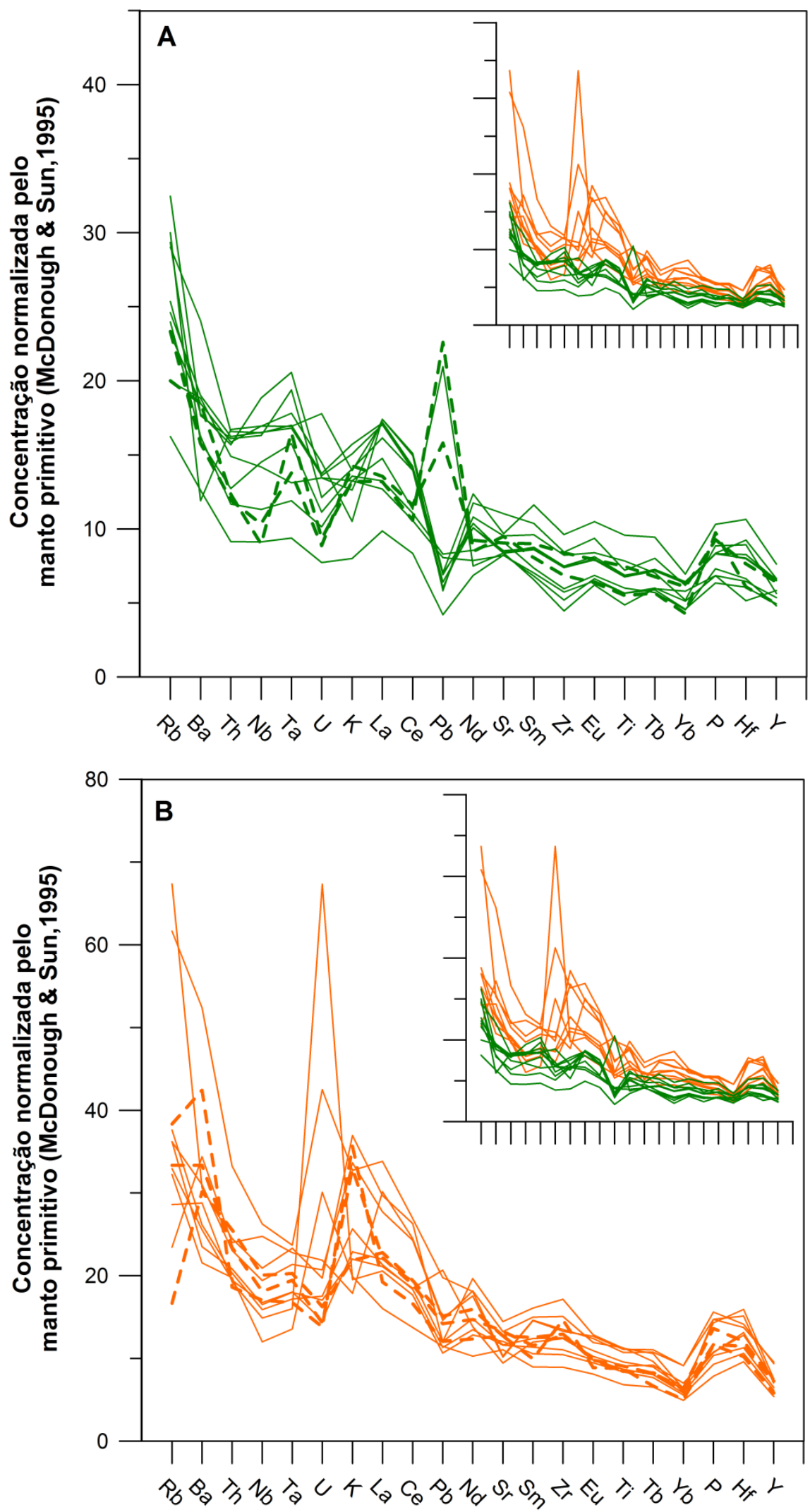

Figura 6.8: Padrões de abundância dos elementos incompatíveis do grupo $A(A)$ e $B(B)$, juntamente aos dados de Bennio et al. (2003; linha tracejada). No canto superior direito, padrão de abundância para as rochas dos dois grupos. 


\subsubsection{Comparações com diques BTi aflorantes na serra e basaltos da PMP}

Razões entre elementos fortemente incompatíveis são geralmente muito efetivas na discriminação de grupos magmáticos, podendo também fornecer importantes informações petrogenéticas. Dessa forma, diferentes razões entre esses elementos foram plotadas juntamente aos dados da literatura para os diques BTi da Região dos Lagos disponíveis em Bennio et al. (2003; discriminados em A e B) e Corval (2009; que tratou esses diques de forma indiscriminada). Os grupos A e B permanecem distinguíveis nos casos Th/Ta vs. Th e Th/Zr vs. Th (figura 6.9) e a maioria dos dados reportados por Corval (2009) é semelhante ao grupo A, com concentrações de Th inferiores a 1,6 $\mu \mathrm{g} / \mathrm{g}$. Neste tipo de diagrama, magmas gerados por diferentes graus de fusão de uma mesma fonte mantélica, que sofreram em seguida cristalização fracionada em sistema fechado, tenderiam a se comportar como retas distintas, mas subparalelas ao eixo das abscissas. Entretanto, os dados encontram-se muito dispersos para ambos os grupos, impossibilitando afirmar a existência desses processos.

Procurando investigar melhor as relações petrogenéticas entre as amostras deste estudo e outras intrusões e derrames BTi, foram efetuados diagramas de elementos traço utilizando o Th como índice de evolução. Tais diagramas incorporam tanto os dados dos diques BTi da Suíte Serrana e da Região dos Lagos (Marques, 2001; Bennio et al., 2003; Corval, 2009), como também derrames BTi da PMP do tipo Gramado (Piccirillo \& Melfi, 1988; Marques et al., 1989; Peate et al., 1992; Peate, 1997; Barreto et al., 2016) e Esmeralda (Marques, 2001; figura 6.10). Os basaltos da Bacia de Campos (Mizusaki et al., 1992), por se aproximarem muito do comportamento dos derrames Gramado, não foram incluídos nos diagramas. 

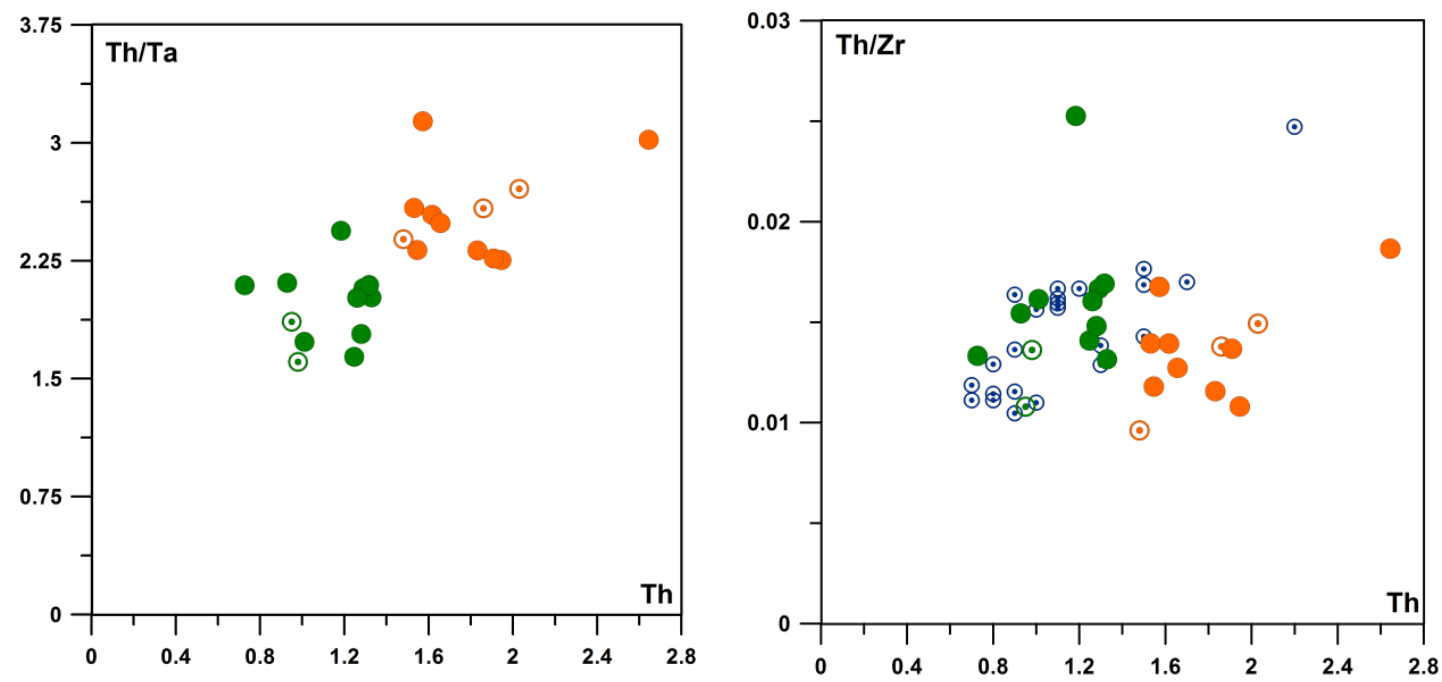

Figura 6.9: Diagramas de razões de elementos traço incompatíveis em função das concentrações de

Th. Grupo A: verde; grupo B: laranja. Os dados de A e B representados com círculos com pontos centrais correspondem às amostras de Bennio et al. (2003), enquanto os círculos vazados azuis às de Corval (2009).

As amostras do grupo A assemelham-se aos basaltos Esmeralda nos diagramas de Zr e La, os quais são marcados por concentrações relativamente mais baixas de elementos incompatíveis (e.g. Marques et al., 1989; Peate et al., 1992), enquanto o grupo B aparenta dispersar-se a partir da extremidade mais enriquecida dos mesmos derrames, afastando-se da tendência dos basaltos do tipo Gramado. As amostras da Região dos Lagos, reportadas como pertencentes a um único grupo e denominadas por Corval (2009) como "A", espalham-se entre ambos os grupos A e B do presente estudo. Além disso, tanto os diques de $A$ quanto de $B$ apresentam concentrações notadamente maiores de $\mathrm{Nb}$ e Ta (elementos de comportamento geoquímico semelhante) que todo o conjunto de derrames. Estas características diferenciam consideravelmente os diques BTi da Região dos Lagos daqueles do restante do enxame, localizados na região serrana, investigados por Marques (2001) e Corval (2009; denominado grupo "B"), cuja tendência coincide com o comportamento dos derrames do tipo Gramado da PMP.

Os diagramas de elementos fortemente incompatíveis exibem diferentes alinhamentos lineares para os grupos A e B e para os campos representativos dos derrames da PMP, o que sugere o envolvimento de fontes mantélicas distintas em sua gênese. Além disso, as tendências de alto coeficiente angular de $A$ e $B$ sugerem o envolvimento de processos de diferenciação por cristalização fracionada com pouca 
assimilação de material crustal, também detectável nas amostras de Bennio et al. (2003), e em parte do grupo de rochas analisado por Corval (2009).
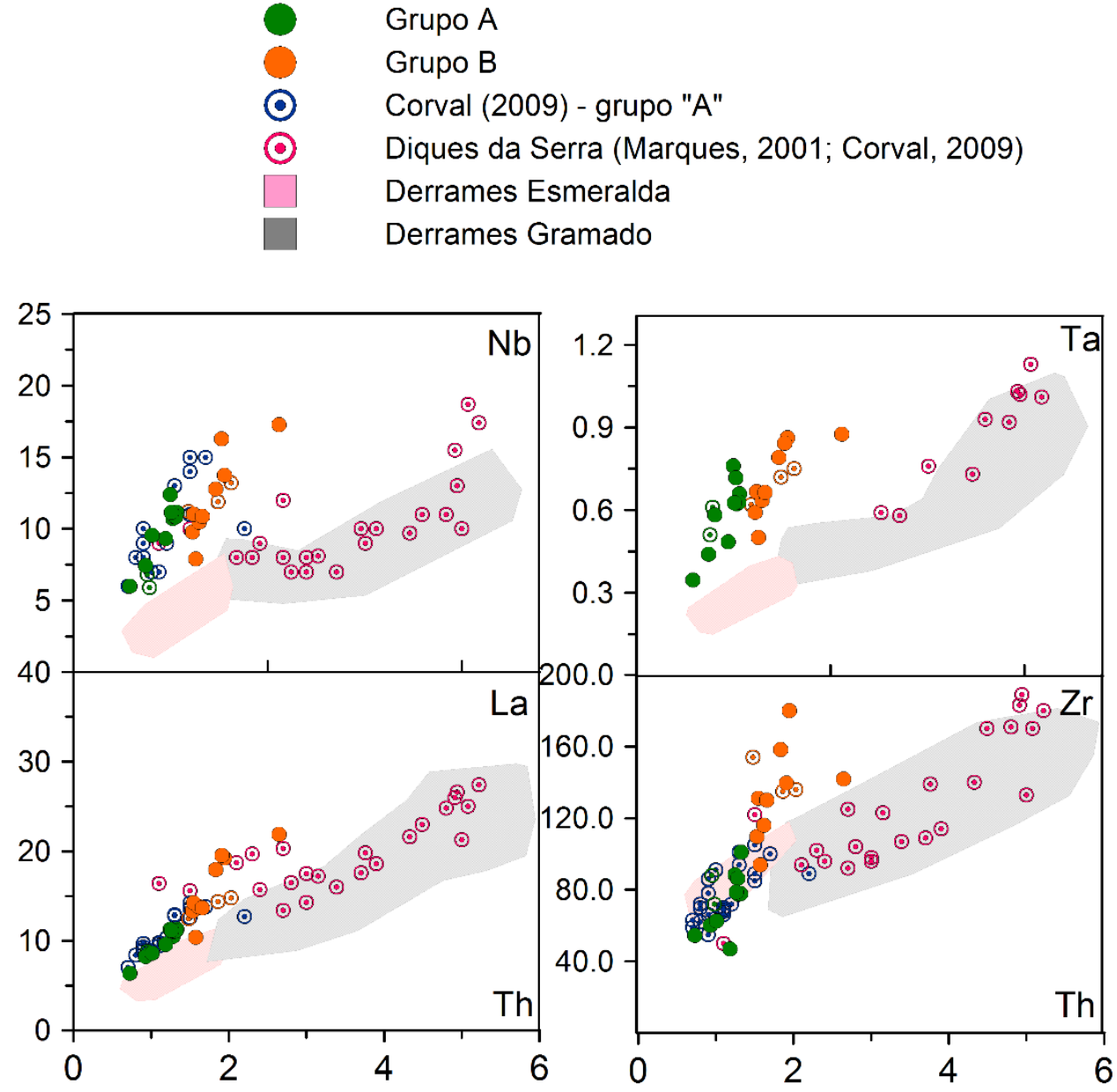

Figura 6.10: Diagramas de elementostraço compatíveis e incompatíveis dos diques estudados, juntamente aos derrames e intrusões BTi da PMP. Dados do grupo A e B representados com um círculo com um ponto central foram retirados de Bennio et al. (2003).

\subsection{Análises de isótopos de $\mathrm{Sr}, \mathrm{Nd}$ e $\mathrm{Pb}$ e aspectos petrogenéticos}

Nove amostras foram selecionadas entre os grupos A e B para determinação das razões isotópicas ${ }^{87} \mathrm{Sr} /{ }^{86} \mathrm{Sr},{ }^{143} \mathrm{Nd} /{ }^{144} \mathrm{Nd},{ }^{206} \mathrm{~Pb} /{ }^{204} \mathrm{~Pb},{ }^{207} \mathrm{~Pb} /{ }^{204} \mathrm{~Pb}$ e ${ }^{208} \mathrm{~Pb} /{ }^{204} \mathrm{~Pb}$, disponíveis na tabela 6.3. As razões iniciais foram calculadas para a idade de $132 \mathrm{Ma}$, obtida a partir de geocronologia ${ }^{40} \mathrm{Ar} /{ }^{39} \mathrm{Ar}$ em anfibólio na amostra LM-DA-203 (grupo A; seção 6.4), e foram plotadas nos gráficos das figuras 6.11, 6.12 e 6.13, juntamente aos resultados apresentados por Bennio et al. (2003). Nessas figuras, são apresentadas as razões isotópicas dos derrames Gramado e Esmeralda da PMP, e também de três dos diques de Horingbaai menos contaminados por crosta continental, situados no litoral da 
Namíbia (Thompson et al., 2001), pelo fato de apresentarem semelhanças geoquímicas com o grupo A do presente estudo. A origem dessas intrusões remonta às fases mais finais do magmatismo Paraná-Etendeka, associadas à ruptura do Gondwana durante a fase embrionária de criação de assoalho oceânico; por conta disso, suas características geoquímicas exibem participação significativa de componentes astenosféricos (tipo NMORB) em sua gênese.

Para o grupo A, os dados concentram-se nos intervalos $0,7037 \leq{ }^{87} \mathrm{Sr} /{ }^{86} \mathrm{Sr}_{132} \leq$ 0,70426; $0,51256 \leq{ }^{143} \mathrm{Nd} /{ }^{144} \mathrm{Nd}_{132} \leq 0,51264 ; 17,14477 \leq{ }^{206} \mathrm{~Pb} /{ }^{204} \mathrm{~Pb}_{132} \leq 18,16103$; $15,5140 \leq{ }^{207} \mathrm{~Pb} /{ }^{204} \mathrm{~Pb}_{132} \leq 15,56419$ e $38,11525 \leq{ }^{208} \mathrm{~Pb} /{ }^{204} \mathrm{~Pb}_{132} \leq 39,16987$; para o grupo B, $0,70557 \leq{ }^{87} \mathrm{Sr}^{86} \mathrm{Sr}_{132} \leq 0,70618,0,51223 \leq{ }^{143} \mathrm{Nd} /{ }^{144} \mathrm{Nd}_{132} \leq 0,51237 ; 17,14540 \leq$ ${ }^{206} \mathrm{~Pb} /{ }^{204} \mathrm{~Pb}_{132} \leq 17,68000 ; \quad 15,47705 \leq{ }^{207} \mathrm{~Pb} /{ }^{204} \mathrm{~Pb}_{132} \leq 15,56673$ e $38,06794 \leq$ ${ }^{208} \mathrm{~Pb} /{ }^{204} \mathrm{~Pb}_{132} \leq 38,72454$. Isso mostra que, em termos isotópicos, os grupos $\mathrm{A}$ e $\mathrm{B}$ tem assinaturas bem distintas (figuras 6.11, 6.12 e 6.13). 
Tabela 6.3: Razões isotópicas de $\mathrm{Sr}, \mathrm{Nd}$ e Pb medidas e recalculadas, juntamente às concentrações de Rb (FRX), $\mathrm{Sr}$ (FRX), Sm, Nd, U, Th e Pb (ICP-MS; em $\mu \mathrm{g} / \mathrm{g}$ ). As incertezas associadas aos valores medidos são fornecidas entre parênteses, e correspondem às últimas casas decimais.

\begin{tabular}{|c|c|c|c|c|c|c|c|c|c|c|c|c|c|c|c|c|c|}
\hline Amostra & ${ }^{87 / 86} \mathrm{Sr}_{\mathrm{m}}$ & ${ }^{87 / 86} \mathrm{Sr}_{132}$ & ${ }^{143 / 144} \mathrm{Nd}_{\mathrm{m}}$ & ${ }^{143 / 144} \mathrm{Nd}_{132}$ & ${ }^{206 / 204} \mathrm{~Pb}_{\mathrm{m}}$ & ${ }^{206 / 204} \mathrm{~Pb}_{132}$ & ${ }^{207 / 204} \mathrm{~Pb}_{\mathrm{m}}$ & $207 / 204 \mathrm{~Pb}_{132}$ & $208 / 204 \mathrm{~Pb}_{\mathrm{m}}$ & $208 / 204 \mathrm{~Pb}_{132}$ & $\mathbf{R b}$ & $\mathrm{Sr}$ & Sm & Nd & u & Th & $\mathrm{Pb}$ \\
\hline $\begin{array}{c}\text { LM-BZ } \\
6 \mathrm{R}\end{array}$ & 0,706554(19) & 0,706176 & $0,512373(7)$ & 0,512234 & $17,768(6)$ & 17,519 & $15,489(5)$ & 15,477 & $38,458(15)$ & 38,102 & 18,7 & 268,2 & 6,09 & 22,7 & 0,42 & 1,83 & 2,19 \\
\hline $\begin{array}{c}\text { LM-DA } \\
155\end{array}$ & $0,706039(20)$ & 0,705679 & $0,512427(7)$ & 0,512288 & $17,671(9)$ & 17,370 & $15,494(9)$ & 15,479 & $38,536(25)$ & 38,129 & 16,0 & 241,0 & 4,29 & 16,0 & 0,37 & 1,53 & 1,60 \\
\hline $\begin{array}{c}\text { LM-DA } \\
152 \\
\end{array}$ & $0,706301(22)$ & 0,705918 & $0,512454(7)$ & 0,512307 & $17,822(5)$ & 17,360 & $15,508(5)$ & 15,486 & $38,456(13)$ & 38,068 & 15,8 & 223,7 & 3,64 & 12,8 & 0,61 & 1,57 & 1,72 \\
\hline $\begin{array}{c}\text { LM-DA } \\
161 \\
\end{array}$ & $0,705929(18)$ & 0,705565 & $0,512508(7)$ & 0,512368 & $17,939(6)$ & 17,680 & $15,579(6)$ & 15,567 & $38,604(15)$ & 38,240 & 13,8 & 205,7 & 5,91 & 22,0 & 0,44 & 1,91 & 2,24 \\
\hline $\begin{array}{c}\text { LM-DA } \\
209\end{array}$ & $0,70625(18)$ & 0,705810 & $0,512517(7)$ & 0,512371 & $17,29(6)$ & 17,145 & $15,503(5)$ & 15,496 & $38,952(15)$ & 38,725 & 16,4 & 202,2 & 4,86 & 17,3 & 0,35 & 1,66 & 3,10 \\
\hline $\begin{array}{c}\text { LM-DA } \\
203 \\
\end{array}$ & $0,704382(17)$ & 0,704012 & $0,512809(8)$ & 0,512642 & $18,225(11)$ & 17,899 & $15,538(12)$ & 15,522 & $38,610(36)$ & 38,115 & 12,4 & 182,0 & 2,77 & 8,6 & 0,16 & 0,73 & 0,63 \\
\hline $\begin{array}{c}\text { LM-DA } \\
206 \\
\end{array}$ & $0,704117(17)$ & 0,703773 & $0,512783(8)$ & 0,512634 & $18,575(11)$ & 18,161 & $15,584(11)$ & 15,564 & $38,893(32)$ & 38,275 & 12,5 & 197,0 & 4,21 & 14,7 & 0,27 & 1,25 & 0,87 \\
\hline $\begin{array}{c}\text { LM-BZ } \\
5 \mathrm{R}\end{array}$ & $0,704699(16)$ & 0,704291 & $0,512699(8)$ & 0,512557 & $18,233(7)$ & 17,773 & $15,562(7)$ & 15,540 & $39,063(18)$ & 38,537 & 13,7 & 181,8 & 3,56 & 13,0 & 0,36 & 1,26 & 1,04 \\
\hline $\begin{array}{c}\text { LM-DA } \\
150\end{array}$ & $0,704718(18)$ & 0,704262 & $0,512766(7)$ & 0,512621 & $17,383(5)$ & 17,145 & $15,523(4)$ & 15,511 & $39,518(13)$ & 39,170 & 16,3 & 193,9 & 2,99 & 10,7 & 0,23 & 1,01 & 1,25 \\
\hline
\end{tabular}




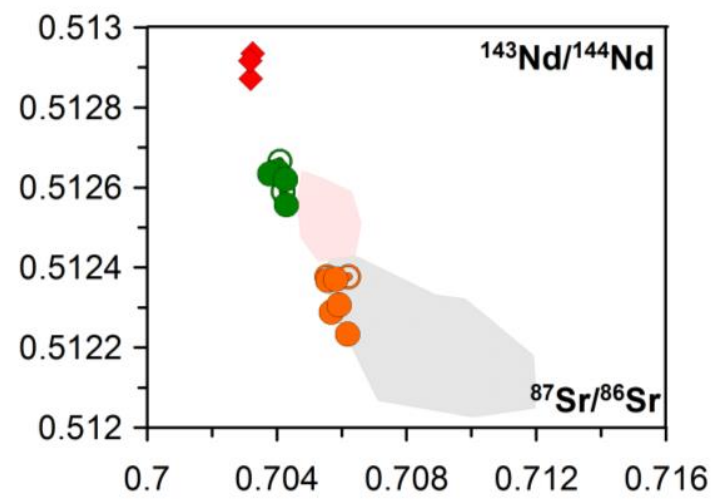

\section{Legenda}

Derrames Esmeralda

Derrames Gramado

Grupo B

Grupo A

Diques Horingbaai (Thompson et al., 2001)

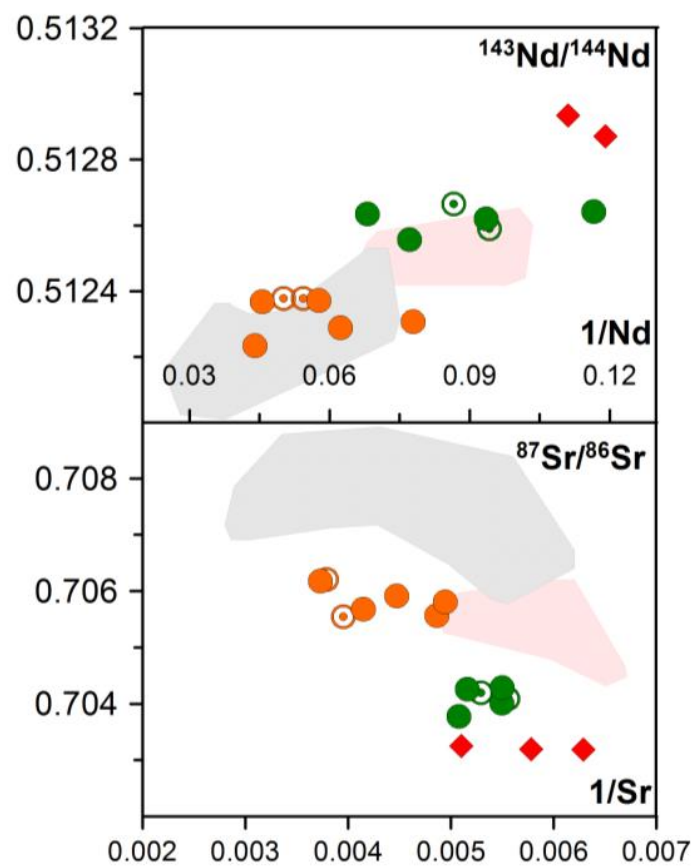

Figura 6.11: Diagramas de razões isotópicas iniciais de Sr e Nd dos grupos A e B, juntamente aos derrames BTi da PMP e diques primitivos da Namíbia. Os círculos com um ponto central representam os dados de Bennio et al. (2003).
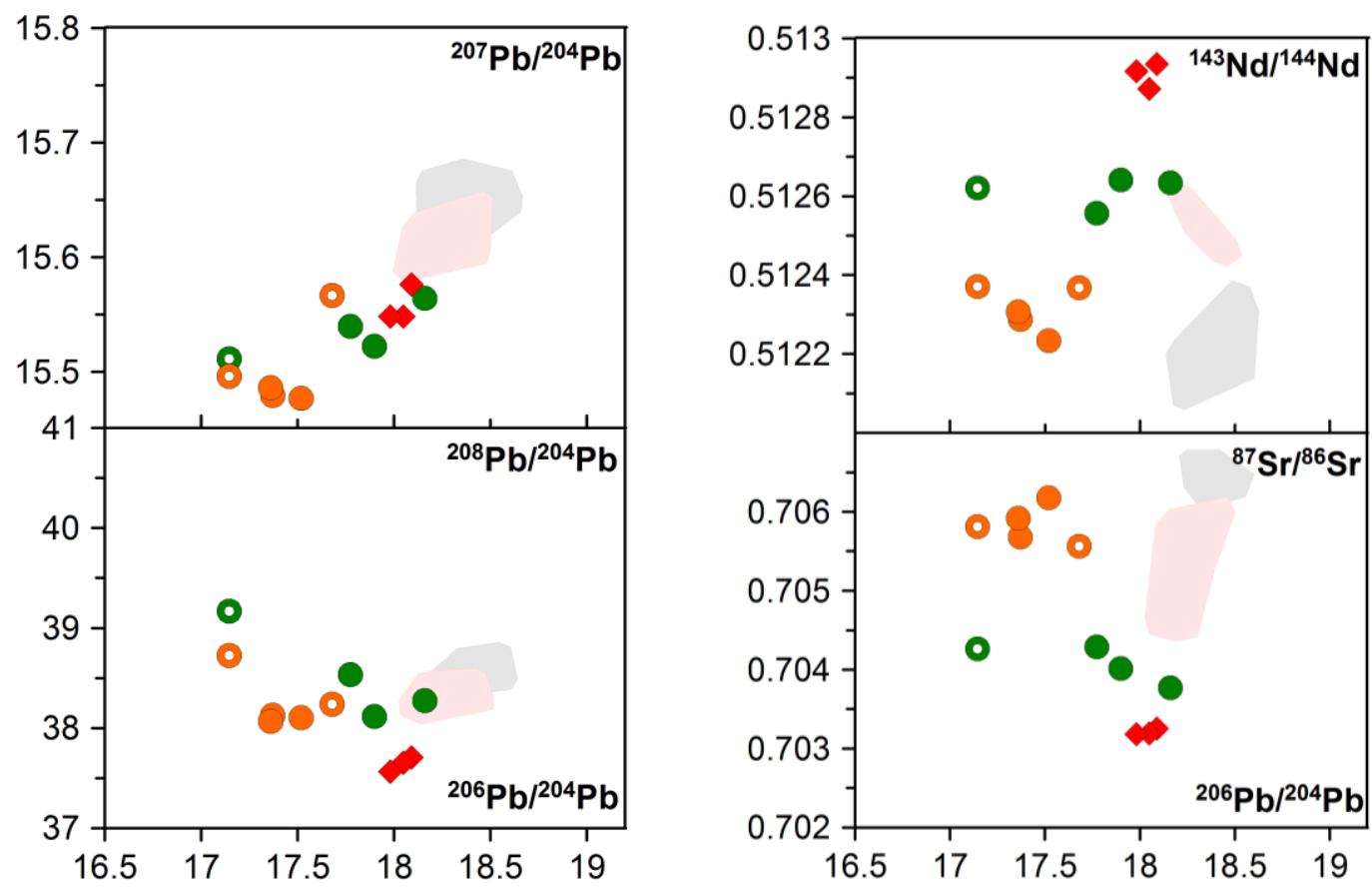

Figura 6.12: Diagramas de razões isotópicas iniciais de $\mathrm{Sr}, \mathrm{Nd}$ e $\mathrm{Pb}$ dos grupos $\mathrm{A}$ e $\mathrm{B}$, juntamente aos derrames BTi da PMP e diques primitivos da Namíbia. Os dados representados com um círculo vazado apresentam comportamento anômalo nas razões isotópicas de Pb. 

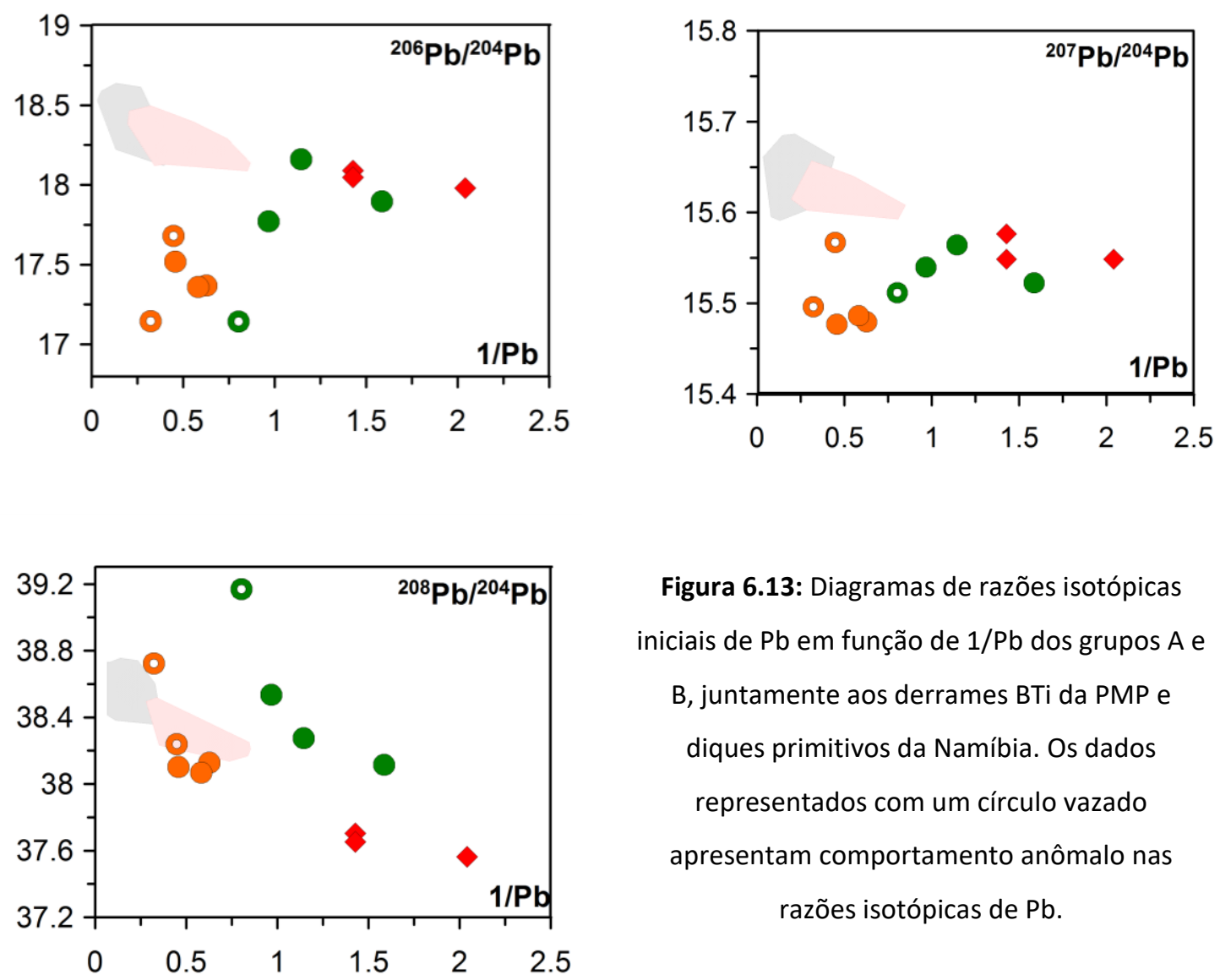

Figura 6.13: Diagramas de razões isotópicas iniciais de $\mathrm{Pb}$ em função de $1 / \mathrm{Pb}$ dos grupos $\mathrm{A}$ e

B, juntamente aos derrames BTi da PMP e diques primitivos da Namíbia. Os dados representados com um círculo vazado apresentam comportamento anômalo nas razões isotópicas de $\mathrm{Pb}$.

No diagrama de ${ }^{143} \mathrm{Nd} /{ }^{144} \mathrm{Nd}_{132}$ vs. ${ }^{87} \mathrm{Sr} /{ }^{86} \mathrm{Sr}_{132}$, o grupo A se aproxima do campo dos derrames Esmeralda, enquanto o grupo B é distinto tanto destes, quanto dos derrames Gramado (figura 6.11). As diferenças entre os diques investigados e os derrames se acentuam no comportamento das composições isotópicas de $\mathrm{Pb}$, já que as intrusivas apresentam menores razões ${ }^{206} \mathrm{~Pb} /{ }^{204} \mathrm{~Pb}_{132} \mathrm{e}^{207} \mathrm{~Pb} /{ }^{204} \mathrm{~Pb}_{132}$. Vale destacar que as razões isotópicas de $\mathrm{Pb}$ de três amostras (LM-DA-150, LM-DA-209 e LM-DA-161, representadas por círculos vazados) não foram consideradas por se apresentarem muito distintas das demais, provavelmente em decorrência da presença de sulfetos, conforme observado nas análises realizadas em microscópio eletrônico de varredura (apresentadas na seção 6.3).

O comportamento dos isótopos de $\mathrm{Sr}$ e $\mathrm{Pb}$ se opõe ao esperado para processos de assimilação de material crustal (mistura simples), ou ainda para cristalização fracionada com assimilação concomitante (AFC), já que a crosta continental é mais radiogênica em 
Sr e Pb (Rollinson, 1993; Wilson, 2005). Mesmo assim, alguns testes de modelos de processos AFC foram efetuados para investigar a possibilidade de um processo de evolução por cristalização fracionada com contaminação crustal, conforme proposto por Bennio et al. (2003), para explicar a cogeneticidade dos grupos A e B.

Para testar tal hipótese, uma série de curvas de evolução magmática do tipo AFC foram calculadas com base nas equações definidas por De Paolo (1981), utilizando como end-members a média dos diques de Horingbaai, e várias componentes da crosta continental, dentre elas estimativas de crosta continental global e crosta continental inferior (Huang et al., 1995; Rudnick \& Gao, 2003) e ortognaisses da região de Cabo Frio (Fonseca, 1993). Uma vez que não há dados de isótopos de $\mathrm{Pb}$ para rochas ígneas da região, resultados dos granitos neoproterozoicos da suíte Paulo Lopes, do sul do estado de SC (Florisbal, 2011), foram utilizados nos testes. Os coeficientes de partição foram selecionados na plataforma GERM, e provêm de diversos trabalhos (Dostal et al., 1983; McKay \& Weill, 1977; Fujimaki et al., 1984; Dunn \& Sem, 1994). As estimativas da percentagem de cada mineral fracionado utilizadas para o cálculo do $D_{\text {global, }}$ por sua vez, basearam-se nas porcentagens de fenocristais da assembleia fracionante, e consistiram em 53\% de plagioclásio, $40 \%$ de piroxênio e 7\% de olivina (Bennio et al., 2003; Corval, 2009; presente estudo baseado na proporção de fenocristais presentes na matriz). A razão entre as taxas de cristalização e assimilação utilizada foi de 0,15.

Nenhum dos casos testados ajustou-se satisfatoriamente a todos os sistemas isotópicos no sentido de definir um caminho evolutivo entre os grupos A e B; tampouco os dados do grupo A, isoladamente, adequaram-se às curvas obtidas. Os modelos que incorporam os valores dos diques Horingbaai como end-member e os dados de Fonseca (1993; para Sr e Nd) e Florisbal (2011; para Pb) forneceram os melhores ajustes (figura 6.14). O modelo ajusta-se bem ao comportamento dos dados para os sistemas isotópicos de $\mathrm{Nd}$ e $\mathrm{Sr}$, considerando-se também os dados da literatura. Para o caso do $\mathrm{Pb}$, no entanto, a escolha das médias de Horingbaai mostrou-se inadequada, uma vez que as amostras dos grupos A e B são ainda menos radiogênicas para as razões ${ }^{206} \mathrm{~Pb} /{ }^{204} \mathrm{~Pb}_{132}$ e ${ }^{207} \mathrm{~Pb} /{ }^{204} \mathrm{~Pb}_{132}$. 

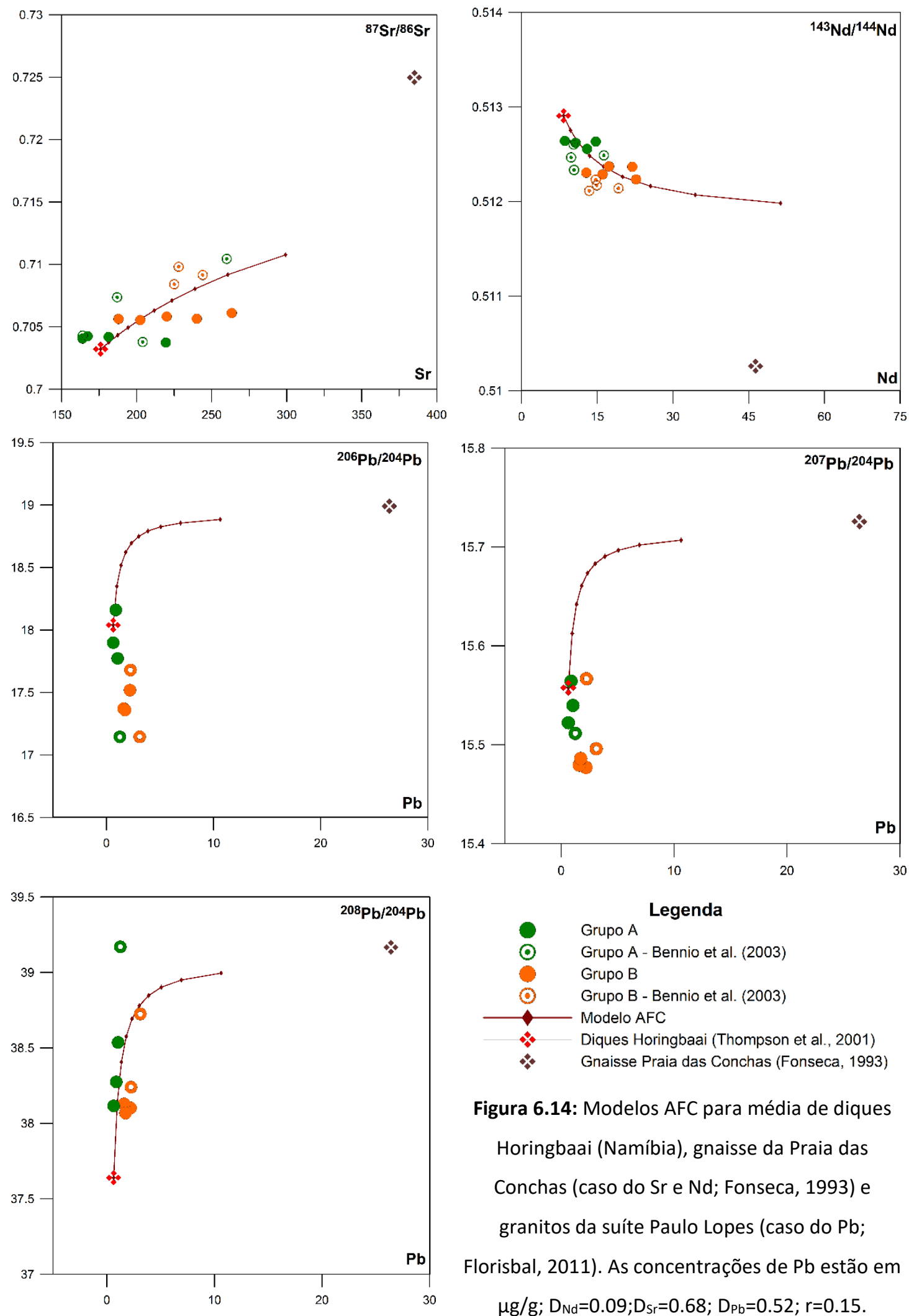

Figura 6.14: Modelos AFC para média de diques Horingbaai (Namíbia), gnaisse da Praia das Conchas (caso do Sr e Nd; Fonseca, 1993) e granitos da suíte Paulo Lopes (caso do $\mathrm{Pb}$; Florisbal, 2011). As concentrações de Pb estão em $\mu \mathrm{g} / \mathrm{g} ; D_{N d}=0.09 ; D_{S r}=0.68 ; D_{P b}=0.52 ; r=0.15$.

Vale ressaltar que a modelagem de processos AFC pelas equações de DePaolo (1981) desconsidera processos como a mudança dos coeficientes de partição e da razão entre a massa assimilada e fracionada ao longo do processo de diferenciação na câmara magmática, o que limita muito seu alcance de descrição. Entretanto, considerando o 
intervalo de variação do conteúdo de $\mathrm{MgO}$ dos diques estudados $(5,27 \leq \mathrm{MgO} \leq 8,44 \%)$, tais mudanças não deveriam ser muito significativas.

Modelos envolvendo misturas simples entre reservatórios mantélicos EMI, MORB e DMM (Zindler \& Hart, 1986; Workman \& Hart, 2005; Jackson \& Dasgupta, 2005) também foram testados, mas não obtiveram sucesso em ajustar o comportamento dos dados de $\mathrm{Sr}, \mathrm{Nd}$ e $\mathrm{Pb}$ simultaneamente. Estas dificuldades sugerem uma grande complexidade da fonte mantélica abaixo da Região dos Lagos, no Domínio Tectônico de Cabo Frio, provavelmente portador de grandes heterogeneidades composicionais. Tal hipótese é reforçada por estudos recentes, que sugerem que os sucessivos e longos processos de subducção regionais, ligados à amalgamação do Gondwana, podem ter se estendido por mais de $250 \mathrm{Ma}$, do período Toniano ao Ediacarano (Peixoto et al., 2016; Schmitt et al., 2016).

Uma vez que a crosta continental parece não ter participado significativamente na gênese dessas rochas, as assinaturas isotópicas observadas devem ser devidas a fontes mantélicas com diferentes características. Neste caso, os diagramas multielementares (seção 6.1.2) das rochas do grupo A, que mostram que a razões de La/NbPM próximas ou menores que $1\left(0,91 \leq\left[\mathrm{La} / \mathrm{Nb}_{\mathrm{PM}}\right] \leq 1,12\right)$, sugerem que não houve envolvimento de fonte mantélica influenciada (metassomatizada) por processos de subducção (Rollinson, 1993), a exemplo dos derrames da PMP. O grupo B, por sua vez, apresenta valores superiores $\left(1,22 \leq\left[\mathrm{La} / \mathrm{Nb}_{\mathrm{PM}}\right] \leq 1,42\right)$ e tal contraste é indicativo de que a fonte mantélica pode ter sido afetada por tais processos. A diferença nas razões $\mathrm{La} / \mathrm{Nb}_{\mathrm{PM}}$ entre os grupos A e B é ilustrada na figura 6.15.

Outro comportamento notável nos padrões de diagramas multielementares é o das razões $\mathrm{Rb} / \mathrm{BapM}$, em sua maioria superiores a 1 (grupo $\mathrm{A}: 1,06 \leq[\mathrm{Rb} / \mathrm{Ba}]_{\mathrm{PM}} \leq 1,85$; grupo B: $0,68 \leq[\mathrm{Rb} / \mathrm{Ba}]_{\mathrm{PM}} \leq 2,20$; figura 6.15). Seu crescimento não é acompanhado por diminuição significativa nos teores de $\mathrm{MgO}$, o que seria esperado se os grupos $\mathrm{A}$ e $\mathrm{B}$ estivessem relacionados a processos envolvendo contaminação de material crustal (como se observa para os magmas Esmeralda e Gramado da PMP), reforçando o envolvimento de magmas parentais distintos. Entretanto, parte da variação observada nas razões $\mathrm{Rb} / \mathrm{Ba}$ pm pode ser devida à alta mobilidade do $\mathrm{Rb}$.

O aumento da concentração de elementos traço fortemente incompatíveis também não está associado a uma mudança progressiva da razão ${ }^{87} \mathrm{Sr} /{ }^{86} \mathrm{Sr}$ (figura 6.16), 
mostrando mais uma vez a participação de fontes distintas na gênese dos grupos A e B, contrariamente ao que foi proposto por Bennio et al. (2003).
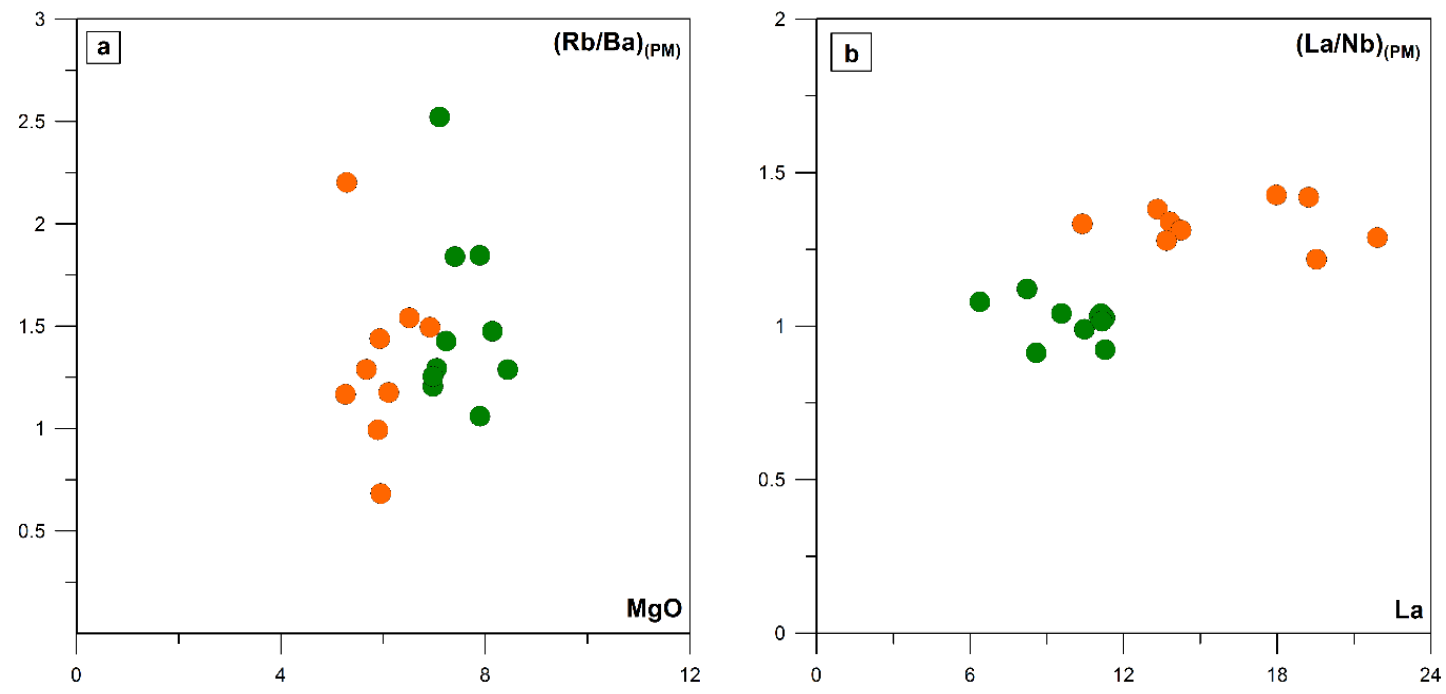

Figura 6.15: Diagramas de razões de elementos incompatíveis normalizados pelo manto primitivo em função de MgO (\%) e La ( $\mu \mathrm{g} / \mathrm{g}$ ) dos grupos A (verde) e B (laranja).

\subsection{Algumas considerações petrográficas e análise por MEV e EDE}

Antes de qualquer determinação geocronológica, é fundamental investigar cuidadosamente os processos de alteração atuantes nas fases minerais a serem datadas. No presente estudo, a petrografia foi usada como uma ferramenta para selecionar as melhores amostras para a datação pelo método ${ }^{40} \mathrm{Ar} /{ }^{39} \mathrm{Ar}$, e também no auxílio da interpretação dos espectros de idade obtidos.

De maneira geral, a composição mineralógica dos diques coletados consiste em plagioclásio, piroxênio e magnetita; olivina, anfibólio, biotita e apatita figuram como minerais acessórios. Argilominerais, como sericita e clorita (esta última também na forma de veios), pirita e calcopirita são encontrados como minerais secundários, geralmente associados ao clinopiroxênio, ou possivelmente substituindo olivina. Há ocorrências de argilominerais muito finos que não foram identificados. As texturas das rochas variam majoritariamente de afaníticas a faneríticas finas e, em termos petrográficos, variam entre afíricas e porfiríticas. Não foram detectadas variações petrográficas significativas entre os grupos A e B. A seguir, é apresentada uma breve caracterização das quatro amostras selecionadas para as datações ${ }^{40} \mathrm{Ar} /{ }^{39} \mathrm{Ar}$ através de microscopia óptica e análise em MEV, com EDE acoplado. 

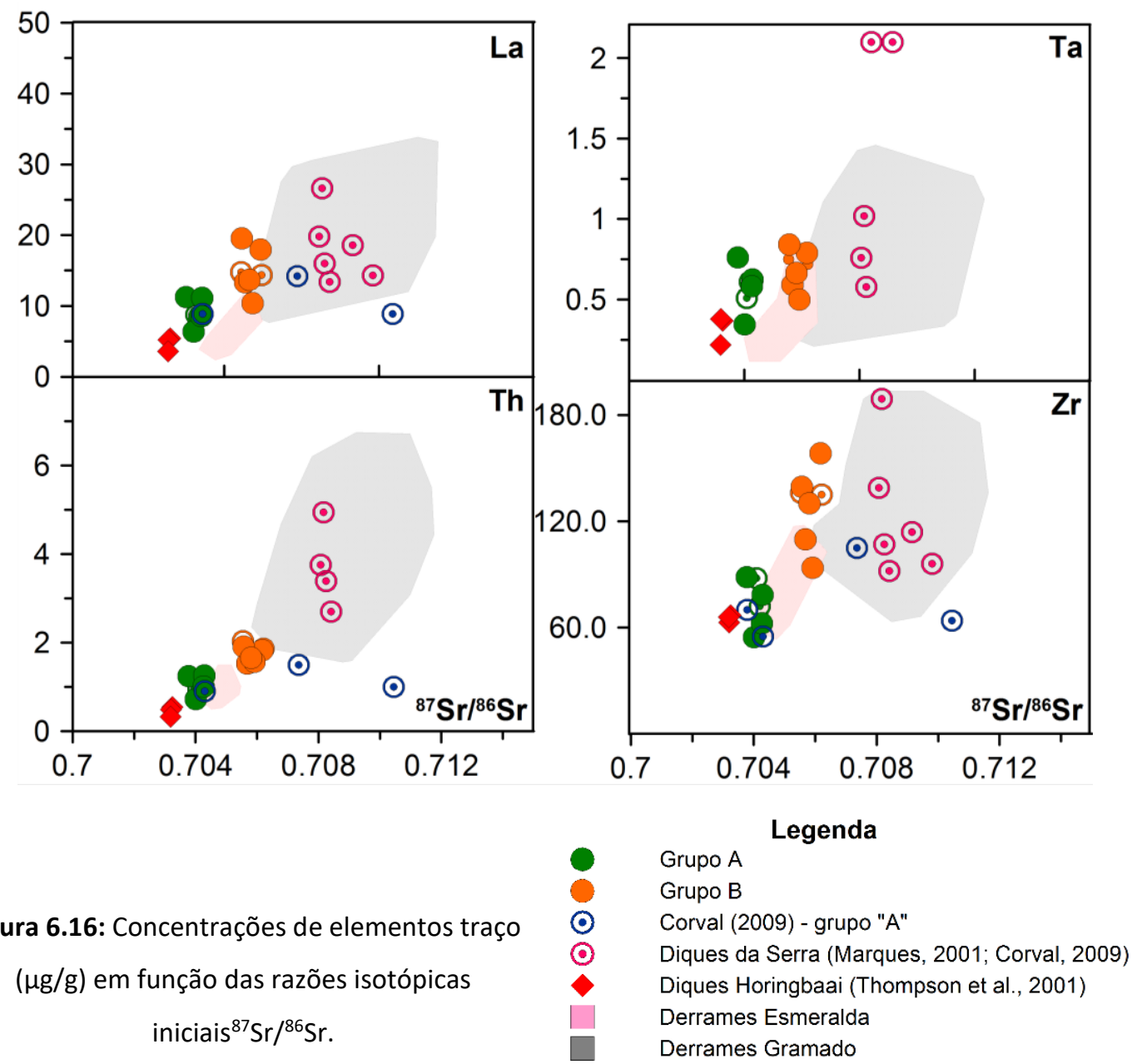

\subsubsection{GRUPO A}

LM-DA-203 - A amostra, proveniente de Cabo Frio, apresenta textura fanerítica fina, com poucos sinais de alteração, e teve alíquotas de plagioclásio, anfibólio e biotita selecionadas para as análise ${ }^{40} \mathrm{Ar} /{ }^{39} \mathrm{Ar}$. Muitos dos cristais de plagioclásio (acima de 800 $\mu \mathrm{m})$, em geral, ocorrem em aglomerados e contêm diversas pequenas inclusões de apatita e piroxênio. Tais cristais são normalmente pouco afetados por sericitização; quando presente, a sericita ocorre em regiões centrais e nas bordas de zonas de contato com cristais de piroxênio (figuras 6.17a). Os anfibólios são mais raros e apresentam distribuição homogênea (figura 6.17b), sendo que os maiores cristais (cerca de $500 \mu \mathrm{m}$ ) podem possuir padrões levemente zonados.

Análises realizadas em MEV com EDE acoplado permitiram a detecção inclusões de magnetita, piroxênio, apatita, pirita e calcopirita em cristais de plagioclásio, sendo que os dois primeiros minerais são comuns em zonas de fratura (figura 6.17c). Pequenos 
cristais de anfibólio também puderam ser identificados em regiões de contato entre plagioclásios e piroxênios. O zoneamento composicional dos plagioclásios foi raramente identificado, e a composição anortítica mostrou-se predominante. Bordas mais albíticas estão presentes de modo heterogêneo nos fenocristais (figura 6.17d), os quais possuem também variações nos teores de Ca, com ocorrências de zonas mais enriquecidas em regiões intermediárias dos grãos (zoneamento oscilante). As raras regiões afetadas por sericitização apresentam picos de K nas análises de EDE.
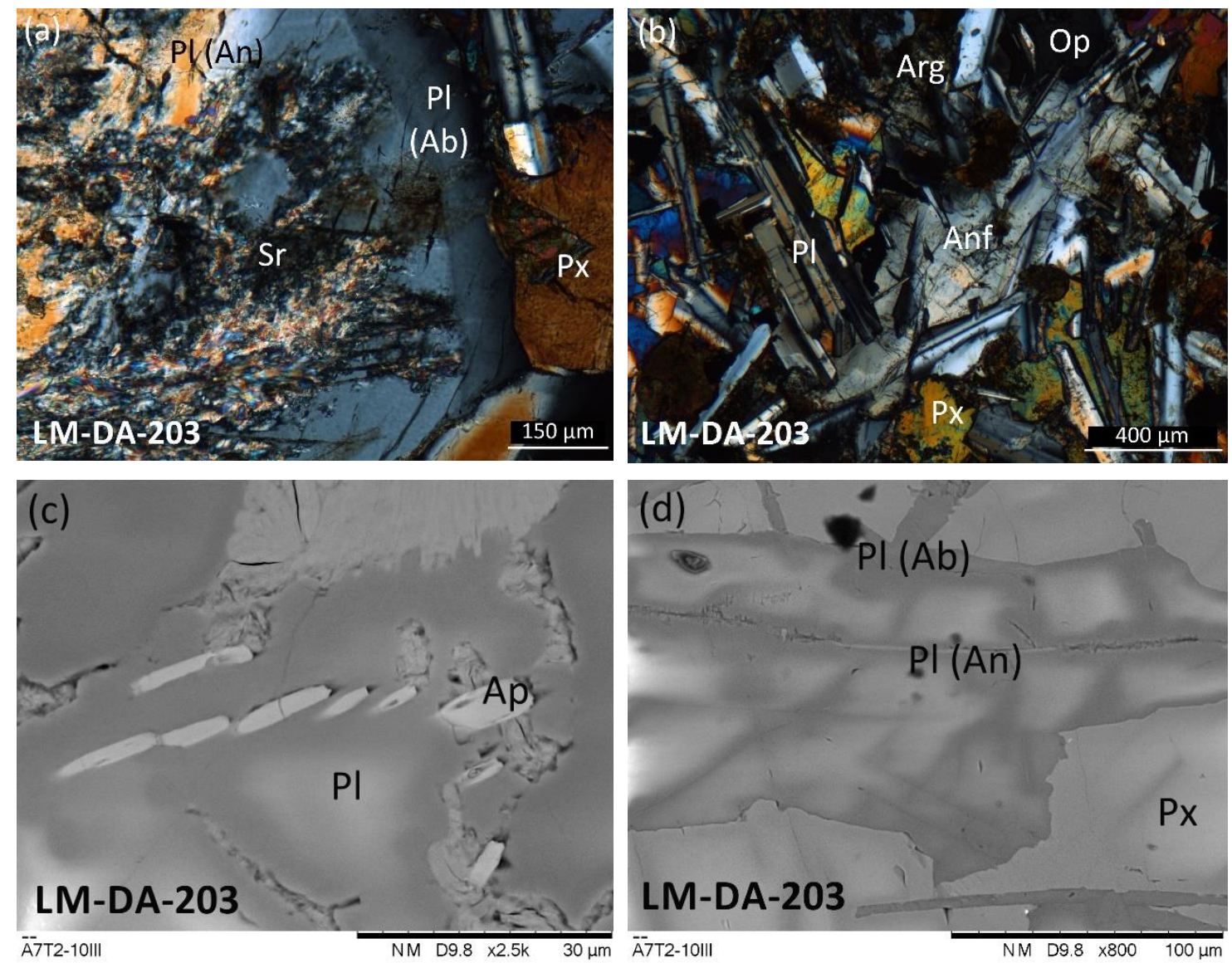

Figura 6.17: (a) Fotomicrografia com polarizador cruzado de plagioclásio (PI) altamente sericitizado em sua porção anortítica (An); as bordas albíticas (Ab) permanecem frescas. (b) Fotomicrografia com polarizador cruzado de anfibólio (Anf) em meio a cristais de plagioclásio e piroxênio ( $\mathrm{Px}$ ), além de argilominerais (Arg). (c) Inclusões de apatita (Ap) em fenocristal de plagioclásio, associadas a zonas de fratura (imagem BSE). (d) Padrão irregular de zoneamento de fenocristal de plagioclásio (imagem BSE).

LM-DA-150 - A amostra é proveniente de um dique afanítico de cerca de 2,5 metros de espessura, localizado no município de Arraial do Cabo, e teve alíquotas de plagioclásio selecionadas para datação ${ }^{40} \mathrm{Ar} /{ }^{39} \mathrm{Ar}$. Em termos petrográficos, sua textura 
é porfirítica, com fenocristais de plagioclásio e piroxênio. A sericitização está presente, essencialmente, em regiões centrais dos fenocristais de plagioclásio (figura 6.18c).

Análises de MEV e EDE puderam detectar a presença de sulfetos (pirita e calcopirita) e apatita como inclusões nos cristais de plagioclásio (figuras 6.18a e 6.18b). O zoneamento composicional, por sua vez, é acentuado tanto nos fenocristais como nos cristais de matriz. Regiões centrais dos grãos apresentam composição anortítica, e bordas mais albíticas ocorrem de forma mais homogênea do que o padrão encontrado na amostra LM-DA-203.
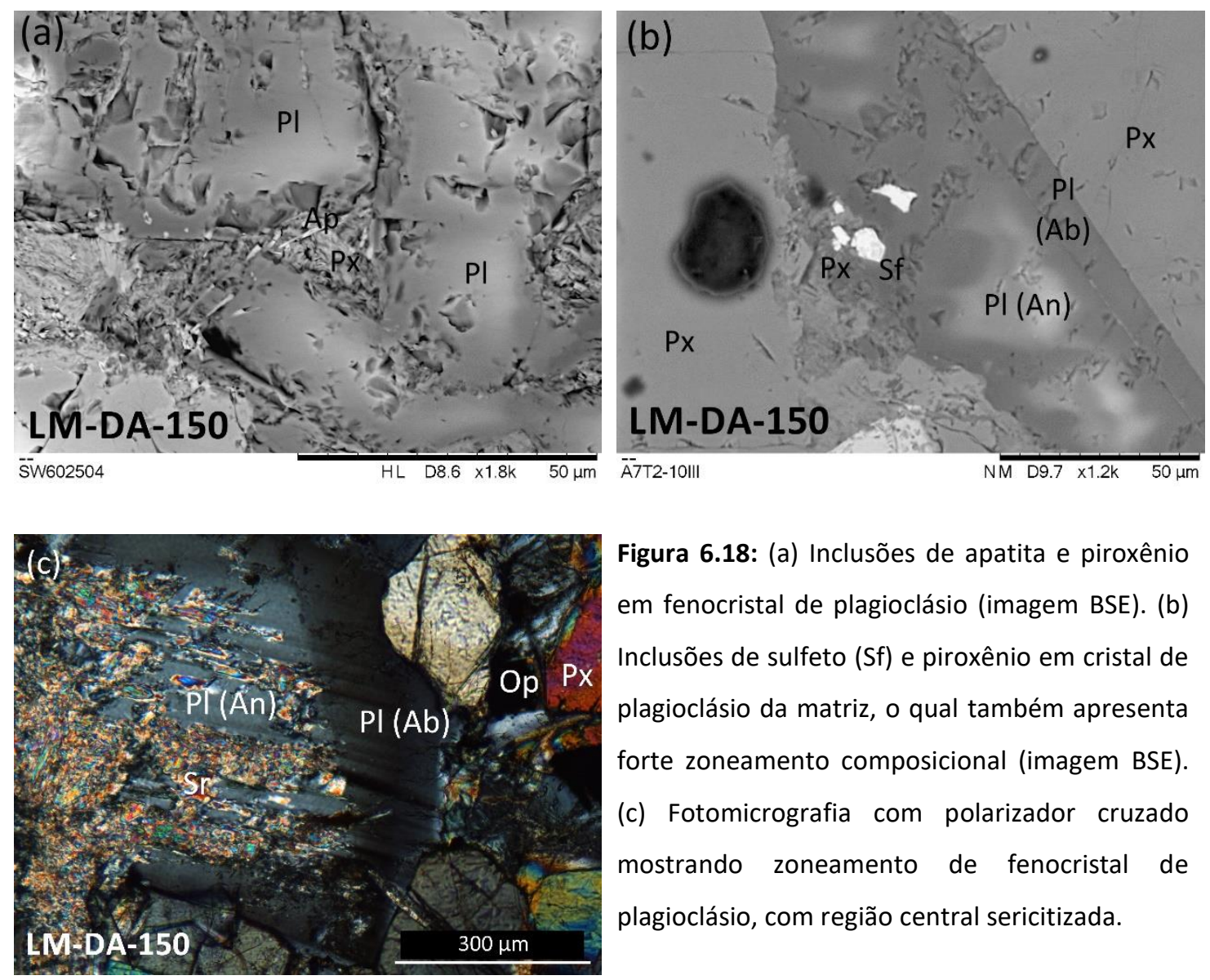

Figura 6.18: (a) Inclusões de apatita e piroxênio em fenocristal de plagioclásio (imagem BSE). (b) Inclusões de sulfeto (Sf) e piroxênio em cristal de plagioclásio da matriz, o qual também apresenta forte zoneamento composicional (imagem BSE). (c) Fotomicrografia com polarizador cruzado mostrando zoneamento de fenocristal de plagioclásio, com região central sericitizada.

$L M-B Z-5 R$ - A amostra, proveniente de um dique de textura afanítica de Búzios, apresenta textura porfirítica o ponto de vista microscópico, com fenocristais de piroxênio e plagioclásio, a qual teve grãos de plagioclásio e rocha total analisados por ${ }^{40} \mathrm{Ar} /{ }^{39} \mathrm{Ar}$. Neste dique, as ocorrências de anfibólio são mais raras e os argilominerais encontram-se presentes entre grãos de plagioclásio e piroxênio, sendo com frequência associados a aglomerados de magnetita. Os cristais de plagioclásio também são afetados 
por inclusões de magnetita e apresentam zoneamento composicional facilmente detectável por meio de microscópio óptico (figura 6.19b).

A maior parte dos fenocristais de plagioclásio não apresenta alteração (figura 6.19a); no entanto, quando presente, a sericitização mostra-se intensa (figura 6.19c). Os minerais da matriz, por sua vez, são geralmente frescos. Análises em MEV e EDE não puderam ser realizadas em função de efeitos de carga nas lâminas delgadas, cuja causa não foi investigada.
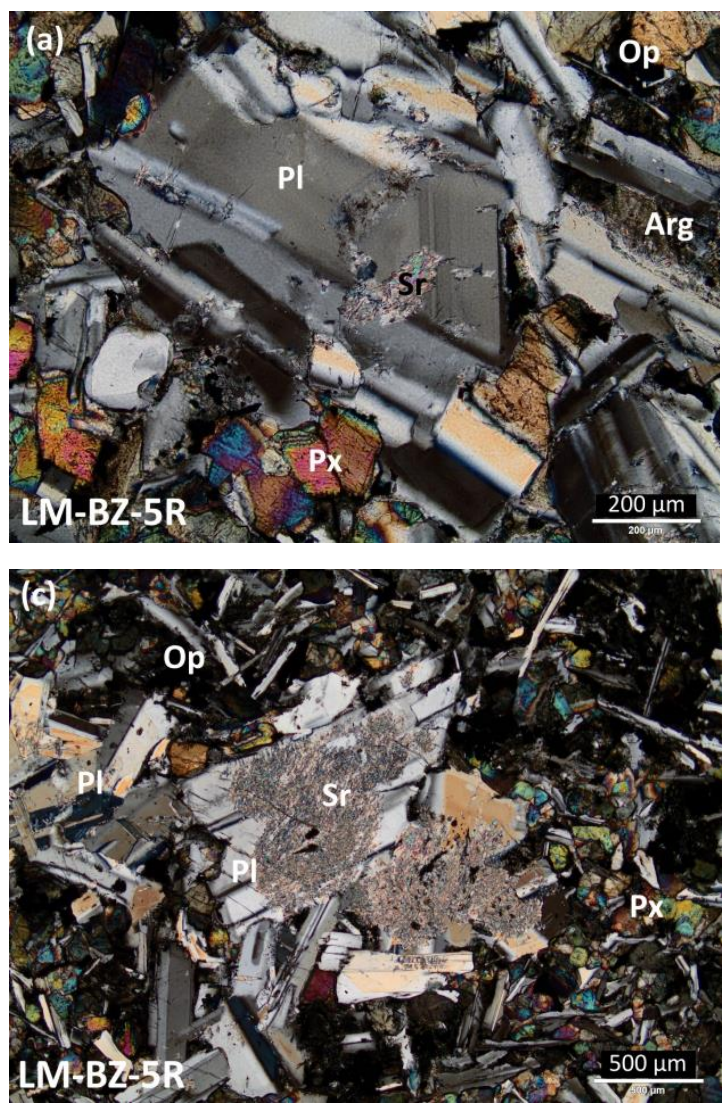

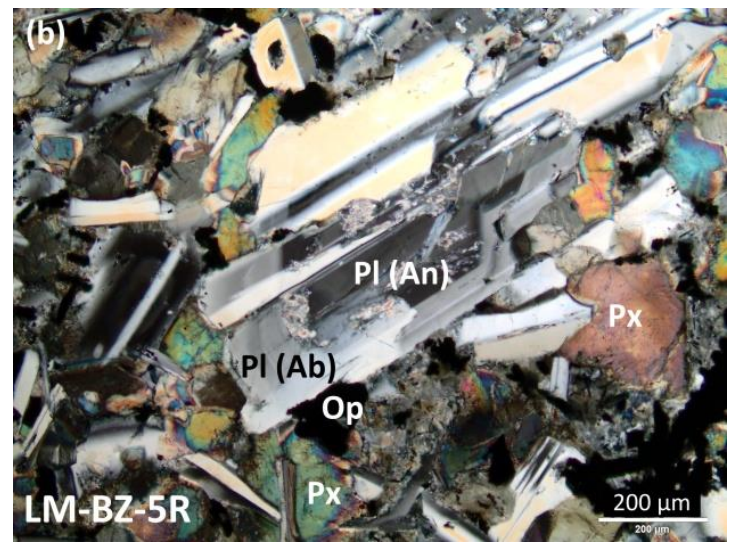

Figura 6.19: (a) Fotomicrografia com polarizador cruzado de fenocristal de plagioclásio com pouca sericitização em meio à matriz de plagioclásios e

clinopiroxênios. (b) Fotomicrografia com polarizador cruzado mostrando forte padrão de zoneamento de fenocristal de plagioclásio, com pequenas ocorrências de sericita. (c) Fotomicrografia sob luz polarizada mostrando a ocorrência de acentuada sericitização em fenocristais de plagioclásio.

\subsubsection{GRUPO B}

LM-DA-161 - A amostra foi extraída de um dique de textura afanítica de Arraial do Cabo, cuja datação ${ }^{40} \mathrm{Ar} /{ }^{39} \mathrm{Ar}$ foi realizada em rocha total. Do ponto de vista petrográfico, a textura é porfirítica, com fenocristais de plagioclásio e piroxênio (estes últimos frequentemente afetados por cloritização). As ocorrências de argilominerais concentram-se nas bordas dos cristais de piroxênio, e podem ter se originado de processos de alteração de olivina (figura 6.20a). 
As investigações promovidas em MEV e EDE detectaram numerosas inclusões de sulfetos e magnetita nos cristais de piroxênio e plagioclásio (especialmente em fenocristais). Estes últimos se apresentam zonados com padrões muito heterogêneos, e podem apresentar ocorrências de argilominerais (figura 6.20c). No entanto, é importante ressaltar que processos de sericitização não foram identificados (figura 6.20b). Pequenos grãos de anfibólio (cerca de $100 \mu \mathrm{m}$ ) estão presentes de modo homogêneo, sem um padrão aparente.
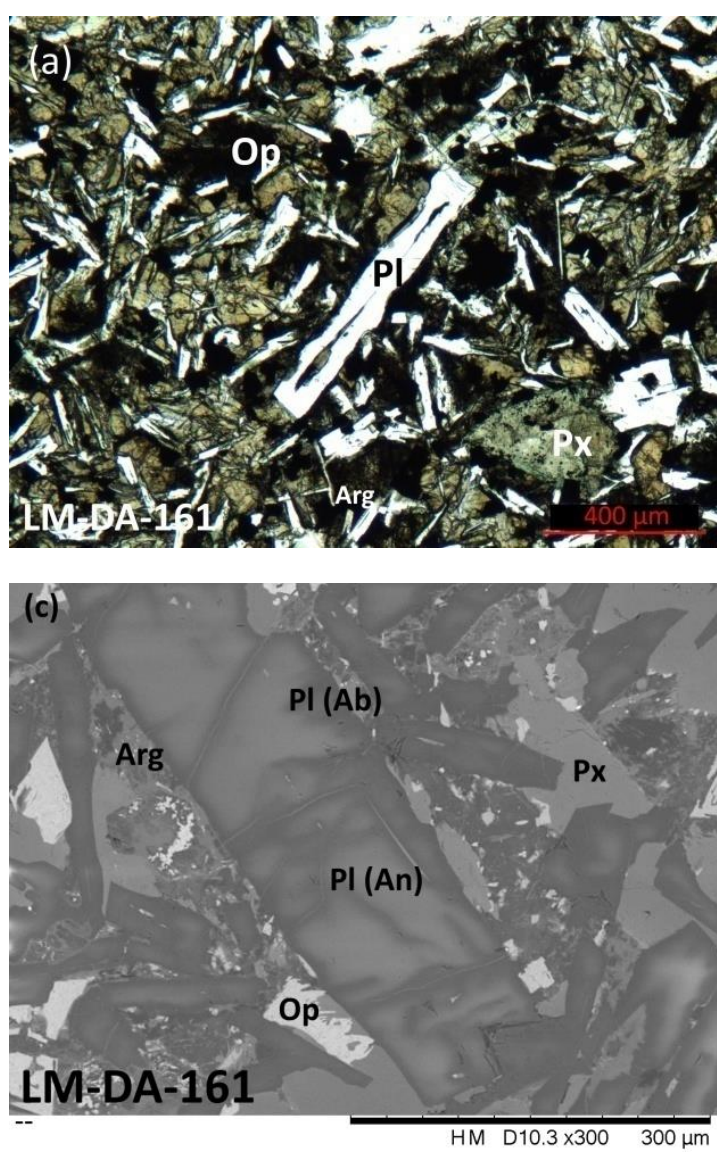

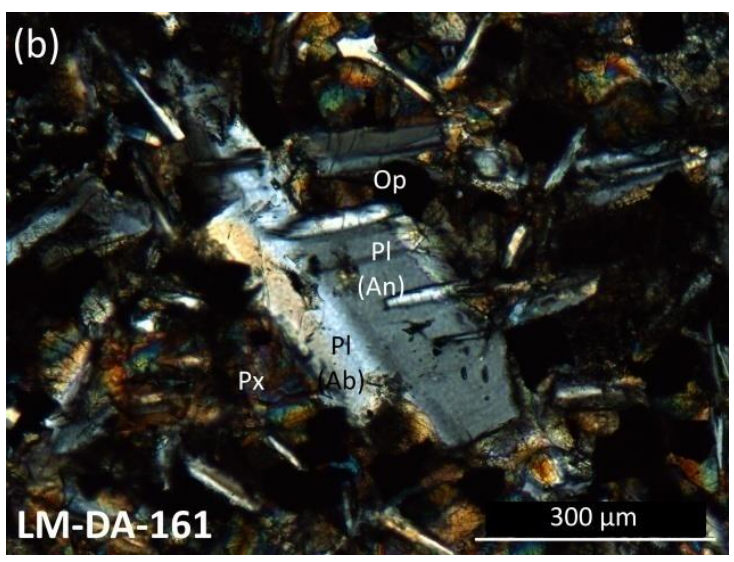

Figura 6.20: (a) Fotomicrografia sob luz polarizada mostrando fenocristal de plagioclásio com reabsorção na parte central, e apresentando argilominerais nas bordas. (b) Fotomicrografia com polarizador cruzado mostrando fenocristal de plagioclásio zonado e livre de sericita. (c) Padrão de zoneamento de fenocristais de plagioclásio (imagem BSE). 


\subsection{Geocronologia ${ }^{40} \mathrm{Ar} /{ }^{\beta 9} \mathrm{Ar}$}

\subsubsection{GRUPO A}

LM-DA-203 - As análises das duas alíquotas encapsuladas de plagioclásio sericitizado resultaram em platôs de 106,05 $\pm 0,52$ e 106,89 $\pm 0,54 \mathrm{Ma}$, e idades integradas de $106,3 \pm 3,6$ e 108,0 $\pm 0,9 \mathrm{Ma}$ (figura 6.21). O aumento das incertezas nas idades aparentes de altas temperaturas coincidiu com a queda na liberação de ${ }^{40} \mathrm{Ar}$. As razões $\mathrm{K} / \mathrm{Ca}$ foram compatíveis com os valores esperados para uma mistura entre plagioclásio e sericita, permanecendo constantes durante os intervalos de liberação do ${ }^{39} \mathrm{Ar}$ correspondentes aos platôs. Análises de plagioclásios alterados podem fornecer a idade real dos plagioclásios se a cristalização dos mesmos e a sericitização forem contemporâneas; caso contrário, se a alteração for mais recente, a sericita pode consideravelmente reduzir os valores de idade dos platôs, já que seu teor de K é muito maior do que aquele do plagioclásio.

O primeiro nível de cada espectro de idades corresponde à análise de recuo; os baixos valores de ${ }^{39} \mathrm{Ar}$ liberado nessa fase indicam que não ocorreu deslocamento significativo de ${ }^{39} \mathrm{Ar}$ durante a irradiação. Uma das alíquotas (9159) forneceu um platô menor em seu espectro de idades, mas ainda assim o aumento gradual das idades aparentes nas últimas etapas de alta temperatura não caracteriza o padrão usual de "sela" causado por excesso de Ar. Tal padrão, marcado por altos valores de idades aparentes iniciais e finais, é muito comum em análises de minerais com baixos teores de K, como o plagioclásio cálcico (McDougall \& Harrison, 1999) e, no geral, considera-se que as menores idades aparentes devem refletir a idade máxima da amostra. Esse comportamento pode estar associado à presença de inclusões ricas em K e Ar presentes nos cristais, sendo que inclusões fluídas tendem a liberar Ar nos estágios iniciais de temperatura e inclusões sólidas nos estágios finais (Boven et al., 2001; Kelley et al., 2002).

Para a confecção da isócrona inversa e dos diagramas de probabilidade de idade foram utilizados os dados de ambas as alíquotas (figura 6.22) e apenas os valores correspondentes aos platôs foram considerados para o ajuste de reta (o mesmo procedimento foi seguido para as outras amostras). A idade obtida na isócrona inversa foi de 106,22 $\pm 0,53 \mathrm{Ma}$, com desvio quadrático médio ponderado ("mean square weighed deviation" ou MSWD) de 1,6 e razão ${ }^{36} \mathrm{Ar} /{ }^{40} \mathrm{Ar}$ inicial compatível com os valores 
atmosféricos (que indica pouca influência de excesso de Ar nas análises). Os diagramas de probabilidade de idade apresentam picos em valores similares (figura 6.23).

Para uma cápsula contendo grãos de plagioclásio fresco (que consistem numa mistura de grãos não sericitizados e de bordas frescas de grãos sericitizados), o espectro de idades apresentou um platô em 95,6士1,2 Ma (figura 6.24), que contrasta com os valores esperados, que deveriam ser similares ou, ainda, maiores que aqueles obtidos anteriormente para plagioclásios em parte sericitizados. Os comportamentos observados na isócrona $(97,2 \pm 1,8 \mathrm{Ma}$; MSWD=0,52) e no diagrama de probabilidade de idade $(95,7 \pm 0,56 \mathrm{Ma})$ são semelhantes e não indicam influência de excesso de Ar (figuras 6.25 e 6.26$)$.

Tais resultados podem ser explicados por duas hipóteses não excludentes. A primeira, corroborada pelos valores de razão K/Ca das análises, é de que os grãos de plagioclásio presentes na cápsula não eram totalmente frescos, apresentando quantidade considerável de sericita (pouco provável em vista dos cuidados tomados na preparação das amostras). A segunda é de que as bordas albíticas frescas da alíquota podem ser responsáveis pela idade mais recente, se sua ocorrência se deve a processos de alteração (albitização) e não por zoneamento primário decorrente de diferenciação durante a cristalização dos minerais. Neste caso, o platô obtido pode indicar a idade máxima de albitização (um exemplo clássico deste processo em magmatismo intrusivo é descrito em Nemec, 1966). Tal hipótese é reforçada pelo fato de que as porções sódicas dos plagioclásios se acoplam efetivamente com o feixe do laser em altas temperaturas, o que explicaria a ocorrência do platô em estágios intermediários e finais do espectro. Além disso, a presença heterogênea de bordas albíticas detectada pelas análises EDS também coincide com o comportamento esperado em casos deste tipo de alteração. Tal resultado é importante porque sugere que mais de um processo de alteração pode ter influenciado consideravelmente as análises de Ar em grãos de plagioclásio dos diques aqui investigados.

Foram também obtidos resultados para os grãos encapsulados de anfibólio primário e biotita desta mesma rocha. Ambas as fases minerais foram selecionadas em conjunto, de modo que a composição das alíquotas consistiu em cerca de $90 \%$ de anfibólio e $10 \%$ de biotita. A mistura foi detectada durante as análises por aquecimento gradual da alíquota 9169, por conta do padrão de temperaturas necessário à liberação 
do gás. No entanto, tanto o sinal da sequência de baixas temperaturas ( $10 \%$ de ${ }^{39} \mathrm{Ar}$ liberados, correspondentes à análise da biotita), quanto aquele de altas temperaturas (90\% de ${ }^{39} \mathrm{Ar}$ liberados, provenientes grãos de anfibólio) forneceram idades similares e

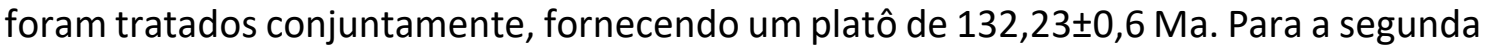
alíquota (9170), a programação de aquecimento foi adaptada para a presença de anfibólios e o espectro de idades obtido indica valor semelhante, de 132,1士1,6 Ma (figura 6.27), que é corroborado pela isócrona obtida com valores de ambas as alíquotas, cuja idade é $132,53 \pm 0,75 \mathrm{Ma}(\mathrm{MSWD}=1,5$; figura 6.28). O mesmo ocorre nos diagramas de probabilidade de idade (figura 6.29).

A discordância de resultados das alíquotas de plagioclásio e anfibólio/biotita provavelmente marca uma história termocronológica. Grãos de anfibólio apresentam maiores temperaturas de fechamento para difusão de Ar e sua idade é mais próxima da idade real de intrusão do corpo magmático. Cabe destacar que a idade obtida para os anfibólios é quase contemporânea àquela reportada por Thiede \& Vasconcelos (2010) para os derrames basálticos da PMP. Assim, se a intrusão do corpo ocorreu em profundidade relativamente alta, o gradiente térmico da crosta pode ter retardado o fechamento do sistema nos grãos de plagioclásio, até que posterior denudação do terreno tenha ocorrido, de forma a promover o resfriamento rápido e afloramento do dique. Neste caso, os plagioclásios marcariam a idade deste último processo. 


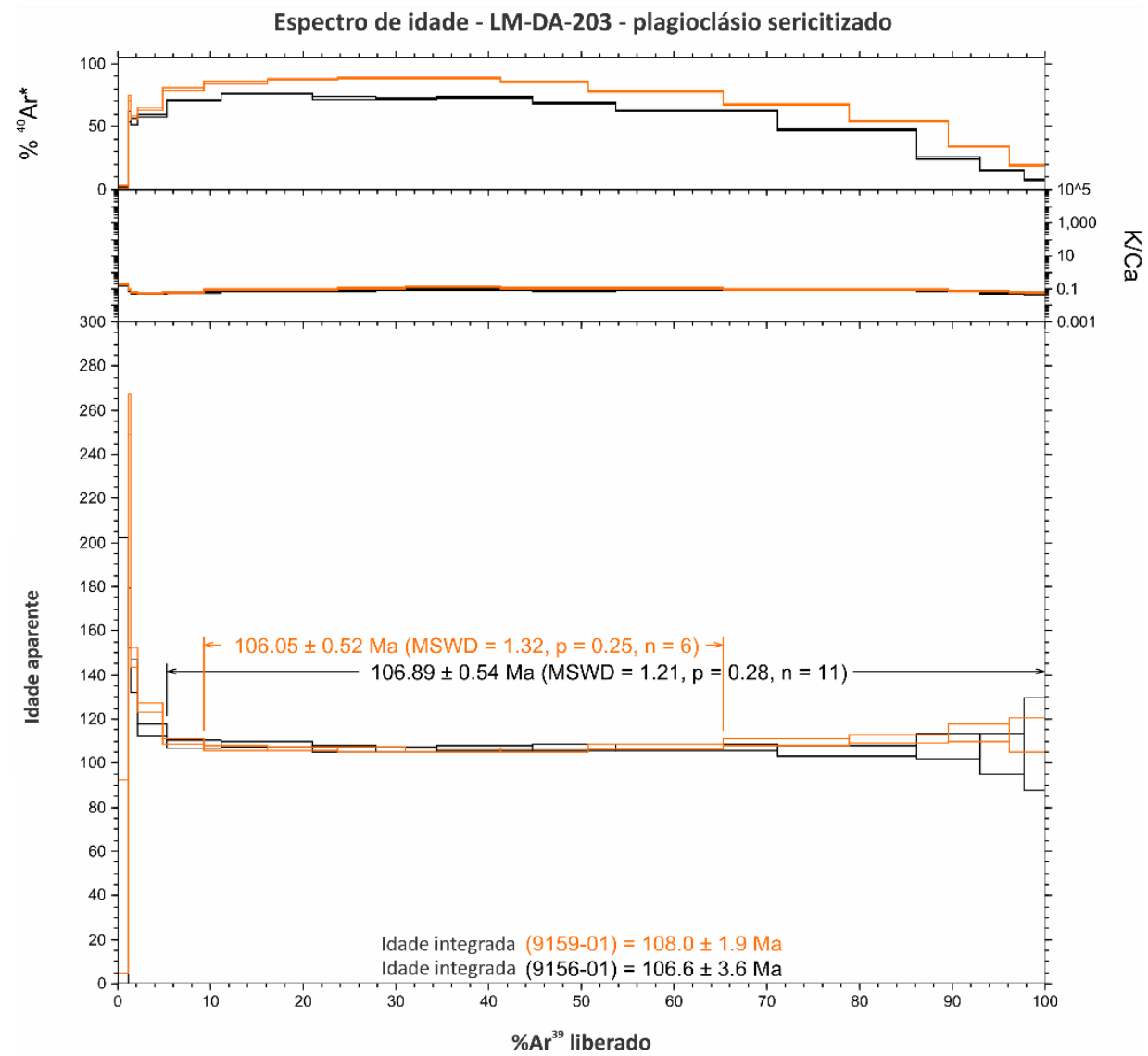

Figura 6.21: Espectro de idade das alíquotas de plagioclásio sericitizado da amostra LM-DA-203.

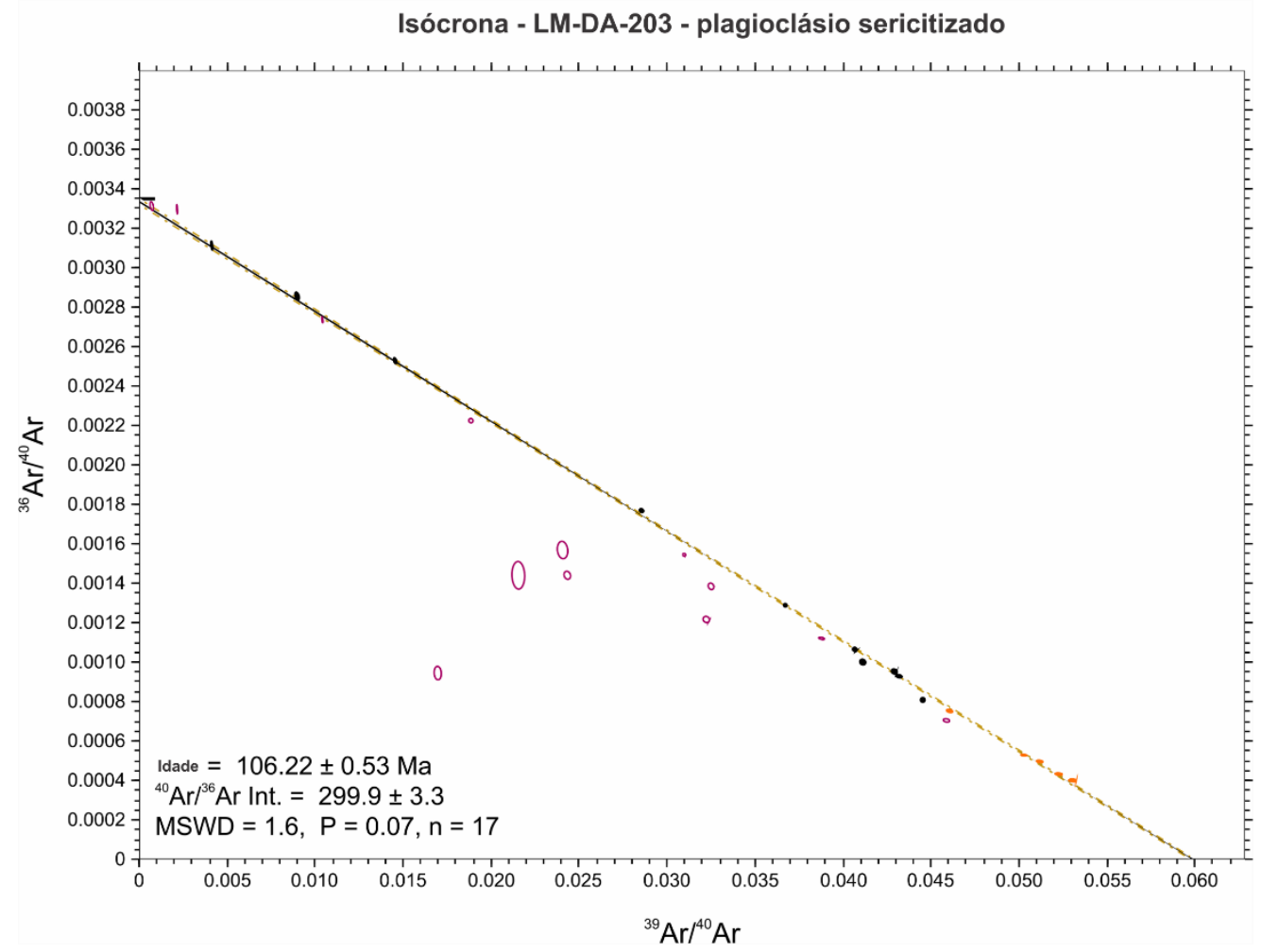

Figura 6.22: Isócrona das alíquotas de plagioclásio sericitizado da amostra LM-DA-203. 


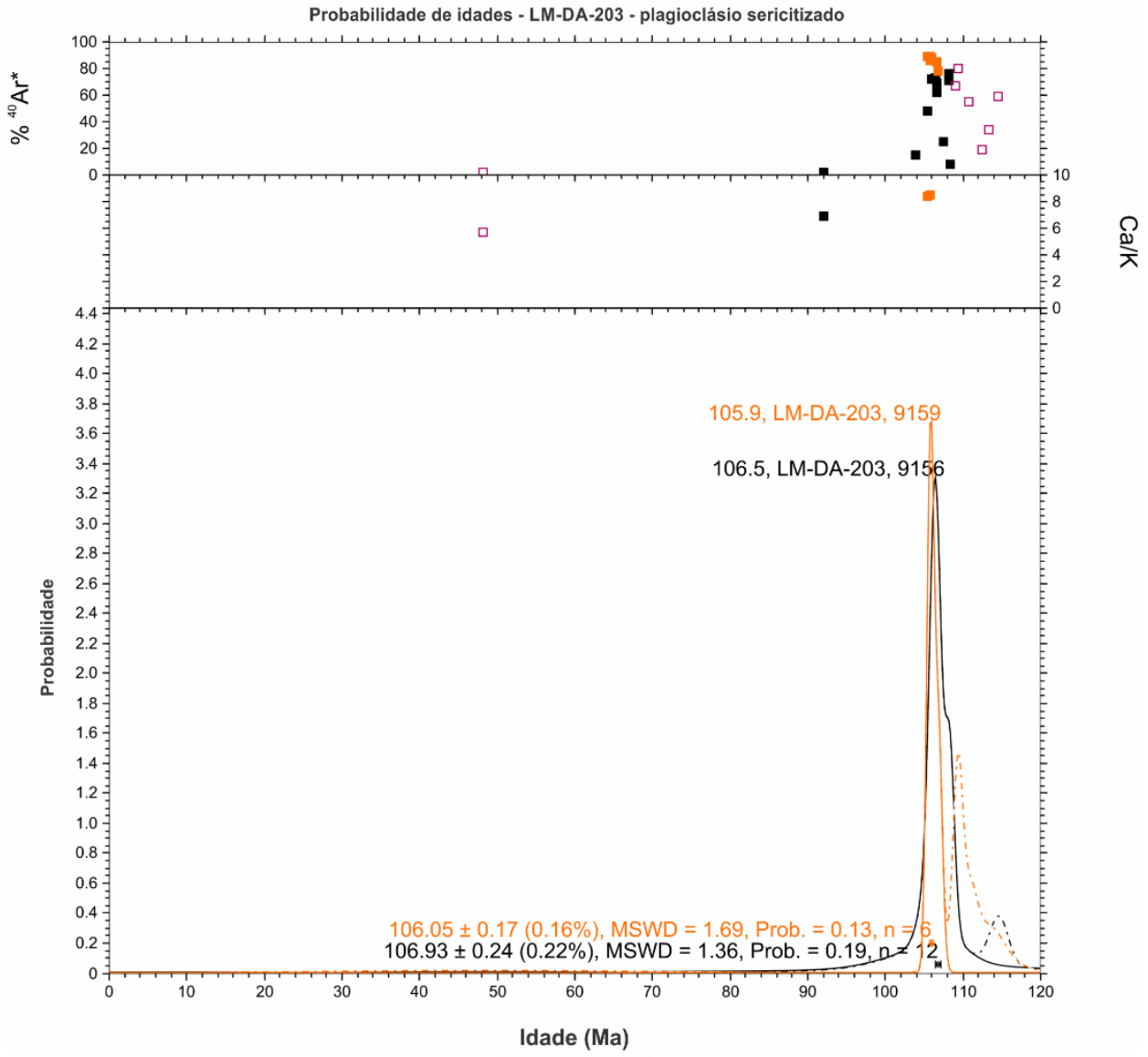

Figura 6.23: Diagrama de probabilidade de idade das alíquotas de plagioclásio sericitizado da amostra LM-DA-203. 


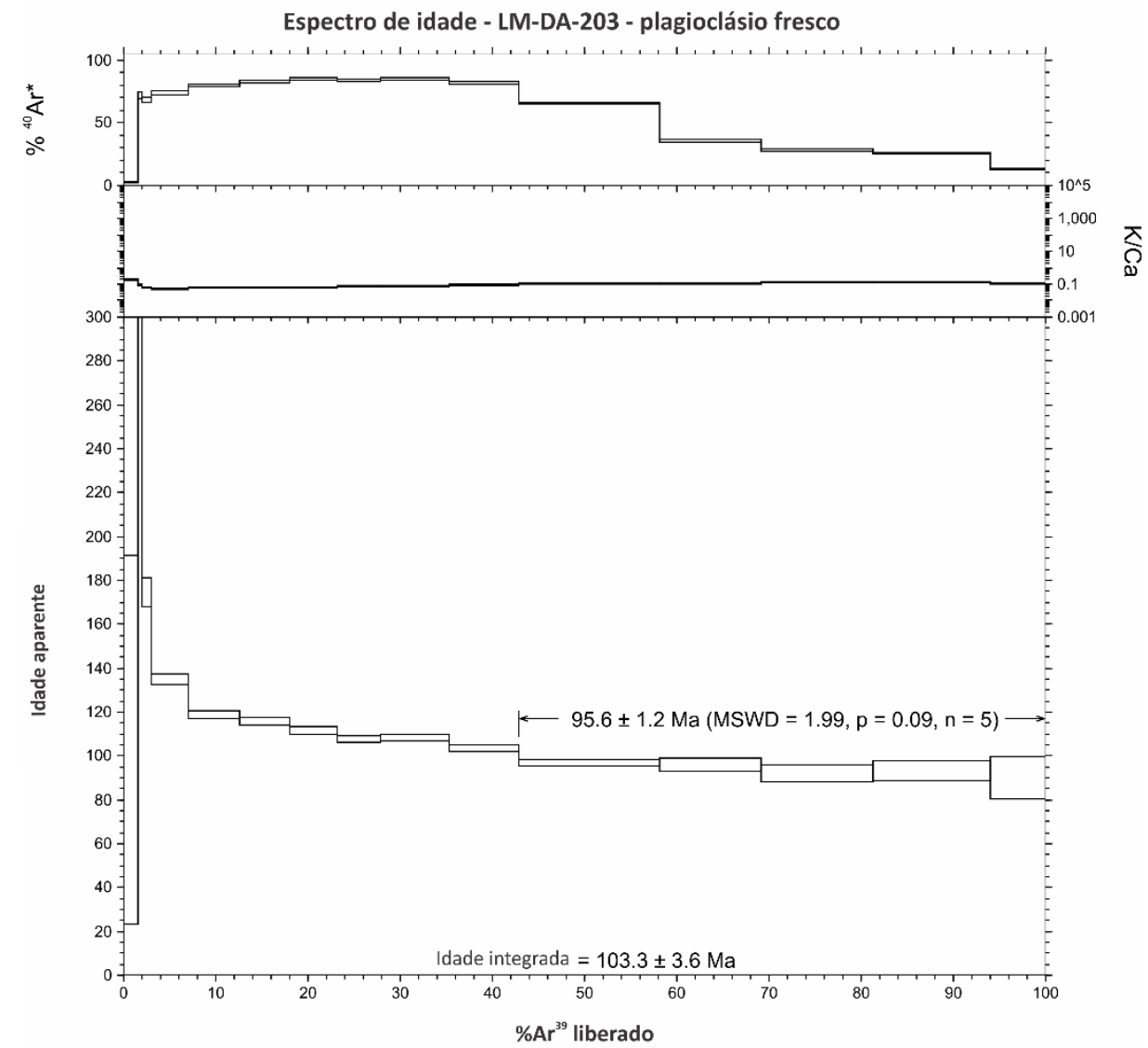

Figura 6.24: Espectro de idade da alíquota de plagioclásio fresco da amostra LM-DA-203.

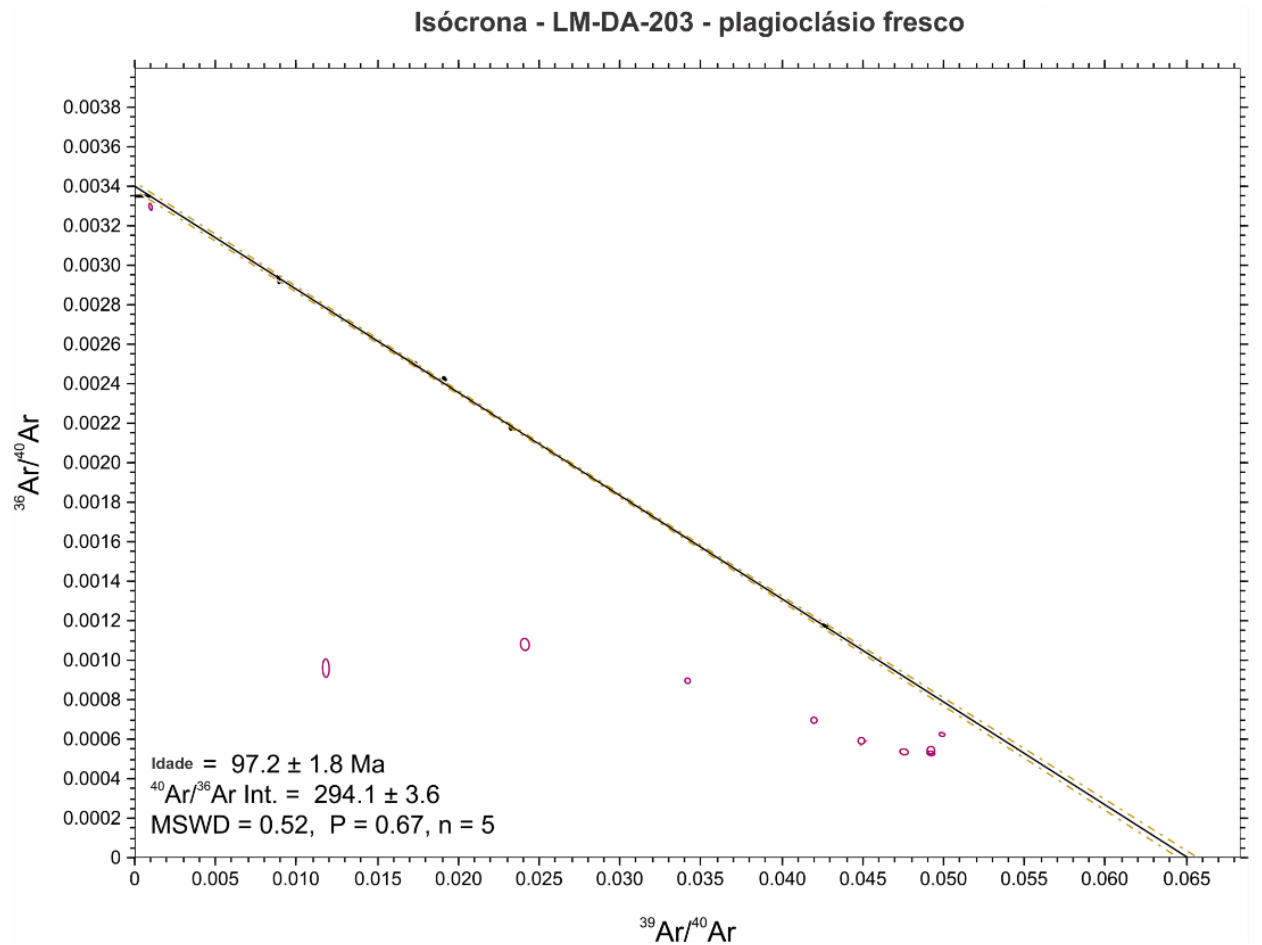

Figura 6.25: Isócrona das alíquotas de plagioclásio fresco da amostra LM-DA-203. 


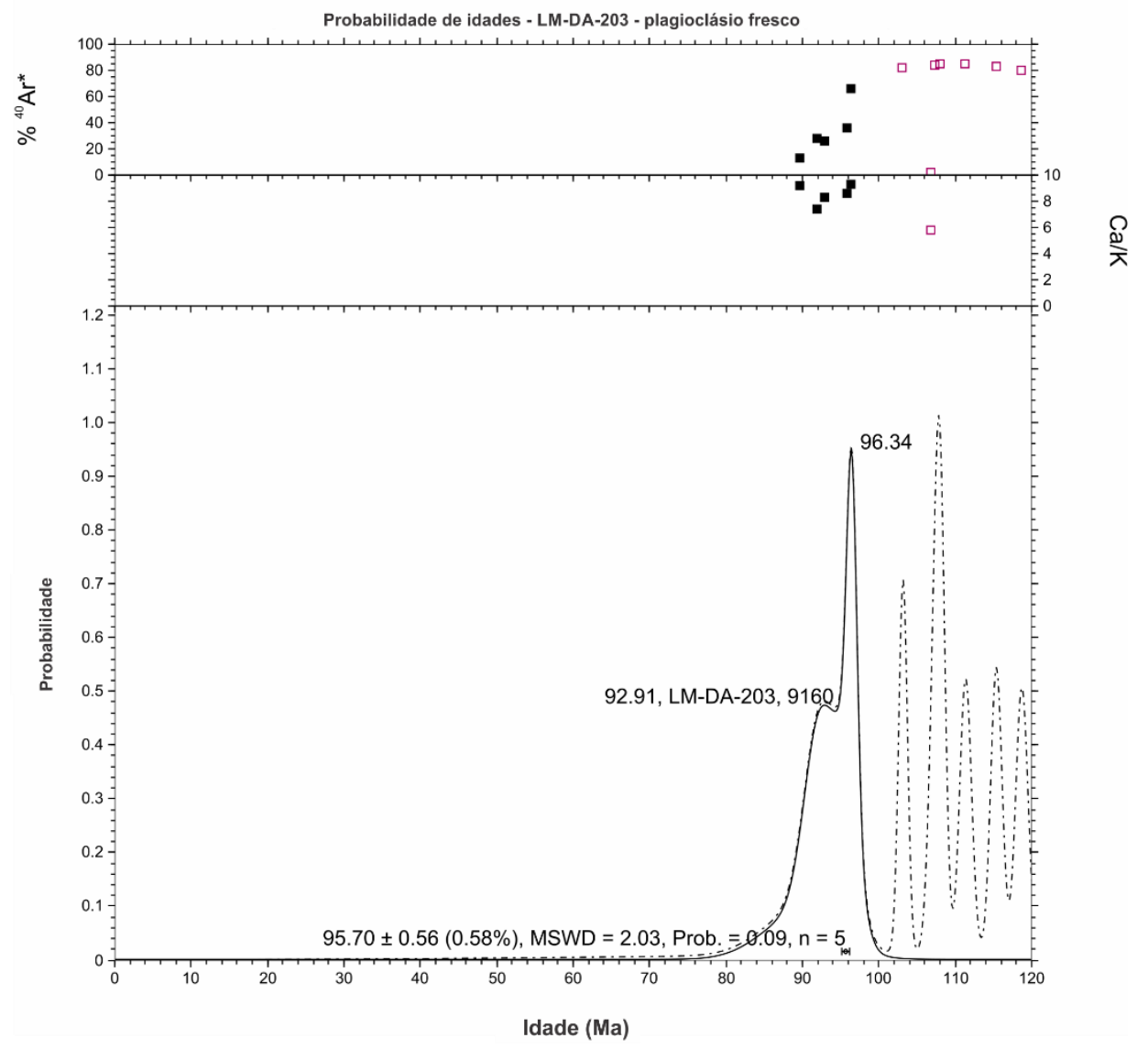

Figura 6.26: Diagrama de probabilidade de idade da alíquota de plagioclásio fresco da amostra LMDA-203. 


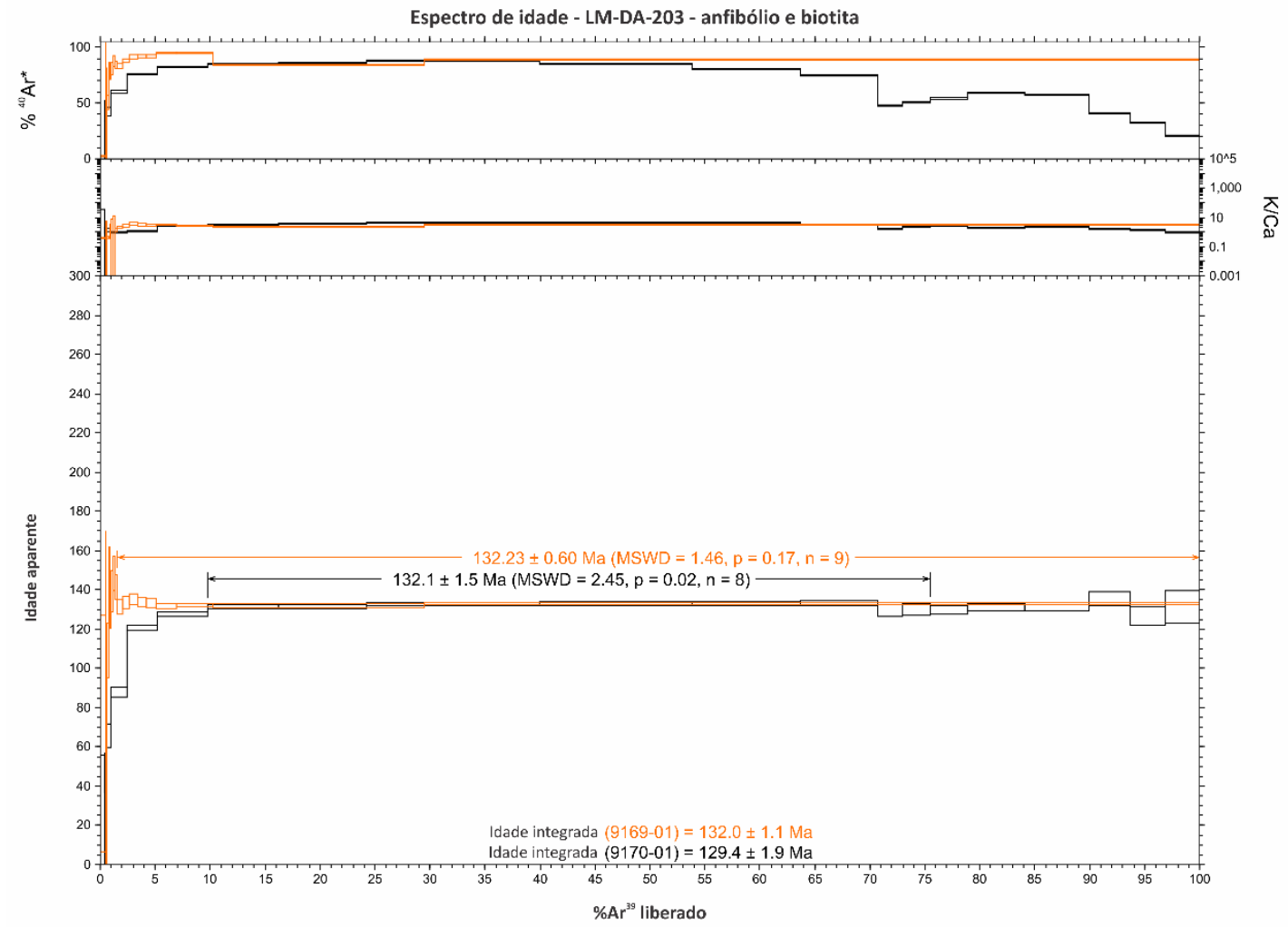

Figura 6.27: Espectro de idade da alíquota de anfibólio e biotita da amostra LM-DA-203.

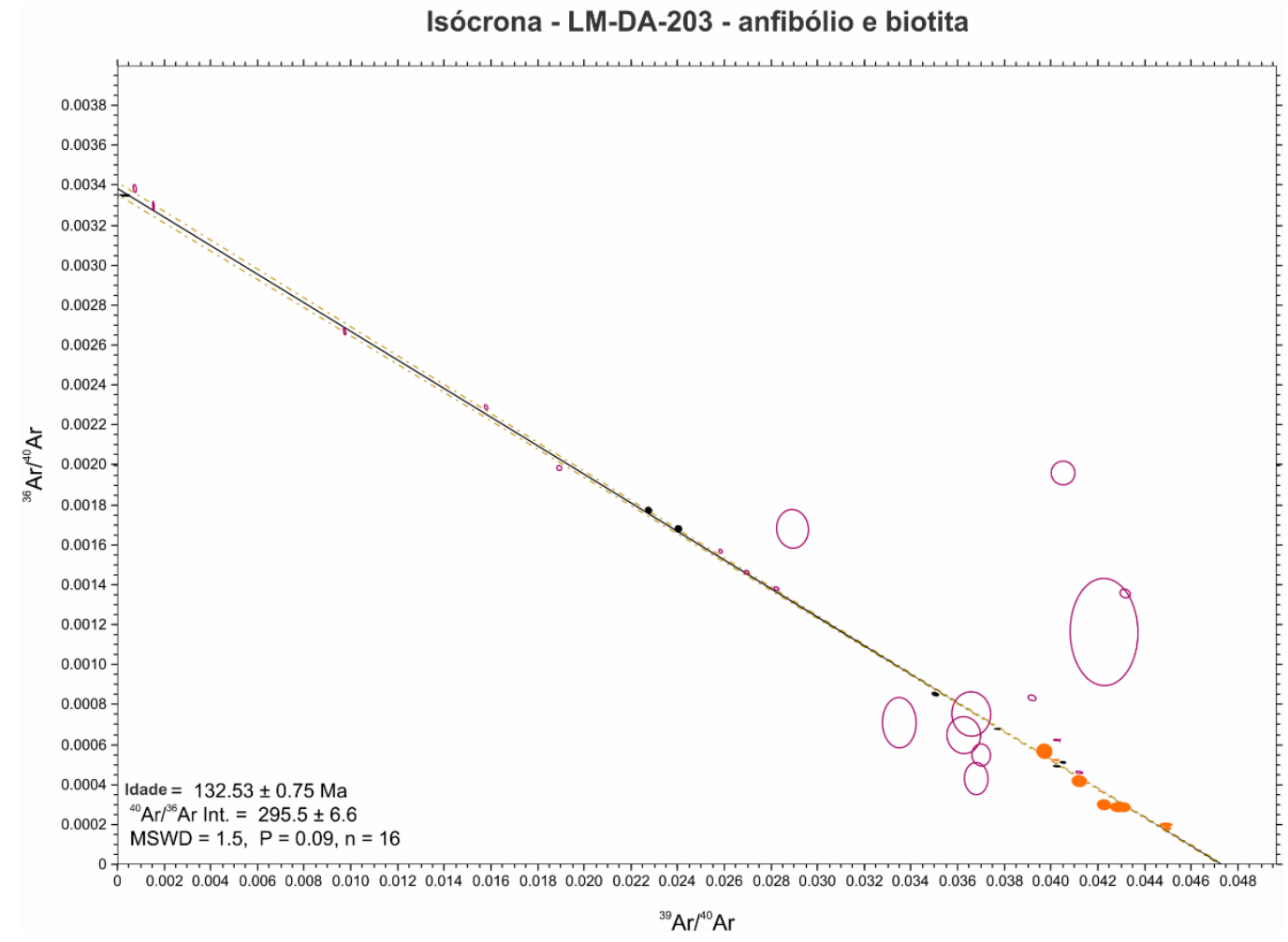

Figura 6.28: Isócrona das alíquotas de anfibólio e biotita da amostra LM-DA-203. 


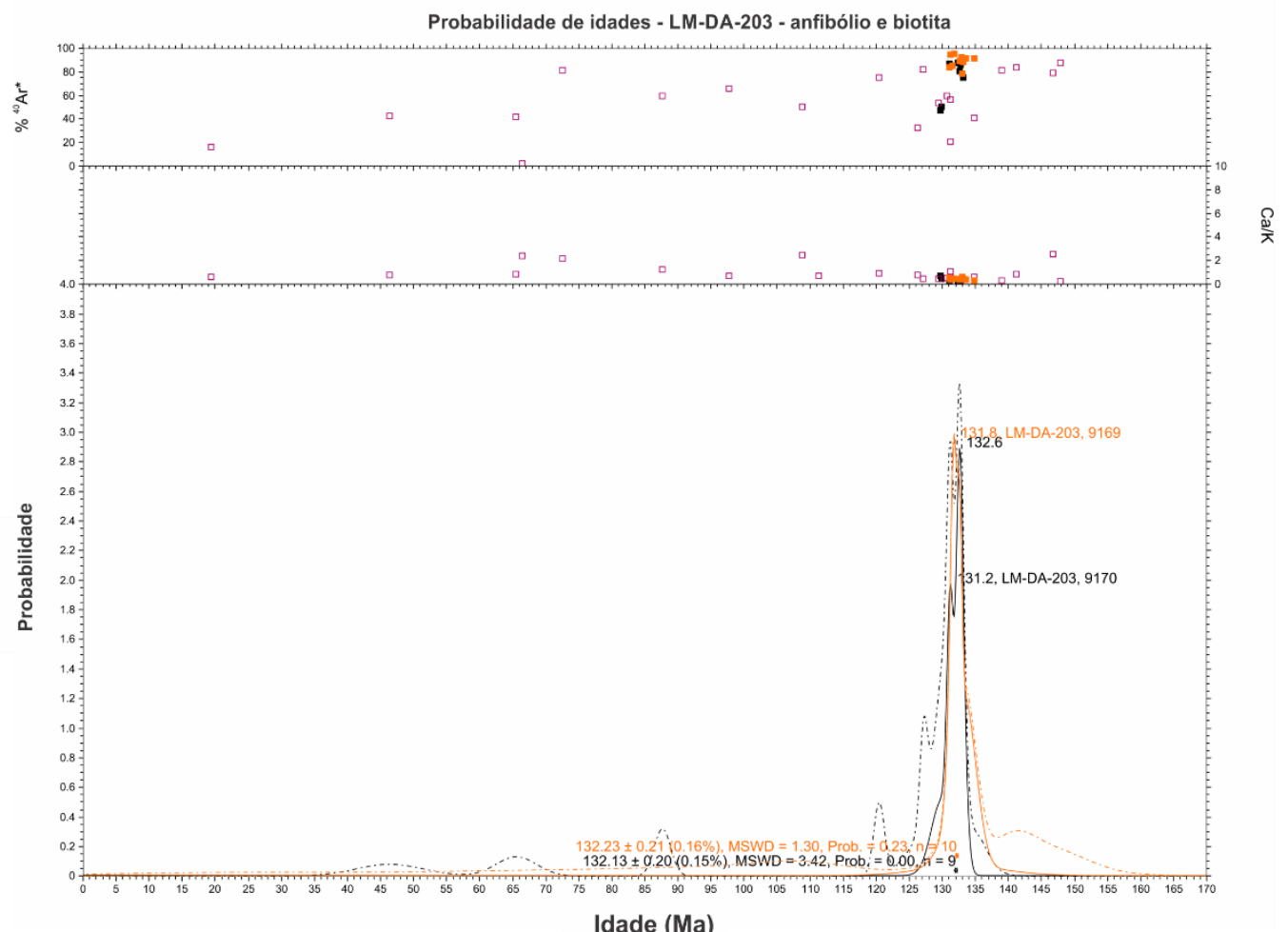

Figura 6.29: Diagrama de probabilidade de idade da alíquota de anfibólio e biotita da amostra LM-DA203. 
LM-DA-150 - Os resultados obtidos a partir das alíquotas encapsuladas atestam os fortes efeitos da sericitização na geocronologia ${ }^{40} \mathrm{Ar} /{ }^{39} \mathrm{Ar}$ em plagioclásios destas rochas intrusivas. A alíquota de plagioclásio sericitizado forneceu um platô estável em $108,50 \pm 0,46 \mathrm{Ma}$, que obedece a todos os critérios de qualidade propostos por Turner et al. (1994), sem sinais de excesso de Ar (figura 6.30), o que é reforçado pela isócrona

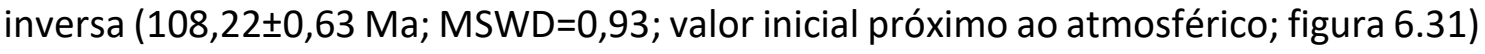

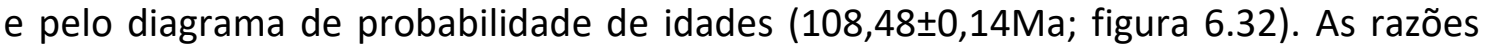
K/Ca da análise são compatíveis com a coexistência de fases de plagioclásio e sericita, e o primeiro estágio do espectro não indica efeitos de recuo significativos.

Entretanto, a alíquota de grãos de plagioclásio frescos forneceu resultados muito diferentes. O comportamento de seu espectro de idades não permitiu a definição de um platô e, assim como a isócrona, indica forte influência pelo excesso de Ar (figuras 6.33 e 6.34). O diagrama de probabilidade de idades é condizente com os menores valores de idades aparentes do espectro e indica idade máxima de cerca de $125 \mathrm{Ma}$ (figura 6.35). Novamente, as razões $\mathrm{K} / \mathrm{Ca}$, ainda que ligeiramente inferiores que aquelas da alíquota sericitizada, ainda refletem influência de ilita, sendo que o primeiro estágio da análise não indica influência significativa de recuo de Ar.

Um aspecto importante dos resultados obtidos é que um evento de cerca de 106$108 \mathrm{Ma}$ foi marcado pelas razões ${ }^{40} \mathrm{Ar} /{ }^{39} \mathrm{Ar}$ da sericita, o qual está presente tanto na amostra LM-DA-150, quanto na amostra LM-DA-203. Ambas pertencem ao grupo magmático $A$, mais primitivo. No entanto, as características texturais, zoneamento de cristais de plagioclásio e, consequentemente, histórias térmicas destas duas amostras são distintos (a textura porfirítica da amostra LM-DA-150 indica um resfriamento mais complexo). 


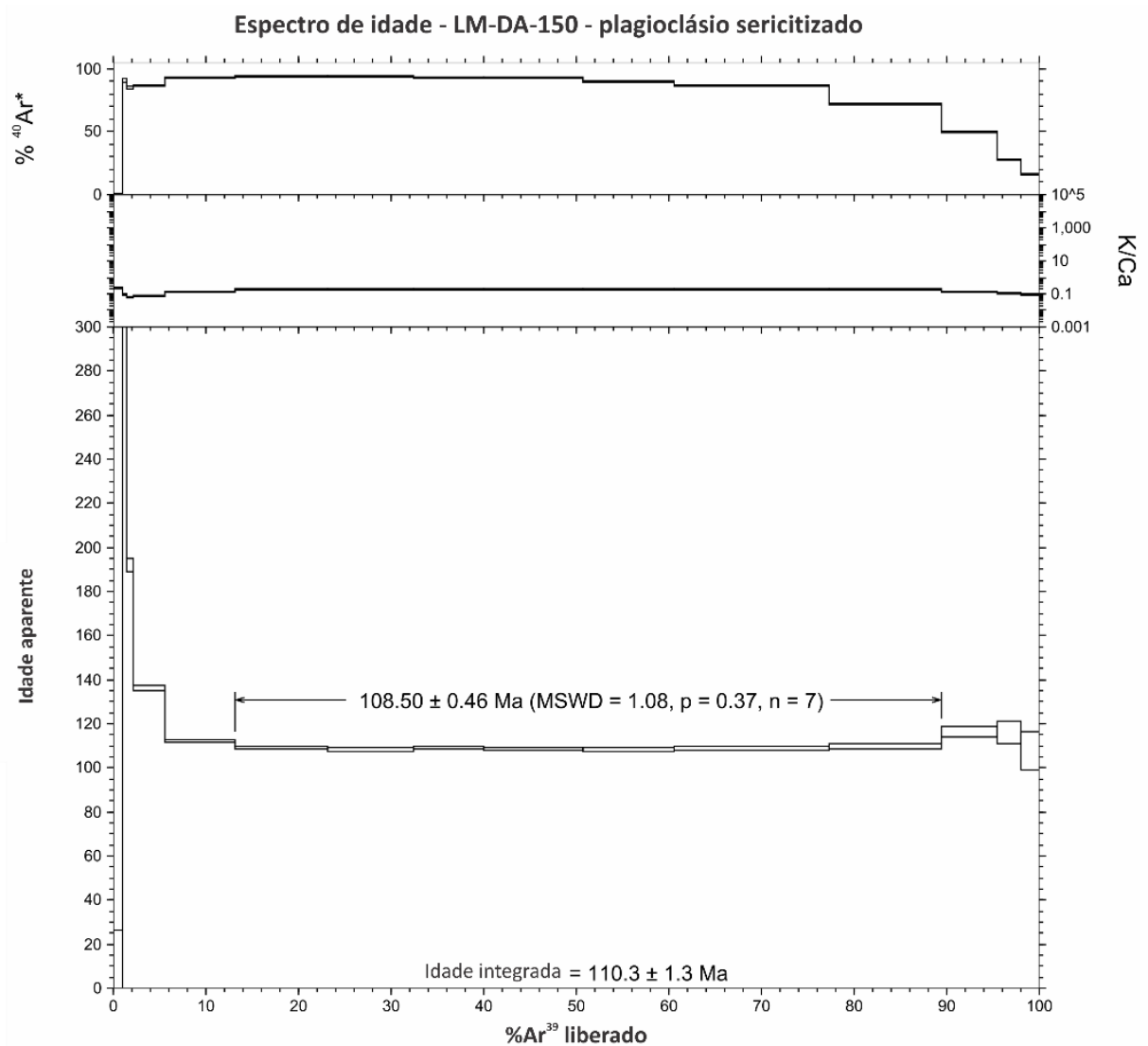

Figura 6.30: Espectro de idade da alíquota de plagioclásio sericitizado da amostra LM-DA-150.

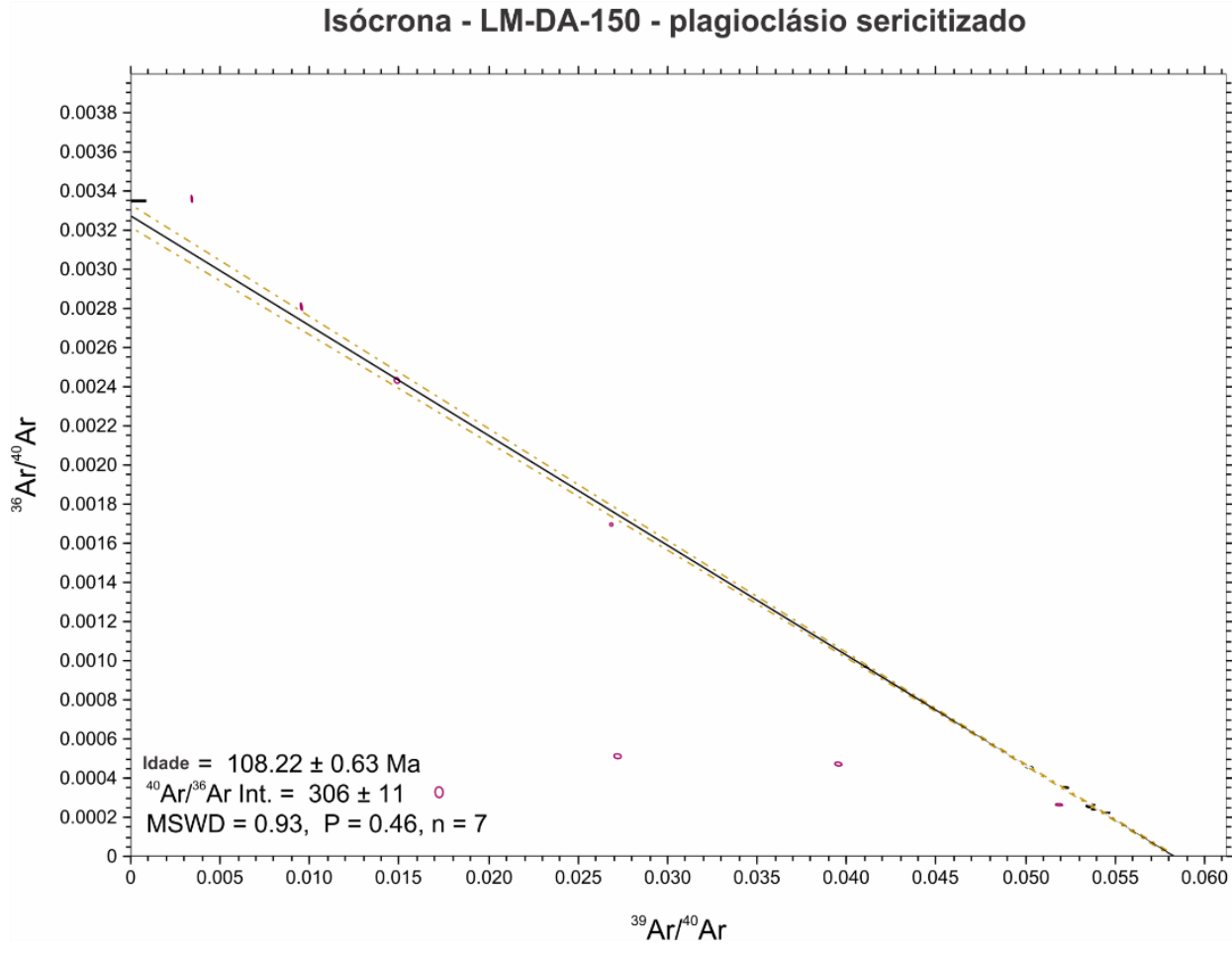

Figura 6.31: Isócrona da alíquota de plagioclásio sericitizado da amostra LM-DA-150. 


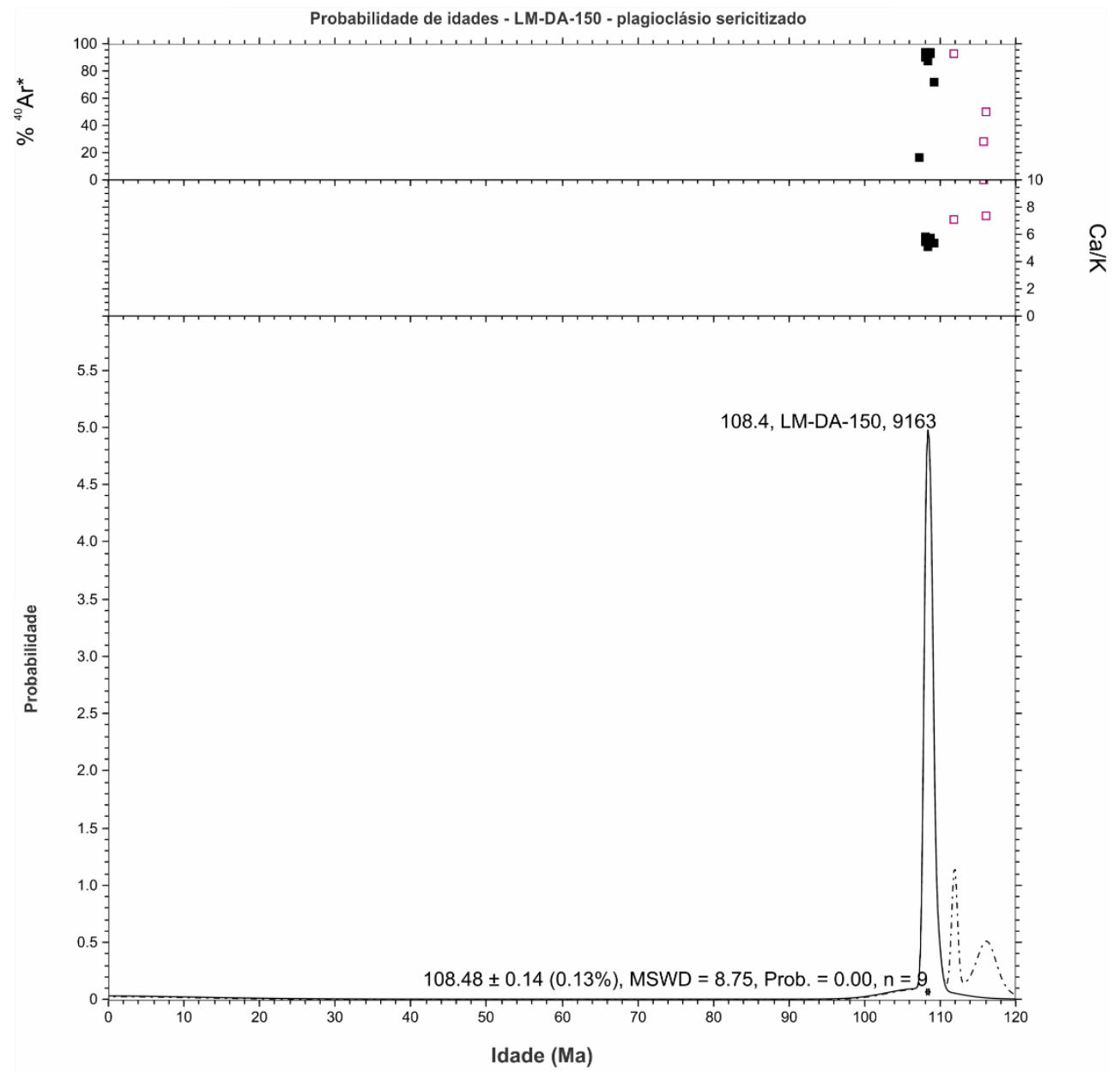

Figura 6.32: Diagrama de probabilidade de idade da alíquota de plagioclásio sericitizado da amostra LM-DA-150. 


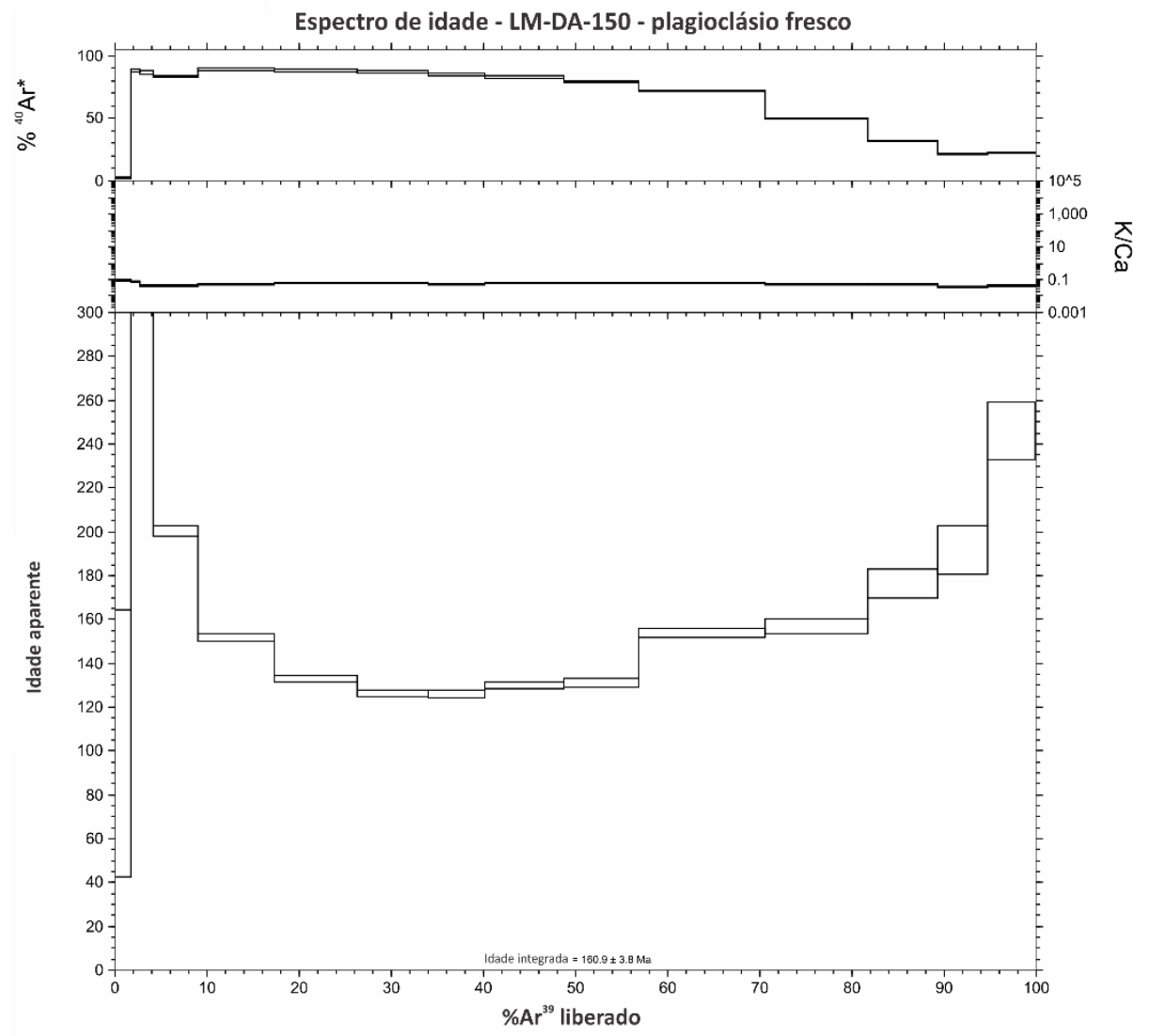

Figura 6.33: Espectro de idade da alíquota de plagioclásio fresco da amostra LM-DA-150.

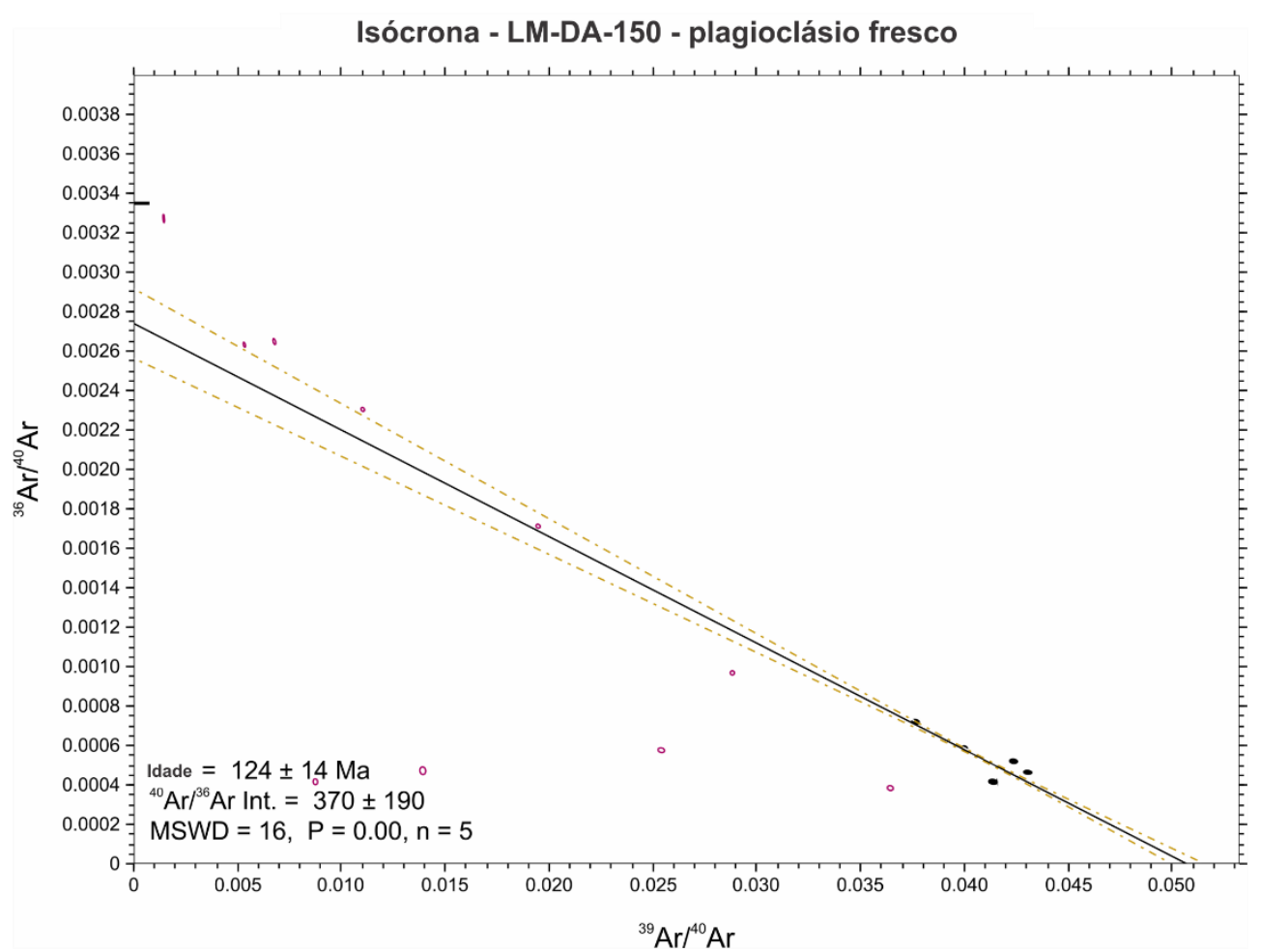

Figura 6.34: Isócrona da alíquota de plagioclásio fresco da amostra LM-DA-150. 


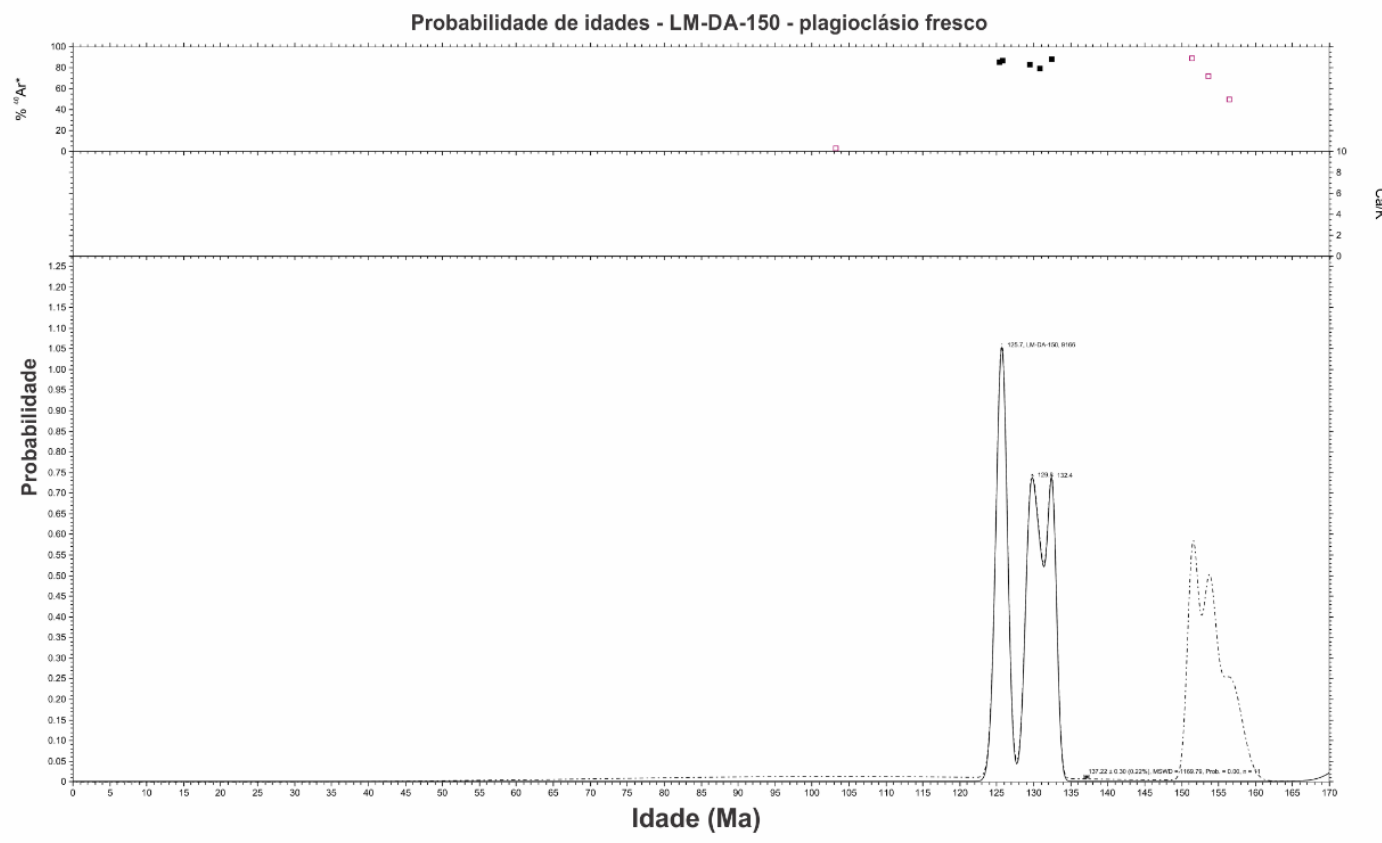

Figura 6.35: Diagrama de probabilidade de idade da alíquota de plagioclásio fresco da amostra LMDA-150. 
$L M-B Z-5 R$ - As análises de rocha total e de grãos de plagioclásio fresco desta amostra, pertencente ao grupo magmático $A$, apresentaram grande influência de excesso de $\operatorname{Ar}$ (figuras 6.36 e 6.37). O espectro de idades dos grãos de rocha total foi o mais afetado, apresentando também perturbações em altas temperaturas e idades máximas superiores a 160 Ma. Para o caso do plagioclásio, os estágios intermediários do espectro indicam idade máxima em torno de $140 \mathrm{Ma}$, com razões $\mathrm{K} / \mathrm{Ca}$ são compatíveis com os valores esperados para cristais não alterados. Também foram analisadas duas alíquotas de grãos de plagioclásio sericitizado, sendo que a primeira

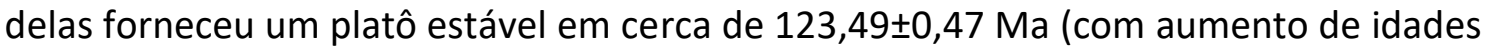
nos estágios finais, em função das inclusões de piroxênio; figura 6.38), enquanto a segunda forneceu um espectro totalmente perturbado por excesso de Ar (figura 6.39). Tal discrepância entre as alíquotas demonstra que as análises não atingiram representatividade suficiente da amostra, sendo assim inconclusivas. 


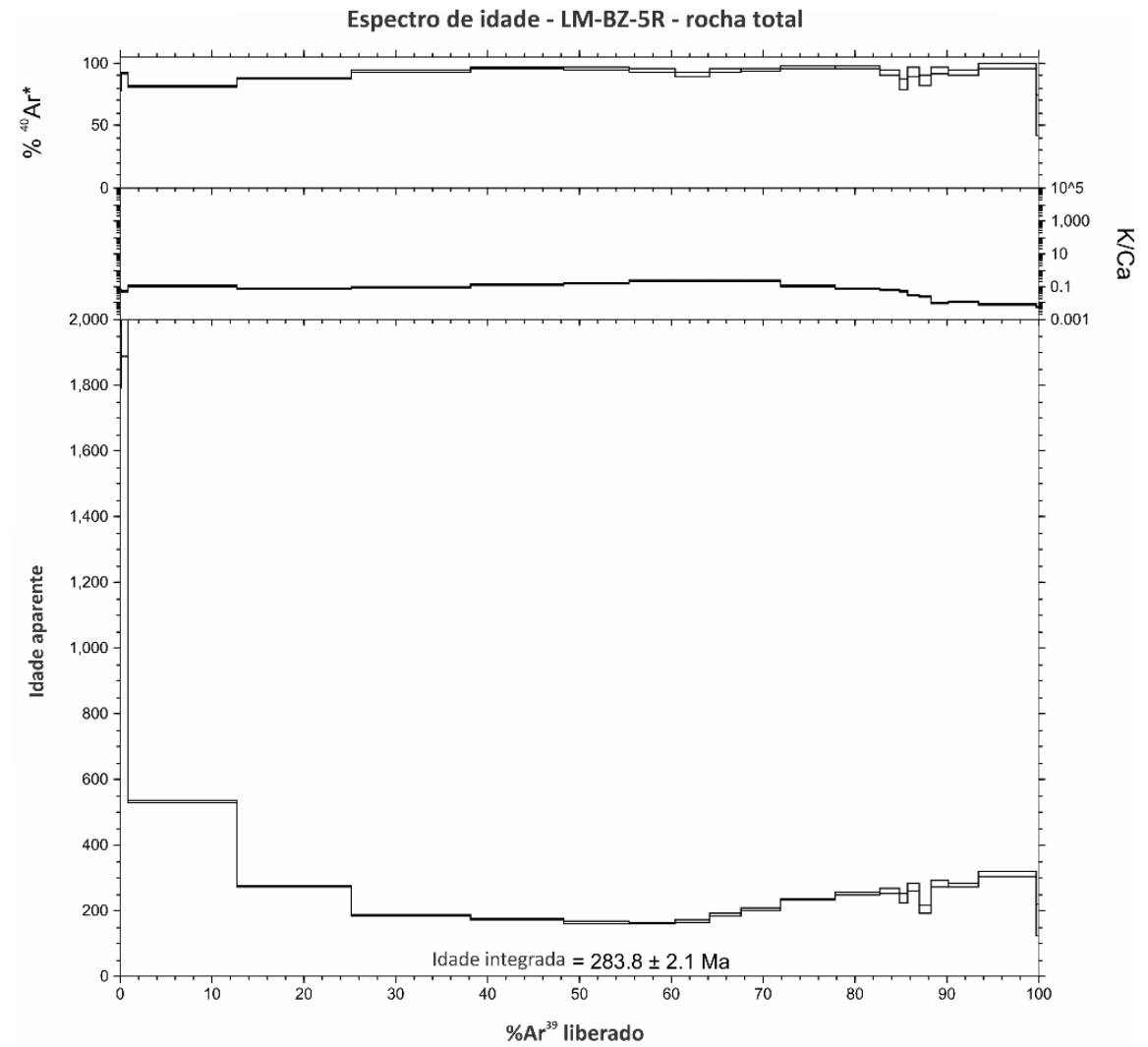

Figura 6.36: Espectro de idade de rocha total da amostra LM-BZ-5R.

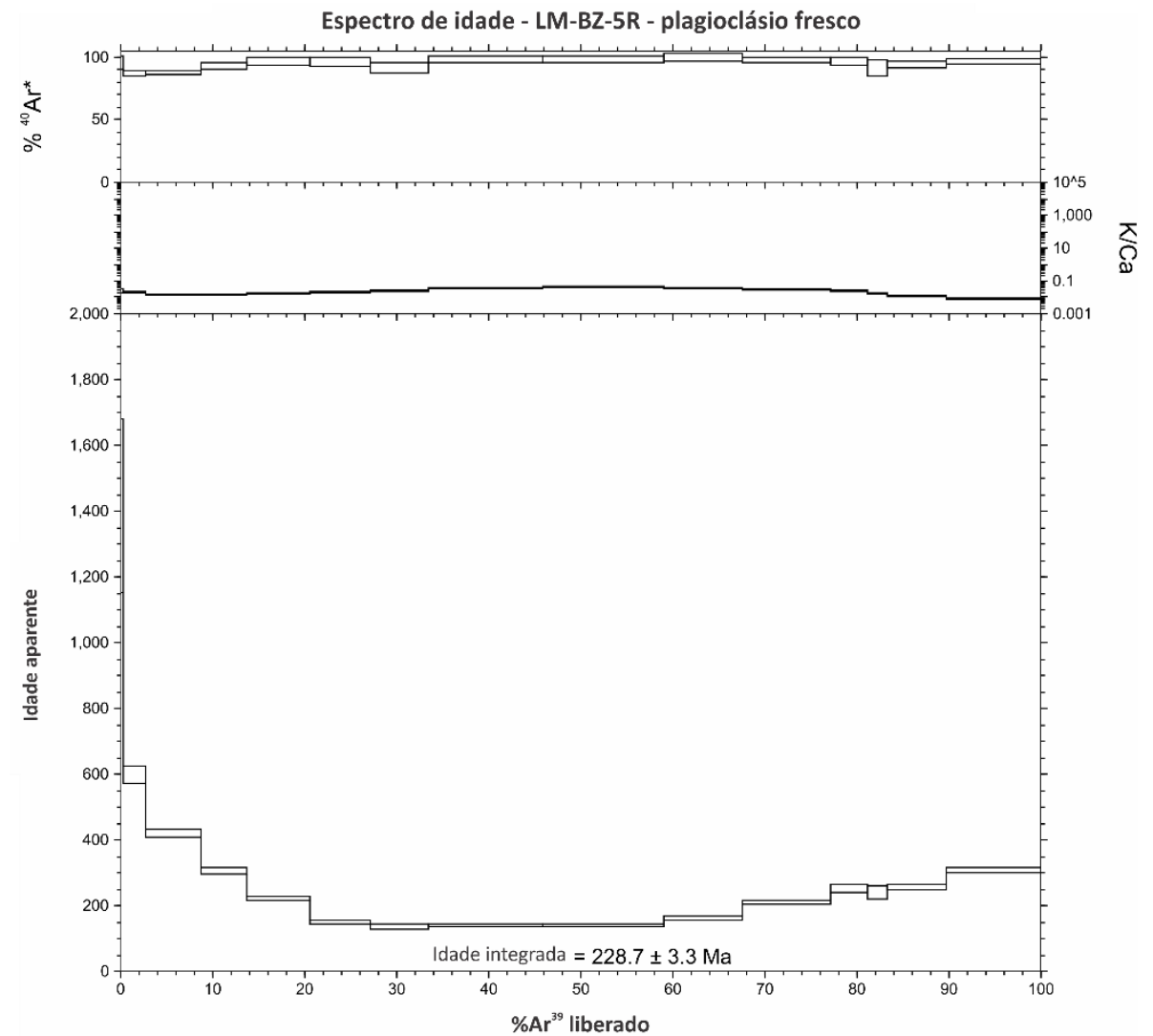

Figura 6.37: Espectro de idade de plagioclásio fresco da amostra LM-BZ-5R. 


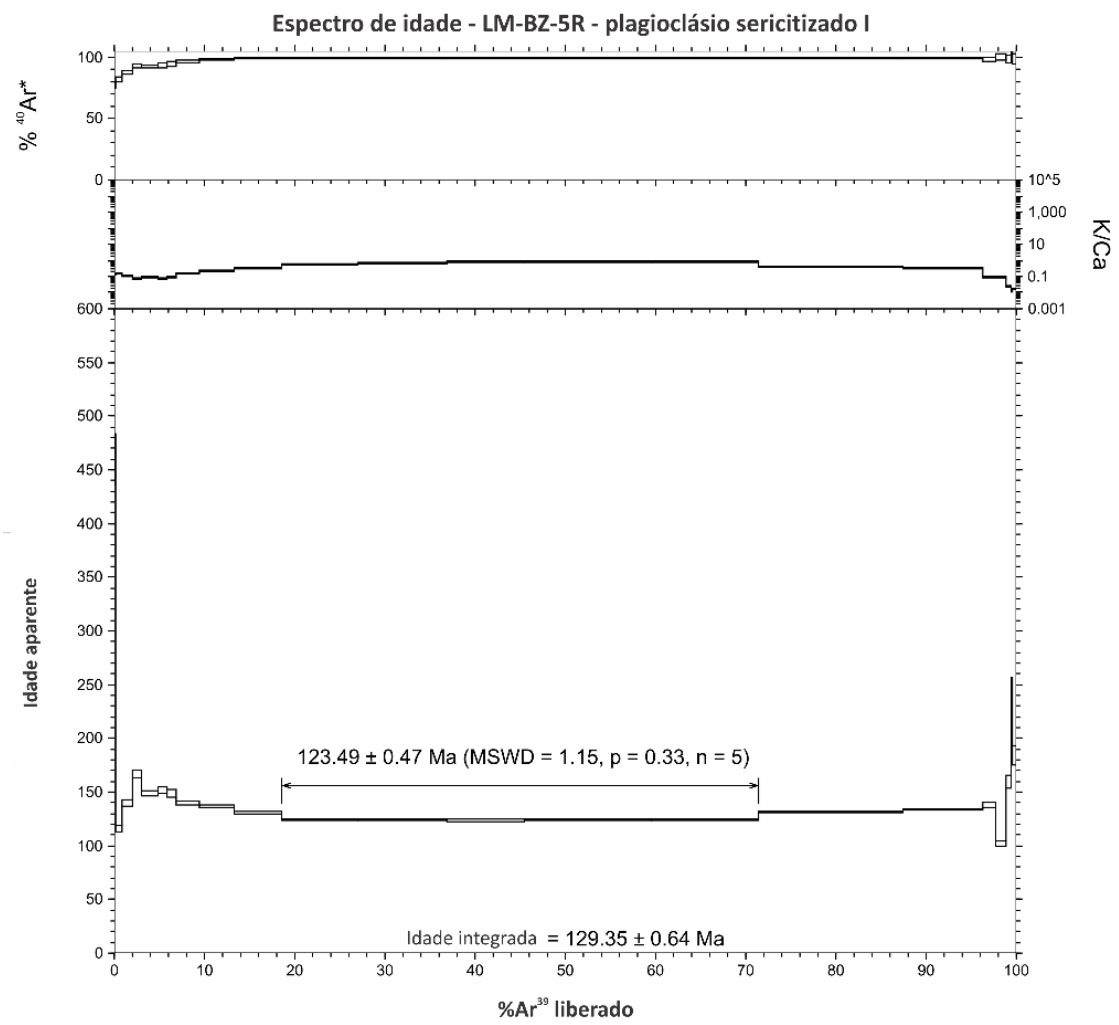

Figura 6.38: Espectro de idade de plagioclásio sericitizado da amostra LM-BZ-5R.

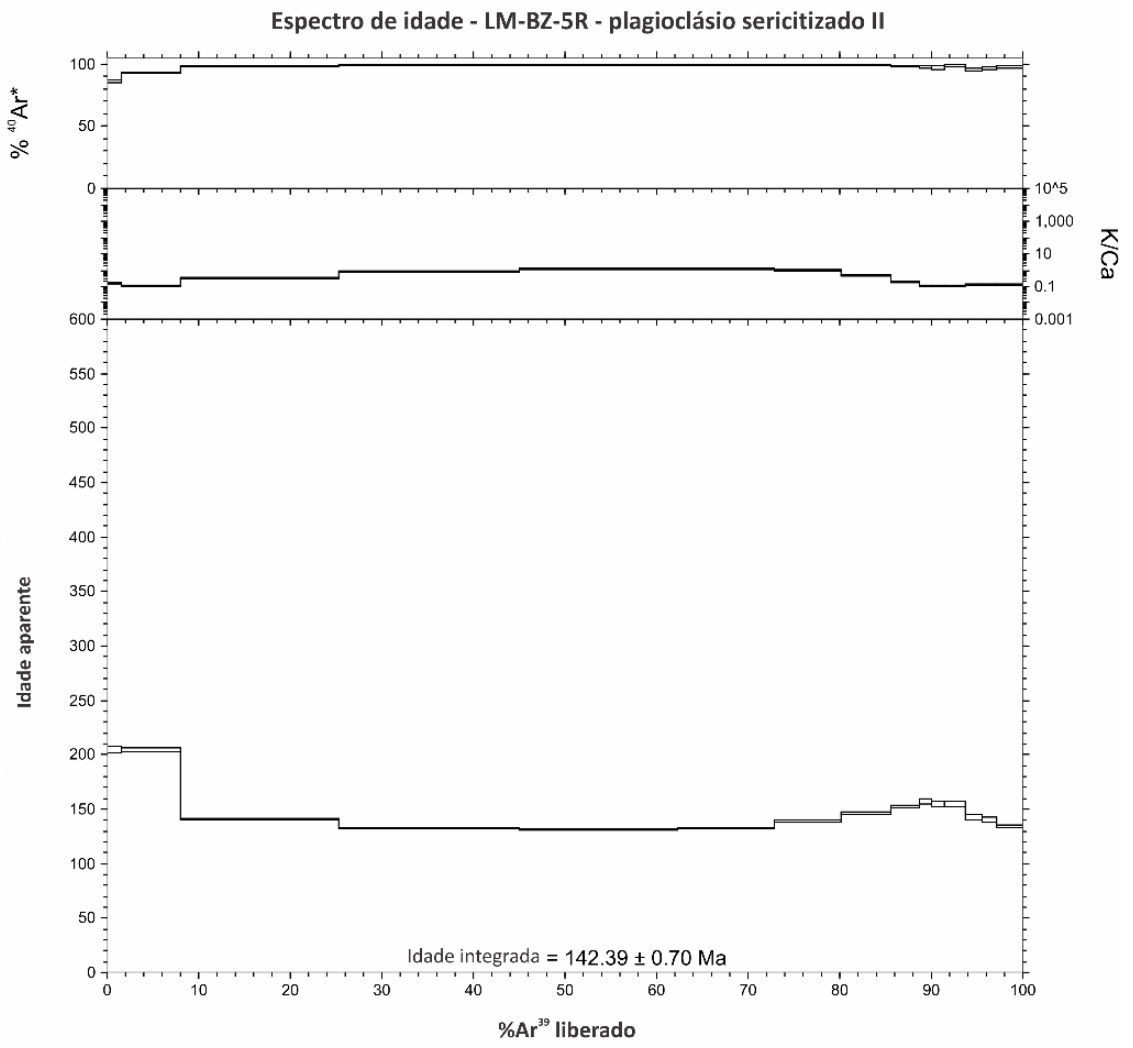

Figura 6.39: Espectro de idade de outra alíquota de plagioclásio sericitizado da amostra LM-BZ-5R. 


\subsubsection{GRUPO B}

LM-DA-161 - Uma das grandes dificuldades deste estudo foi a realização de datação em amostras do grupo magmático B, em função da maior presença de alterações em seus minerais e de sua textura afanítica. A amostra LM-DA-161 foi selecionada por ser uma exceção e não apresentar sericitização nos grãos de plagioclásio. Contudo, por conta de sua granulometria fina, apenas a análise em rocha total foi efetuada. Como esperado, o espectro de idades foi marcado por um forte comportamento do tipo "sela" (figura 6.40), com valores elevados de idade aparente nos estágios de alta temperatura do espectro resultantes da liberação de $\operatorname{Ar}$ dos piroxênios. $\mathrm{O}$ valor inicial ${ }^{36} \mathrm{Ar} /{ }^{40} \mathrm{Ar}$ da isócrona também indica forte influência de excesso de Ar (figura 6.41) e o diagrama de probabilidade de idades, assim como os estágios intermediários do espectro, indica idades entre 106 e $108 \mathrm{Ma}$ (figura 6.42). Uma vez que esta amostra não é afetada por sericitização, este valor pode ser interpretado como a idade máxima da intrusão. 


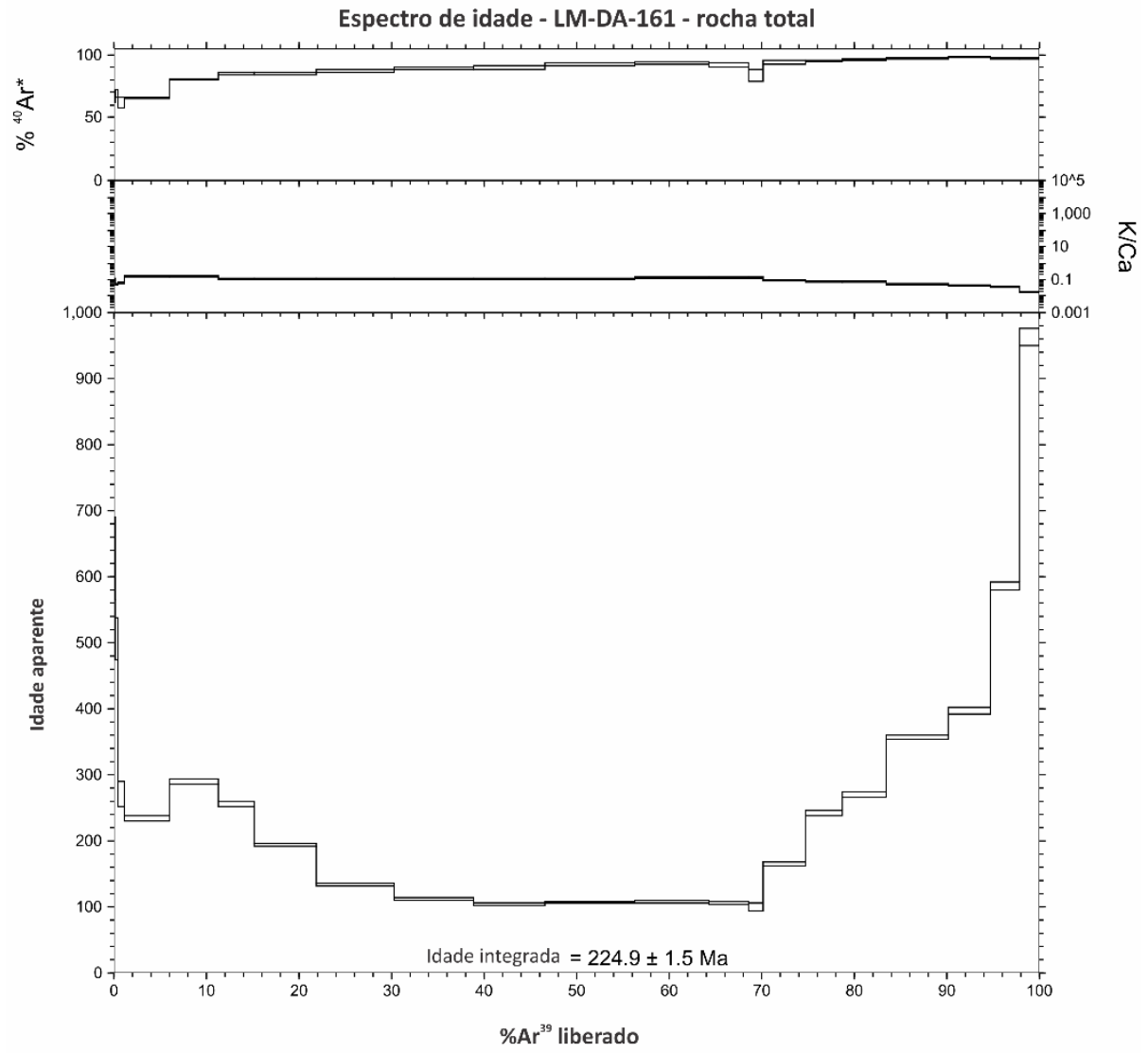

Figura 6.40: Espectro de idade de rocha total da amostra LM-DA-161.

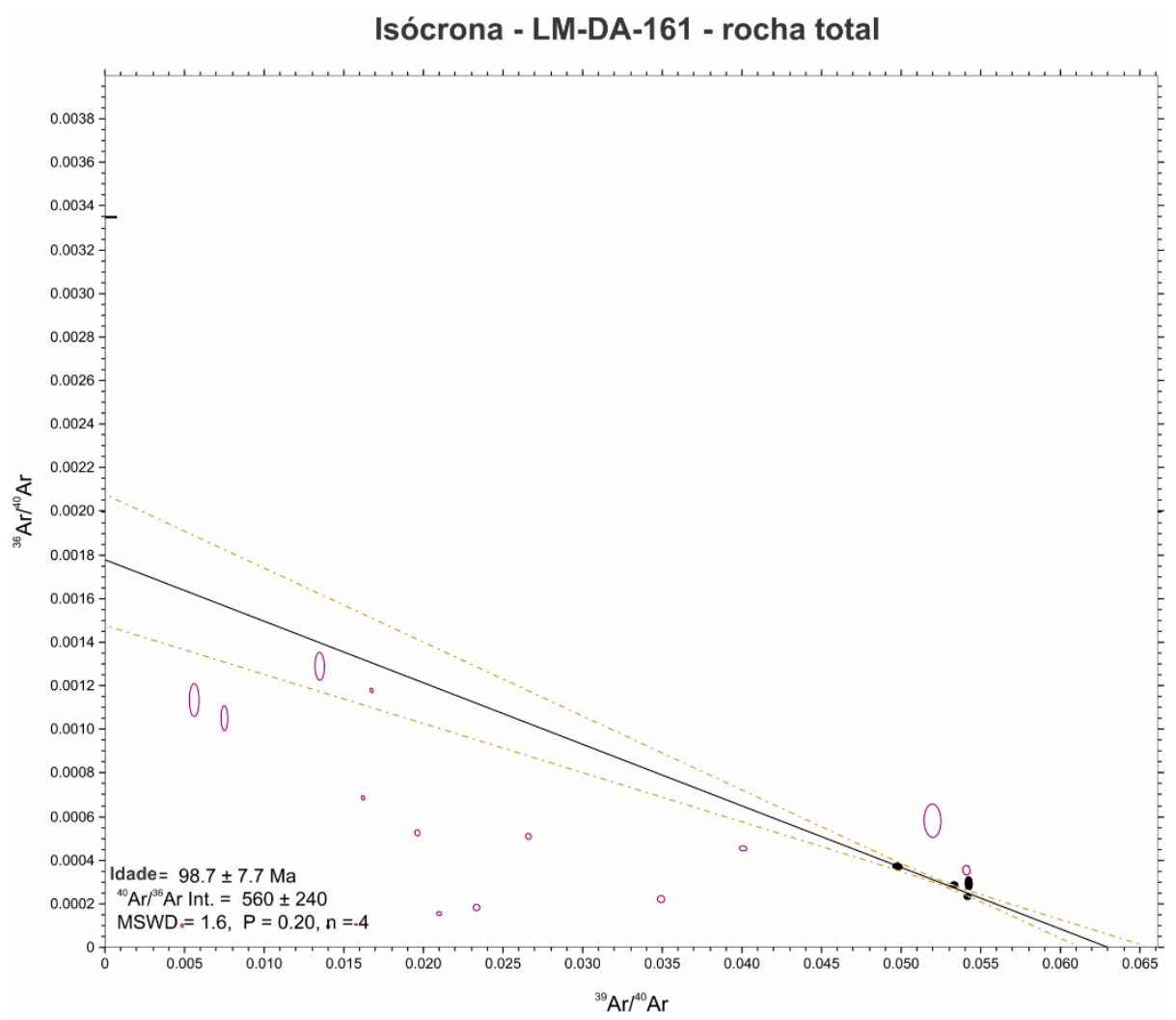

Figura 6.41: Isócrona de rocha total da amostra LM-DA-161. 


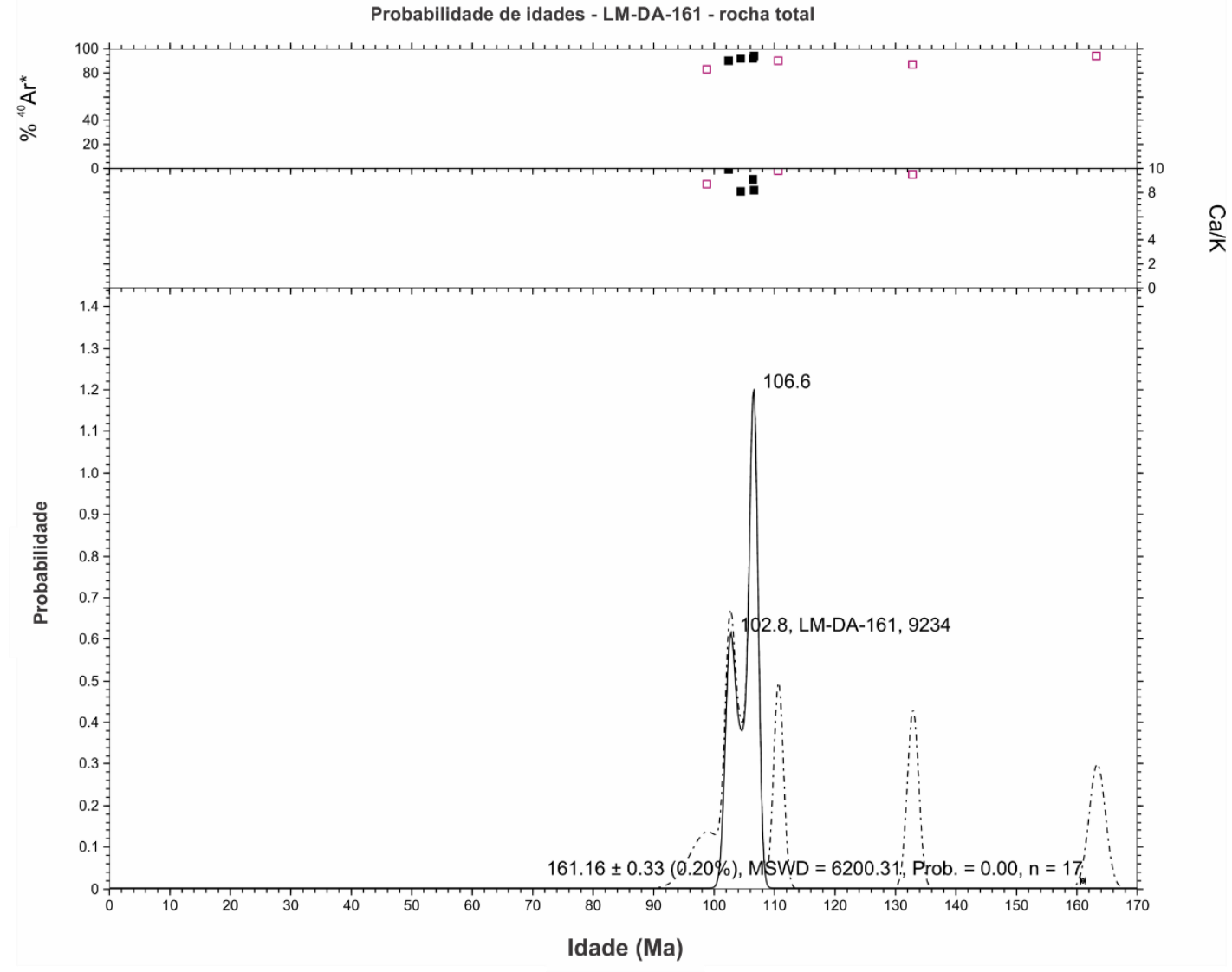

Figura 6.42: Diagrama de probabilidade de idade de rocha total da amostra LM-DA-161.

6.5. Resumo dos principais resultados geocronológicos e integração com as análises petrogenéticas

As análises geocronológicas descritas acima têm seus resultados resumidos na tabela 6.4 .

O grupo A, cujas características geoquímicas e isotópicas assemelham-se às dos diques primitivos de Horingbaai, apresentou platôs e isócronas confiáveis de $132,53 \pm 0,75 \mathrm{Ma}$, em alíquotas de anfibólios contendo uma pequena fração de biotita. Tal valor está de acordo com a faixa de idade inferida para os diques namibianos, de cerca de 131-133 Ma (Schmitt et al., 2000; Thompson, 2001) e indica que os diques primitivos da Região dos Lagos também estariam associados ao final do magmatismo Paraná-Etendeka, não apresentando participação significativa de processos de contaminação crustal, ao contrário de seus vizinhos imediatos, na região serrana do Rio de Janeiro (Marques, 2001; Corval, 2009). 
Tabela 6.4: Resumo dos resultados de geocronologia ${ }^{40} \mathrm{Ar} /{ }^{39} \mathrm{Ar}$ para cada uma das amostras analisadas.

\begin{tabular}{|c|c|c|c|c|c|}
\hline Grupo & Amostra & Fase mineral & Platô & Idade (Ma) & Excesso de Ar \\
\hline \multirow{8}{*}{ A } & \multirow{3}{*}{ LM-DA-203 } & $\begin{array}{l}\text { Plagioclásio sericitizado encapsulado } \\
\text { (regiões centrais) }\end{array}$ & Sim & $106,05 \pm 0,52 / 106,89 \pm 0,54$ & Não \\
\hline & & $\begin{array}{c}\text { Plagioclásio fresco encapsulado (bordas e } \\
\text { regiões centrais frescas) }\end{array}$ & Sim & $95,6 \pm 1,2$ & Não \\
\hline & & Anfibólio e biotita encapsulados & Sim & $132,23 \pm 0,6 / 132,1 \pm 1,6$ & Não \\
\hline & \multirow{2}{*}{ LM-DA-150 } & $\begin{array}{l}\text { Plagioclásio sericitizado encapsulado } \\
\text { (regiões centrais de fenocristais) }\end{array}$ & Sim & $108,50 \pm 0,46$ & Não \\
\hline & & $\begin{array}{c}\text { Plagioclásio fresco encapsulado (bordas } \\
\text { de fenocristais e cristais de matriz) }\end{array}$ & Não & Máxima: 125 & Sim \\
\hline & \multirow{3}{*}{ LM-BZ-5R } & $\begin{array}{l}\text { Plagioclásio sericitizado (região central de } \\
\text { fenocristal) }\end{array}$ & Sim (I) / Não (II) & 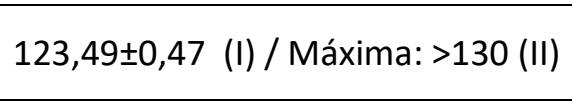 & Não (I) / Sim (II) \\
\hline & & Plagioclásio fresco (fenocristal fresco) & Não & Máxima: 140 & Sim \\
\hline & & Rocha total & Não & Máxima: > 160 & Sim \\
\hline B & LM-DA-161 & Rocha total & Não & Máxima: 106-108 & Sim \\
\hline
\end{tabular}


Uma vez que a amostra LM-DA-161, do grupo magmático $B$, não apresenta sericitização ou alterações portadoras de K, não se exclui a hipótese de que os grupos A e B não sejam contemporâneos. Essa ideia é reforçada pelos dados geoquímicos e isotópicos, que sustentam que suas fontes mantélicas são distintas. Contudo, conforme assinalado por Corval (2009), é possível que o espectro de idades obtido tenha sido perturbado por reaquecimentos regionais, o que teria causado difusão de Ar em suas fases menos estáveis.

No entanto, um aspecto interessante da idade máxima obtida para o grupo $B$ (amostra LM-DA-161) é que ela coincide com as idades de alteração obtidas nas alíquotas de plagioclásios sericitizados das amostras do grupo A, e também coincide com uma das fases de intrusão determinadas por meio de polos paleomagnéticos (Ernesto et al., 2014). Considerando que o grupo B de fato tenha sido intrudido na Região dos Lagos durante o Albiano, a amostragem e as análises realizadas neste trabalho puderam confirmar apenas dois dos três pulsos magmáticos determinados pelo estudo de Ernesto et al. (2014), ocorridos em cerca de 130 (grupo A) e 100 Ma (grupo B). As intrusões toleíticas de 50 Ma da região não puderam ser detectadas, seja por dificuldades em sua coleta (intemperização excessiva), seja pela grande proporção das alterações presentes em suas lâminas petrográficas. Permanece, assim, a questão acerca da ocorrência de tal pulso recente.

O valor máximo de cerca de 106-108 Ma obtido para o grupo B também se assemelha à idade marcada por outras metodologias para eventos do litoral da região Sudeste. Por meio de estudo termocronológico baseado em traços de fissão e (U-Th)/He em amostras da Serra do Mar, Serra da Mantiqueira e das Bacias Terciárias (Estados de São Paulo e Rio de Janeiro), e em posteriores processos de inversão e modelagens diretas, Cogné et al. (2012) puderam determinar uma fase de resfriamento pós-rifte no Sudeste, entre cerca de 100 e 70 Ma. Tal evento foi contemporâneo ao soerguimento da linha costeira (discutido por diversos autores, como Mohriak et al., 2008) e à reativação tectônica na Bacia de Santos (Cobbold et al., 2001).

Em termos regionais, Cogné et al. (2012) defendem que a litosfera do Sudeste poderia estar mais vulnerável a deformações neste período por conta de suas características estruturais e/ou por eventos de aquecimento. Em termos globais, os 
autores assinalam que, na mesma época, a taxa de expansão do Atlântico Sul sofria grande aumento e que a borda oeste da placa Sul-Americana iniciava sua colisão com a Placa de Nazca (geradora da Cadeia Andina), e defendem que as reativações tectônicas do Sudeste teriam relação com um fenômeno tectônico de grande escala.

Tendo em vista todos estes fatores e os resultados geocronológicos obtidos neste estudo, é possível supor que a intrusão dos diques do grupo B compõe o conjunto dos primeiros episódios de um processo de reativação tectônica que também incluiu soerguimento regional e aumento nas taxas de denudação - o que poderia explicar as diferenças de idade obtidas entre plagioclásios e anfibólios da amostra LM-DA-203, e as diferenças expressivas nas características das fontes envolvidas na gênese de A e B. Além disso, a movimentação majoritariamente compressiva promoveria, potencialmente, a mobilização de fluidos responsável pela sericitização das fases cálcicas dos plagioclásios de boa parte dos diques estudados. 


\section{CONSIDERAÇÕES FINAIS}

O estudo geoquímico e isotópico nos 22 diques coletados na Região dos Lagos (RJ) permitiu obter as seguintes informações:

- Os diques são quimicamente representados por basaltos toleíticos, basaltos andesíticos e basaltos transicionais, em sua maioria com teores de $\mathrm{TiO}_{2}$ menores que $2 \%$, e quatro deles com $\mathrm{TiO}_{2}<2,5 \%$. No diagrama AFM, as amostras apresentam comportamento típico de séries toleíticas em estágios iniciais de evolução. Os padrões de elementos maiores e menores indicam fracionamento de olivina, clinopiroxênio e plagioclásio.

- Dois grupos magmáticos são distinguíveis pelos padrões de elementos traço fortemente incompatíveis e por diagramas de razões de incompatíveis, correspondendo aos mesmos definidos por Bennio et al. (2003). Um deles, denominado de grupo A, apresenta-se mais primitivo e empobrecido em incompatíveis, enquanto o outro, grupo B, é mais evoluído e enriquecido nesses elementos. As tendências observadas no comportamento de $\mathrm{Nb}, \mathrm{Ta}, \mathrm{U}$, La e $\mathrm{Zr}$, em função de Th, sugerem que os grupos A e B não são cogenéticos, e que sofreram pouca influência de processos de assimilação crustal.

- O comportamento encontrado nos padrões de abundância dos grupos A e B normalizados pelo condrito $\mathrm{Cl}$ (McDonough \& Sun, 1995) apresenta maior fracionamento de ETR leves, que correspondem a estágios iniciais de fracionamento de olivina e piroxênios em séries toleíticas. Leves anomalias negativas de Eu são detectáveis apenas no grupo $B$, indicando também fracionamento de plagioclásio.

-A análise dos padrões de elementos traço incompatíveis normalizados pelo manto primitivo permitiu a detecção de algumas diferenças entre as amostras deste estudo e as reportadas por Bennio et al. (2003), especialmente em termos de concentrações de $\mathrm{Pb}$ e $\mathrm{P}$, menores no grupo $\mathrm{A}$, e de $\mathrm{Nb}$ para os dois grupos. Este último caso pode estar relacionado a diferenças de exatidão entre as metodologias de análise utilizadas (FRX e ICP-MS).

- Quando comparados com dados da literatura de derrames BTi da PMP, os diques do grupo A apresentam maiores semelhanças com os derrames do tipo Esmeralda, enquanto que o grupo B aparenta dispersar-se a partir dos derrames mais enriquecidos 
desse mesmo magma-tipo. Comparações com dados geoquímicos de outras intrusivas $B T i$ do ESM, disponíveis na literatura, mostram que o grupo " $A$ " definido por Corval (2009) espalha-se entre ambos os grupos do presente estudo. O grupo "B", definido pelo mesmo autor, assemelha-se notadamente aos derrames do tipo Gramado, assim como as intrusões serranas investigadas por Marques (2001).

- As análises isotópicas de $\mathrm{Sr}, \mathrm{Nd}$ e $\mathrm{Pb}$ realizadas em 9 amostras representativas resultaram em assinaturas ainda mais distintas entre os grupos A e B. O primeiro, menos radiogênico em $\mathrm{Sr}$, apresentou razões isotópicas de $\mathrm{Pb}$ maiores que o segundo. Em termos de razões ${ }^{143} \mathrm{Nd} /{ }^{144} \mathrm{Nd}_{132}$ e ${ }^{87} \mathrm{Sr} /{ }^{86} \mathrm{Sr}_{132}$, o grupo A apresenta comportamento similar aos derrames do tipo Esmeralda, enquanto as rochas de B não são semelhantes a nenhum grupo de basaltos BTi encontrados na PMP. Já as razões ${ }^{206} \mathrm{~Pb} /{ }^{204} \mathrm{~Pb}_{132} \mathrm{e}$ ${ }^{207} \mathrm{~Pb} /{ }^{204} \mathrm{~Pb}_{132}$ dos dois grupos são inferiores a qualquer das rochas vulcânicas citadas. $\mathrm{O}$ grupo A, mais primitivo, tem comportamento isotópico semelhante aos diques Horingbaai, da costa da Namíbia, ligados aos estágios finais de ruptura do Gondwana.

- O comportamento das razões isotópicas de $\mathrm{Pb}$ de ambos os grupos é incompatível com processos de assimilação de material crustal; esta característica foi verificada por meio de testes com curvas de processos AFC. Para isso, foram utilizadas a média dos diques Horingbaai (Namíbia) mais primitivos e várias componentes de crosta continental, de modo que nenhuma das curvas ajustou-se satisfatoriamente aos dados de todos os sistemas isotópicos, tanto no sentido de definir um caminho evolutivo entre $A$ e $B$, quanto para definir um caminho evolutivo para $A$, isoladamente. Testes com curvas de mistura simples entre diferentes reservatórios mantélicos (DMM e EMI) também não obtiveram sucesso. Tal dificuldade pode estar associada à grande heterogeneidade do manto litosférico sob o Domínio Cabo Frio, ligada aos longos processos de subducção durante a amalgamação do Gondwana.

- Diferenças nas razões La/NbPM de cada um dos grupos e o comportamento de elementos traço incompatíveis em função das razões ${ }^{87} \mathrm{Sr} /{ }^{86} \mathrm{Sr}_{132}$ corroboram a hipótese da ausência de participação significativa de crosta continental no processo evolutivo dos grupos A e B, e sugerem que ambos são oriundos de fontes mantélicas distintas.

- Análises em microscópio ótico e MEV efetuadas nos diques indicam que a mineralogia essencial é composta de plagioclásio, piroxênio e magnetita, além de olivina, anfibólio, biotita e apatita (acessórios). Ocorrências de alterações como 
cloritização em piroxênios, bem como a presença de pirita e calcopirita em zonas de contato entre cristais de piroxênio e plagioclásio, e sericitização em zonas centrais dos cristais de plagioclásio variam muito de acordo com a amostra analisada, assim como a textura e granulometria, que não seguem padrões definidos dentro dos grupos A e B. Os grãos de plagioclásio são afetados por grande quantidade de inclusões de piroxênios, apatitas e, mais raramente, magnetita, pirita e calcopirita. O padrão de zoneamento do plagioclásio também é amplamente variável de acordo com a amostra; quando detectável, apresenta geralmente uma zona central mais anortítica e bordas mais albíticas.

- As análises geocronológicas encontram-se resumidas na tabela 6.4. Para amostras do grupo $A$, os resultados obtidos foram de 106,05 $\pm 0,52,106,89 \pm 0,54$ e 108,5 $\pm 0,46$ Ma para as alíquotas de grãos de plagioclásio sericitizados. Grãos de

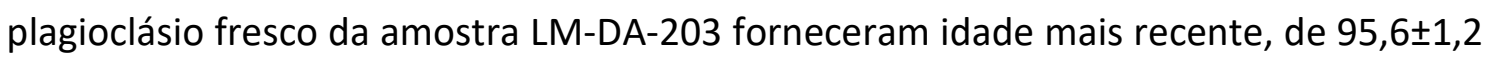
Ma, provavelmente influenciada por eventual sericitização e talvez por albitização mais recente nas bordas dos grãos. As idades máximas obtidas para os plagioclásios frescos das amostras LM-DA-150 e LM-BZ-5R são mais antigas que aquelas medidas em grãos alterados, e evidenciam a grande influência da sericitização nos espectros de idade, a qual pode gerar platôs muito estáveis na idade de alteração. A forte presença de excesso de Ar nas análises também evidencia a grande influência das inclusões presentes no plagioclásio.

- O mesmo efeito ficou ainda mais claro com os resultados das alíquotas de

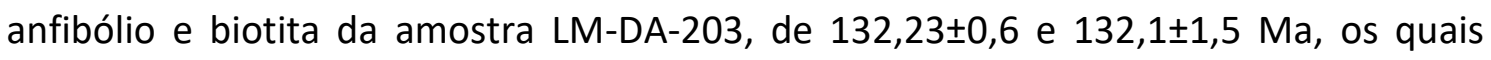
devem corresponder à idade de intrusão do corpo, estando também de acordo com a idade inferida para os diques primitivos de Horingbaai (Schmitt et al., 2000; Thompson, 2001). Estes valores reforçam a associação dos diques do grupo $A$ aos estágios finais de formação da PMP. Tais resultados diferem consideravelmente dos espectros obtidos em plagioclásio para a mesma amostra, mineral muito mais suscetível a efeitos de resfriamento prolongado e/ou reaquecimentos regionais por conta de sua baixa temperatura de fechamento para difusão de Ar. Em suma, as análises obtidas nas diferentes frações analisadas de plagioclásio sugerem que boa parte dos dados geocronológicos da literatura para os diques do ESM por ${ }^{40} \mathrm{Ar} /{ }^{39} \mathrm{Ar}$ obtidos a partir desse 
mineral podem ter sido afetados por esses processos de alteração e/ou pela presença de inclusões e precisam ser cuidadosamente reavaliados.

- A datação de amostras do grupo B apresentou dificuldades por conta da maior presença de alterações e de sua granulometria mais fina. A amostra LM-DA-161, livre de sericitização, apresentou idades máximas para um grão de rocha total entre 106-108 Ma. Apesar da baixa qualidade do espectro obtido, tal resultado sugere que os grupos A e B podem não ser contemporâneos, o que é reforçado pelos resultados geoquímicos, que sugerem fontes mantélicas distintas.

- As datações realizadas neste trabalho coincidiram com dois dos três pulsos magmáticos determinados por paleomagnetismo por Ernesto et al. (2014), ocorridos em cerca de 130 (grupo A) e 100 Ma (grupo B). As intrusões toleíticas de 50 Ma não puderam ser analisadas via ${ }^{40} \mathrm{Ar} /{ }^{39} \mathrm{~A}$ por excesso de intemperismo e/ou alterações presentes em seus minerais. Permanece, assim, a questão acerca da ocorrência de tal pulso.

- Ainda que o comportamento do espectro de idades possa ter sido afetado por reaquecimentos regionais, conforme proposto por Corval (2009), a idade de 106-108 Ma da amostra do grupo $B$ corresponde àquela obtida nos grãos de plagioclásio alterados do grupo A, e também ao evento de soerguimento da linha de costa do Sudeste e posterior resfriamento proposto por Cogné et al. (2012), eventos ligados a processos tectônicos de grande escala. Tal coincidência sugere que os diques do grupo B e a alteração por fluidos da maior parte das intrusões do Sudeste podem estar relacionadas aos primeiros episódios de um grande processo de reativação tectônica, anterior às intrusões alcalinas do Paleogeno, e que envolveu fontes mantélicas distintas daquelas atuantes na abertura do Atlântico Sul. 


\section{REFERÊNCIAS}

Alexander, E.C., Jr., \& Davis, P.K. (1974). 40Ar-39Ar ages and trace element contents of Apollo 14 breccias; an interlaboratorycross-calibrationof40Ar-39Ar standards. Geochimica et Cosmochimica Acta, 38: 911-928.

Almeida, F. F. M.; Hasui, Y.; Brito-Neves, B. B.; Fuck, R. A. (1981). Brazilian structural provinces: an introduction. Earth-Science Reviews, 17: 1-29.

Almeida, F.F.M. (1986). Distribuição regional e relações tectônicas do magmatismo póspaleozóico no Brasil. Revista Brasileira de Geociências, 16(4): 325-349.

Almeida, J.; Dios, F.; Mohriak, W.U.; Valeriano, C.D.M.; Heilbron, M.; Eirado, L.G.; Tomazzoli, E. (2013). Pre-rift tectonic scenario of the Eo-Cretaceous Gondwana break-up along SE Brazil-SW Africa: insights from tholeiitic mafic dyke swarms. Geological Society of London, Special Publications, 369: 11-40.

Al-Merey, R.; Karajou, J.; Issa, H. (2005). X-ray fluorescence analysis of geological samples: exploring the effect of sample thickness on the accuracy of results. Applied Radiation and Isotopes, 62: 501-508.

Assumpção, M; Marza, V.; Barros, L.; Chimpliganond, C.; Soares, J.E.; Carvalho, J.; Caixeta, D.; Amorin, A.; Cabral, E. (2002). Reservoir induced seismicity in Brazil. Pure applied Geophysics, 159: 597-617.

Barreto, C.J.S.; Lafon, J.M.; Lima, E.F.; Sommer, C.A. (2016). Geochemical and Sr-Nd-Pb isotopic insight into the low-Ti basalts from southern Paraná Igneous Province, Brazil: the role of crustal contamination. International Geology Review, 58: 1324-1349.

Bennio, L.; Brotzu, P.; D'Antonio, M.; Feraud, G.; Gomes, C.B.; Marzoli, A.; Melluso L.; Morbidelli, L.; Morra, V.; Rapaille, C.; Ruberti, E. (2003). The tholeiitic dyke swarm of the Arraial do Cabo peninsula (SE Brazil): 39Ar/40Ar ages, petrogenesis, and regional significance. Journal of South American Earth Sciences, 16(2): 163-176.

Brito-Neves, B.B.; Campos-Neto, M.D.; Fuck, R.A. (1999). From Rodinia to Western Gondwana: An approach to the Brasiliano-Pan-African Cycle and orogenic collage. Episodes, 22 (3): 155-166.

Campos Neto, M.C. (2000). Orogenic Systems from Southwestern-Gondwana: an approach to Brasiliano-Pan African Cycle and orogenic collage in southeastern-Brazil. In: Cordani, U.G.; Milani, E.J.; Thomaz-Filho, A.; Campos, D.A. Tectonic Evolution of South America. Proceedings of the 31st International Geological Congress, Rio de Janeiro: 335-365. 
Carvas, K.Z. (2014). Determinação de razões isotópicas de $\mathrm{Sr}$, $\mathrm{Nd}$ e $\mathrm{Pb}$ de diques do Cretáceo Inferior do Enxame da Serra do Mar (SP-RJ). Trabalho de Conclusão de Curso, Universidade de São Paulo.

Chang, H.K.; Kowsman, R.O.; Figueiredo, A.M.; Bender A.A. (1992). Tectonics and stratigraphy of the East Brazil Rift System - An overview. Tectonophysics, 213:97-138.

Cobbold, P. R.; Meisling, K.E.; Mount, V.S. (2001). Reactivation of an obliquely rifted margin, Campos and Santos Basins, southeastern Brazil, AAPG Bulletin, 85: 1925-1944.

Cobbold, P. R.; Chiossi, D.; Green, P.F.; Jaspen, P.; Bonow, J. (2010), Compressional reactivation of the Atlantic Margin of Brazil: Structural styles and consequences for hydrocarbon exploration. Search Discovery, 30114.

Cogné, N.; Gallagher, K.; Cobbold, P.R.; Riccomini, C.; Gautheron, C. (2012). Post break-up tectonics in Southeast Brazil from thermochronological data and combined inverse-forward thermal history modeling. Journal of Geophysical Research, 117: B11413.

Comin-Chiaramonti, P.; Gomes, C.B.; Piccirillo, E.M.; Rivalenti, G. (1983). High $\mathrm{TiO}_{2}$ dikes in the coastline of São Paulo and Rio de Janeiro States. Neues Jahrbuch Mineralogie Abhandlungen, 146(2):133-150.

Comin-Chiaramont, P.; Cundari, A.; Piccirillo, E.M.; Gomes, C.B.; Castorina, F.; Censi, P.; De Min, A.; Marzoli, A.; Speziale, S.; Velázquez, V.F. (1997). Potassic and sodic igneous rocks from Eastern Paraguay: their origin from the lithospheric mantle and genetic relationships with associated Paraná flood tholeiites. Journal of Petrology, 38(4):495-528.

Condomines, M.; Morand, P.; Allègre, C.J. (1981). 230Th-238U radioactive disequilibria in tholeiites from the FAMOUS zones (Mid-Atlantic Ridge, $36^{\circ} 50^{\prime} \mathrm{N}$ ): Th and $\mathrm{Sr}$ isotopic geochemistry. Earth and Planetary Science Letters, 55:247-256.

Corval, A.; Valente, S.C.; Duarte, B.P.; Famelli, N.; Zanon, M. (2008). Dados petrológicos dos diabásios dos setores centro-norte e nordeste do Enxame de Diques da Serra do Mar. Geochimica Brasiliensis, 22 (3): 159-177.

Corval, A. (2009). Petrogênese e Contexto Geodinâmico das Suítes Basálticas Toleíticas (de alto-TiO2 e baixo-TiO2) do Cretáceo Inferior da Porção Centro-oriental do Enxame de Diques da Serra do Mar. Tese de Doutorado, Universidade do Estado do Rio de Janeiro, Rio de Janeiro.

Coutinho, J. M. V. (2008). Dyke Swarms of the Paraná Triple Junction, Southern Brazil. Revista do Instituto de Geociências, Universidade de São Paulo, 8: 29-52.

Corti, G.; Bonini, M.; Conticelli, S.; Innocenti, F.; Manetti, P.; Sokoutis, D. (2003). Analogue modelling of continental extension: a review focused on the relations between the patterns of deformation and the presence of magma. Earth Science Reviews, 63: 169-247. 
Cunha, H.C.S.; Dheler, N.M.; Vieira, V.S.; Raposo, F.O.; Perillo, I.A.; Silva, P.C.S. (2000). Mapa Geológico do Estado do Rio de Janeiro. Companhia de Pesquisa de Recursos Minerais, Brasil.

Deckart, K.; Féraud, G.; Marques, L.S.; Bertrand, H. (1998). New time constraints on dyke swarms related to the Paraná-Etendeka magmatic province, and subsequent South Atlantic opening, southeastern Brazil. Journal of Volcanalogy and Geothermal Research, 80:7-83.

De La Roche, H. ; Leterrier, J.; Grandclaude, P; Marchal, M. (1980). A classification of volcanic and plutonic rocks using R1-R2 diagram and major element analyses - its relationships with current nomenclature. Chemical Geology, 29: 183-210.

De Paolo, D. J. (1981a). A Neodymium and strontium isotopic study of the Mesozoic calcalkaline granitic batholiths of the Sierra Nevada and Peninsular Ranges, California. Journal of Geophysical Research, 86: 10470-10488.

De Paolo, D.J. (1981b). Trace element and isotopic effects of combined wallrock assimilation and fractional crystallisation. Earth and Planetary Science Letters,53: 189-202.

Dong, H.; Hall, C.M.; Halliday, A.N. (1995). Mechanisms of argon retention in clays revealed by laser 40Ar-39Ar dating. Science, 267: 355-359.

Dostal, J.; Dupuy, C.; Carron, J.P.; Dekerneizon, M.L.; Maury, R.C. (1983). PartitionCoefficients of Trace-Elements - Application to Volcanic Rocks of St-Vincent, WestIndies. Geochimica et Cosmochimica Acta, 47(3): 525-533.

Dunn, T. and Sen, C. (1994). Mineral/Matrix Partition-Coefficients for Ortho-Pyroxene, Plagioclase, and Olivine in Basaltic to Andesitic Systems - a Combined Analytical and Experimental Study. Geochimica et Cosmochimica Acta, 58(2): 717-733.

Dutra T. (2006). Petrogênese dos basaltos de baixo-TiO2 do Enxame de Diques daSerra do Mar na Região dos Lagos, RJ. Dissertação de Mestrado, Universidade do Estado do Rio de Janeiro.

Ernesto, M.; Raposo, M.I.B; Marques, L.S.; Renne, P.R.; Diogo, L.A.; De Min, A. (1999). Paleomagnetism, geochemistry and 40Ar/39Ar dating of the North-eastern Paraná magmatic province: tectonic implications. Journal of Geodynamics, 28:321-340.

Ernesto, M.; Marques, L.S.; Piccirillo, E.M.; Molina, E.C.; Ussami, N.; Comin-Chiaramonti, P.; Bellieni, G. (2002). Paraná Magmatic Province- Tristan da Cunha plume system: fixed versus mobile plume, petrogenetic considerations and alternative heat sources. Journal of Volcanology and Geothermal Research, 118:15-36.

Ernesto, M.; Marques, L.S.; Bucceroni, C.S. - 2014. Atividade Ígnea filoniana ao longo da faixa costeira entre Santos-Cabo Frio: comparações geoquímicas, geocronológicas e paleomagnéticas. 47을 Congresso Brasileiro de Geologia, Salvador-BA, CD-ROM. 
Ernst, R.E.; Buchan, K.L. (1997). Giant radiating dyke swarms: their use in identifying preMesozoic large igneous provinces and mantle plumes. In: Mahoney J., Coffin M. Large Igneous Provinces: Continental, Oceanic, and Planetary Volcanism. AGU Geophysics Monograph Series, 100: 297-333.

Ewart, A.; Milner, S.C.; Armstrong, R.A.; Duncan, A.R. (1998). Etendeka volcanism of the Goboboseb Mountains and Messum Igneous Complex, Namibia. Journal of Petrology, 39(2):191225.

Ewart, A.; Marsh, J.S.; Milner, S.C.; Duncan, A.R.; Kamber, B.S.; Armstrong, R.A. (2004). Petrology and geochemistry of Early Cretaceous bimodal continental volcanism of the NW Etendeka, Namibia. Journal of Petrology, 45:59-105.

Faure, G. \& Mensing, T.M. (2005). Isotopes: principles and applications. Wiley, New Jersey, United States.

Florisbal, L.M. (2011). Petrogênese de granitos sintectônicos em ambiente pós-colisional do escudo catarinense: estudo integrado de geologia estrutural, geoquímica Elemental e isotópica $\mathrm{Sr}-\mathrm{Nd}$-Pb e geocronologia U-Pb em zircão. Tese de Doutorado, Universidade de São Paulo.

Florisbal, L.M.; Heaman, L.M.; Janasi, V.A.; Bitencourt, M.F. (2014). Tectonic significance of the Florianopolis Dyke Swarm, Parana-Etendeka Magmatic Province: a reappraisal based on precise U-Pb dating. Journal of Volcanology and Geothermal Research, 289: 140-150.

Fonseca, A.C. (1993). Esboço geocronológico da região de Cabo Frio - Estado do Rio de Janeiro. Tese de Doutorado, Universidade de São Paulo.

Fujimaki, H.; Tatsumoto, M.; Aoki, K.-i. (1984). Partition coefficients of Hf, Zr, and REE between phenocrysts and groundmasses. Journal of Geophysical Research, 89: 662-672.

Garda, G.M. (1995). Os diques básicos e ultrabásicos da região costeira entre as cidades de São Sebastião e Ubatuba, Estado de São Paulo. Tese de Doutorado, Instituto de Geociências - Universidade de São Paulo.

Garda, G.M. \& Schorscher, J.H.D. (1996). Os diques costeiros básicos e ultrabásicos adjacentes ao canal de São Sebastião (litoral norte do Estado de São Paulo). Revista do Instituto Geológico, 17(1/2): 7-31.

Gibson, S.A; Thompson, R.N.; Leonardos, O.H.; Dickin, A.P.; Mitchell, J.G. (1999). The limited extent of plume-lithosphere interactions during continental flood-basalt genesis: geochemical evidence from Cretaceous magmatism in southern Brazil. Contributions to Mineralogy and Petrology, 137:147-169.

Guedes, E.; Heilbron, M.; Vasconcelos, P.; Valeriano, C.M.; Almeida, J.C.H; Teixeira, W.; Thomaz Filho, A. (2005). K-Ar and Ar-Ar ages of dikes emplaced in the onshore basement of 
Santos Basin, Resende Area, SE, Brazil: Implications for the South Atlantic opening and a Tertiary reactivation. Journal of South American Earth Sciences, 18: 145-178.

Guedes, E. (2007). O enxame de diques da Serra do Mar na região entre Resende e a Baía da Ilha Grande, RJ. Tese de Doutorado, Universidade do Estado do Rio de Janeiro.

Guedes, E.; Heilbron, M.; Valeriano, C.M.; Almeida, J.C.H.; Szatmari, P. (2016). Evidence of Gondwana early rifting process recorded by Resende-Ilha Grande Dike Swarm, southern Rio de Janeiro, Brazil. Journal of South American Earth Sciences, 67: 11-24.

Hafner, B. (2007). Scanning Electron Microscopy Primer. Characterization Facility, University of Minnesota.

Harman, R.; Gallagher, K.; Brown, R.; Raza, A.; Bizzi, L. (1998). Accelerated denudation and tectonic/geomorphic reactivation of the cratons of northeastern Brazil during the Late Cretaceous. Journal of Geophysical Research, 103: 27091-27105.

Hawkesworth, C.J.; Gallager, K.; Kelley, S., Mantovani, M.S.M.; Peate, D.; Regelous, M.; Rogers, N. (1992). Paraná magmatism and the opening of the South Atlantic. In: Storey, B.; Alabaster, A.;Pankhurst, R. Magmatism and the Causes of Continental Break-up. Geological Society Special Publication, 68:221-240.

Heilbron, M. \& Machado, N. (2003). Timing of terrane accretion in the NeoproterozoicEopaleozoic Ribeira belt SE Brazil. Precambrian Research, 125:87-112.

Heilbron, M.; Soares, A.C.P.; Campos Neto, M.; Silva, L.C.; Trouw, R. ; Janasi, V. (2004). Província Mantiqueira. In: Mantesso-Neto, V.; Bartorelli, A.; Carneiro, C.D.R.; Brito Neves, B.B. Geologia do Continente Sul Americano: Evolução da Obra de Fernando Flávio Marques de Almeida, Beca, 203-234.

Huang, Y.; Calsteren, P.V.; Hawkesworth, C.I. (1995). The evolution of the lithosphere in southern Africa: A perspective on the basic granulite xenoliths from kimberlites in South Africa. Geochimica et Cosmochimica Acta, 59 (23): 4905-4920.

Irvine, T.N. \& Baragar, W.R.A. (1971). A guide to the chemical classification of the commonvolcanic rocks. Canadian Journal of Earth Sciences, 8: 523-548.

Jackson, M.G. \& Dasgupta, R. (2008). Compositions of HIMU, EM1, and EM2 from Global Trends between Radiogenic Isotopes and Major Elements in Ocean Island Basalts. Earth and Planetary Science Letters, 276: 175-186.

Japsen, P.; Bonow, J.; Green, P.F.; Cobbold, P.R.; Chiossi, D.; Lilletveit, R.; Magnavita, L.P.; Pedreira, A. (2012b). Episodic burial and exhumation in NE Brazil after opening of the South Atlantic. Geological Society of America Bulletin, 124: 800-816.

Kawashita, K. (1972). O método Rb-Sr em rochas sedimentares. Tese de doutorado, Universidade de São Paulo. 
Kelley, S. (2002). Excess argon in K-Ar and Ar-Ar geochronology. Chemical Geology, 188: $1-22$.

Kuno, H. (1968). Differentiation of basalt magmas. In: Hess, H.H. \&Pol de- Vaart, A. Basalts, vol. II, Wiley Intersciences Publications, New York, United States.

Lavecchia, A.; Clark, S.R.; Beekman, F.; Cloetingh, S. A. P. L.; Burov, E. (2016). Thermal perturbation, mineral assemblages, and rheology variations induced by dyke emplacement in the crust. Tectonics: $35,1137-1152$.

Le Bas, M.J.; Le Maitre, R.W.; Streckeisen ; A., Zanettin, B. (1986). A chemical classification of volcanic rocks based on the Total Alkali-Silica diagram. Journal of Petrology, 27(3): 745-750.

Markowicz, A.A. (2002). X-Ray Physics. In: Griecken, R.E.V. \& Markowicz, A.A. Handbook of X-Ray Spectrometry, Marcel Dekker, New York, United States.

Marques, L.S.; Dupré, B.; Piccirillo, E.M. (1999). Mantle source compositions of the Paraná Magmatic Province: evidence from trace element and $\mathrm{Sr}-\mathrm{Nd}-\mathrm{Pb}$ isotope geochemistry. Journal of Geodynamics, 28:439-459.

Marques, L.S. (2001). Geoquímica dos diques toleíticos da costa sul-sudeste do Brasil: contribuição ao conhecimento da Província Magmática do Paraná. Tese de Livre Docência, Universidade de São Paulo.

Marques, L.S. \& Ernesto, M. (2004). O magmatismo toleítico da Bacia do Paraná. Geologia do Continente Sul-Americano. In: Mantesso-Neto, V.; Bartorelli, A.; Carneiro, C. D. R.; BritoNeves, B.B. Geologia do Continente Sul-Americano: Evolução da Obra de Fernando Flávio Marques de Almeida, Beca, 245-263.

Marques, L. S.; Ernesto, M.; Piccirillo, E. M.; Bellieni, G.; Figueiredo, A. M. G.; Min, A. (2005). Identificação de diferentes pulsos magmáticos no Enxame de Diques Toleíticos da Serra do Mar. Anais do III Simpósio de Vulcanismo e Ambientes Associados, 289-293.

Marques, L.S.; Rocha-Júnior, E.R.V.; Babinski, M.; Carvas, K.Z.; Petronilho, L.A.; De Min, A. (2016). Lead Isotope constraints on mantle sources involved in the genesis of Mesozoic high-Ti tholeiite dykes (Urubici type) from the São Francisco Craton (Southern Espinhaço). Journal of Brazilian Geology, 46: 105-122.

Marzoli, A.; Melluso, L.; Morra, V.; Renne, P.R.; Sgrosso, I.; D’antonio, M.; Morais, L.D.; Morais, E.A.A.; Ricci, G. (1999). Geochronology and petrology of Cretaceous basaltic magmatism in the Kwanza basin (western Angola), and relationships with the Paraná-Etendeka continental flood basalt province. Journal of Geodynamics, 28:341-356.

McDonough, W.F. \& Sun, S. (1995). The composition of the Earth. Chemical Geology, 120 : 223-253. 
McDougall, I. \& Harrison, T.M. (1999). Geochronology and Thermochronology by the ${ }^{40} \mathrm{Ar} /{ }^{\beta 9} \mathrm{Ar}$ method. Oxford University Press, England.

McKay, G.A. \& Weill, D.F. (1977). KREEP petrogenesis revisited. Journal of Geophysical Research, 2,339-355.

Milner, S.C. \& Le Roex, A.P. (1996). Isotope characteristics of the Okenyenya igneous complex, northern Namibia: constraints on the composition of the early Tristan Plume and the origin of theEM1 mantle component. Earth and Planetary Science Letters, 141:277-291.

Mitchell, J.G. (1968). The argon-40/argon-39 dating method for potassium-argon age determination. Geochimica et Cosmochimica Acta, 32: 781-790.

Mizusaki, A.M.P.; Petrini, R.; Bellieni, G.; Comin-Chiaramonti, P.; Dias, J.; De Min, A.; Piccirillo, E.M. (1992). Basalt magmatism along the passive continental margin of SE Brazil (Campos Basin). Contributions to Mineralogy and Petrology, 111:143-160.

Monié, P.; Bosch, D.; Bruguier, O.; Vauchez, A.; Rolland, Y.; Nsungani, P.; Buta Neto, A. (2012). The Late Neoproterozoic/Early Palaeozoic evolution of the West Congo Belt of NW Angola: geochronological (U-Pb and $\mathrm{Ar}-\mathrm{Ar}$ ) and petrostructural constraints. Terra Nova, 24(3): 238-247.

Mohriak, W. U.; Nemçok, M.; Enciso, G. (2008). South Atlantic divergent margin evolution: Rift-border uplift and salt tectonics in the basinsof SE Brazil, in West Gondwana - Pre-Cenozoic Correlations Across the South Atlantic Region. Geological Society Special Publications, 294: 365398.

Nardy A.J.R. (1996). Geologia e petrologia do vulcanismo mesozoico da região central da Bacia do Paraná. Tese de Doutorado, Universidade Estadual Paulista.

Nemec, D. (1966). Plagioclase albitization in the lamprophyric and lamproid dykes at the Eastern border of the Bohemian Mass. Contributions to Mineralogy and Petrology, 12:340-353.

Nier, A.O. (1950). A redetermination of the relative abundances of the isotopes of carbon, nitrogen, oxygen, argon, and potassium. Physics Reviews, 77: 789-793.

Nobre Silva I.G.; Weis D.; Barling J.; Scoates J.S. (2009). Leaching systematics and matrix elimination for the determination of high-precision $\mathrm{Pb}$ isotope compositions of ocean island basalts. Geochemistry, Geophysics, Geosystems, 10(8):1-23.

Peate, D.W.; Hawkesworth, C.J. \& Mantovani, M.S.M. (1992). Chemical stratigraphy of the Paraná lavas, South America: classification of magma types and their spatial distribution. Bulletin of Volcanology, 55: 119-139.

Peate, D.W. (1997). The Paraná-Etendeka Province. In: Mahoney, J.J.; Coffin, M. Large Igneous Provinces, American Geophysical Union Geophysical Monograph Series, 100: 217-245 
Peate, D.W.; Hawkesworth, C.J.; Mantovani, M.S.M.; Rogers, N.W. \& Turner, S.P. (1999). Petrogenesis and stratigraphy of the high-Ti/Y Urubici magma type in the Paraná flood basalt province and implications for the nature of 'Dupal'- type mantle in the South Atlantic region. Journal of Petrology, 40(3):451-473.

Peixoto, C.; Heilbron, M.; Ragatky, D.; Armstrong, R.; Dantas, E.; Valeriano, C.; Simonetti, A. (2016). O arco toniano da Faixa Ribeira e suas implicações na amalgamação do Gondwana Ocidental. Anais do 48 Congresso Brasileiro de Geologia.

Piccirillo, E. M \& Melfi, A. J. (1988). The Mesozoic flood volcanism of the Paraná Basin: petrogenetic and geophysical aspects. In: Santero, P.; Zadro, M.; Blitzkow, D.; De Sá, N.C. Instituto Astronômico e Geofísico, Universidade de São Paulo.

Piccirillo, E.M.; Bellieni, G.; Cavazzini, G.; Comin-Chiaramonti, P.; Petrini, R.; Melfi, A.J.; Pinese, J.P.P.; Zantadeschi, P.; De Min, A. (1990). Lower cretaceous tholeiitic dyke swarms from the Ponta Grossa Arch (southeast Brazil): Petrology, $\mathrm{Sr}-\mathrm{Nd}$ isotopes and genetic relationships with the Paraná flood volcanics. Chemical Geology, 89:19-48.

Pringle, G.J.; Trembath, L.T.; Pajari, G.E., Jr. (1974). Crystallization history of a zoned plagioclase. Mineralogical Magazine, 39: 867-877.

Raposo, M.I.B.; Ernesto, M.; Renne, P.R. (1998). Paleomagnetism and 40Ar/39Ar dating of the Early Cretaceous Florianópolis dike swarm (Santa Catarina Island), Southern Brazil. Physics of the Earth and Planetary Interiors, 108: 275-290.

Renne, P.R.; Mertz, D.F.; Ernesto, M.; Marques, L.S.; Teixeira, W.; Ens, H.H.; Richards, M.A. (1993). Geochronologic constrains on magmatic and tectonic evolution of the Paraná Province. EOS, American Geophysical Union, 26:553.

Renne, P.R.; Glen, J.M.; Milner, S.C. \& Duncan, A.R. (1996b). Age of Etendeka flood volcanism and associated intrusions in southwestern Africa. Geology, 24: 659-662.

Renne, P.R., 2000. K-Ar and 40Ar/39Ar Dating. In: Noller, J.S. Quaternary Geochronology: Methods and Applications. American Geophysical Union, Washington, United States.

Renne, P.R.; Swisher, C.C.; Deino, A.L.; Karner, D.B.; Owens, T.L., DePaolo, D.J. (1998). Intercalibration of standards, absolute ages and uncertainties in 40Ar/39Ar dating. Chemical Geology, 145: 117-152.

Riley, T. R.; Leat, P. T.; Curtis, M. L.; Millar, L. L.; Fazel, A. (2005). Early-Middle Jurassic dolerite dykes from western Dronning Maud Land (Antarctica): identifying mantle sources in the Karoo large igneous province. Journal of Petrology, 46: 1489-1524.

Rocha Júnior, E.R.V. (2010). Sistemática isotópica de Os - Nd - Pb - Sr e geoquímica de elementos traço litófilos e siderófilos de basaltos da Província Magmática do Paraná. Tese de Doutorado, Universidade de São Paulo. 
Rocha-Júnior, E.R.V.; Puchtel, I.S.; Marques, L.S.; Walker, R.J.; Machado, F.B.; Nardy, A.J.R.; Babinski, M.; Figueiredo, A.M.G. (2012). Re-Os isotope and highly siderophile element systematics of the Paraná Continental Flood Basalts (Brazil). Earth and Planetary Science Letters, 337-338:164-173.

Rocha-Júnior, E.R.V.; Marques, L.S.; Babinski, M.; Nardy, A.J.R.; Figueiredo, A.M.G.; Machado, F.B. (2013). Sr-Nd-Pb isotopic constraints on the nature of the mantle sources involved in the genesis of the high-Ti tholeiites from Northern Paraná Continental Flood Basalts (Brazil). Journal of South American Earth Sciences, 46:9-25.

Rollinson, H.R. (1993). Using geochemical data: evaluation, presentation, interpretation. Pearson, Prentice Hall, Essex, England.

Rudnick, R. L. \& Gao, S. (2003). Composition of the continental crust. In: Holland, H.D. \& Turekian, K.K. Treatise on Geochemistry, 3: 1-64.

Sato, K.; Tassinari, C. G. C.; Kawashita, K. \& Petronillo, L. (1995). O método geocronológico Sm-Nd no IG-USP e suas aplicações. Anais da Academia Brasileira de Ciências, 67: 313-336.

Schmitt, A.K.; Emmermann, R.; Trumbull, R.B.; Buhn, B.; Henjes-Kunst, F (2000). Petrogenesis and 40Ar/39Ar geochronology of the Brandberg complex, Namibia: evidence for a major mantle contribution in metaluminous and peralkaline granites. Journal of Petrology, 41: 1207-1239.

Schmitt, R.S.; Trouw, R.A.J.; Van Schumus, W.R.; Pimentel, M.M. (2004). Late amalgamation in the central part of West Gondwana: new geochronological data and the characterization of a Cambrian collisional orogeny in the Ribeira Belt (SE Brazil). Precambrian Research, 113: 29-61.

Schmitt, R.S.; Trouw, R.; Van Schmus, W.R.; Armstrong, R.; Stanton, N.S.G. (2016). The tectonic significance of the Cabo Frio Tectonic Domain in the SE Brazilian margin: a Paleoproterozoic through Cretaceous saga of a reworked continental margin. Brazilian Journal of Geology, 46 (1): 37-66.

Stanton, N.; Schmitt, R.S.; Galdeano, A.; Maia, M.; Mane, M. (2010). Crustal Structure of the Southeastern Brazilian Margin, Campos Basin, from Aeromagnetic Data: New kinematic constraints. Tectonophysics, 490:15-27.

Stanton, N. \& Schmitt, R. (2015). Onshore-offshore prolongation of structures between Campos and Santos Basins from aeromagnetic data. $14^{\text {th }}$ International Congress of the Brazilian Geophysical Society.

Steiger, R.H. \& Jäger, E. (1977). Subcomission on geochronology: convention on the use of decay constants in geo and cosmochronology. Earth and Planetary Science Letters, 36: 359362. 
Thiede, D.S. \& Vasconcelos, P.M. (2010). Parana flood basalts: Rapid extrusion hypothesis confirmed by new 40Ar/39Ar results. Geology, 38(8): 747-750.

Thomas, R. (2004). Practical guide to ICP-MS. Marcel Dekker, New York, United States.

Thompson, R.N.; Gibson, S.A.; Dickin, A.P.; Smith, P.M. (2001). Early Cretaceous basalt and picrite dykes of the southern Etendeka region, NW Namibia: windows to the role of the Tristan mantle plume in Paraná-Etendeka magmatism. Journal of Petrology, 11: 2049-2081.

Turner, G. \& Cadogan, P.H. (1974). Possible effects of 39Ar recoil in 40Ar-39Ar dating. Geochimica et Cosmochimica Acta, Proceedings of the Fifth Lunar Science Conference: 16011615.

Turner, S.; Regelous, M.; Kelley, S.; Hawkesworth, C.; Mantovani, M. (1994). Magmatism and continental break-up in the South Atlantic: high precision 40Ar/39Ar geochronology. Earth and Planetary Science Letters, 121:333-348.

Ussami, N.; Chaves, C. A. M.; Marques, L. S.; Ernesto, M. (2012). Origin of the Rio Grande Rise-Walvis Ridge reviewed integrating palaeogeographic reconstruction, isotope geochemistry and flexural modelling. Geological Society, London, Special Publications, 369(1): 129-146.

Vicentini, C.M. (2015). Caracterização geoquímica e isotópica (Sr-Nd-Pb) dos litotipos subalcalinos diferenciados do Enxame da Serra do Mar. Dissertação de Mestrado, Universidade de São Paulo.

Valente, S.C. (1997). Geochemical and isotopic constraints on the petrogenesis of the Cretaceous dykes of Rio de Janeiro, Brazil. Tese de Doutorado, The Queen's University of Belfast.

Valente, S.C.; Corval, A.; Duarte, B.P.; Ellam, R.B.; Fallick, A.E.; Dutra, T. (2007). Tectonic boundaries, crustal weakness zones and plume-subcontinental lithospheric mantle interactions in the Serra do Mar Dyke Swarm, SE Brazil. Revista Brasileira de Geociências, 37 (1): 194 - 201.

Vanhaecke, F. (2012). Single-collector inductively coupled plasma mass spectrometry. In: Vanhaecke, F. \& Degryse, P. Isotopic Analysis. Wiley-VCH, Weinheim, Germany.

Vasconcelos, P.M.; Onoe, A.T.; Kawashita, K.; Soares, A.J.; Teixeira, W. (2002). 40Ar/39Ar geochronology at the Instituto de Geociências, USP: instrumentation, analytical procedures, and calibration. Anais da Academia Brasileira de Ciências, 74: 297-342.

Wilson, M. (1989). Igneous petrogenesis. Unwin Hyman, London, England.

Workman, R.K. \& Hart, S.R. (2005). Major and trace element composition of the depleted MORB mantle (DMM). Earth and Planetary Science Letters, 231: 53-72.

Zanettin, B. (1984). Proposed new chemical classification of volcanic rocks. Episodes, 7: 19-20.

Zindler, A.; Hart, S. (1986). Chemical geodynamics. Annual Review of Earth and Planetary Sciences, 14: 493-571. 
APÊNDICES 
APÊNDICE A

Tabela A.1: Determinações de elementos traço $(\mu \mathrm{g} / \mathrm{g})$ via FRX.

\begin{tabular}{|c|c|c|c|c|c|c|c|c|c|c|c|c|c|c|c|}
\hline Amostra & $\mathrm{Cr}$ & $\mathrm{Ni}$ & $\mathrm{Ba}$ & $\mathbf{R b}$ & $\mathrm{Sr}$ & La & $\mathrm{Ce}$ & $\mathrm{Zr}$ & $\mathbf{Y}$ & $\mathrm{Nb}$ & $\mathrm{Cu}$ & $\mathrm{Zn}$ & Co & v & Ga \\
\hline LM-BZ 4R & 130,7 & 68,4 & 151 & 15,1 & 184,3 & 14,2 & 24,9 & 77,6 & 26,3 & 9,5 & 178 & 83 & 41,1 & 392 & 17,2 \\
\hline LM-BZ 5R & 142,4 & 68,1 & 120 & 13,7 & 181,8 & 11 & 26,5 & 77,6 & 26,6 & 8,4 & 178 & 83 & 43,1 & 402,3 & 17,4 \\
\hline LM-BZ 6R & 126,2 & 37,2 & 222 & 18,7 & 268,2 & 17,8 & 49,2 & 143,9 & 29,3 & 13,7 & 117 & 119 & 29,6 & 297,5 & 19,6 \\
\hline LM-BZ 15 & 154,8 & 53,7 & 381 & 24,4 & 212,3 & 16,2 & 44,8 & 120,3 & 33,5 & 12,3 & 236 & 93 & 38,1 & 466,9 & 19,1 \\
\hline LM-DA 150 & 210,5 & 96,4 & 145 & 16,3 & 193,9 & 13 & 20,1 & 70,6 & 24,1 & 8,7 & 149 & 77 & 46,8 & 326,7 & 17,6 \\
\hline LM-DA 152 & 302,1 & 65,6 & 109 & 15,8 & 223,7 & 15,4 & 34,8 & 88,1 & 23,5 & 8,5 & 111 & 80 & 31 & 241,7 & 18,4 \\
\hline LM-DA 155 & 149,3 & 52,7 & 215 & 16 & 241 & 16 & 31,3 & 102,8 & 25,4 & 9,4 & 138 & 84 & 31,2 & 295,7 & 18,8 \\
\hline LM-DA 158 & 196,8 & 70 & 82 & 16,4 & 201,8 & 14 & 29,1 & 93,1 & 28,5 & 10,2 & 228 & 83 & 46,5 & 501,8 & 18,2 \\
\hline LM-DA 161 & 201,3 & 54 & 260 & 13,8 & 205,7 & 9,2 & 40,9 & 117,4 & 32,6 & 12,8 & 256 & 104 & 45,9 & 463 & 18,9 \\
\hline LM-DA 182 & 216,1 & 75,7 & 167 & 13,3 & 186,3 & 9,5 & 10,4 & 60,7 & 25,1 & 7,2 & 157 & 82 & 45,2 & 338,8 & 17,4 \\
\hline LM-DA 183 & 129 & 45,3 & 332 & 28,4 & 195,5 & 70,1 & 84,7 & 109,6 & 48,4 & 8,7 & 79 & 105 & 41,9 & 453 & 18,5 \\
\hline LM-DA 200 & 161,8 & 41,7 & 218 & 15,7 & 222,4 & 7,5 & 24,8 & 111,3 & 28,9 & 9,9 & 151 & 90 & 43,3 & 372,5 & 19,6 \\
\hline LM-DA 203 & 213,5 & 98,4 & 105 & 12,4 & 182 & 21,2 & 14,3 & 60,4 & 22,4 & 5,9 & 143 & 72 & 44,5 & 337,5 & 17,7 \\
\hline LM-DA 204 & 314,7 & 105,7 & 105 & 16,9 & 201 & 5,1 & 30,5 & 84,7 & 24,3 & 10 & 176 & 75 & 36,7 & 339,2 & 17,9 \\
\hline LM-DA 205 & 143,3 & 71,9 & 134 & 14,1 & 180,4 & 9,4 & 31,9 & 77,6 & 26,8 & 9,3 & 177 & 78 & 41,8 & 374,3 & 17,5 \\
\hline LM-DA 206 & 199,8 & 82,5 & 114 & 12,5 & 197 & 13,6 & 22,2 & 75,3 & 24,2 & 10,4 & 163 & 78 & 41,8 & 369,6 & 17,4 \\
\hline LM-DA 207 & 146,5 & 42 & 256 & 19,3 & 232,8 & 19,4 & 51,9 & 144,1 & 32,1 & 11,9 & 184 & 106 & 37,7 & 385,3 & 20 \\
\hline LM-DA 208 & 363,9 & 125,9 & 151 & 14,1 & 179,2 & 12,7 & 18,1 & 67,9 & 23,3 & 8,8 & 151 & 71 & 48,6 & 353,7 & 17,5 \\
\hline LM-DA 209 & 259,2 & 64,1 & 202 & 16,4 & 202,2 & 17,8 & 25,3 & 111,4 & 28,8 & 10,3 & 162 & 94 & 43 & 348,9 & 19,4 \\
\hline LM-DA 210 & 317,7 & 116,5 & 63 & 12,9 & 222,2 & 12 & 37,7 & 90,4 & 23,9 & 10,6 & 119 & 84 & 34,1 & 225 & 17,9 \\
\hline LM-DA 211 & 136,7 & 38,9 & 132 & 26,1 & 269,1 & 1,8 & 49 & 140 & 29,2 & 11,6 & 107 & 98 & 24,6 & 242,8 & 19,3 \\
\hline LM-DA 212 & 186,5 & 47,7 & 169 & 18,6 & 235,9 & 4,9 & 30,6 & 105,5 & 27,3 & 10,1 & 139 & 84 & 35,8 & 285 & 19,1 \\
\hline
\end{tabular}


APÊNDICE B

Tabela B.1: Valores de concentração de elementos traço $(\mu \mathrm{g} / \mathrm{g})$ obtidos e certificados para o padrão BRP-1 nas análises de ICP-MS.

\begin{tabular}{|c|c|c|c|}
\hline Elemento & Obtido & Certificado & $\sigma_{\text {CERTIFICADO }}$ \\
\hline $\mathrm{Li}$ & 7,0 & 7,1 & 0,3 \\
\hline $\mathrm{Be}$ & 1,8 & 1,8 & 0,1 \\
\hline Sc & 27,0 & 28,5 & 0,8 \\
\hline V & 351 & 391 & 7 \\
\hline $\mathrm{Cr}$ & 6,64 & 12,4 & 1 \\
\hline Co & 37,6 & 37,5 & 1,4 \\
\hline $\mathrm{Ni}$ & 24,2 & 23,4 & 0,9 \\
\hline $\mathrm{Cu}$ & 161 & 160 & 3 \\
\hline $\mathrm{Zn}$ & 138 & 142 & 2 \\
\hline Ga & 25,0 & 24,8 & 0,6 \\
\hline $\mathrm{Rb}$ & 44,7 & 35,4 & 1 \\
\hline $\mathrm{Sr}$ & 470 & 492 & 6 \\
\hline $\mathrm{Y}$ & 42,2 & 42 & 1 \\
\hline $\mathrm{Zr}$ & 298 & 310 & 5 \\
\hline $\mathrm{Nb}$ & 31,0 & 29,1 & 0,9 \\
\hline Mo & 1,5 & 1,5 & 0,1 \\
\hline $\mathrm{Cd}$ & 0,1 & 0,2 & 0,1 \\
\hline Sn & 2,3 & 2,5 & 0,4 \\
\hline $\mathrm{Sb}$ & 0,07 & 0,06 & 0,01 \\
\hline Cs & 0,37 & 0,37 & 0,02 \\
\hline $\mathrm{Ba}$ & 576 & 555 & 7 \\
\hline La & 43,7 & 42,6 & 1 \\
\hline $\mathrm{Ce}$ & 98,2 & 93,3 & 1,2 \\
\hline $\operatorname{Pr}$ & 12,0 & 12,3 & 0,2 \\
\hline $\mathrm{Nd}$ & 50,3 & 51,9 & 0,9 \\
\hline Sm & 11,2 & 11,2 & 0,2 \\
\hline Eu & 3,36 & 3,42 & 0,08 \\
\hline Gd & 10,0 & 10,4 & 0,3 \\
\hline $\mathrm{Tb}$ & 1,50 & 1,52 & 0,05 \\
\hline Dy & 8,6 & 8,5 & 0,3 \\
\hline Ho & 1,65 & 1,62 & 0,06 \\
\hline $\mathrm{Er}$ & 4,0 & 4,2 & 0,1 \\
\hline $\mathrm{Tm}$ & 0,56 & 0,57 & 0,02 \\
\hline $\mathrm{Yb}$ & 3,45 & 3,48 & 0,09 \\
\hline Lu & 0,5 & 0,5 & 0,02 \\
\hline $\mathrm{Hf}$ & 7,81 & 8 & 0,2 \\
\hline Ta & 1,86 & 1,96 & 0,08 \\
\hline $\mathrm{Pb}$ & 5,1 & 5,5 & 0,3 \\
\hline Th & 4,24 & 3,97 & 0,1 \\
\hline U & 0,90 & 0,82 & 0,03 \\
\hline
\end{tabular}




\section{APÊNDICE C}

Figura C.1: Espectro de idades obtido para o padrão GA-1550 (98,8 $\pm 0,5$ Ma; Renne et al., 1998), utilizado nas datações ${ }^{40} \mathrm{Ar} /{ }^{39} \mathrm{Ar}$.

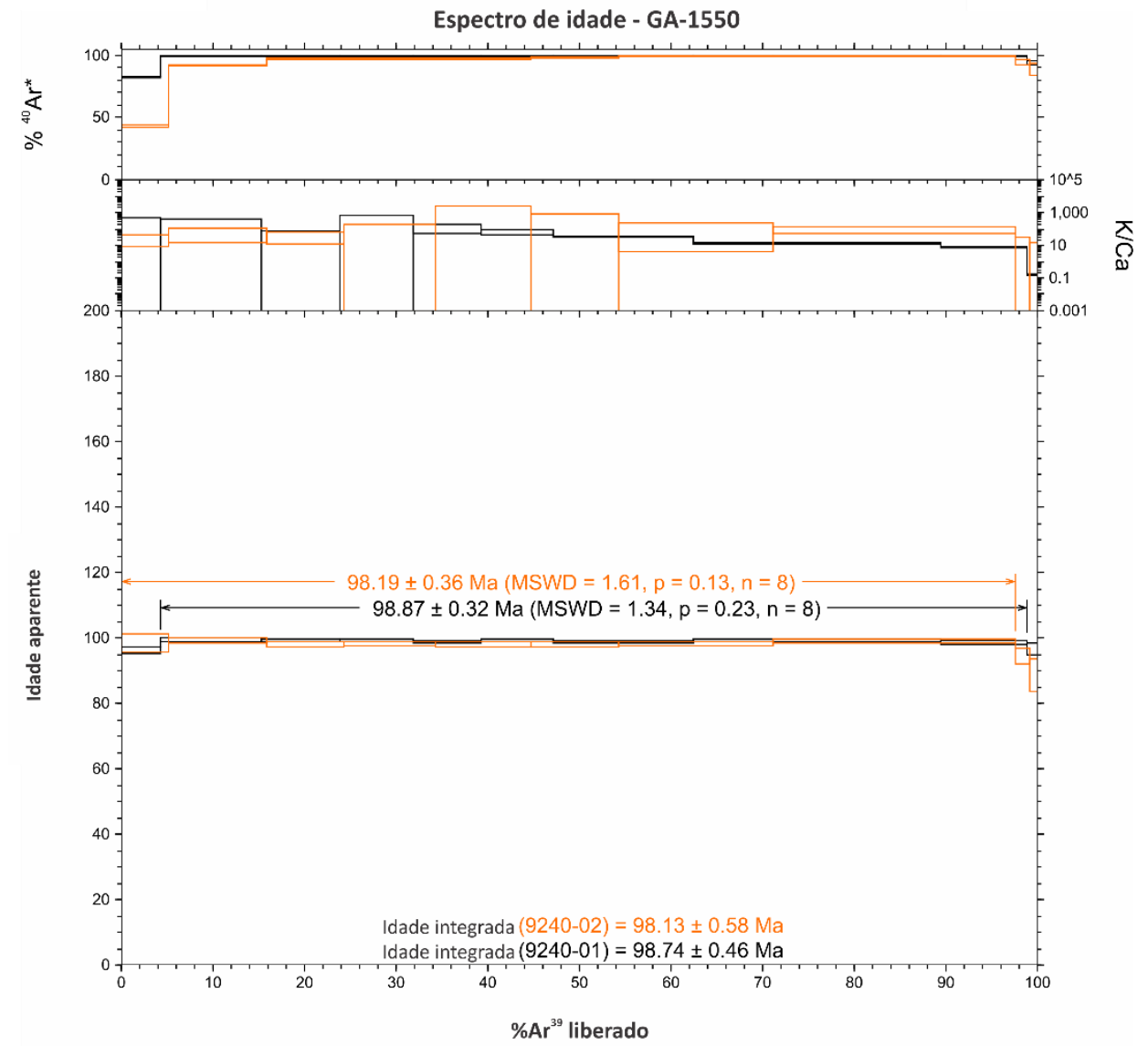

Figura C.2: Isócrona obtida para o padrão GA-1550, utilizado nas datações ${ }^{40} \mathrm{Ar} /{ }^{39} \mathrm{Ar}$.

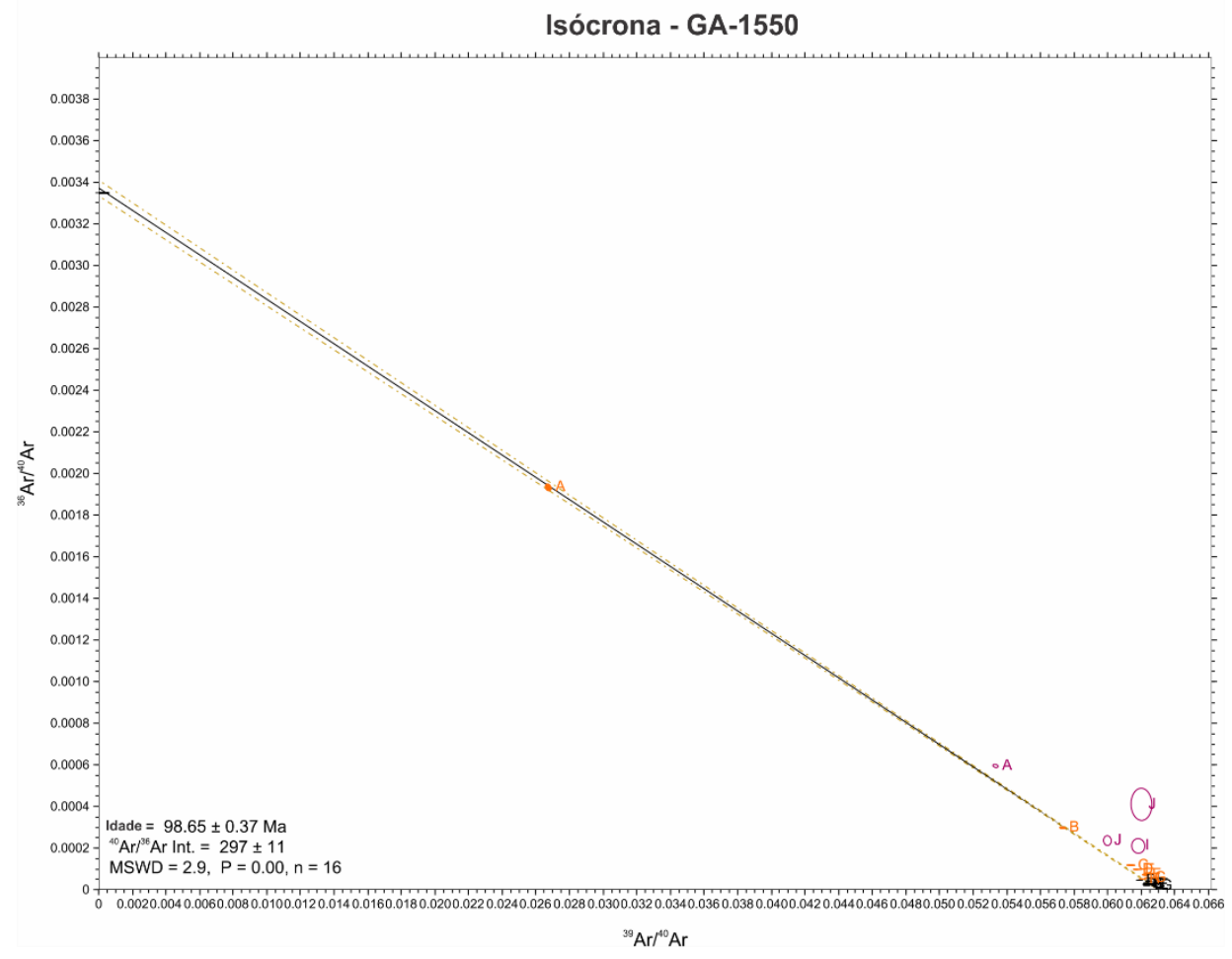


Figura C.3: Diagrama de probabilidade de idades obtido para o padrão GA-1550, utilizado nas datações ${ }^{40} \mathrm{Ar} /{ }^{39} \mathrm{Ar}$.

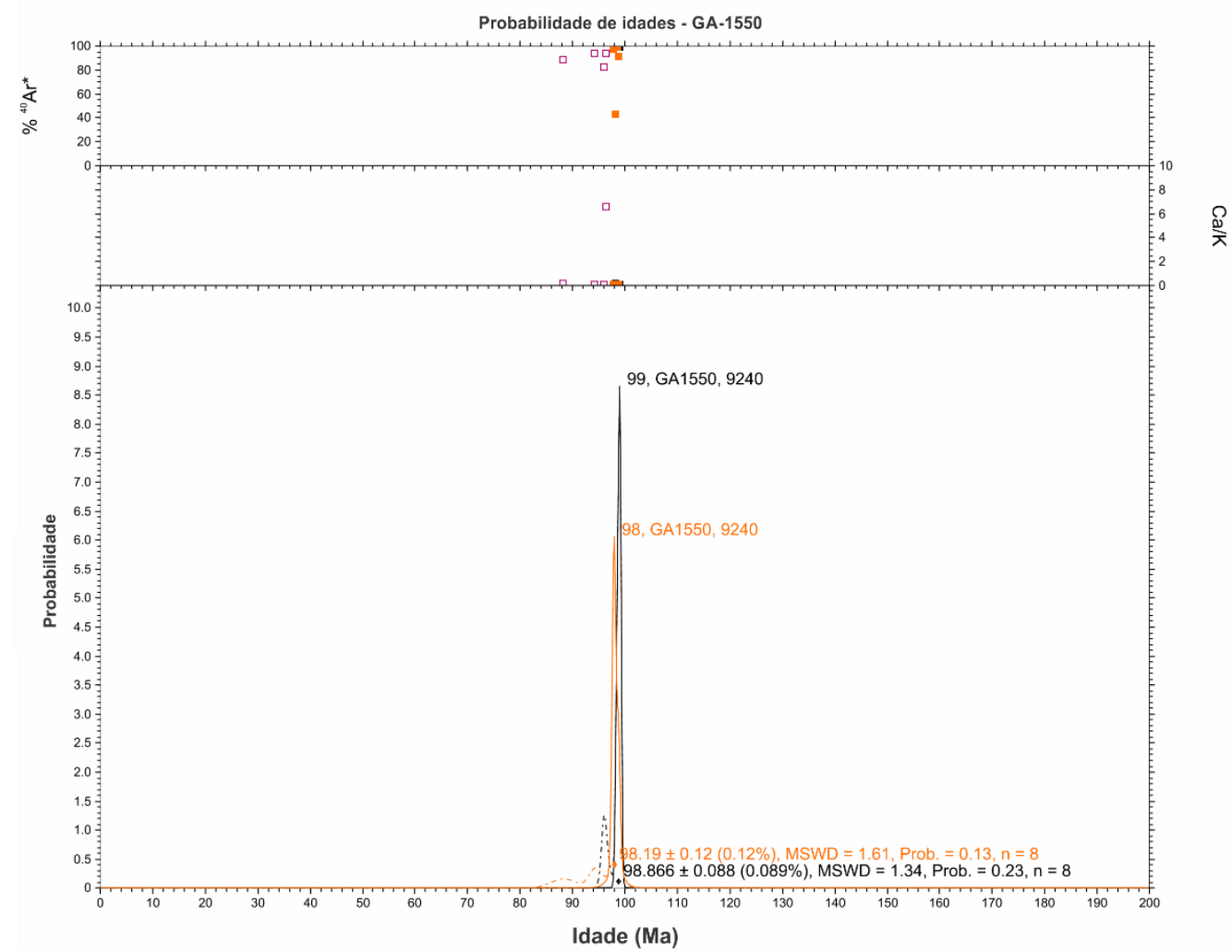

